Environmental Restoration Division

ORNL Environmental Restoration Program

\title{
Groundwater Quality Monitoring Well Installation for Waste Area Grouping 4 at Oak Ridge National Laboratory, Oak Ridge, Tennessee
}

\author{
J. A. Mortimore \\ M. L. Ebers
}

Date Issued-September 1994

Prepared for

U.S. Department of Energy

Office of Environmental Restoration and Waste Management under budget and reporting code EW 20

Environmental Restoration and Waste Management Programs Oak Ridge National Laboratory

Oak Ridge, Tennessee 37831-6285 managed by

MARTIN MARIETTA ENERGY SYSTEMS, INC.

for the

U.S. DEPARTMENT OF ENERGY

under contract DE-AC05-84OR21400 


\section{Author Affiliations}

J. A. Mortimore is staff project manager with the Environmental Restoration Program, Oak Ridge National Laboratory, Martin Marietta Energy Systems, Incorporated. M. L. Ebers is a senior hydrogeologist with Ogden Environmental and Energy Services Co., Inc. (formally ERC Environmental and Energy Services Company). 


\section{DISCLAIMER}

This report was prepared as an account of work sponsored by an agency of the United States Government. Neither the United States Government nor any agency thereof, nor any of their employees, make any warranty, express or implied, or assumes any legal liability or responsibility for the accuracy, completeness, or usefulness of any information, apparatus, product, or process disclosed, or represents that its use would not infringe privately owned rights. Reference herein to any specific commercial product, process, or service by trade name, trademark, manufacturer, or otherwise does not necessarily constitute or imply its endorsement, recommendation, or favoring by the United States Government or any agency thereof. The views and opinions of authors expressed herein do not necessarily state or reflect those of the United States Government or any agency thereof. 


\section{DISCLAIMER}

Portions of this document may be illegible in electronic image products. Images are produced from the best available original document. 


\section{CONTENTS}

EXECUTIVE SUMMARY $\ldots \ldots \ldots \ldots \ldots \ldots \ldots \ldots \ldots \ldots \ldots \ldots \ldots$

1. INTRODUCTION $\ldots \ldots \ldots \ldots \ldots \ldots \ldots \ldots \ldots \ldots \ldots \ldots \ldots \ldots \ldots \ldots \ldots \ldots \ldots$

1.1 THE WAG CONCEPT $\ldots \ldots \ldots \ldots \ldots \ldots \ldots \ldots \ldots \ldots \ldots \ldots \ldots \ldots \ldots \ldots$

1.2 DESCRIPTION OF WAG $4 \ldots \ldots \ldots \ldots \ldots \ldots \ldots \ldots \ldots \ldots \ldots \ldots$

2. INSTALLATION METHODS $\ldots \ldots \ldots \ldots \ldots \ldots \ldots \ldots \ldots \ldots \ldots \ldots$

2.1 A. L. CLARK DRILLING SERVICES DRILLING AND

INSTALLATION METHODS $\ldots \ldots \ldots \ldots \ldots \ldots \ldots \ldots \ldots \ldots, 3$

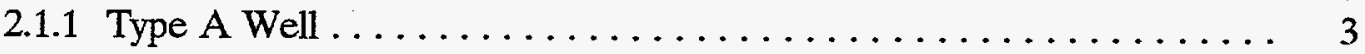

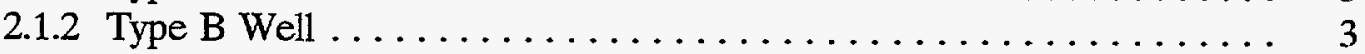

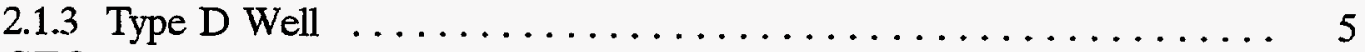

2.2 GEOTEK ENGINEERING DRILLING AND

INSTALLATION METHODS $\ldots \ldots \ldots \ldots \ldots \ldots \ldots \ldots \ldots, 5$

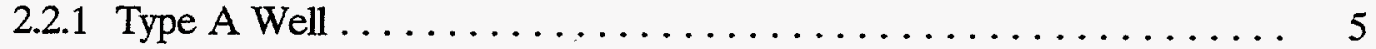

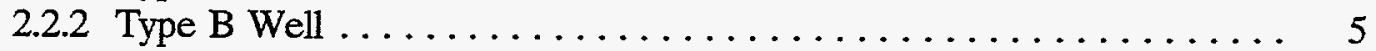

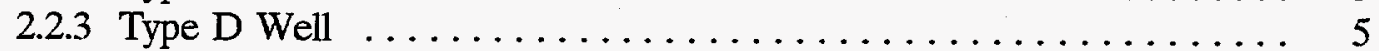

3. ENVIRONMENTAL, HEALTH, AND SAFETY REQUIREMENTS $\ldots \ldots \quad 7$

4. FIELD SUPPORT $\ldots \ldots \ldots \ldots \ldots \ldots \ldots \ldots \ldots \ldots \ldots \ldots \ldots \ldots \ldots$

5. DRILLING RECORDS $\ldots \ldots \ldots \ldots \ldots \ldots \ldots \ldots \ldots \ldots \ldots \ldots \ldots \ldots$

6. WELL DEVELOPMENT $\ldots \ldots \ldots \ldots \ldots \ldots \ldots \ldots \ldots \ldots \ldots \ldots \ldots \ldots$

7. SAMPLING DURING INSTALLATION $\ldots \ldots \ldots \ldots \ldots \ldots \ldots \ldots \ldots \ldots$

8. SPECIAL NOTES ON INSTALLATION AND DEVELOPMENT $\ldots \ldots \ldots 12$

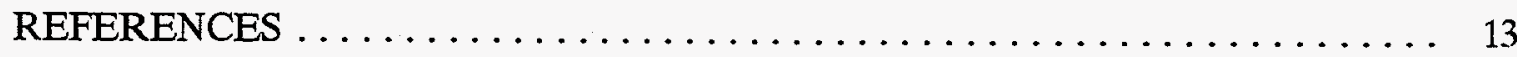

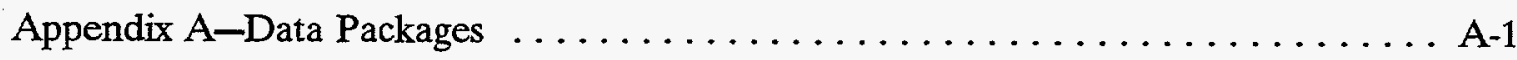

Appendix B-Operating Instructions for Handling Water and Cuttings from Well Drilling and Development of Groundwater Quality Monitoring Wells... 
-

-

- 



\section{INTRODUCTION}

The purpose of this report is to document the drilling and installation of the groundwater quality monitoring (GQM) wells on the perimeter of Waste Area Grouping (WAG) 4. Installation of GQM wells was required at Oak Ridge National Laboratory (ORNL) for regulatory compliance. Data obtained from these wells will be used to characterize and assess groundwater quality at the perimeter of each WAG in accordance with applicable Department of Energy, state, and Environmental Protection Agency regulatory requirements. The first four wells in WAG 4 were drilled by A. L. Clark Drilling Services during the period from September 1987 to November 1987. Eleven additional wells were drilled by Geotek Engineering Co. from September 1989 to April 1990. These 15 wells were developed from May 1990 to October 1990.

\subsection{THE WAG CONCEPT}

At ORNL, the solid waste management units (SWMUs) include solid waste storage areas (SWSAs), pipelines, spill sites, buildings, ponds, and experimental test sites that are considered to be potential sources of contamination. The SWMUs are further grouped into WAGs, the boundaries of which are defined by watersheds that contain contaminants derived from similar assemblages of operating facilities and SWMUs. Basically, the wells are located on or near these boundaries to determine whether contaminants have been released from the WAGs.

\subsection{DESCRIPTION OF WAG 4}

WAG 4 consists of about 27 acres located in Melton Valley approximately $2700 \mathrm{ft}$ southwest of the ORNL main plant area [Fig. 1, map pocket (MMES maps \#C3D20004A119, Rev. 0 and C3D20004A120, Rev. 0)]. It contains three inactive SWMUs: (1) the abandoned intermediate level liquid waste (ILLW) transfer line located along the WAG's northwestern boundary, (2) the experimental pilot pit area, and (3) SWSA 4, the largest unit in the WAG.

The ILLW transfer lines were used to transport fission waste products from the main plant area to the pits and trenches (WAG 1) for disposal. The lines were constructed of 2 -in.-diam cast-iron pipe and were buried about $3 \mathrm{ft}$ deep. The lines were decommissioned over a 2-year period beginning in 1981.

The experimental pilot pit area contains two pits that were to be used in studying means of fixing radioactive waste. Contaminated materials were removed from the site.

SWSA 4 is an elongated, irregular-shaped tract that trends northeast to southwest. It is bounded by White Oak Creek (WOC) to the east, Lagoon Road to the northwest, a reservation access road to the west, and an unnamed tributary to WOC to the southeast. The site was opened to waste disposal in 1951 and received a variety of low-level radioactive solid wastes and some hazardous chemical waste. The waste was disposed of in both auger holes 
and trenches excavated in the soil and weathered shale underlying the site. SWSA 4 was closed to radioactive and chemical waste in 1959 but continued to receive uncontaminated construction debris as a surface cap until 1973. Fifteen wells were installed along the perimeter of WAG 4 (Fig. 1, map pocket). 


\section{INSTALLATION METHODS}

Two separate drilling contractors drilled and installed the GQM wells in WAG 4. A.L. Clark drilled 4 wells in 1987, and Geotek drilled 11 wells in 1989 and 1990. The drilling and installation methods used by A.L. Clark varied slightly from those methods used by Geotek.

Four basic types of well construction were used during the GQM installation program at ORNL. Schematic diagrams of these four well types are shown on Fig. 2. Three of the four types (A, B, and D) were used at WAG 4. These types are described in Sects. 2.1 and 2.2. The specific details of each well installation are included in the monitoring well narratives (Appendix A). The specifications for drilling and well installation were provided in Construction Specifications for Monitoring Wells Installation Construction Project, K4491G-G1. ${ }^{1}$ The proposed well design criteria for the WAG 4 wells can be found in Preliminary Geohydrologic Site Characterization and Proposed Water Quality Well Locations for WAGs 4, 5, 3, and SWSA 1, ORNL/RAP/Sub-86/72139/1. ${ }^{2}$ Actual completion data for WAG 4 are listed in Table 1.

\subsection{A. L CLARK DRILLING SERVICES DRILIING AND INSTALLATION METHODS}

A.L. Clark drilled monitor wells 950 through 953 in 1987. Three types of GQM wells were installed in WAG 4 during this period. The three well types and the procedures that $A$. L. Clark Drilling Services employed to drill and install each type are discussed in detail in Sects. 2.1.1 through 2.1.3.

\subsubsection{Type A Well}

The type A well boring is drilled to total depth with 7-in. solid-stem augers. On completion, the boring is bailed with a steel bailer to remove drill cuttings. The well is completed with 2 -in. stainless steel screen, casing, and a silt trap. Stainless steel centralizers are positioned at the base and the top of the screen and every $20 \mathrm{ft}$ along the casing. A sandpack is poured into the annular space from total depth to $1 \mathrm{ft}$ above the screen. Pelleted bentonite is poured into the annular space to create a 2 -ft seal above the sandpack. The top of the bentonite seal is measured with a stainless steel weighted tape. The annular space above the bentonite seal is then grouted through a tremie pipe to the surface.

\subsection{Type B Well}

The first step in drilling the type B well is to auger a 14-in-diam boring from the surface to approximately $1 \mathrm{ft}$ into solid rock. A 10-in.-diam string of steel casing is installed in the boring, and the annulus is grouted to the surface. The boring is then deepened with an 8-in. tricone air rotary bit to total depth. The well is then completed with 4-in. stainless steel screen and casing. A sandpack, a bentonite seal, and grout are installed in the annular space by the same procedures as used for the Type A well. 


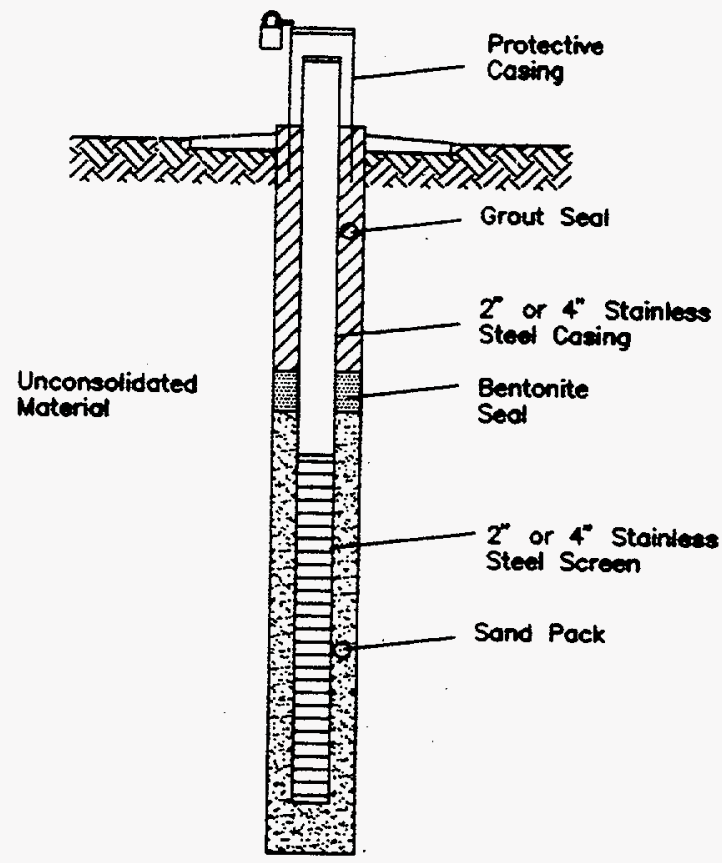

TYPE A WELL

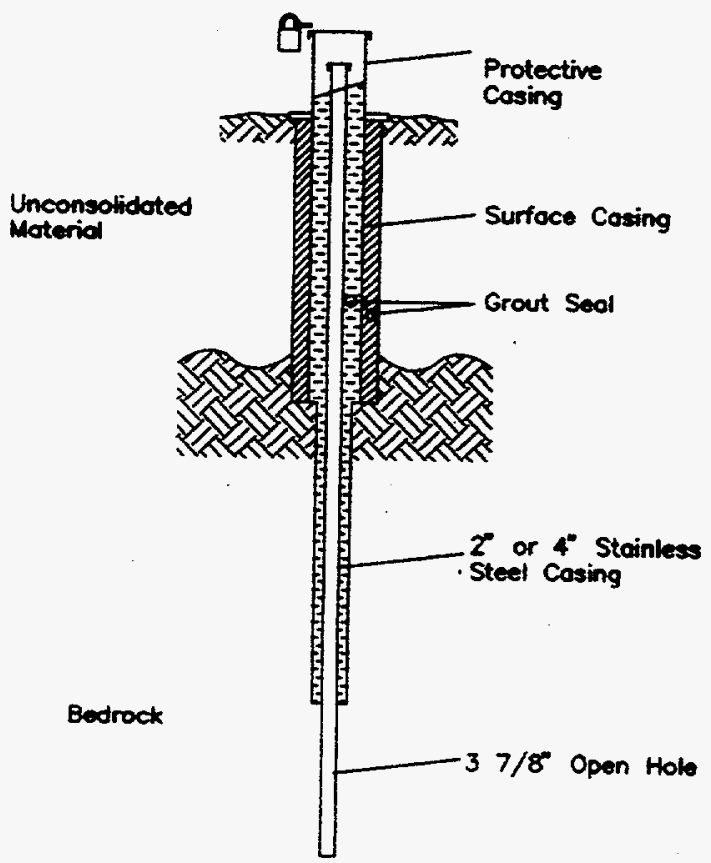

TYPE C WELL

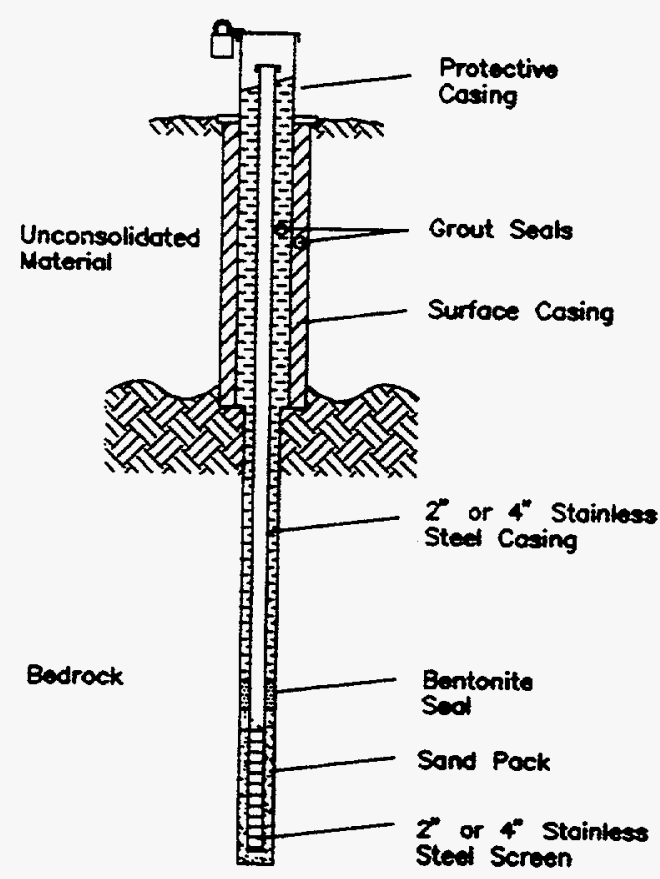

TYPE B WEL

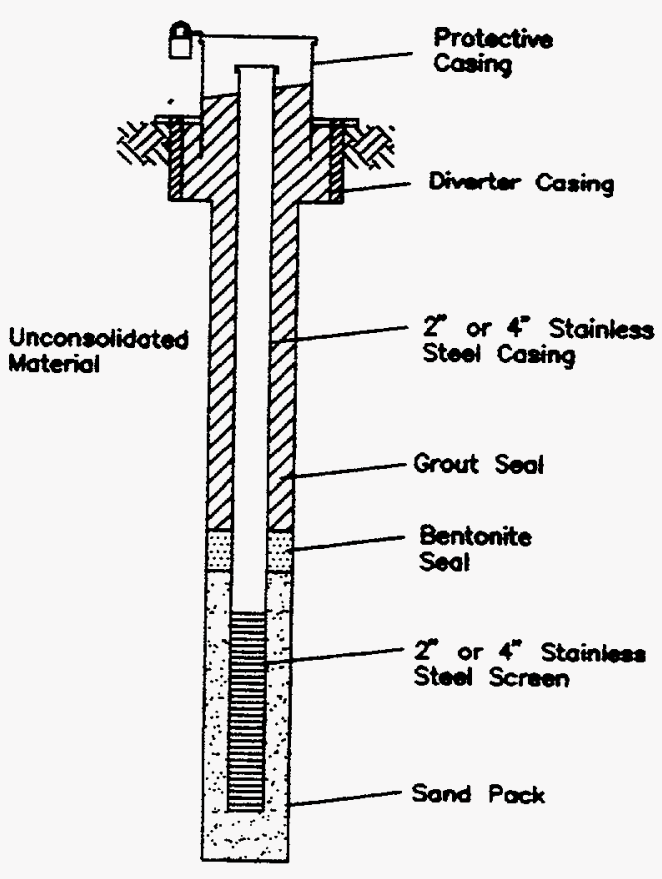

TYPE D WELL

Fig. 2. The four types of well construction used during the Groundwater Quality Monitoring Well Installation Program at Oak Ridge National Laboratory. 


\subsubsection{Type D Well}

The first step in drilling a type $D$ well is to auger a 12 -in. boring from the surface to approximately $1 \mathrm{ft}$ into solid rock. An 8-in-diam string of steel casing is installed in the boring and grouted to the surface. The boring is then deepened with a six-in. tricone air rotary bit to total depth. The well is then completed with 2 -in. stainless steel screen and casing. A sandpack, bentonite seal, and grout are installed in the annular space using the same procedures as in the type A well.

\subsection{GEOTEK ENGINEERING DRILLING AND INSTALLATION METHODS}

Geotek drilled wells 948, 949, and 954 through 962 during 1989 and 1990 . Three types of GQM wells were installed in WAG 4 during this period. The three well types and the procedures Geotek employed to drill and install each type are discussed in Sects. 2.2.1 through 2.2.3.

\subsubsection{Type A Well}

The type A well boring is drilled to total depth with 7-in.-diam solid stem augers. On completion, the boring is bailed with a steel bailer to remove drill cuttings. The well is completed with 2 -in.-diam stainless steel screen, casing, and silt trap. Stainless steel centralizers are positioned at the base and top of the screen and every $20 \mathrm{ft}$ along the casing. A sandpack is tremied into the annular space from total depth to $1 \mathrm{ft}$ above the screen. Pelleted bentonite is poured into the annular space to create a 2 - $\mathrm{ft}$ seal above the sandpack. The top of the bentonite seal is measured with a stainless steel weighted tape. The annular space above the bentonite seal is then grouted through a tremie pipe to the surface.

\subsubsection{Type B Well}

The first step in drilling a type B well is to auger a 22-in.-diam boring from the surface to 10 feet deep or auger refusal. A 15.25-in.-diam steel diverter casing is installed, and the annulus is grouted to the surface. The boring is then deepened with a 14.5-in.-diam tricone air rotary bit to a minimum of $2 \mathrm{ft}$ into bedrock. Next, a 10.75-in.-diam steel surface casing is installed and grouted into place. The air rotary method is used to drill an 8-in.-diam boring to total depth. The boring is completed with 4 -in.-diam stainless steel screen and casing. A sandpack, bentonite seal, and grout are installed in the annular space using the same procedures as those for the type A well.

\subsubsection{Type D Well}

A type $\mathrm{D}$ well is a converted type $\mathrm{A}$ well. If the 7-in.-diam auger encounters refusal before total depth on a type A well, the boring is reamed with a 22-in.-diam auger to refusal and a 15.25-in.-diam steel diverter is installed. The annulus is then grouted to the surface. The boring is deepened with a 6-in.-diam tricone air rotary bit to total depth, and the well is completed with 2 -in.-diam stainless steel screen and casing. Sandpack, bentonite seal, and grout are installed in the annular space using the same procedures as those for the type A well. 
6

Table 1. Actual completion data for WAG 4

\begin{tabular}{lccccc}
\hline Well & $\begin{array}{c}\text { Depth } \\
\text { clean to } \\
(\mathrm{ft})^{6}\end{array}$ & $\begin{array}{c}\text { SST } \\
\text { casing } \\
\text { diam } \\
\text { (in.) }\end{array}$ & $\begin{array}{c}\text { Well } \\
\text { type }\end{array}$ & $\begin{array}{c}\text { Screened } \\
\text { interval (ft) }\end{array}$ & $\begin{array}{c}\text { Water } \\
\text { level } \\
(\mathrm{ft})^{6}\end{array}$ \\
\hline 948 & 82.37 & 4 & B & $62.1-82.1$ & -13.9 \\
949 & 33.38 & 2 & D & $17.20-33.14$ & -7.8 \\
950 & 49.0 & 2 & A & $28.7-48.7$ & -1.2 \\
951 & 70.3 & 4 & B & $49.1-69.9$ & +1.2 \\
952 & 30.5 & 2 & A & $5.3-30.3$ & +3.1 \\
953 & 69.9 & 4 & B & $49.6-69.6$ & +2.7 \\
954 & 61.9 & 4 & B & $41.7-61.7$ & -2.3 \\
955 & 22.4 & 2 & D & $12.2-22.2$ & -6.4 \\
956 & 22.5 & 2 & D & $12.3-22.3$ & -3.8 \\
957 & 82.2 & 4 & B & $52.0-82.0$ & -1.0 \\
958 & 27.3 & 2 & D & $12.1-27.1$ & -4.5 \\
959 & 72.1 & 4 & B & $51.9-71.9$ & -4.5 \\
960 & 32.5 & 2 & D & $17.2-32.2$ & -8.1 \\
961 & 80.3 & 4 & B & $60.0-80.0$ & -17.8 \\
962 & 37.18 & 2 & A & $26.6-36.94$ & -8.5 \\
\hline
\end{tabular}

${ }^{a}$ Total drilled depth may vary from clean-out depth. See data packages (Appendix A)

${ }^{b}$ Predevelopment water level; depth measured from ground surface. (Negative is below surface; positive, above surface.) 


\section{ENVIRONMENTAL, HEALTH, AND SAFETY REQUIREMENTS}

All well drilling at WAG 4 was conducted in accordance with procedures outlined in Health, Safety, and Environmental Protection Procedures for Excavating Operations, ORNL/M$116 / \mathrm{R}^{3}$. Among the procedures set forth by this document is a system for rating proposed well locations according to the degree of possibility that contamination will be encountered. Ratings obtained by this system were used to determine the level of personnel training required and health and safety coverage to be used during drilling.

The Superfund Amendment Reauthorization Act required still more stringent health and safety measures for personnel working in waste areas. These workers were required to have $40 \mathrm{~h}$ of training for hazardous duty through an ORNL-approved course, $8 \mathrm{~h}$ of refresher training each year, $8 \mathrm{~h}$ of supervisor's training for field supervisors, a whole-body count, baseline urinalysis, respirator testing and fitting, and medical monitoring. Personnel were also required to take a construction-worker training course covering the fundamentals of radioactivity and other types of contamination as well as the other hazards that could be encountered at ORNL. The workers were taught the proper procedures to follow in the event of an on-site emergency.

Special procedures were used during drilling. The ground surface at all drill sites was covered with polyethylene sheeting to prevent contact between the tools and the ground. The sheeting would also have protected the environment in the event of a hydraulic fluid release. Containment was required for all drill cuttings produced. During augering, a metal pan was used to hold cuttings until a health physicist (HP) could determine their proper disposition. During air rotary drilling, cuttings were diverted from the borehole to a special containment box designed by Martin Marietta Energy Systems, Inc. (Energy Systems). The box is a 500-gal, trailer-mounted tank with demister elements and high-efficiency particulate air filters at the air exhaust. In order that appropriate methods of disposal could be determined, the tank contents were checked by the HP for radioactive contamination and by the site hydrogeologist for volatile organics. The operating instructions that were followed for determining disposition of the cuttings and water produced during drilling and development are included in Appendix B. 


\section{FIELD SUPPORT}

The GQM wells in WAG 4 were installed by the construction contractors A.L. Clark Drilling Services and Geotek Engineering Company during the period from September 1987 to April 1990.

ORNL Engineering administered the drilling contract through Energy Systems Procurement. The management organization chart for the project can be found in the report Task Management Plan for Groundwater Quality Monitoring Well Installation, ORNL/RAP/LTR-88/28. ${ }^{4}$

The hydrogeologic support and installation record keeping were supplied through a contract with ERC Environmental and Energy Services Company (ERCE). An ERCE representative was present during all activities that affected the quality of the wells and advised Energy Systems on well construction. ORNL personnel or their subcontractors provided HP and industrial hygiene support.

Construction engineering support was supplied by Energy Systems personnel. Drawings, excavation permits, well placement in the field, and as-built surveying and calculations were done by the Energy Systems Civil and Architectural Department or by their subcontractor, Adams Craft Herz Walker Engineering Company. The as-built survey coordinates and elevations are on the well installation/completion form for each well (Appendix A). The as-built coordinates are also summarized in a table on the well location maps (Fig. 1). 


\section{DRILLING RECORDS}

A complete data package has been compiled for each of the $15 \mathrm{GQM}$ wells drilled in WAG 4. These data packages are presented in numerical order in Appendix A. All original records are retained in the Environmental Restoration (ER) Division Records Control Data Base. The forms included in each well data package are listed here in the order in which they appear in the package:

1. monitor well narrative,

2. predrilling checklist for monitoring wells,

3. decontamination checklist for drilling equipment,

4. well $\log$,

5. well installation/completion form,

6. monitoring well materials certification,

7. post-well completion checklist,

8. monitoring well development form,

9. monitoring well development progress,

10. hydraulic conductivity calculation,

11. nonconformance report (if necessary), and

12. chain of custody forms.

Three additional forms used in the field by the site hydrogeologist but not included in the published data packages are the monitoring well progress form, the hydraulic conductivity test field sheet, and the containment box checklist. These forms are kept in the ER Division Records Control Data Base. 


\section{WELL DEVELOPMENT}

Wells were developed by pumping. Wells with high initial turbidities were surged beforehand with a workover rig and a stainless steel surge block to facilitate removal of the sediment from the wells. The contents of the wells were then pumped out using Geoguard airlift pumps and oilless air compressors. Development of a well was considered complete when at least three well volumes had been removed and the turbidity was measured at 5 NTUs or less. Several wells had turbidity ratings higher than 5 NTUs even after extensive pumping, but, in order to prevent the pulling in of groundwater from too far away, a maximum limit of 30 to 35 well volumes was determined by Energy Systems hydrogeologists to be the upper limit that should be removed. The contents of the wells were pumped out using Geoguard development pumps. The two-stage Geoguard pumps were converted to dedicated bladder pumps for sampling after development was complete. All development water was contained and disposed of according to the operating instructions in Appendix B.

Of the 15 wells in WAG 4, 14 had turbidities less than or equal to 5 NTUs. The number of well volumes removed ranged from 8.6 to 88.8 , with an average of 22.6 . The procedure for measuring turbidity described in ORNL/RAP/LTR-88/28 4 was replaced with a more accurate method. While the previously used method depended on a visual comparison of the sample with prepared standards, the new method employs the Cole-Parmer turbidimeter, which measures NTUs by passing a lens-focused light beam through a test tube filled with a water sample. A photosensor detects the intensity of the exiting light beam, and an analog scale on the instrument displays the turbidity of the sample. 


\section{SAMPLING DURING INSTALLATION}

The ERCE hydrogeologist took samples of soil, rock, and drilling water during well installation and submitted them to the ORNL Analytical Chemistry Division for chemical analyses. Soil and rock samples were taken from the unsaturated and saturated zones. Samples of drilling water were collected from the water pump discharge on the drill rig during air rotary drilling. All samples were transferred using chain-of-custody forms, which are included in the data packages. The sampling procedures are explained in the report ORNL/RAP/LTR-88/28. ${ }^{4}$ Soil samples were collected from each single well and from one well of each well pair. A drilling-water sample was collected from each air-rotary-drilled boring.

Analyses for 31 chemical elements, gross alpha, gross beta, and ${ }^{40} \mathrm{~K}$ were routinely performed on the soil and water samples. The results from these analyses are contained in the ER Division Records Control Data Base. 


\section{SPECIAL NOTES ON INSTALLATION AND DEVELOPMENT}

During the drilling of the GQM wells in WAG 4, several events occurred in which contamination was detected.

- A rotten organic odor was detected during the installation of the casing in well 948.

- Radioactivity contamination of $2 \mathrm{mR} / \mathrm{h}$ was detected in the auger cuttings at $0.5 \mathrm{in}$. during the augering of well 954 from $0.0 \mathrm{ft}$ to $13.5 \mathrm{ft}$. During the grouting of well 954 , volatile organic readings of from 20 to $65 \mathrm{ppm}$ were recorded. Volatile organic readings of from 100 to $1000 \mathrm{ppm}$ were recorded in the head space in the barrels containing well development water.

- Readings of $10,000 \mathrm{cpm}$ (radioactivity) were taken in the auger cuttings at $0.5 \mathrm{in}$. during augering from $0.0 \mathrm{ft}$ to $9.5 \mathrm{ft}$ in well 955 . Volatile organic readings over $1000 \mathrm{ppm}$ were taken in the head space in the barrels containing well development water from well 955. A predevelopment water sample showed $8000 \mathrm{~Bq} / \mathrm{L}$ of tritium.

- Organic volatile readings of from 30 to $45 \mathrm{ppm}$ were recorded in the well bore from $0.0 \mathrm{ft}$ to $13.5 \mathrm{ft}$ in well 956. During the cleaning out of the boring at $22.5 \mathrm{ft}$, a hole blew out of the ground $20 \mathrm{ft}$ from the well. A strong sewer-gas odor was noticed, and volatile organic readings over $100 \mathrm{ppm}$ were recorded. Volatile organic readings over $100 \mathrm{ppm}$ were taken in the head space in the barrels containing well development water from well 956.

- Volatile organic readings of from 100 to $1000 \mathrm{ppm}$ were detected in the head space in the barrels containing well development water in well 957. A predevelopment water sample indicated $88,000 \mathrm{~Bq} / \mathrm{L}$ of tritium.

- A predevelopment water sample indicated 99,000 Bq/L tritium in well 958 . 


\section{REFERENCES}

1. Engineering Division, Construction Specifications for Monitoring Wells Installation Construction Project, K-4491G-G1 (Rev. 2), Martin Marietta Energy Systems, Inc., Oak Ridge National Laboratory, Oak Ridge, Tenn., August 1988.

2. MCI Consulting Engineers, Inc., Preliminary Geohydrologic Site Characterization and Proposed Water Quality Well Locations for WAG 4, 5, 3, and SWSA 1, ORNL/RAP/Sub-86/72139/1, Martin Marietta Energy Systems, Inc., Oak Ridge National Laboratory, Oak Ridge, Tenn., February 1987.

3. Environmental Compliance and Health Protection Division, Health, Safety, and Environmental Protection Procedures for Excavating Operations, ORNL/M-116/R1, Martin Marietta Energy Systems, Inc., Oak Ridge National Laboratory, Oak Ridge, Tenn., March 3, 1988.

4. J. A. Mortimore, Task Management Plan for Groundwater Quality Monitoring Well Installation, ORNL/RAP/LTR-88/28, Martin Marietta Energy Systems, Inc., Oak Ridge National Laboratory, Oak Ridge, Tenn., February 1988. 
Appendix A

Data Packages 
1.0 General Information

\subsection{Well Location}

Monitoring well number 948 is located in WAG 4 . It is located on the west side of WAG 4 approximately $150^{\prime}$ south of the intersection of Chemical Waste Area Road and Lagoon Road. The location is shown on ORNL drawing number C3E20004A075. Survey coordinates for this well are $N$ $18,959.2548, \mathrm{E} 27,001.4340$ (X-10 grid) or latitude $35^{\circ}$, $54^{\prime}, 48.39^{\prime \prime}$ and longitude $84^{\circ}, 19^{\prime}, 20.92^{\prime \prime}$. Coordinate data were provided by Martin Marietta Energy Systems. The method used for conversion from $x-10$ grid to TennesseeLambert state Plane coordinates came from the publication "Tennessee Valley Authority Data Services Branch and Mapping Services Branch, Oak Ridge, Tennessee, DOE Plant Control, November 6, 1985, Field Book: ESS-3115, pp. 120." The latitude and longitude were calculated by Adams Craft Herz walker Engineering, Inc., using methods from the U.S. Coast and Geodetic Survey Publication 62-4, "State Plane Coordinates by Automatic Data Processing."

\subsection{Driling Information}

Well number 948 was drilled by Geotek Engineering Company. $A$ Mobile B-50 and an Ingersoll Rand $\mathrm{T}-4$ rig were used to drill this boring for monitor well installation under the operation of Rick Herron and Larry Ledbetter with the assistance of James Shelton and Fred Dixon. Drilling commenced on $9 / 26 / 89$ and was finished on 10/12/89. Paragraph 2.4.1 includes a detailed discussion of the well installation and a well schematic is included on the well installation/completion form. A synopsis of the drilling 
activity follows. This information was typed directly from field notes and was edited only when necessary for clarification.

9/26/89: The Mobile B-50 auger rig was decontaminated and mobilized to the site and set up. The boring was split spooned and augered to 19.0 ' with 8" hollow stem augers. The boring was reamed from $0.0^{\prime}$ to $7.0^{\prime}$ with $22^{\prime \prime}$ augers and a diverter casing set and grouted in.

10/4/89: The Ingersoll Rand $T-4$ was steam cleaned and mobilized to the well location.

10/5/89: The boring was deepened from $7.0^{\prime}$ ' to $15.0^{\prime}$ with 14" augers and drilled to $21.0^{\prime}$ with a tricone air rotary bit. A $20.6^{\prime}$ joint of $103 / 4^{\prime \prime}$ surface casing was placed in the boring.

10/6/89: The surface casing was grouted in.

10/11/89: The Ingersoll Rand $\mathrm{T}-4$ was steam cleaned.

10/12/89: The rig was mobilized to the well location and setup. An $8^{\prime \prime}$ tricone was used to deepen the boring from $21.0^{\prime}$ to 83.0 '. Boring produced 8 ' of water at $60^{\circ}$ in 10 minutes and $25^{\prime}$ water at $83^{\circ}$ in 10 minutes. Completed well at $83^{\prime}$ with 4" stainless steel screen casing, sand and bentonite. Drillers noticed a rotten organic odor from boring while installing casing. Photovac readings of containment box were $1000+$ ppm. Containment box was allowed to aerate then checked and ok'ed by MMES Industrial Hygiene.

10/13/89: Annular space in well was grouted.

10/17/89: The well was tested with the "GO-No GO" gauge and passed by R.C. Williams. 
This well was logged by ERC Environmental and Energy Services Co., Inc., hydrogeologist Michael L. Ebers and $C$. Allison Hodges. All well construction materials and supplies were from Martin Marietta Energy Systems approved batches. The batch origin of individual items is shown on the included Monitoring Well Materials Certification form.

2.0 Technical Information

\subsection{Decontamination Procedures}

The drilling rig, down hole tools, surface casing, stainless steel screen, stainless steel casing, centralizers, and stainless steel silt trap underwent the cleaning decontamination procedures outlined in the drilling specifications (Release specific Technical Directions for Regulatory Compliance Monitoring Wells Phase 1, Oak Ridge National Laboratory, Oak Ridge, W.O. K-4147, April 1987, pgs. 2-4). A checklist of the cleaned materials is included with this data package.

\subsection{Geology}

WAG 4 is located in Melton Valley which is in the Valley and Ridge Physiographic Province of East Tennessee. WAG 4 is underlain by shale, siltstone, and limestone of the Middle to Upper Cambrian Conasauga Group. The Conasauga Group in the oak Ridge area consists of six formations. They are, in ascending order, the Pumpkin Valley Shale, Rutledge Limestone, Rogersville Shale, Maryville Limestone, Nolichucky shale and the Maynardville Limestone. The Pumpkin Valley shale and Rutledge Limestone underlie WAG 4. 
strike in and near WAG 4 ranges from $N 85^{\circ} \mathrm{E}$ to $\mathrm{N} 15^{\circ} \mathrm{E}$ and dip varies from $27^{\circ}$ to vertical. These variations in strike and dip indicate that the conasauga has been deformed in the locale of WAG 4.

\section{3 sample Collection}

One soil sample was collected during drilling, placed in an I-CHEM specialty cleaned glass container, sealed and submitted to Sample Receiving, Analytical Chemistry Division, Bldg. 4500s, ORNL. A chain of custody form for this sample is included with this data package. Soil sample 948501 was collected in the augered interval from 16.0 feet to 19.0 feet on $9 / 26 / 89$. A drill water sample was collected from the water pump on the drill rig on $10 / 12 / 89$. Analytical results for the two samples described above can be obtained from the Remedial Action Program data base at ORNL.

A bulk density soil sample was collected from the split spoon sample interval from 4.4 to 4.7 feet. The sample was measured and weighed, and a bulk density of $2.0 \mathrm{grams} / \mathrm{cm}^{3}$ was calculated.

The Ingersoll-Rand T-4 compressed air was sampled with a cloth filter inserted between drill rods on october 12, 1989. The sample was examined with an ultraviolet light for the presence of hydrocarbons. The filter exhibited a dull fluorescence. 


\subsection{Installation and Development}

\subsubsection{Installation}

This was a Type B well. A 22.0-inch diameter boring was augered from ground surface to 7.0 feet. A 15 1/4-inch diverter casing was installed from surface to 7.0 feet below ground surface and grouted in place. A 14.0-inch diameter boring was augered from 7.0 feet to 15.0 feet (auger refusal). The boring was then extended past the refusal depth with a 14.0-inch air rotary tricone roller bit from 15.0 feet to 21.0 feet. A 10 3/4-inch diameter string of decontaminated steel surface casing was installed from 0.0 feet to 21.0 feet, sealed with a 3.4-foot bentonite pellet layer from 17.6 feet to 21.0 feet, and tremie grouted in place. The surface casing minimizes potential cross contamination between the regolith and bedrock water bearing zones. After the surface casing was installed, the air rotary method was used to drill an 8inch diameter boring to a total depth of 83.0 feet. A 4inch diameter stainless steel silt trap was installed from 82.10 feet to 82.37 feet. Above the silt trap, a 4-inch diameter stainless steel screen was installed from 62.1 feet to 82.1 feet. A 4-inch diameter stainless steel casing was installed from the top of the screen at 62.1 feet and extended 2.3 feet above ground surface. A sandpack was then tremied into the annular space from 59.4 to 82.37 feet, with a 2.6-foot bentonite pellet seal poured into the annular space above the sandpack from 56.8 to 59.4 feet. The annular space from the top of the bentonite seal to the surface was tremie grouted with a cement/bentonite slurry. A detailed schematic of the well is included on the well installation/completion form. 


\subsubsection{Well Development}

Well number 948 was developed to remove drill cuttings, silt, and other fines. The monitoring well was developed using a Geoguard pump with an air compressor. All pumps were cleaned prior to use according to specified cleaning procedures (see Paragraph 2.1). The well was developed until a measured total of 1155 gallons of water had been evacuated and the clarity of the discharge water was approved by the company representative. The final turbidity value measured at completion was 4.0 NTU's. A development form showing the exact method of development and other pertinent data is appended.

\subsubsection{Installation of Dedicated Konitoring Well Pump}

After the well was developed, a Geoguard Model No. 5614 dedicated monitoring well pump was installed on June 13, 1990, at a depth of 80.6 feet below ground surface. These pumps are decontaminated at American Sigma and are sent prepackaged. A copy of the pump certification is kept on file at ORNL.

\subsection{Hydraulic Conductivity Testing}

Well number 948 was tested for the determination of hydraulic conductivity of the aquifer in the vicinity of the well screen. This was accomplished by instantaneously adding a known quantity of water to the monitoring well and measuring the recovery of the water level over time. The changing water levels were measured using a Druck 15 psi pressure transducer and an Omnidata Datapod II data recorder. The hydraulic conductivity value of $1.14 \times 10^{-5}$ 


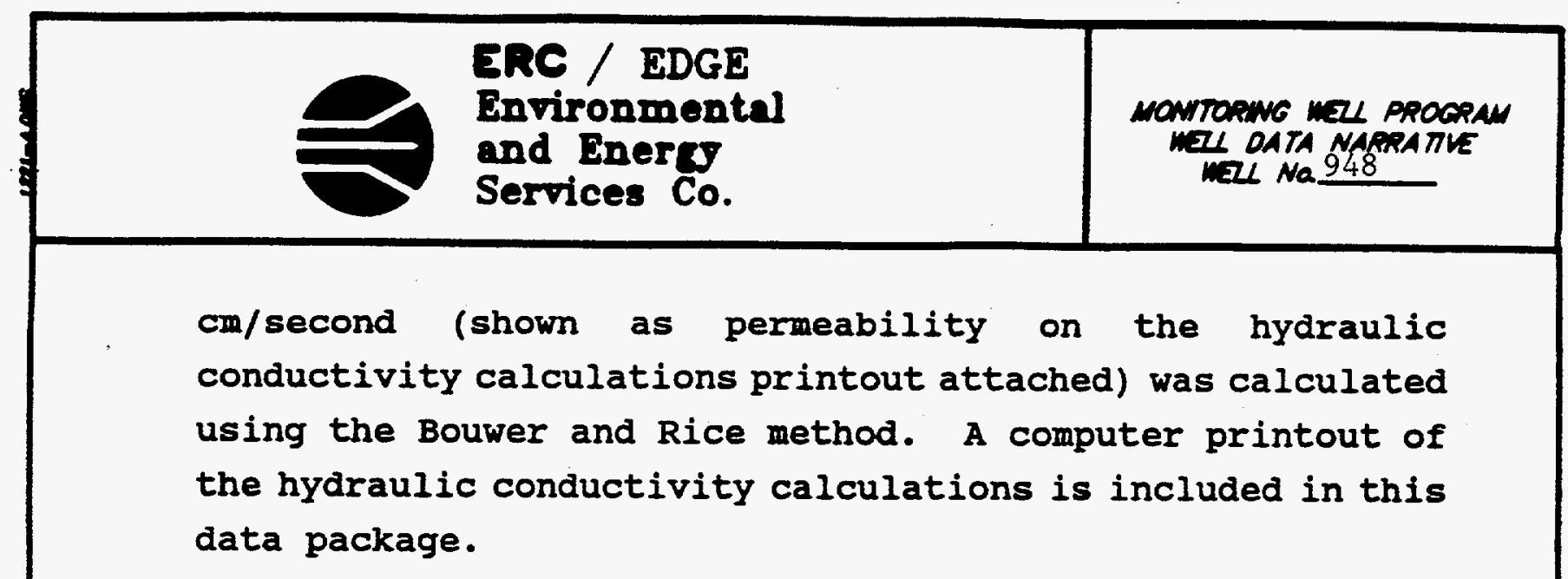

PACE 7 of 23 
ERC / EDGE

Environmental

and Energy

WELL NO. 948

\section{PRE-DRILLING CHECKLIST FOR MONITORING WELLS}

\section{PRE-DRILLING TASKS}

1. EXCAVTION PERMIT OBTAINED

2. ALL EQUIPMENT HAS BEEN CLEANED BEFORE DRILING.

30. SCREEN AND CASING HAVE BEEN WASHED, STEAMED, RINSED WTH DE-IONIZED OR DISTILLED WA TER, RINSED WTH ISOPROPK ALCOHOL, WRAPPED WIH PROTECTIVE COVERING AND STORED OFF THE GROUND.

36. PRE-PACKAGED SCREENS, CASING AND CENTRALIZERS WERE USED.

4. WORK AREA FOR SAMPLE EXAMINATION COVERED WTH CLEAN POL TETHIRENE.

5. CLEAN KNIVES, GLOVES, SAMPLE JARS AND LABELS ON HAND.

6. POLYETHIRENE COVER IN PLACE OVER HOLE.

7. AIR ROTARY COMPRESSED AIR SAMPLED.
COMPLIANCE

DATE

INITALS

9/26/89 CAH

$9 / 26 / 89$

CAH

$\mathrm{N} / \mathrm{A}$

CAH
$10 / 12 / 89$

lue

9/26/89 CAH

9/26/89 CAH

$9 / 26 / 89$

CAH

RESUL TS:

ADDITONAL NOTES/OBSERVATONS:

$-$

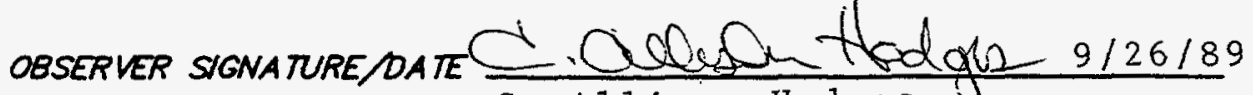
Sft. Allison Hogies $10 / 12 / 89$ 
ERC / EDGE

Environmental

and Energy

Services Co.

\section{DECONTAMINATION CHECKLIST DRILLING EQUIPMENT}

\begin{tabular}{|c|c|c|c|c|c|}
\hline EQUIPMENT & SCRAPE & $\begin{array}{l}\text { STEAN } \\
\text { CLEAN }\end{array}$ & $\begin{array}{l}\text { STEAM } \\
\text { RINSE }\end{array}$ & $\begin{array}{c}\text { ISOPROPY } \\
\text { ALCOHOL } \\
\text { RINSE }\end{array}$ & $\begin{array}{c}\text { OEIONIZED } \\
\text { WATER } \\
\text { RINSE }\end{array}$ \\
\hline$R / G$ & $\mathrm{x}$ & $\mathrm{X}$ & $\mathrm{X}$ & $N / A$ & $N / A$ \\
\hline AUGERS & $\mathrm{X}$ & $\mathrm{X}$ & $\mathrm{X}$ & $\mathrm{X}$ & $\mathrm{X}$ \\
\hline$B / T 5$ & $\mathrm{x}$ & $\mathrm{X}$ & $\mathrm{X}$ & $\mathrm{x}$ & $\mathrm{x}$ \\
\hline RODS & $x$ & $\mathrm{x}$ & $\mathrm{X}$ & $\mathrm{X}$ & $X$ \\
\hline SAMPLERS & $\mathrm{x}$ & $\mathrm{X}$ & $\mathrm{X}$ & $\mathrm{x}$ & $x$ \\
\hline PIPES & $x$ & $x$ & $x$ & $\mathrm{x}$ & X \\
\hline WORK TOOLS & $\mathrm{X}$ & $X$ & $\mathrm{X}$ & $\mathrm{X}$ & $\mathrm{X}$ \\
\hline AUGER PINS & $\mathrm{X}$ & $\mathrm{x}$ & $\mathrm{X}$ & $\mathrm{x}$ & $\mathrm{X}$ \\
\hline & . & & & & \\
\hline & & & & & \\
\hline & & & & & \\
\hline
\end{tabular}

\section{OBSERVER SIGNATURE/DATE C. Clecusuntodges 9/26/89 C. Allison Hodges}




\section{ERC / EDGE
Environmental
and Energy
Services Co.}

ORNL MONITORING WELL LOG

LOCA TON: WAG4

ORILLER: Rick Herron/Larry Ledbetter

HELPER: James Shelton/Fred Dixon

ORILL: Mobile B-50/Ingersoll Rand T-4

THPE DRILLNG: Split spoon, augering, Air No. SAMPLES TAKEN: Roty one (948S01)

CONTAINMENT TYPE: Auger pan, plastic, containment box

THICKNESS OF SOLL (REFUSAL DEPTH): 19.0

DEPTH DRILLEO IN ROCK:

64.0

TOTAL OEPTH OF WELL:

83.0
ORILLNG FLUID SAMPLES:

TPE:Dri11 WaterDATE: $10 / 12 / 89$

(948W01)

\begin{tabular}{|c|c|c|c|c|}
\hline \multicolumn{2}{|c|}{$\begin{array}{c}\text { DEPTH } \\
\text { (FEET) }\end{array}$} & \multirow{2}{*}{$\begin{array}{l}\text { SAMPLE } \\
\text { (NUMBER \& } \\
\text { INTERVAL) }\end{array}$} & \multirow{2}{*}{$\begin{array}{c}\text { PERCENT } \\
\text { RECOVERY } \\
\text { (SPUT SPOONS) }\end{array}$} & \multirow{2}{*}{ SOL/BEDROCK DESCRIPTION } \\
\hline & & & & \\
\hline 0.0 & 2.5 & & & Gravel fill material (RAD) \\
\hline \multirow[t]{4}{*}{2.5} & 2.8 & & $90 \%$ & Gravel, roots, fill material (RAD), clay, \\
\hline & & & & mottled, dark yellowish orange, light brown, \\
\hline & & & & silty, micaceous, slightly damp, firm (Fill \\
\hline & & & & material) \\
\hline \multirow[t]{6}{*}{3.2} & 4.5 & & $80 \%$ & Clay, shaley, mottled (in layers), dark \\
\hline & & & & yellowish orange, light brown with pale olive \\
\hline & & & & and grayish green lenses that are silty, whole \\
\hline & & & & sample micaceous; scattered brittle shale \\
\hline & & & & fragments, dusky brown, moist. Bulk density \\
\hline & & & & a $4.4^{\prime}$ to $4.7^{\prime}=2.0$ grams $/ \mathrm{cm}^{3}$ \\
\hline \multirow[t]{4}{*}{4.5} & 5.5 & & $40 \%$ & Shale, clayey, thinly laminated, light olive \\
\hline & & & & brown, dusky yellow, silty; with hard shale \\
\hline & & & & fragments (layers), dusky brown, crumbly, dry \\
\hline & & & & but will hold form \\
\hline \multirow[t]{2}{*}{5.5} & 6.75 & & $100 \%$ & Shale, clayey, thinly laminated, light olive \\
\hline & & & & brown and dusky yellow, very silty, damp \\
\hline 6.75 & 7.5 & & & Augered, shale, clayey, light olive brown, damp \\
\hline \multirow[t]{3}{*}{7.5} & 8.2 & & $50 \%$ & Shale, slightly clayey, breaks at $45^{\circ}$, light \\
\hline & & & & olive gray, with pale greenish to yellowish \\
\hline & & & & \\
\hline
\end{tabular}




\begin{tabular}{|c|c|c|c|c|}
\hline & & & $\begin{array}{l}\text { SRe / E } \\
\text { Bnvironn } \\
\text { and Iner } \\
\text { Servicen }\end{array}$ & $\begin{array}{l}\text { DDGE } \\
\text { nental } \\
\text { rog } \\
\text { Co. }\end{array}$ \\
\hline & ORNL & MONITORING & WELL LOG & PACS 2 of 2 \\
\hline$\frac{\text { OEP }}{\text { (FEZ }}$ & & $\begin{array}{l}\text { SAMPLE } \\
\text { (NUMESR } \\
\text { INTERVAL) }\end{array}$ & $\begin{array}{c}\text { PERCENT } \\
\text { RECOVERY } \\
\text { (SPUT SPOCNS) }\end{array}$ & SOL BEDROCK DESCRIPION \\
\hline & & & & gray clay lenses that are silty, thinly \\
\hline & & & & laminated, crumbly, slightly damp \\
\hline & 08.2 & & & Split spoon refusal \\
\hline 8.2 & 10.5 & & & Shale, light olive gray, crumbly, slightly damp \\
\hline 10.5 & 13.0 & & & Siltstone, calcareous, medium dark gray, brittle \\
\hline & & & & medium hard augering \\
\hline 13.0 & 16.5 & & & Shale, olive gray, soft \\
\hline 16.5 & 19.0 & $\begin{array}{r}9485010^{0} \\
16.0^{\prime}-19.0^{\prime} \\
\end{array}$ & & Limestone, medium dark gray $\&$ shale, olive gray \\
\hline & a19.d & & & Auger refusal \\
\hline 19.0 & 21.0 & & & *Slow, hard drilling, limestone? \\
\hline 21.0 & 47.0 & & & Soft, easy drilling, hard streaks at $37^{\prime}$ and $41^{\prime}$ \\
\hline 47.0 & 50.0 & & & Alternating fairly hard and soft drilling \\
\hline 50.0 & 63.0 & & & Soft, easy drilling \\
\hline 63.0 & 66.0 & & & Fairly hard drilling \\
\hline 66.0 & 83.0 & & & Soft, easy drilling \\
\hline & 83.0 & & & Total Depth. \\
\hline & & & & * Lithologic description not available from \\
\hline & & & & $19.0^{\prime}$ to $83.0^{\prime}$ T.D. due to the use of a \\
\hline & & & & containment box. \\
\hline & & & & \\
\hline & & & & \\
\hline & & & & \\
\hline & & & & \\
\hline & & & & \\
\hline & & & & \\
\hline & & & & \\
\hline & & & & \\
\hline & & & & \\
\hline & & & & \\
\hline & & & & \\
\hline & & & & \\
\hline & & & & \\
\hline
\end{tabular}




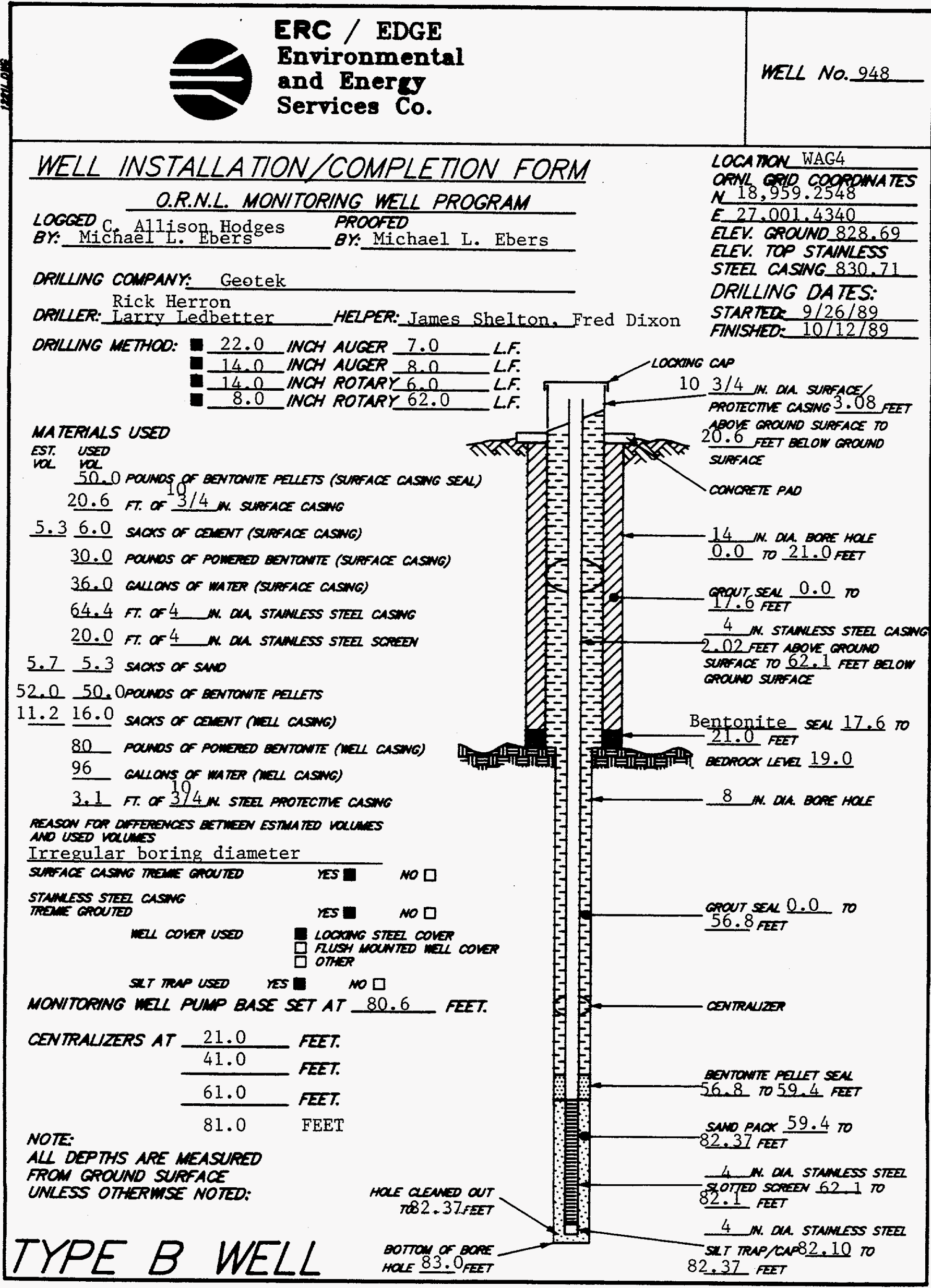

PACE 12 or 23 
ERC / EDGE

Environmental

WELL NO. .948

and Energy

Services Co.

DATE: $10 / 12 / 89$

\section{MONITORING WELL MATERIALS \\ CERTIFICATION}

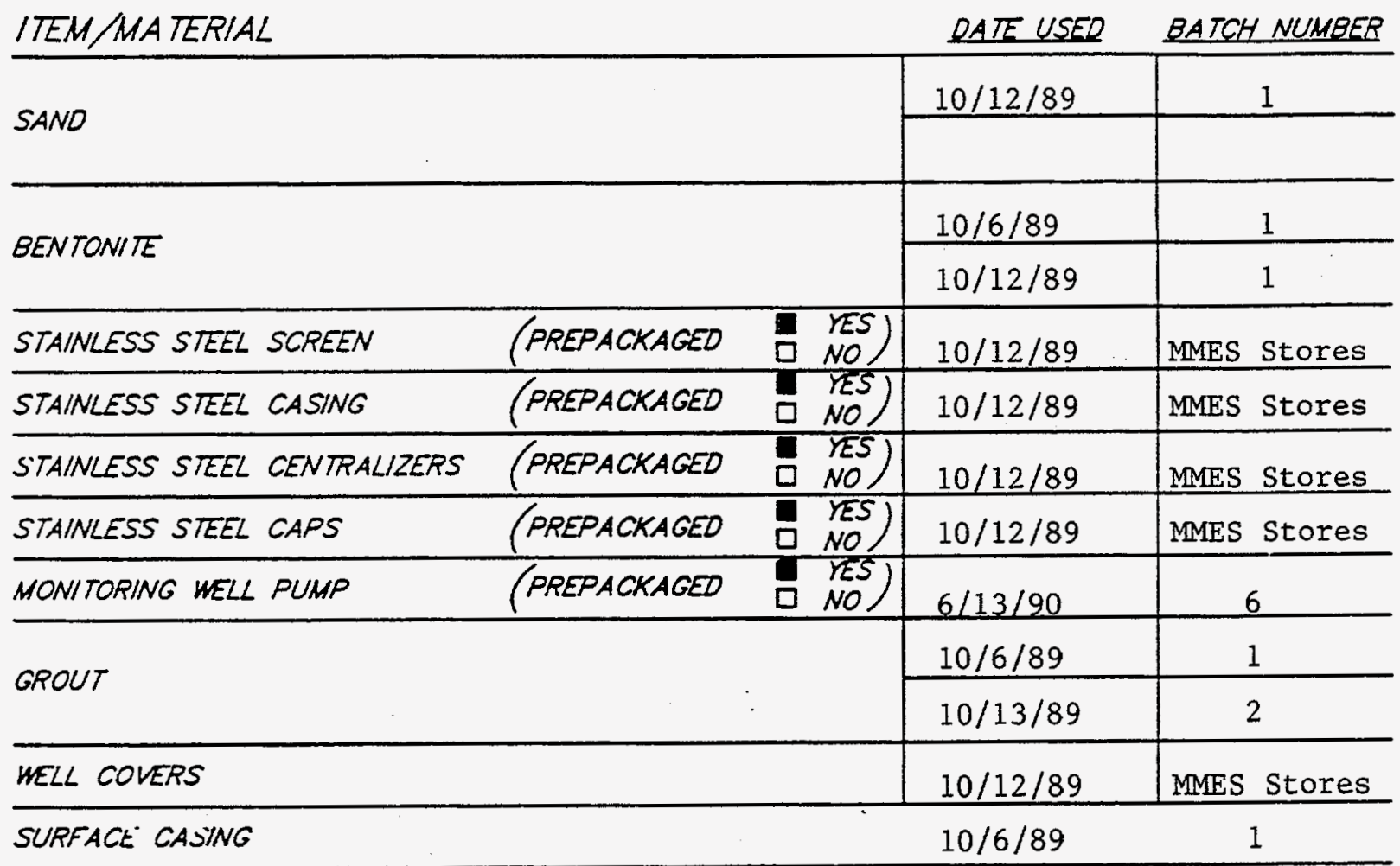

COMMENTS:

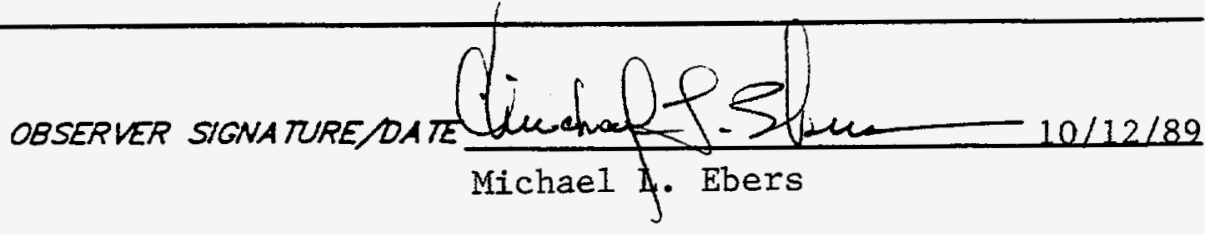

PAGE 13 OF 23. 


\begin{tabular}{|c|l|}
\hline $\begin{array}{l}\text { ERC / EDGE } \\
\text { Environmental } \\
\text { and Energo } \\
\text { Services Co. }\end{array}$ & WELL No. 948 \\
\hline & $\frac{\text { POST-WELL COMPLETION }}{C H E C K L I S T}$ \\
\hline
\end{tabular}

\section{POST-MELL COMPLETION TASKS}

$$
\begin{aligned}
& \text { COMPLIANCE } \\
& \text { QA.E INITALS }
\end{aligned}
$$
1. WUO SCRAPED FRON AUGERS SAMPLERS ANO ALL
OTHER EQUIPWENT.

10/12/89 MLE

2. ALL WUD FRON RIG ANO EQUIPNENT SCRAPINGS MO OUTTNOS OISPOSED OF IN ACCORDANCE WTH THE SPECACA IION PROWOED.

3. WEL OEVEZORED IN ACCOROANCE MITH THE SPECATCA HON PROMOED ANO OETAKS OF IHE DEVELOPWENT ACHUTY RECOROED.

4. DRKLNG STE PROPERL Y CLEANED UP AFTER COMPLETION OF MEI INSTALIATON.

$10 / 12 / 89 \quad \mu L E$

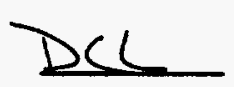

10/13/89 HLE

- REZEASE SPECATC TECANCAL DIRECTONS FOR REGULATORY COMPUANCE MONITORANG WELLS PHASE I. OAK RIDGE NATIONAL LABORATORY, OAK RIOEE W. K-4147, APRK 1987.

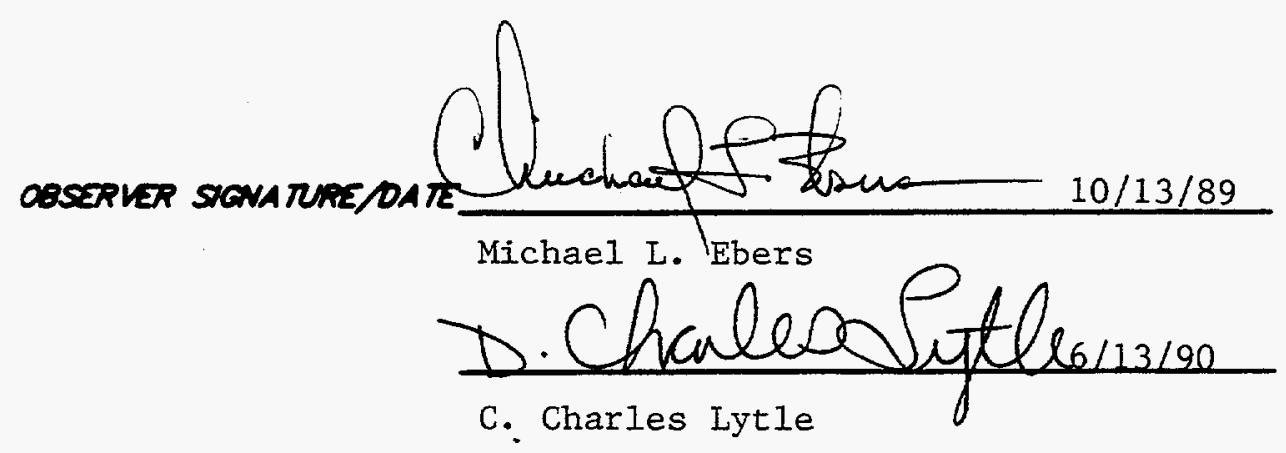




\section{ERCE}

Environmental

and Energy

Services Co.

\section{MONITORING WELL \\ DEVELOPMENT FORM}

DEVELOPMENT DETAILS

METHOD OF

DEVELOPMENT: Surging and pumping

DEYELOPMENT

BEGAN DATE:

$5-24-90$

TME:

DEVELOPMENT

ENDING DATE:

$6 / 13 / 90$

DEVELOPMENT

OBSERVED BY: D. Charles Lytle

ONE WELL VOLUME: 60.5

GALLONS

TOTAL GALLONS PUMPED: 1155 TOTAL WELL VOLUNES PUMPED: 19.1

INITAL PH: 7.5 FNAL PH: 8.2

INITAL CONDUCTUTY ( $(\mathrm{S} / \mathrm{cm}): 635$ FNAL CONDUCTUTY $(\mu \mathrm{s} / \mathrm{cm}): 679$

OESCRIPTIN OF INITAL RURBIDITY: Slight1y cloudy

DESCRIPTION OF FINAL TURBIDITY: Clear

FNAL MEASURED TURBIDITY:

$4.0 \mathrm{NTU}^{\prime} \mathrm{s}$

WELL APPROVED BY: R.C. Wiliams MMES

ODOR

OE MATER:

None

WA TER

DISCHARGED

GROUND SURFACE

TO:

Q STORM SEWERS

Q DRUNS

Q TANK TRUCK
G STORAGE TANKS
Q OTHER

INITAL PRE-DEVELOPMENT

WATER DEPTH: 13.9 feet from ground surface

\section{DEVELOPMENT OBSERVATIONS}

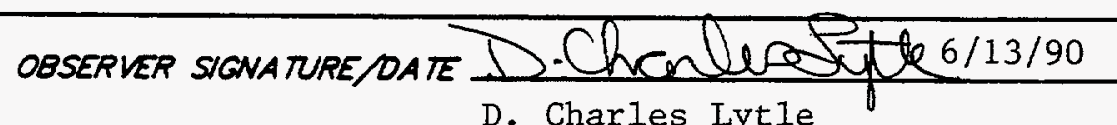

D. Charles Lytle 


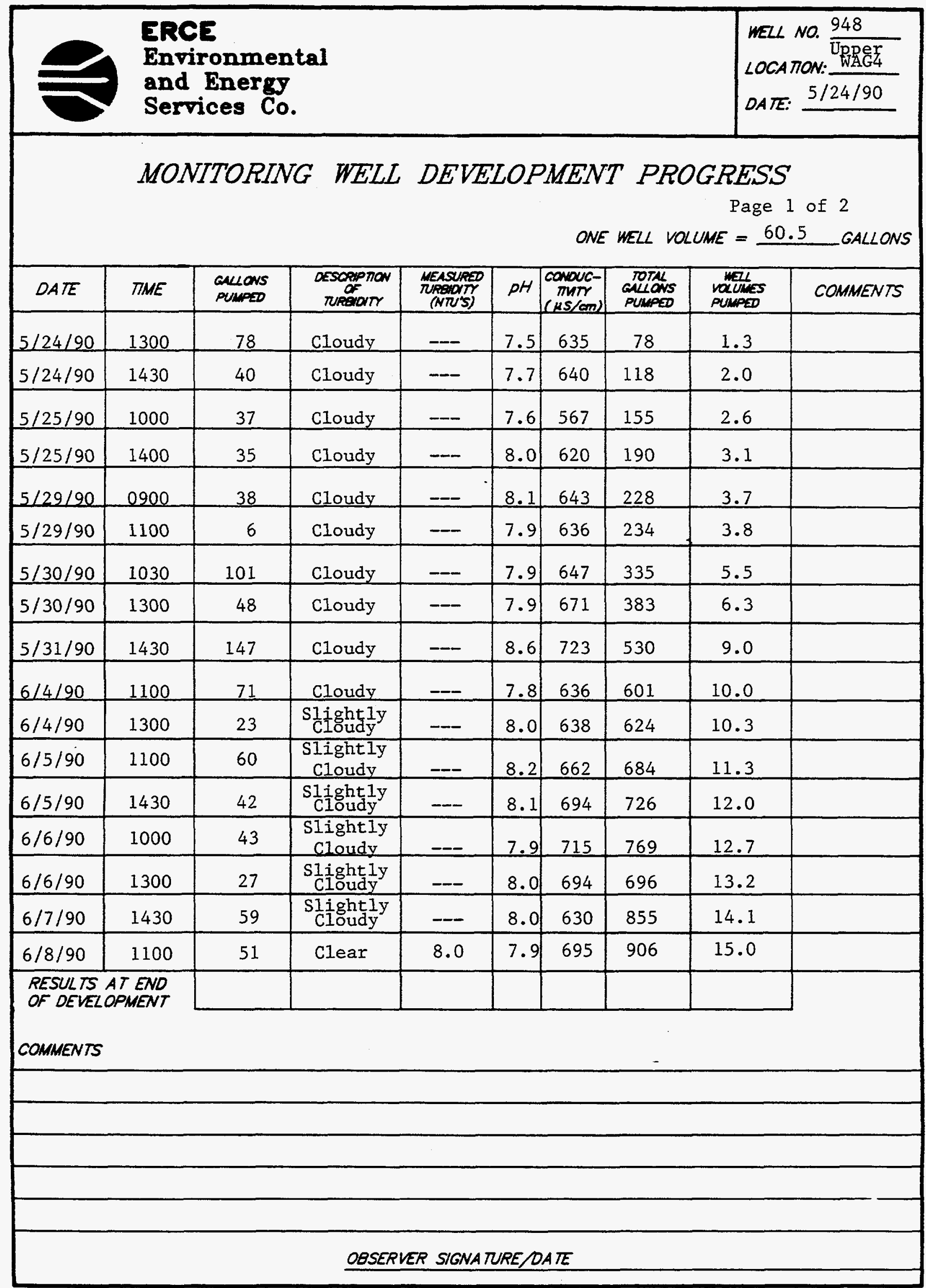




\section{MONITORING WELL DEVELOPMENT PROGRESS}

Page 2 of 2

ONE WELL VOLUME $=60.5$

GALLONS

\begin{tabular}{|c|c|c|c|c|c|c|c|c|}
\hline$D A T E$ & TIME & $\begin{array}{l}\text { GanONS } \\
\text { PUNPED }\end{array}$ & 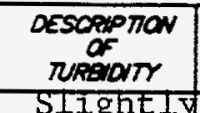 & $\begin{array}{l}\text { MEASUAED } \\
\text { TURBOWT } \\
\text { (NR'S) }\end{array}$ & $p H$ & $\begin{array}{l}\text { conbuc- } \\
\text { murr } \\
\text { (HS/On) }\end{array}$ & $\begin{array}{l}\text { FoTAL } \\
\text { aflows } \\
\text { PUAPED }\end{array}$ & $\begin{array}{l}\text { reukes } \\
\text { vaupes } \\
\text { punpeD }\end{array}$ \\
\hline $6 / 8 / 90$ & 1405 & 14 & Cloudy & -- & 8.0 & 692 & 920 & 15.2 \\
\hline $6 / 11 / 90$ & 1100 & 55 & $\begin{array}{l}\text { Slightly } \\
\text { Cloudy }\end{array}$ & $\cdots$ & 8.1 & 701 & 975 & 16.1 \\
\hline $6 / 11 / 90$ & 1410 & 58 & Slightly & -- & 8.0 & 674 & 1033 & 17.1 \\
\hline $6 / 12 / 90$ & 1105 & 40 & Clear & 9.0 & 8.0 & 690 & 1073 & 17.7 \\
\hline $6 / 12 / 90$ & 1500 & 25 & Clear & 6.0 & 7.8 & 720 & 1098 & 18.1 \\
\hline $6 / 13 / 90$ & 0930 & 40 & Clear & 6.0 & 8.5 & 677 & 1138 & 18.9 \\
\hline $6 / 13 / 90$ & 1100 & 17 & Clear & 4.0 & 8.2 & 679 & 1155 & 19.1 \\
\hline & & & & & & & & \\
\hline & & & & & & & & \\
\hline & & & & & & & & \\
\hline & & & & & & & & \\
\hline & & & & & & & & \\
\hline & & & & & & & & \\
\hline & & & & & & & & \\
\hline & & & & & & & & \\
\hline $\begin{array}{l}\text { RESUL TS } \\
\text { OF DEVEL }\end{array}$ & $\begin{array}{l}T E N D \\
\text { SMENT }\end{array}$ & & Clear & 4.0 & 8.2 & 679 & 1155 & 19.1 \\
\hline
\end{tabular}

COMMENTS

A good producer. This well took a long time to clear up made plenty of water but pumped slow. Passed with $4.0 \mathrm{NTU}^{\prime} \mathrm{s}$ and moved to another hole 


\title{
HYDRAULIC CONDUCTIVTY CALCULATIONS
}

\author{
PROGRAM SLUGT, VERSION 4.1, NOV. 1986
}

THIS PROGRAM CALCULATES MEAN TRANSMISSIVITIES FROM

SLUG-TEST DATA BASED ON TWO ANALYTICAL APPROACHES:

(1) METHOD OF COOPER, BREDEHOEFT AND PAPADOPULOS, 1967

(ARTICLE IN VOL.3, NO.1 OF WRR ENTITLED

"RESPONSE OF A FINITE DIAMETER WELL TO AN INSTANTANEOUS CHARGE OF WATER")

(2) METHOD OF BOUWER AND RICE, 1976 (ARTICLE IN

VOL. 12, NO.3 OF WRR ENTITLED

"A SLUG TEST FOR DETERMINING HYDRAULIC CONDUCTIVITY

OF UNCONFINED AQUIFERS WITH COMPIETELY OR PARTIALLY PENETRATING WELLS")

WELI NO.: 948

PROJECT NO.: E221-002

SITE LOCATION: WAG-4

EDGE, INC. FIELD INVESTIGATOR: JAMES W. CARUTHERS
DATE OF TEST: $10-30-90$

CLIENT: MMES

INPUT DATA ARE:

INNER CASING DIAMETER $=4.00$ INCHES

INNER SCREEN OR OPEN-HOLE DIAMETER $=4.00$ INCHES

DIAMETER OF DRILLED HOLE $=8.00$ INCHES

ILENGTH OF SCREEN OR INTAKE PORTION $=20.00$ FEET

DEPTH FROM STATIC LEVEL TO BOTTOM OF SCREEN $=64.90$ FEET

THICKNESS OF SATURATED AQUIFER ZONE $=20.00 \mathrm{FEET}$

DEPTH TO STATIC WATER LEVEI BELOW REF. POINT $=1.00$ FEET

ESTIMATED POROSITY OF GRAVEL PACK $=.20$

FALLING-HEAD INDEX $=1$ ("I" IF FALIING, "O" IF RISING)

NUMBER OF DEPTH-TIME DATA POINTS = 32

HO WAS COMPUTED FROM INTERCEPT OF PLOT OF LOG(H) VS. TIME

SUCCESSIVE COMPUTED

VALUES FOR HO

(FEET)

2.6837

2.6854 


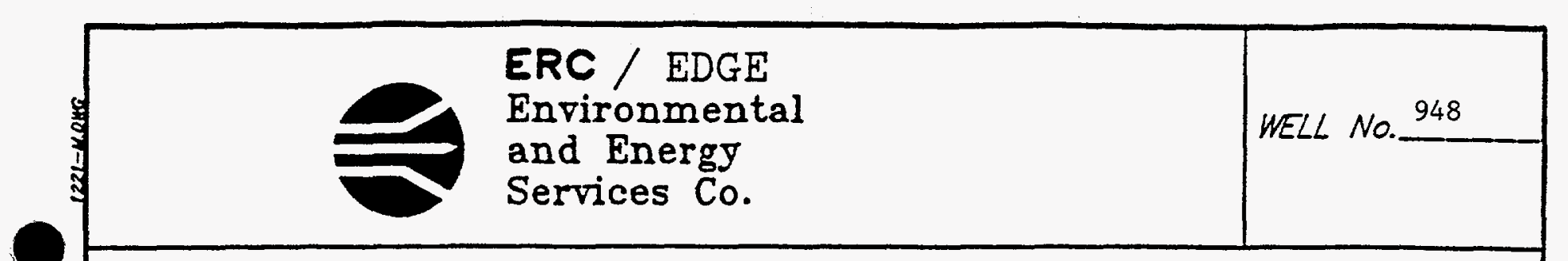

HYDRAULIC CONDUCTIVTY CALCULATTONS

\begin{tabular}{|c|c|c|}
\hline$\left(\operatorname{SEC}^{\text {TIME }}\right)$ & $\begin{array}{l}\text { DEPTH TO WATER } \\
\text { (FEET) }\end{array}$ & $\begin{array}{l}\text { HEAD } \\
\text { (FEET) }\end{array}$ \\
\hline $\begin{array}{r}10.00 \\
20.00 \\
30.00 \\
40.00 \\
50.00 \\
60.00 \\
75.00 \\
90.00 \\
105.00 \\
120.00 \\
150.00 \\
180.00 \\
240.00 \\
300.00 \\
360.00 \\
420.00 \\
480.00\end{array}$ & $\begin{array}{l}3.740 \\
3.730 \\
3.690 \\
3.690 \\
3.670 \\
3.670 \\
3.660 \\
3.640 \\
3.640 \\
3.640 \\
3.620 \\
3.600 \\
3.600 \\
3.580 \\
3.540 \\
3.530 \\
3.500\end{array}$ & $\begin{array}{l}2.740 \\
2.730 \\
2.690 \\
2.690 \\
2.670 \\
2.670 \\
2.660 \\
2.640 \\
2.640 \\
2.640 \\
2.620 \\
2.600 \\
2.600 \\
2.580 \\
2.540 \\
2.530 \\
2.500\end{array}$ \\
\hline $\begin{array}{r}540.00 \\
600.00 \\
720.00 \\
840.00 \\
960.00 \\
1080.00 \\
1200.00 \\
1320.00 \\
1440.00 \\
1560.00 \\
1680.00 \\
1800.00 \\
1920.00 \\
2040.00 \\
2160.00\end{array}$ & $\begin{array}{l}3.500 \\
3.430 \\
3.400 \\
3.360 \\
3.320 \\
3.290 \\
3.260 \\
3.210 \\
3.200 \\
3.170 \\
3.130 \\
3.100 \\
3.080 \\
3.040 \\
3.020\end{array}$ & $\begin{array}{l}2.500 \\
2.430 \\
2.400 \\
2.360 \\
2.320 \\
2.290 \\
2.260 \\
2.210 \\
2.200 \\
2.170 \\
2.130 \\
2.100 \\
2.080 \\
2.040 \\
2.020\end{array}$ \\
\hline
\end{tabular}




\title{
HYDRAULIC CONDUCTIVTY CALCULATIONS
}

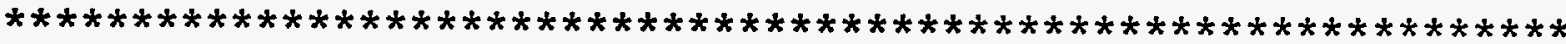 \\ METHOD OF BOUWER AND RICE \\ COMPUTED RESULTS USING DIAMETER OF DRILLED HOLE: \\ PERMEABILITY $=3.75 \mathrm{E}-07 \mathrm{FT} / \mathrm{SEC}=1.14 \mathrm{E}-05 \mathrm{CM} / \mathrm{SEC}$ \\ TRANSMISSIVITY $=7.50 \mathrm{E}-06 \mathrm{FT} * 2 / \mathrm{SEC}$
}

COMPUTED RESULTS USING DIAMETER OF CASING AND SCREEN:

PERMEABILITY $=4.33 \mathrm{E}-07 \mathrm{FT} / \mathrm{SEC} \quad=1.32 \mathrm{E}-05 \mathrm{cM} / \mathrm{SEC}$

TRANSMISSIVITY $=8.66 \mathrm{E}-06 \mathrm{FT} * 2 / \mathrm{SEC}$ 


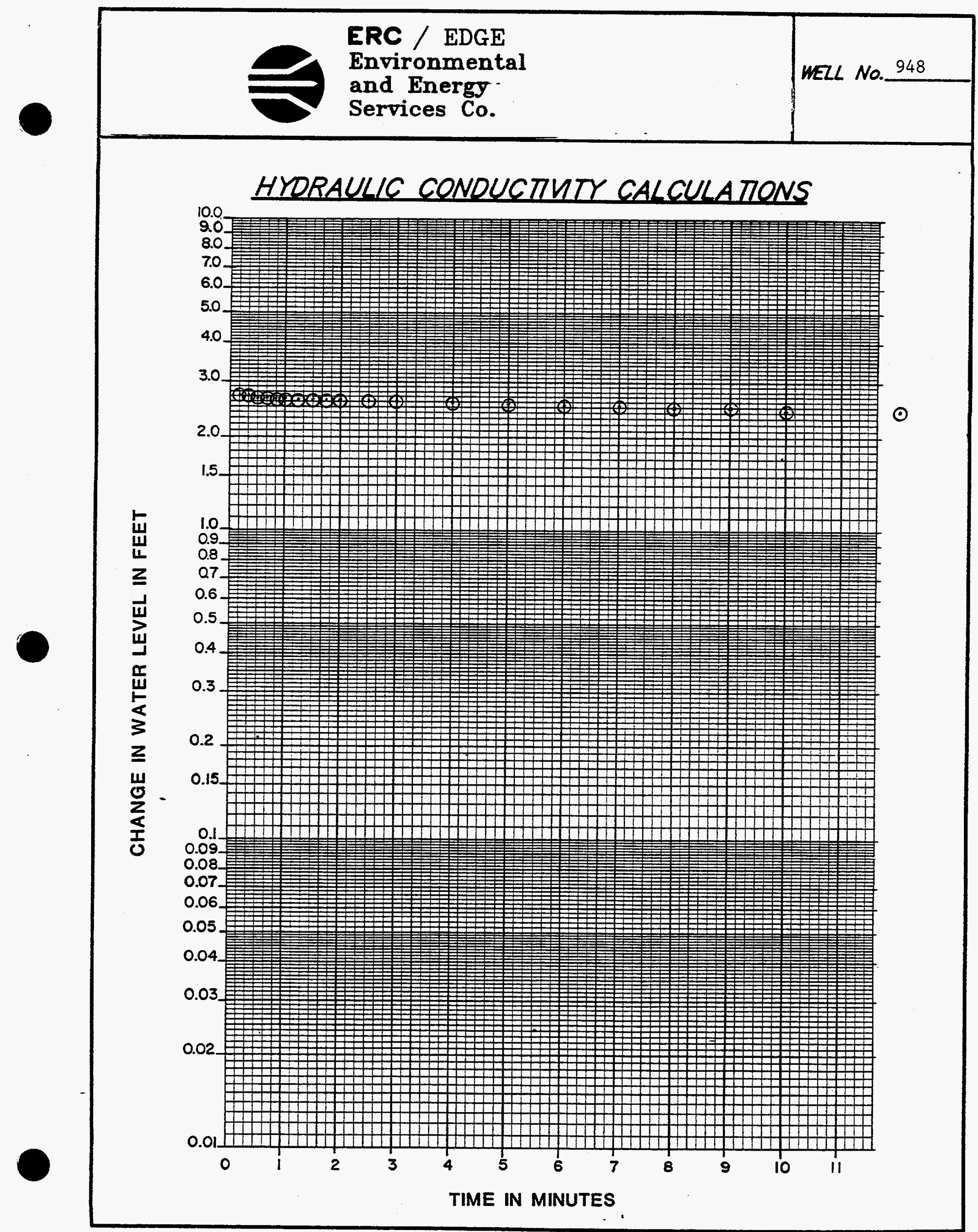

PACE 21 of 23 


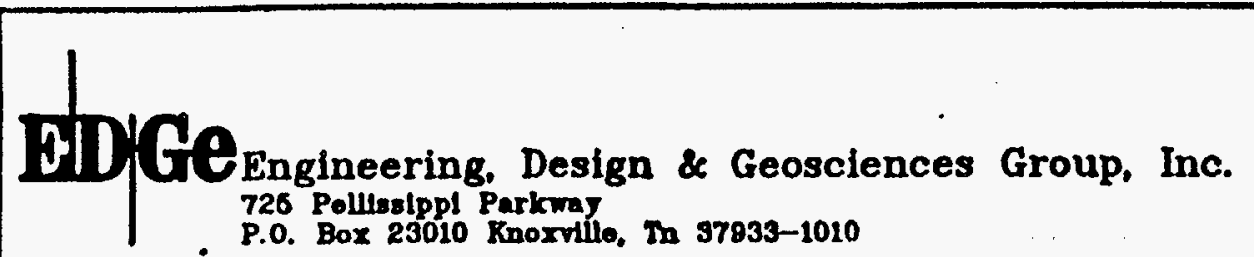
FOR

MARTIN MARIETTA ENERGY SYSTEMS OAK RIDGE NATIONAL LABORATORY

726 Pollusippl Parkway ilo, th s7933-1010
P.0. Box 23010 Knoxvilo,

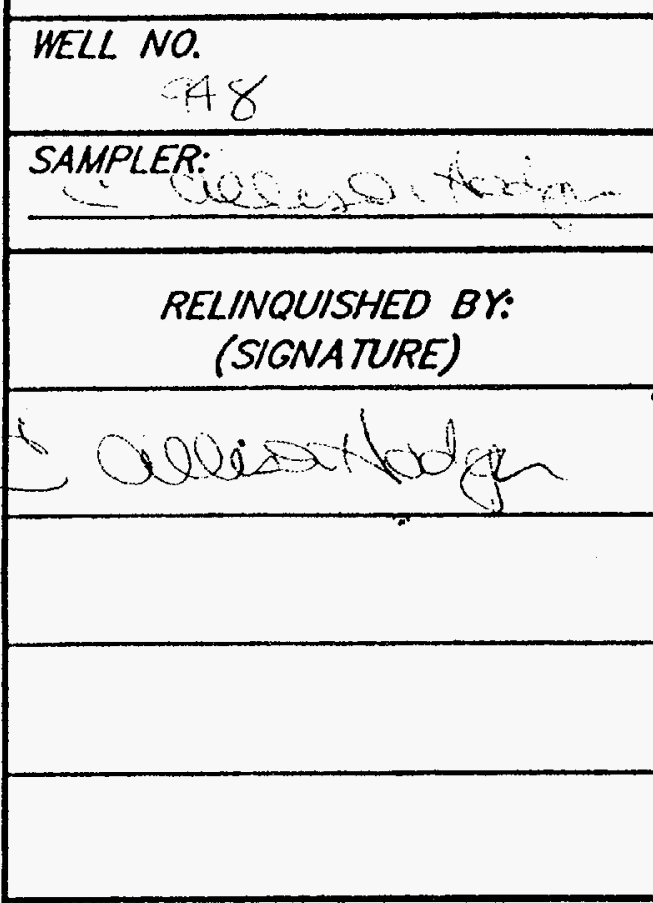

TMPE OF SAMPLE: D SPLIT SPOON CORES-SOIL 口 AIR ROTARY CUTINGS-ROCK

\begin{tabular}{|l|l|l} 
& & \\
\hline & & \\
& & \\
\hline
\end{tabular}

\section{LOCATION:} N) SAMPLE INTERVAL:

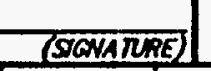

\begin{tabular}{l|l|l|l}
\hline DATE: & TME: & . WTH: & RECEIVED BY:
\end{tabular}

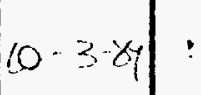
(SIGNATURE)

4 TYPE:

\begin{tabular}{|c|c|}
\hline DATE: \\
$9-26,89$ & TME:
\end{tabular}

$-$

1

D AUGER CUTTNGS-SOIL

$\square$ DRILL WATER (NO AIR IN SAMPLE)

ALL SAMPLES ARE IMMEDIA TELY PLACED IN I-CHEM SPECIALTY CLEANED CONTAINERS AND SEALED.

D AUGER CUTTNGS-ROCK

DOTHER Sal/Rack REMARKS: 


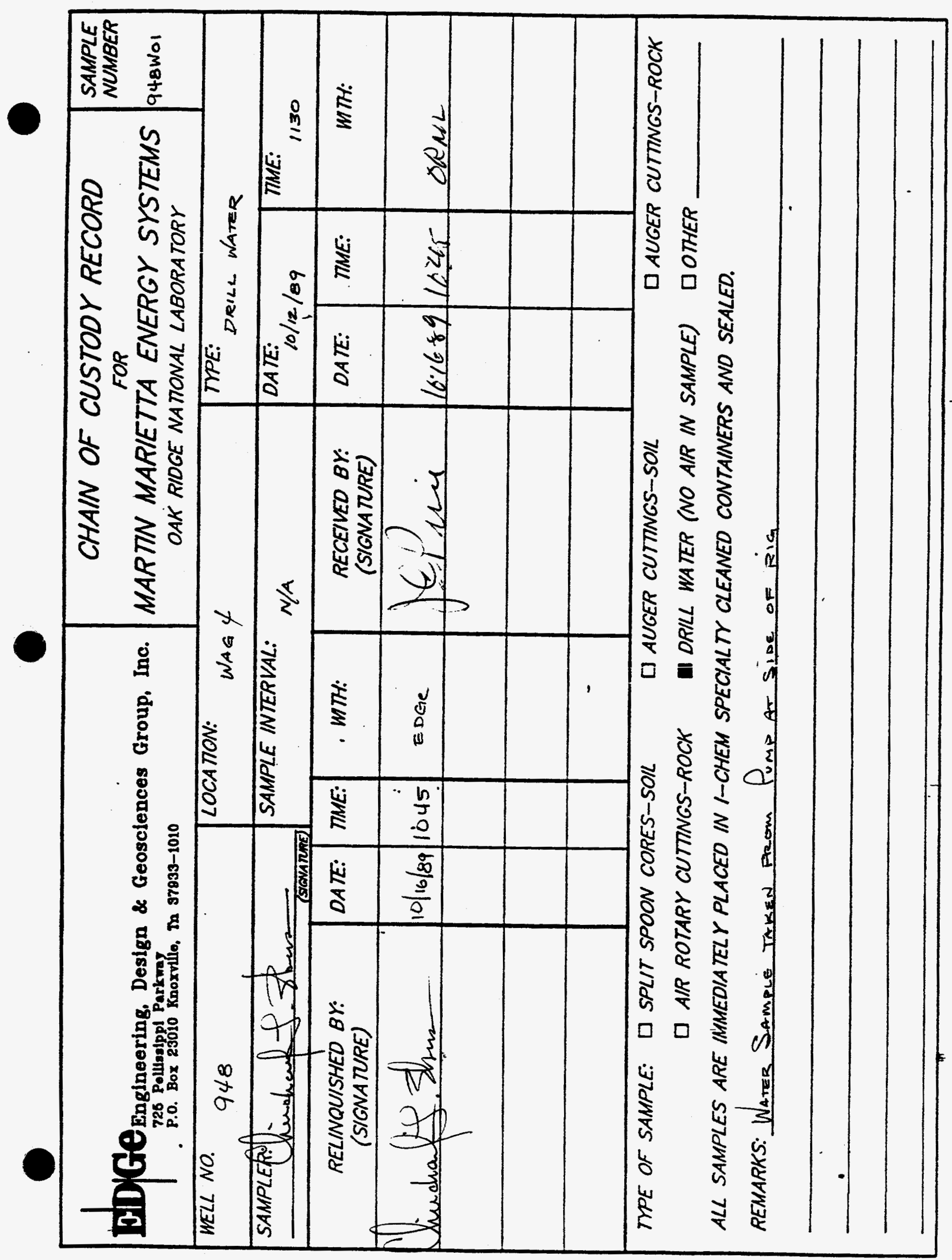


ERC / EDGE

Environmental

and Enercy

Services Co.
NONITANG WZL PROCPAM

WIL DATA GKGRATVE

\subsection{General Information}

\subsection{We11 Location}

Monitoring well number 949 is located in WAG 4. It is located on the west side of WAG 4 approximately 150 feet south of the intersection of Chemical waste Area Road and Lagoon Road. The location is shown on ORNL drawing number C3E20004A075. Survey coordinates for this well are $N$ $18,977.1629, \mathrm{E} 27,004.2363$ (X-10 grid) or latitude $35^{\circ}-54^{\prime}$ 48.55" and longitude $84^{\circ}-19^{\prime}-21.01^{\prime \prime}$. Coordinate data were provided by Martin Marietta Energy systems. The method used for conversion from $x-10$ grid to Tennessee-Lambert state Plane coordinates came from the publication "Tennessee Valley Authority Data Services Branch and Mapping Services Branch, Oak Ridge, Tennessee, DOE Plant Control, November 6, 1985, Field Book: Ess-3115, pp. 120." The latitude and longitude were calculated by Adams Craft Herz Walker Engineering, Inc., using methods from the U.S. Coast and Geodetic Survey Publication 62-4, "state Plane Coordinates by Automatic Data Processing."

\subsection{Drilling Information}

Well number 949 was drilled by Geotek Engineering Company. An Ingersoll Rand $\mathrm{T}-4$ and a Mobile B-50 auger rig were used to drill this boring for monitor well installation under operation of Rick Herron and Larry Ledbetter with the assistance of James Shelton and Fred Dixon. Drilling commenced on september 28, 1989, and was finished on October 13, 1989. Paragraph 2.4.1 includes a detailed discussion of the well installation and a well schematic is included on the well installation/completion form. A 
synopsis of the drilling activity follows. This information was typed directly from field notes and was edited only when necessary for clarification.

9-26-89 The auger rig, augers and tools were decontaminated.

9-28-89 Drilling equipment was loaded and moved to the well site along with the auger rig. The rig was set up and a 14.0 inch boring was augered to 6.5 feet. A 10.0 inch diverter casing was installed.

10-13-89 The air rotary rig and tools were decontaminated, mobilized to the site and set up. The diverter head and containment box were rigged up and an 8.0-inch tricone was used to drill from 6.5 feet to a total depth of 33.5 feet. After 20 minutes, the water level increased by 1.5 feet. Based on the water level in Wel.l 948 (17.0 feet below land surface) the well was set as per M.Mclaughlin. A 15.94 feet section of 2.0-inch screen and 19.50 foot section of 2.0-inch casing was installed and grouted.

10-16-89 The well was tested with the "Go - No Go" gauge. The gauge became lodged at 20.0 feet. The well was retested by using a submersible pump. The pump reached the total depth and was passed by R. C. Williams. 
This well was logged by ERC Environmental and Energy Services Co., Inc., hydrogeologist C. Allison Hodges and Michael L. Ebers. All well construction materials and supplies were from Martin Marietta Energy Systems approved batches. The batch origin of individual items is shown on the included Monitoring Well Materials Certification form.

\subsection{Technical Information}

\subsection{Decontamination Procedures}

The drilling rig, down hole tools, surface casing, stainless steel screen, stainless steel casing, centralizers, and stainless steel silt trap underwent the cleaning decontamination procedures outlined in the drilling specifications (Release specific Technical Directions for Regulatory Compliance Monitoring Wells Phase 1, Oak Ridge National Laboratory, Oak Ridge, W.0. K-4147, April 1987, pgs. 2-4). A checklist of the cleaned materials is included with this data package.

\subsection{Geology}

WAG 4 is located in Melton Valley which is in the Valley and Ridge Physiographic Province of East Tennessee. WAG 4 is underlain by shale, siltstone, and limestone of the Middle to Upper Cambrian Conasauga Group. The Conasauga Group in the Oak Ridge Area consists of six formations. They are, in ascending order, the Pumpkin Valley shale, Rutledge Limestone, Rogersville Shale, Maryville Limestone, Nolichucky shale and the Maynardville Limestone. The Pumpkin Valley Shale and Rutledge Limestone underlie WAG 4. strike in and near WAG 4 ranges from $N 85^{\circ} \mathrm{E}$ to $\mathrm{N} 15^{\circ} \mathrm{E}$ and 
dip varies from $27^{\circ}$ to vertical. These variations in strike and dip indicate that the conasauga has been deformed in the locale of WAG 4 .

\subsection{Sample collection}

A drill water sample was collected from the water pump on the drill rig on october 13, 1989. Analytical results for Sample 949 WOl can be obtained from the Remedial Action Program data base at ORNL.

The Ingersoll Rand T-4 compressed air was not sampled.

\subsection{Installation and Development}

\subsubsection{Installation}

This was a Type D well. A 14.0-inch diameter boring was augered from ground surface to 6.5 feet and a 10.0-inch diameter diverter casing was installed from 0.0 feet to 6.5 feet and grouted. The air rotary method was required to complete the boring to the specified total well depth. An 8-inch diameter boring was drilled with an air rotary tricone roller bit from 6.5 to 33.4 feet. A 2-inch diameter stainless steel silt trap was installed from 33.14 feet to 33.38 feet. A 2-inch diameter stainless steel screen was installed above the silt trap from 33.14 feet to 17.20 feet. Above the screen a 2-inch diameter stainless steel casing was installed from 17.20 feet to 2.3 feet above ground surface. A sandpack was then tremied into the 
annular space from 14.50 to 33.38 feet, with a 2.3 -foot bentonite pellet seal poured into the annular space above the sandpack from 12.20 to 14.50 feet. The annular space from the top of the bentonite seal to the surface was tremie-grouted with a cement/bentonite slurry. A detail of the well is included on the well installation/completion form.

2.4.2 We1l Development

Well number 949 was developed to remove drill cuttings, silt, and other fines. The monitoring well was developed using a Geoguard pump with an air compressor. All pumps were cleaned prior to use according to specified cleaning procedures (see Paragraph 2.1). The well was developed until a measured total of 350 gallons of water had been evacuated and the clarity of the discharge water was approved by the company representative. The final turbidity value measured at completion was 3.0 NTU's. A development form showing the exact method of development and other pertinent data is appended.

\subsubsection{Installation of Dedicated Monitoring Well Pump}

After the well was developed, a Geoguard Model No. 5614 dedicated monitoring well pump was installed on May 30, 1990, at a depth of 31.5 feet below ground surface. These pumps are decontaminated at American sigma and are sent prepackaged. A copy of the pump certification is kept on file at ORNL. 


\subsection{Hydraulic conductivity Testing}

Well number 949 was tested for the determination of hydraulic conductivity of the aquifer in the vicinity of the well screen. This was accomplished by instantaneously adding a known quantity of water to the monitoring well and measuring the recovery of the water level over time. The changing water levels were measured using a Druck 15 psi pressure transducer and an Omnidata Datapod II data recorder. The hydraulic conductivity value of $1.34 \times 10^{-5}$ $\mathrm{cm} / \mathrm{second}$ (shown as permeability on the hydraulic conductivity calculations printout attached) was calculated using the Bouwer and Rice method. A computer printout of the hydraulic conductivity calculations is included in this data package. 


\section{PRE-DRILLING CHECKLIST FOR MONITORING WELLS}

PRE-DRILIING TASKS

1. EXCAVTION PERMIT OBTAINED

2. ALL EQUIPMENT HAS BEEN CLEANED BEFORE DRILLNG.

30. SCREEN AND CASING HAVE BEEN WASHED, STEAMED, RINSED WTH OE-IONIZED OR DISTILLED WATER, RINSED WTH ISOPROPV ALCOHOL, WRAPPED WTH PROTECTVE COVERING AND STORED OFF THE GROUND.

36. PRE-PACKAGED SCREENS, CASING AND CENTRALIZERS MERE USED.

4. WORK AREA FOR SAMPLE EXAMINATION COVERED WIH CLEAN POL YETHRENE.

5. CLEAN KNIVES, GLOVES, SAMPLE JARS AND LABELS ON HAND.

6. POLYETHILENE COVER IN PLACE OVER HOLE.

7. AIR ROTARY COMPRESSED AIR SAMPLED.
COMPUANCE

\begin{tabular}{l}
$\frac{{ }_{9-28-89}}{\text { DATE }}$ \\
$\frac{\text { NITALS }}{\text { N/A }}$ \\
N/A \\
\hline
\end{tabular}

$10-13-8$

We

$10-13-89$

Nue

$9-28-89$

$\mathrm{CAH}$

$9-26-89$

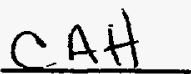

RESULTS:

ADDITIONAL NOTES/OBSERVATIONS:

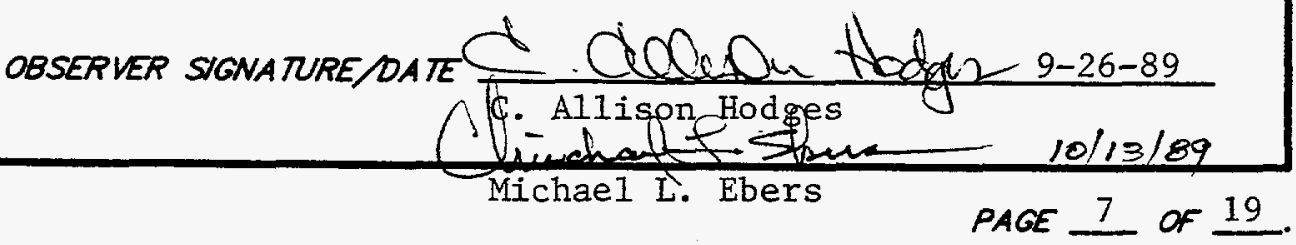




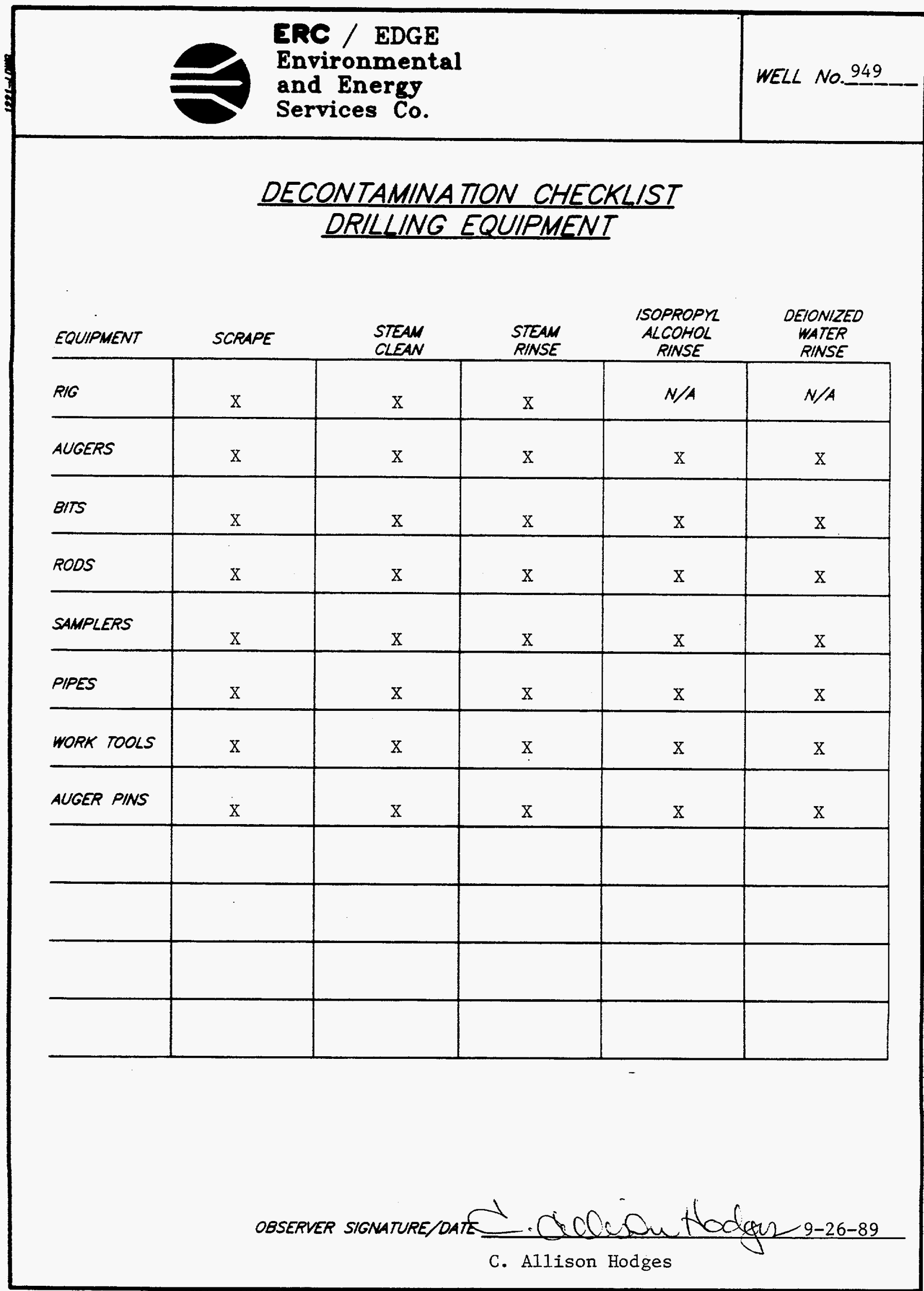




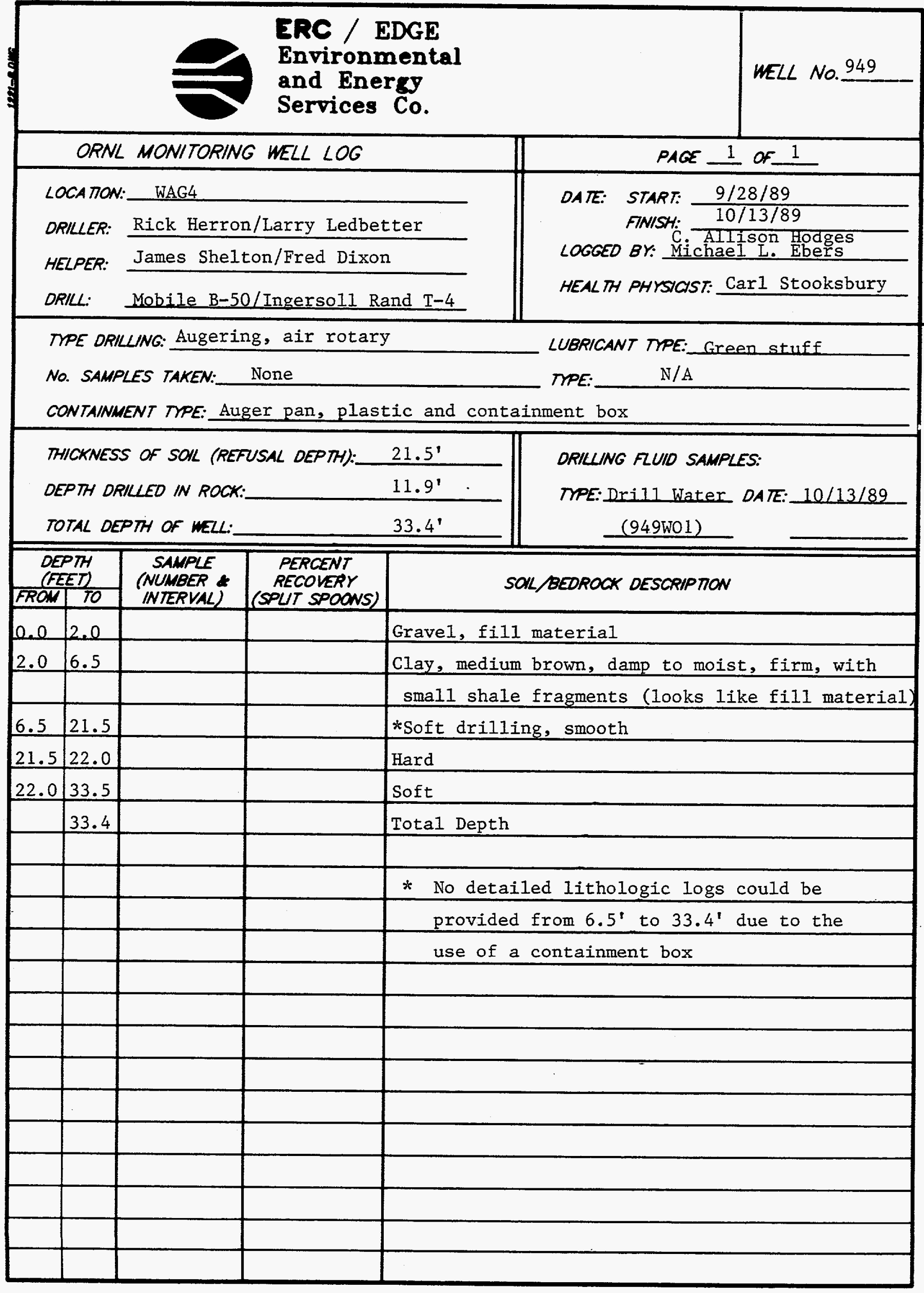




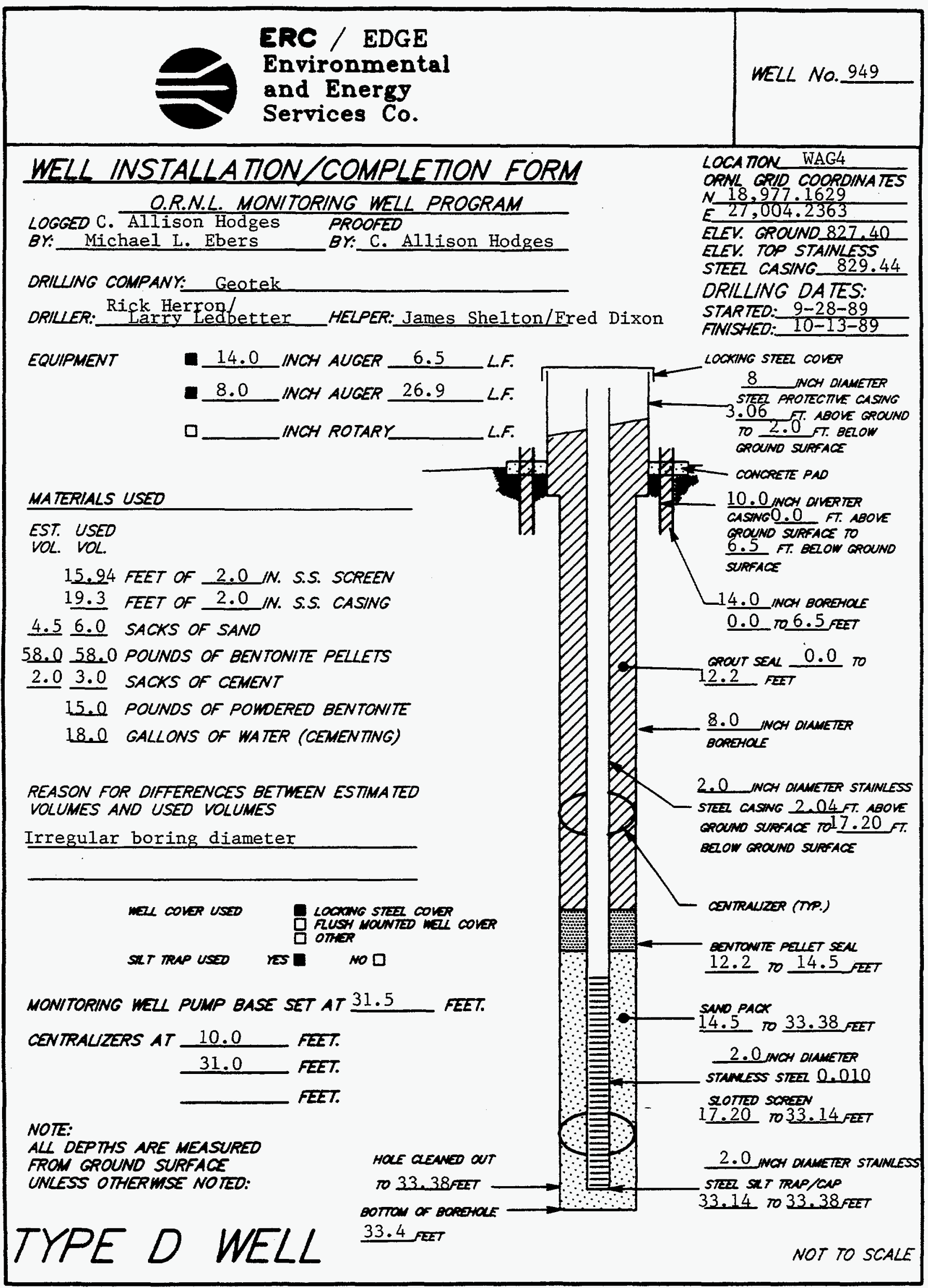


ERC / EDGE

Environmental

WELL NO. 949

and Energy

Services Co.

DATE: $10-13-89$

\section{MONITORING WELL MATERIALS CER TIFICA TION}

ITEM/MA TERIAL

DATE USED BATCH NUMBER

SAND

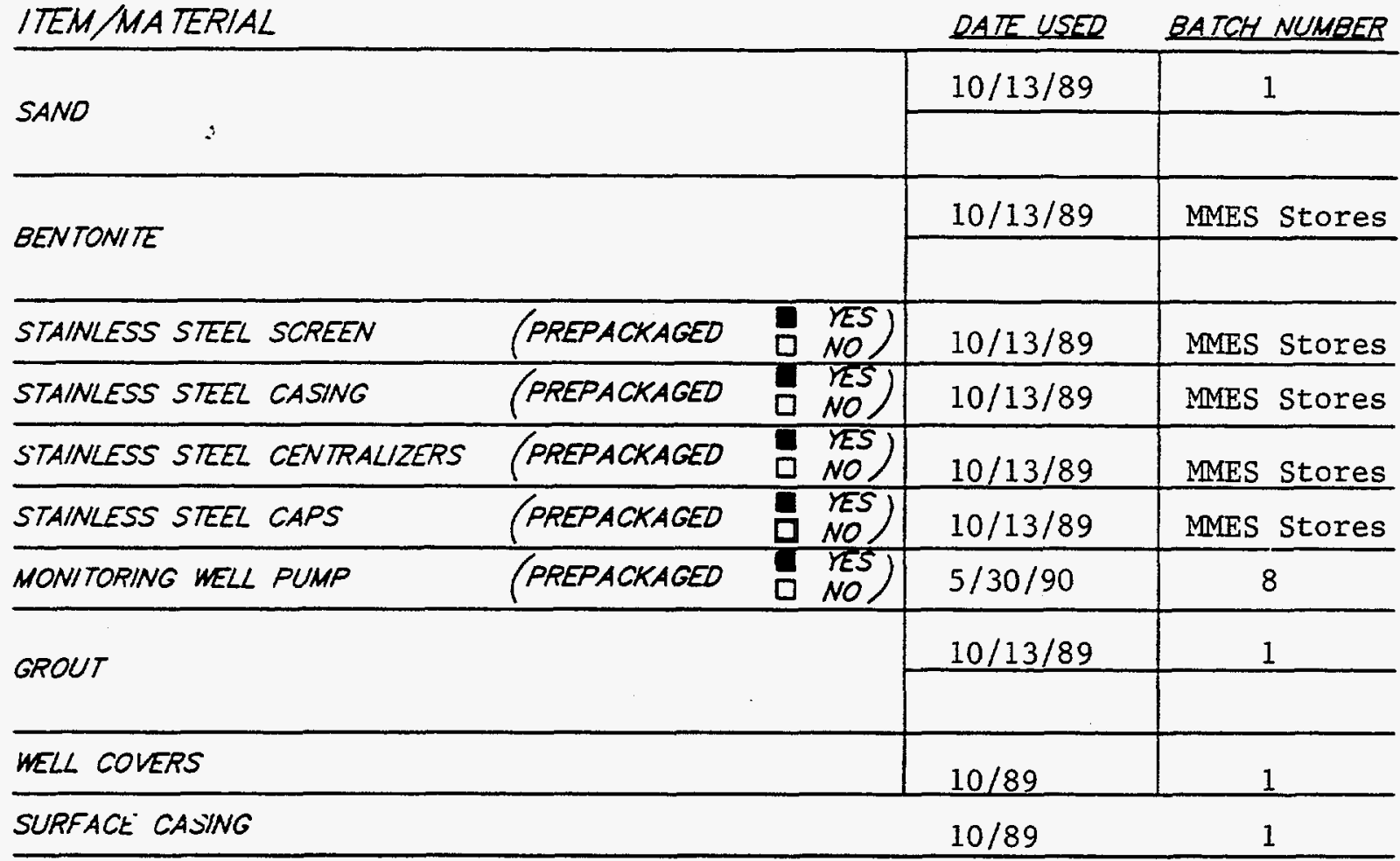

BENTONITE

COMMENTS:

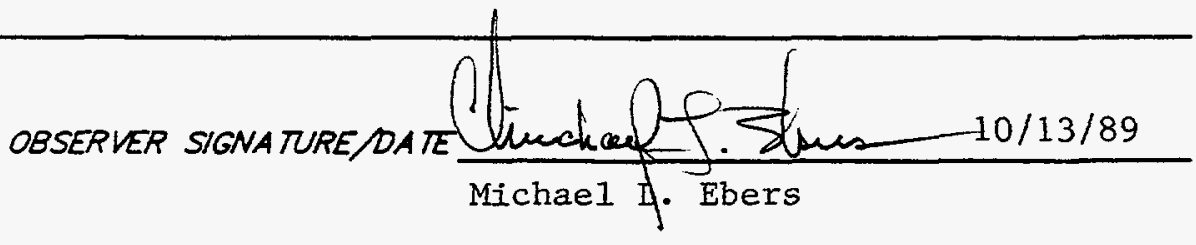

PAGE 11 OF 19 


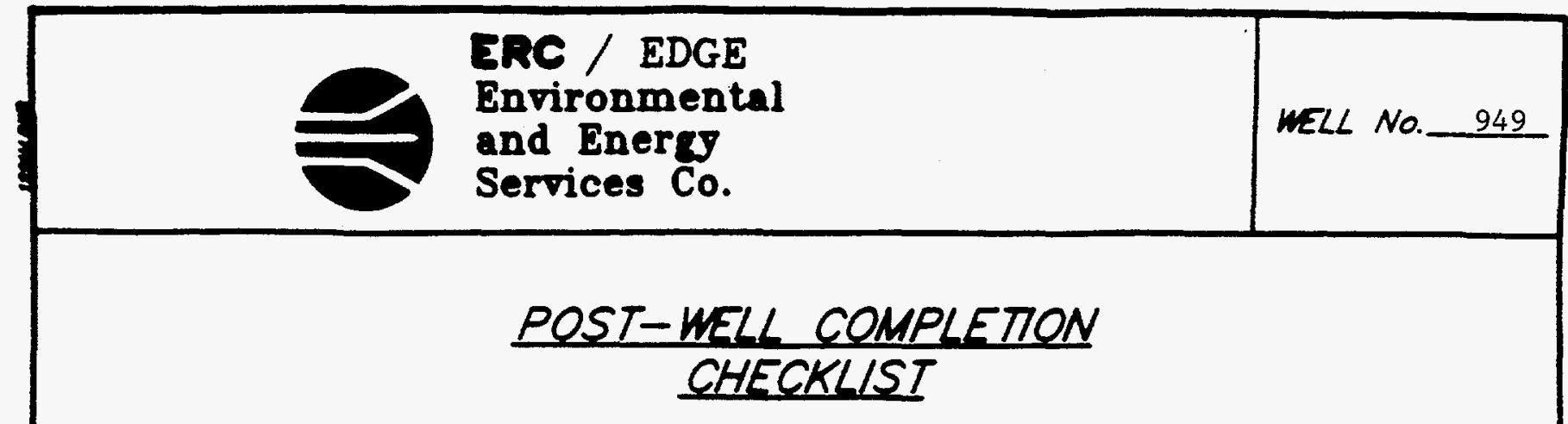

\section{POST-WELL COMPLETION TASKS}

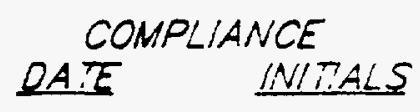

1. WUO SCRAPED FROM AUGERS SAMPLERS ANO ALL OTHER EOUIPWENT.

$10 / 13 / 89$

MUE

2. ALL WUD FRON RTG AND EQUIPNENT SCPAPINGS AND CUTINGS DISPOSED OF IN ACCOROANCE WTH THE SPECAFCA TION PROWOED.

3 WEL DEVEOPED IN ACCOROANCE WTH THE SPECATCA TON PROWOED ANO OETAKS OF THE OEVELOPWENT ACTUTH RECOAOED.

4. ORKLWG STE PROPERLY CLEAMED UP AFTER COMPLETION OF MZL INSTALLATON.

10/13/89 ME

$5 / 30 / 90$

DCL

$10 / 13 / 89$

ME

- RELEASE SPECAFC TECANGL DIRECTONS FOR REQULATORY COMPUANCE WONITORNG MELS PHASE 1. OAK RIDQE NATONAL LABORATOPY, OAK RIDEE W.O. K-4147, APRK 1967.

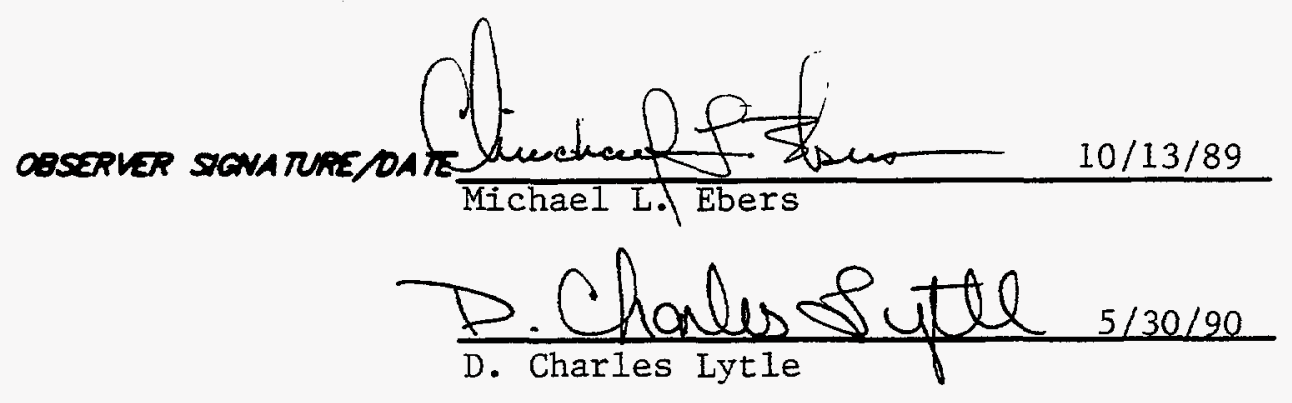




\section{ERCE}

Environmental

and Energy

Services Co.

\section{MONITORING WELL \\ DEVELOPMENT FORM}

DEVELOPMENT DETAILS

METHOD OF

OEVEL OPMENT: Surging and pumping

DEVELOPMENT

BEGAN DATE: $\quad 5 / 24 / 90$ TME:

OEVELOPMENT

ENOING DATE: $\quad 5 / 30 / 90$

DEVELOPMENT

OBSERVED BY: D. Charles Lytle

ONE WELL VOLUME: 11.6 GALLONS

TOTAL GALLONS PUMPED: 350 TOTAL WELL VOLUMES PUMPED: 30.2

INITAL PH: 7.9 FNAL PH: 8.2

INITAL CONOUCTUTY (KS/cm): 687

DESCRIPTION OF INITAL TURBIDITY:

Cloudy

DESCRIPTION OF FNAL TURBIOITY:

Clear

FINAL MEASURED TURBIDITY: 3.0 NTU's

WELL APPROVED BY: R.C. Williams MMES

ODOR

OF WAIER: None

WATER

DISCHARGED

TO:

GROUND SURFACE
STORW SEWERS
DRUNS

口 TANK TRUCK

D STORAQE TANKS

D OTHER

INITAL PRE-DEVELOPMENT

WATER DEPTH: $\quad 7.8$ feet from ground surface

\section{DEVELOPMENT OBSERVATIONS}

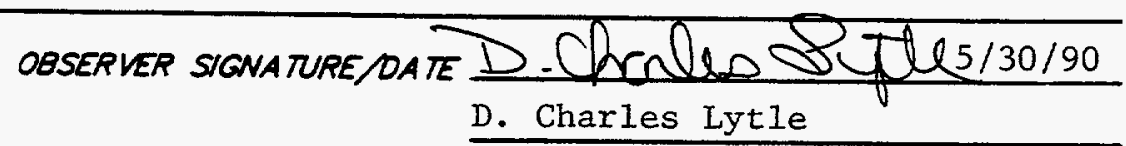




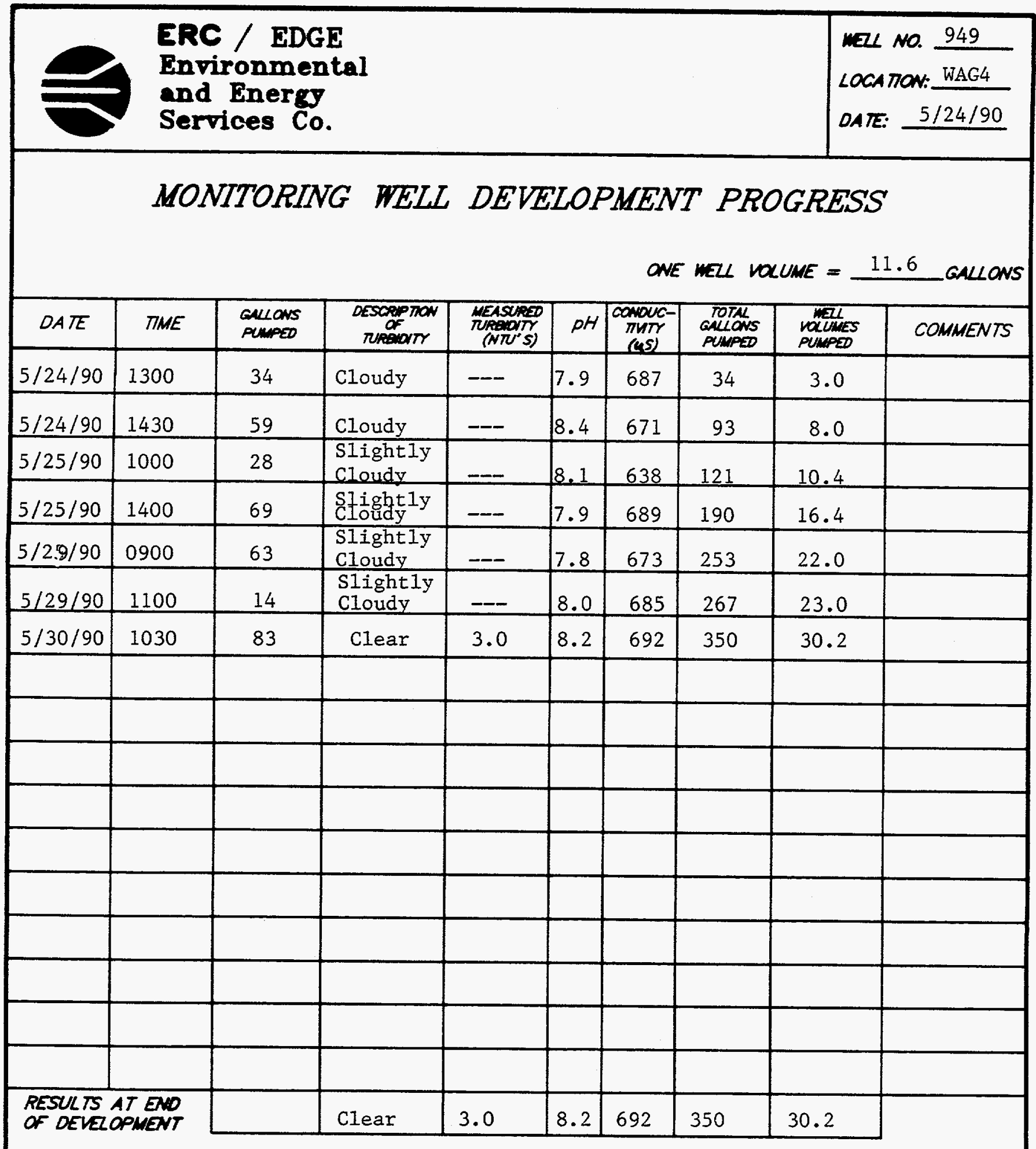

COMMENTS

Good producer. Water remained clean even after surging. Passed with $3.0 \mathrm{NTU}^{\prime} \mathrm{s}$ and 30.2 well volumes. 


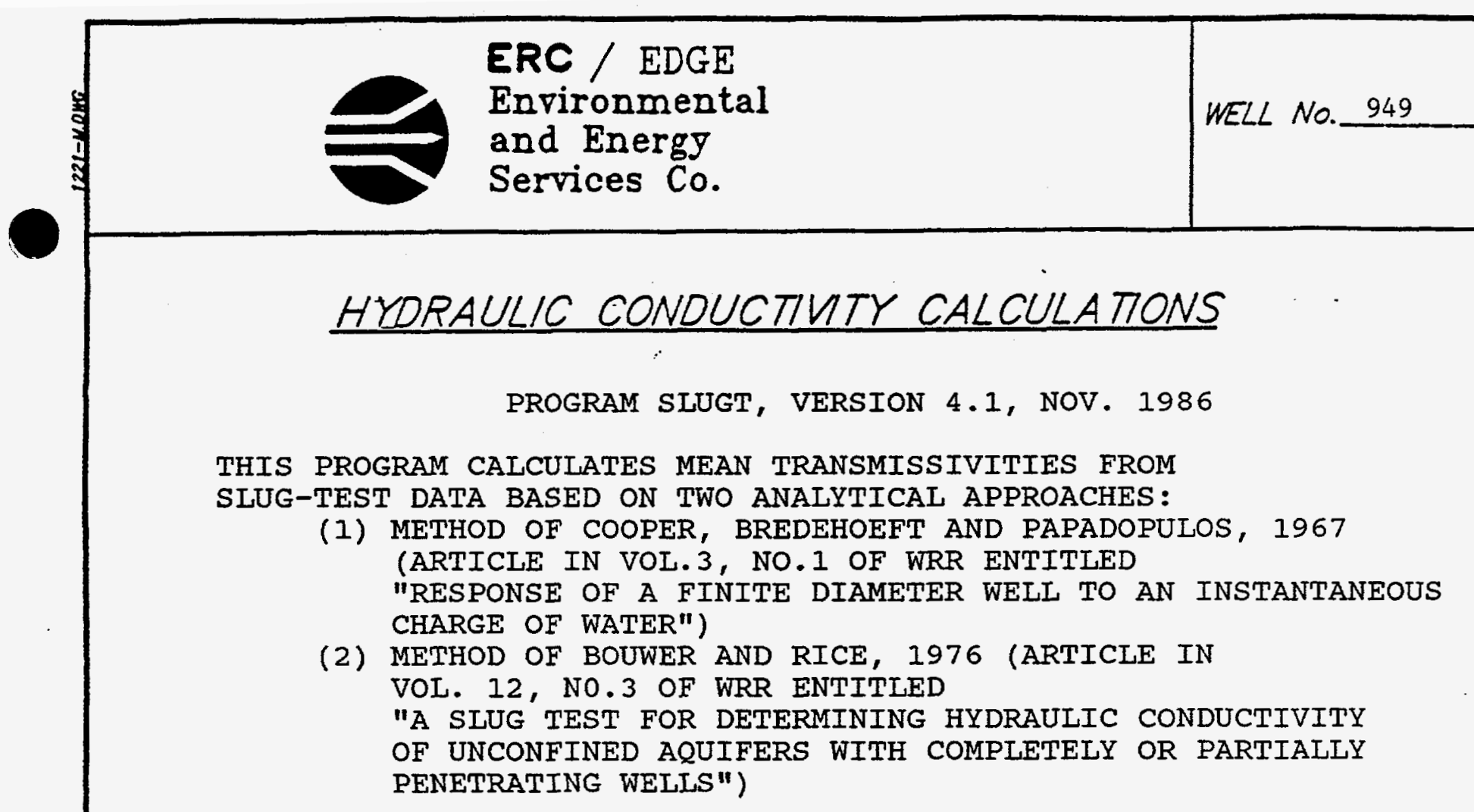

WELI NO.: 949

DATE OF TEST: $11-1-90$

PROJECT NO.: E221-002

CLIENT: MMES

SITE LOCATION: WAG-4

EDGE, INC. FIELD INVESTIGATOR: JAMES W. CARUTHERS

\section{INPUT DATA ARE:}

INNER CASING DIAMETER $=2.00$ INCHES

INNER SCREEN OR OPEN-HOLE DIAMETER $=2.00$ INCHES

DIAMETER OF DRILLED HOLE $=8.00$ INCHES

LENGTH OF SCREEN OR INTAKE PORTION = 15.94 FEET

DEPTH FROM STATIC LEVEL TO BOTTOM OF SCREEN $=20.60$ FEET

THICKNESS OF SATURATED AQUIFER ZONE $=15.94$ FEET

DEPTH TO STATIC WATER LEVEL BELOW REF. POINT $=1.00 \mathrm{FEET}$

ESTIMATED POROSITY OF GRAVEL PACK $=.20$

FALLING-HEAD INDEX $=1$ ("I" IF FALLING, "O" IF RISING)

NUMBER OF DEPTH-TIME DATA POINTS $=32$

HO WAS COMPUTED FROM INTERCEPT OF PLOT OF LOG(H) VS. TIME

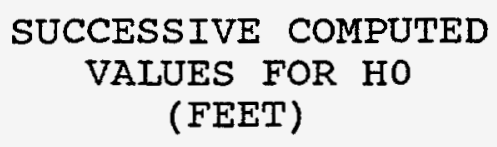

4.2962

4.3153 


\section{HYDRAULIC CONDUCTIVTY CALCULATIONS}

\begin{tabular}{|c|c|c|}
\hline$\left(\right.$ SEC $\left.^{\text {TIME }}\right)$ & $\begin{array}{l}\text { DEPTH TO WATER } \\
\text { (FEET) }\end{array}$ & $\begin{array}{l}\text { HEAD } \\
\text { (FEET) }\end{array}$ \\
\hline $\begin{array}{r}10.00 \\
20.00 \\
30.00 \\
40.00 \\
50.00 \\
60.00 \\
75.00 \\
90.00 \\
105.00 \\
120.00 \\
150.00 \\
180.00 \\
240.00 \\
300.00 \\
360.00 \\
420.00 \\
480.00\end{array}$ & $\begin{array}{l}5.620 \\
5.560 \\
5.470 \\
5.430 \\
5.360 \\
5.310 \\
5.230 \\
5.170 \\
5.110 \\
5.020 \\
4.900 \\
4.790 \\
4.580 \\
4.420 \\
4.290 \\
4.130 \\
4.010\end{array}$ & $\begin{array}{l}4.620 \\
4.560 \\
4.470 \\
4.430 \\
4.360 \\
4.310 \\
4.230 \\
4.170 \\
4.110 \\
4.020 \\
3.900 \\
3.790 \\
3.580 \\
3.420 \\
3.290 \\
3.130 \\
3.010\end{array}$ \\
\hline $\begin{array}{r}540.00 \\
600.00 \\
720.00 \\
840.00 \\
960.00 \\
1080.00 \\
1200.00 \\
1320.00 \\
1440.00 \\
1560.00 \\
1680.00 \\
1800.00 \\
1920.00 \\
2040.00 \\
2160.00\end{array}$ & $\begin{array}{l}3.890 \\
3.750 \\
3.530 \\
3.340 \\
3.190 \\
3.030 \\
2.900 \\
2.760 \\
2.670 \\
2.570 \\
2.470 \\
2.390 \\
2.310 \\
2.260 \\
2.190\end{array}$ & $\begin{array}{l}2.890 \\
2.750 \\
2.530 \\
2.340 \\
2.190 \\
2.030 \\
1.900 \\
1.760 \\
1.670 \\
1.570 \\
1.470 \\
1.390 \\
1.310 \\
1.260 \\
1.190\end{array}$ \\
\hline
\end{tabular}


ERC / EDGE

Environmental

and Energy

WELL NO. 949

\section{HYORAULIC CONDUCTIVTY CALCULATIONS}

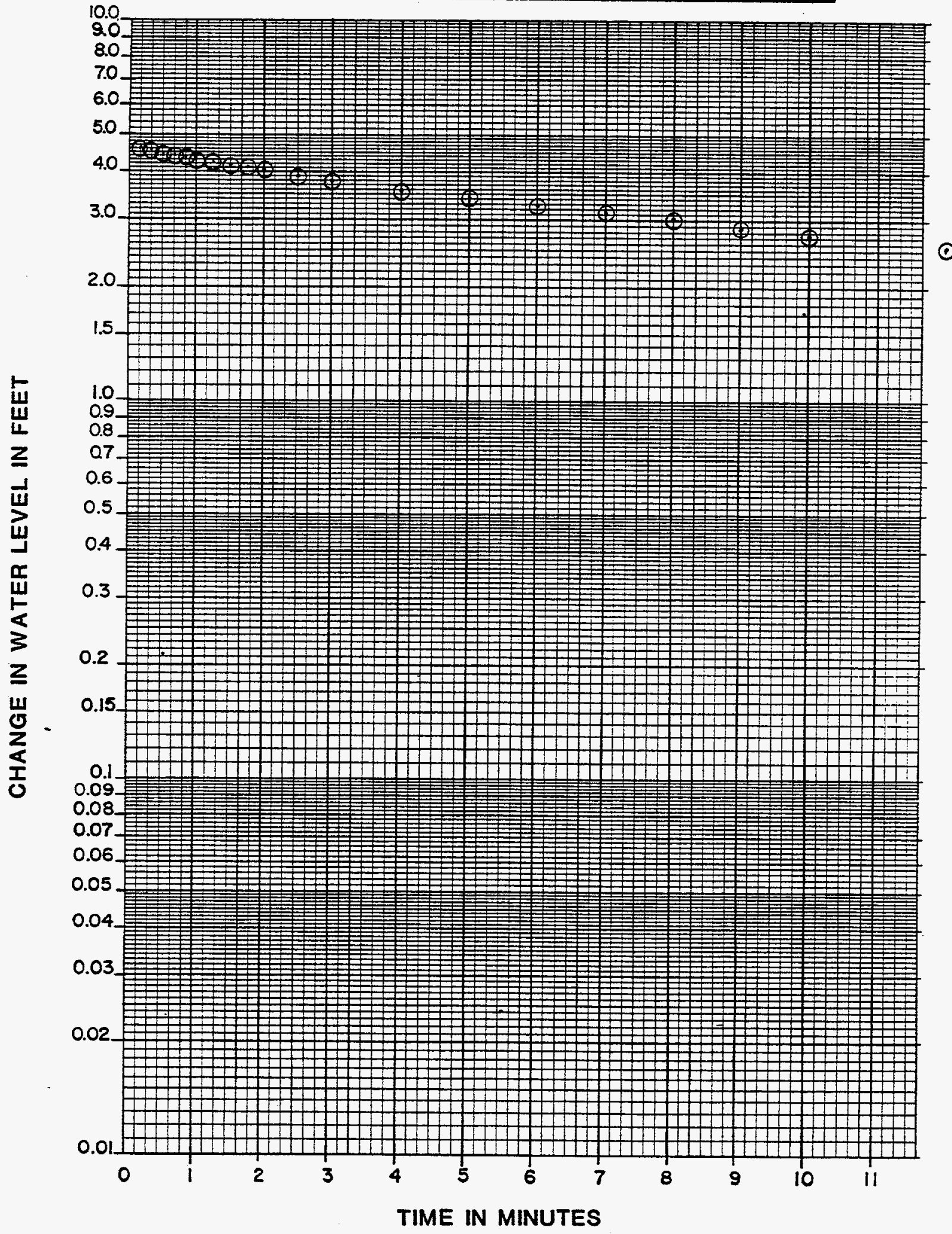

PACE 18 or 19 


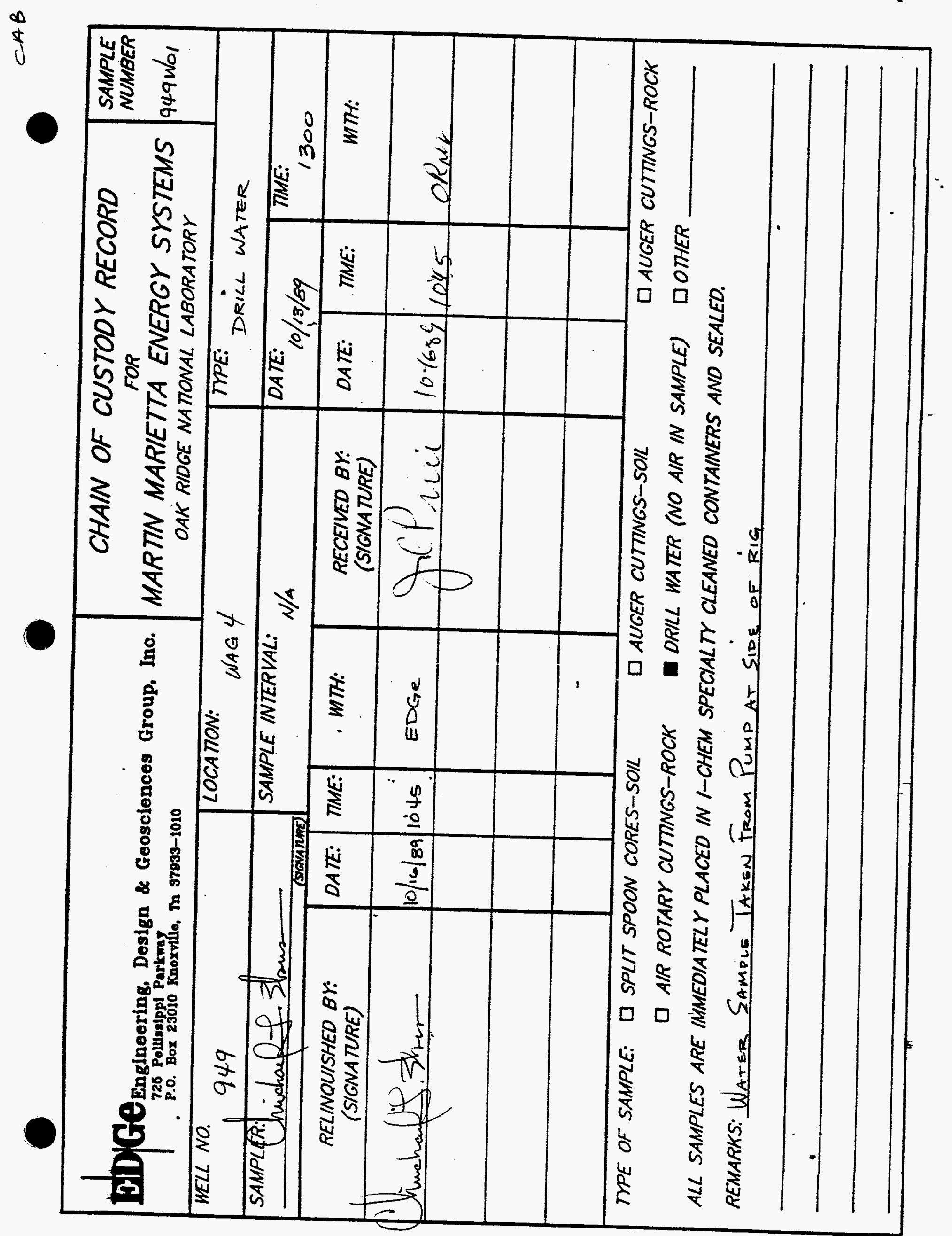


-

- 


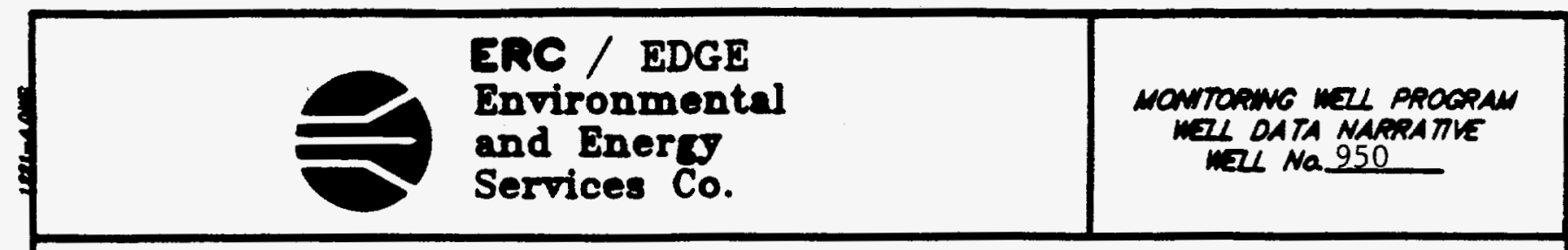

\subsection{General Information}

\subsection{We1l Location}

Monitoring well number 950 is located in WAG 4. It is located north of WAG 4 approximately 130 feet north of Lagoon Road. The location is shown on ORNL drawing number C3E20004A075. Survey coordinates for this well are N $19,594.6062, E 28,013.5128$ (X-10 grid) or latitude $35^{\circ}-$ $54^{\prime}-59.18^{\prime \prime}$ and longitude $84^{\circ}-19^{\prime}-14.99^{\prime \prime}$. Coordinate data were provided by Martin Marietta Energy Systems. The method used for conversion from $\mathrm{x}-10$ grid to TennesseeLambert state Plane Coordinates came from the publication "Tennessee valley Authority Data Services Branch and Mapping Services Branch, Oak Ridge, Tennessee, DOE Plant Control, November 6, 1985, Field Book: ESS-3115, pp. 120." The latitude and longitude were calculated by Adams Craft Herz Walker Engineering, Inc., using methods from the U.S. Coast and Geodetic Survey Publication 62-4, "State Plane Coordinates by Automatic Data Processing."

\subsection{Drilling Information}

Well number 950 was drilled by A.L. Clark Drilling services. A Schramm Rotadrill rig was used to drill this boring for monitor well installation under the operation of Rick Pickel with the assistance of Leo Johnson. Drilling commenced on september 22, 1987, and-was finished on september 23, 1987. Paragraph 2.4.1 includes a detailed discussion of the well installation and a well schematic is included on the well installation/completion form. A 
synopsis of the drilling activity follows. This information was typed directly from field notes and was edited only when necessary for clarification.

9-22-87 The drill rig and tools were steam cleaned. The rig was mobilized to the staked location and set up. Split spoon samples were taken from 0.0 to 1.4 feet. The boring was augered from the surface to 49.5 feet, and bailed.

9-23-90 Bailed hole and set well with 2-inch stainless steel screen, casing, sand pack and bentonite.

This well was logged by ERC Environmental and Energy Services Co., Inc., hydrogeologist Michael L. Ebers. All well construction materials and supplies were from Martin Marietta Energy Systems approved batches. The batch origin of individual items is shown on the included Monitoring Well Materials Certification form.

\subsection{Technical Information}

\subsection{Decontamination Procedures}

The drilling rig, down hole tools, surface casing, stainless steel screen, stainless-steel casing, centralizers, and stainless steel silt trap underwent the cleaning decontamination procedures outlined in the drilling specifications (Release specific Technical Directions for Regulatory Compliance Monitoring Wells Phase 1, Oak Ridge National Laboratory, Oak Ridge, W.O. K-4147, 
ERC / EDGE

Environmental

and Energs

Services Co.
MONTTORNG MEL PROCRAN

WZL DATA NARRATVE

mZl $\mathrm{Na} 950$

April 1987, pgs. 2-4). A checklist of the cleaned materials is included with this data package.

\subsection{Geology}

WAG 4 is located in Melton Valley which is in the Valley and Ridge Physiographic Province of East Tennessee. WAG 4 is underlain by shale, siltstone, and limestone of the Middle to Upper Cambrian Conasauga Group. The Conasauga Group in the Oak Ridge area consists of six formations. They are, in ascending order, the pumpkin Valley shale, Rutledge Limestone, Rogersville Shale, Maryville Limestone, Nolichucky shale and the Maynardville Limestone. The Pumpkin Valley Shale and Rutledge Limestone underlie WAG 4. Strike in and near WAG 4 ranges from $\mathrm{N} 85^{\circ} \mathrm{E}$ to $\mathrm{N} 15^{\circ} \mathrm{E}$ and dip varies from $27^{\circ}$ to vertical. These variations in strike and dip indicate that the conasauga has been deformed in the locale of WAG 4 .

\section{3 sample collection}

Two soil samples were collected during drilling, placed in I-CHEM specialty cleaned glass containers, sealed and submitted to Sample Receiving, Analytical Chemistry Division, Bldg. 4500S, ORNL. Chain of custody forms for these samples are included with this data package. Soil sample 0950501 was collected in the split spoon interval from 1.0 to 1.2 feet on september 22,1987 and soil sample 0950501 was collected in the augered interval at 45 feet on September 22, 1987. 
ERC / EDGE

Environmental

2.4 Installation and Development

\subsubsection{Installation}

This was a Type A well. A 6-inch diameter boring was split spooned and augered from ground surface to a total depth of 49.5 feet. A 2-inch diameter stainless steel screen with welded bottom cap was installed from 28.7 feet to 49.0 feet. A 2-inch diameter stainless steel casing was installed above the screen from 28.7 feet to 2.28 feet above ground surface. A sandpack was then poured into the annular space from 24.0 to 49.0 feet, with a 2.0-foot bentonite pellet seal poured into the annular space above the sandpack from 22.0 to 24.0 feet. The annular space from the top of the bentonite seal to the surface was tremie grouted with a cement/bentonite slurry. A detailed schematic of the well is included on the well installation/completion form.

\subsubsection{We11 Development}

Well number 950 was developed to remove drill cuttings, silt, and other fines. The monitoring well was developed using a Geoguard pump with an air compressor. All pumps and/or bailers were cleaned prior to use according to specified cleaning procedures (see Paragraph 2.1). The well was developed until a measured total of 405 gallons of water had been evacuated and the clarity of the discharge water was approved by the company representative. The final turbidity value measured at completion was 2.0 NTU's. A development form showing the exact method of development and other pertinent data is appended. 
ERC / EDGE

Environmental

and Eneres

Services Co.
MONTROAwG MZL PROCRAM

MIL OATA NAFRATVE

NIL Na. 950

\subsubsection{Installation of Dedicated Konitoring Well Pump}

After the well was developed, a Geoguard Model No. 5614 dedicated monitoring well pump was installed on 5/23/90 at a depth of 47.1 feet below ground surface. These pumps are decontaminated at American Sigma and are sent prepackaged. A copy of the pump certification is kept on file at ORNL.

\subsection{Hydraulic conductivity Testing}

Well number 950 was tested for the determination of hydraulic conductivity of the aquifer in the vicinity of the well screen. This was accomplished by instantaneously adding a known quantity of water to the monitoring well and measuring the recovery of the water level over time. The changing water levels were measured using a Druck 15 psi pressure transducer and an Omnidata Datapod II data recorder. The hydraulic conductivity value of $2.32 \times 10^{-5}$ $\mathrm{cm} / \mathrm{second}$ (shown as permeability on the hydraulic conductivity calculations printout attached) was calculated using the Bouwer. and Rice method. A computer printout. of the hydraulic conductivity calculations is included in this data package. 


\section{PRE-DRILLING CHECKLIST FOR MONITORING WELLS}

PRE-DRILUNG TASKS

1. EXCAVTION PERMIT OBTAINED

2. ALL EQUIPMENT HAS BEEN CLEANED BEFORE DRILING.

30. SCREEN AND CASING HAVE BEEN WASHED, STEAMED, RINSED WTH OE-IONIZED OR DISTILLED WATER, RINSED WTH ISOPROPY ALCOHOL, WRAPPED WTH PROTECTIV COVERING AND STORED OFF THE GROUND.

36. PRE-PACKAGED SCREENS, CASING AND CENTRALIZERS WERE USED.

4. WORK AREA FOR SAMPLE EXAMINATION COVERED WTH CLEAN POLYETHRENE.

5. CLEAN KNIVES, GLOVES, SAMPLE JARS AND LABELS ON HANO.

6. POL YETHRENE COVER IN PLACE OVER HOLE.

7. AIR ROTARY COMPRESSED AIR SAMPLED.
COMPLIANCE

\begin{tabular}{|c|c|}
\hline DATE & INITALS \\
\hline $9 / 22 / 87$ & MUE \\
\hline $9 / 22 / 87$ & $\mu E$ \\
\hline $\mathrm{N} / \mathrm{A}$ & N/A \\
\hline
\end{tabular}

$9 / 23 / 87$

$\mu E$

$9 / 22 / 87$

ME

RESULTS:

ADOITINAL NOTES/OBSERVATIONS:

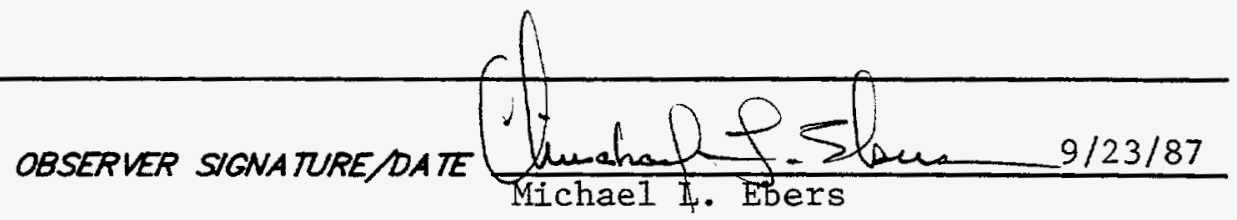


ERC / EDGE

Environmental

and Energy

WELL NO. 250

$\frac{\text { DECONTAMINATION CHECKLIST }}{\text { DRILLING EQUIPMENT }}$

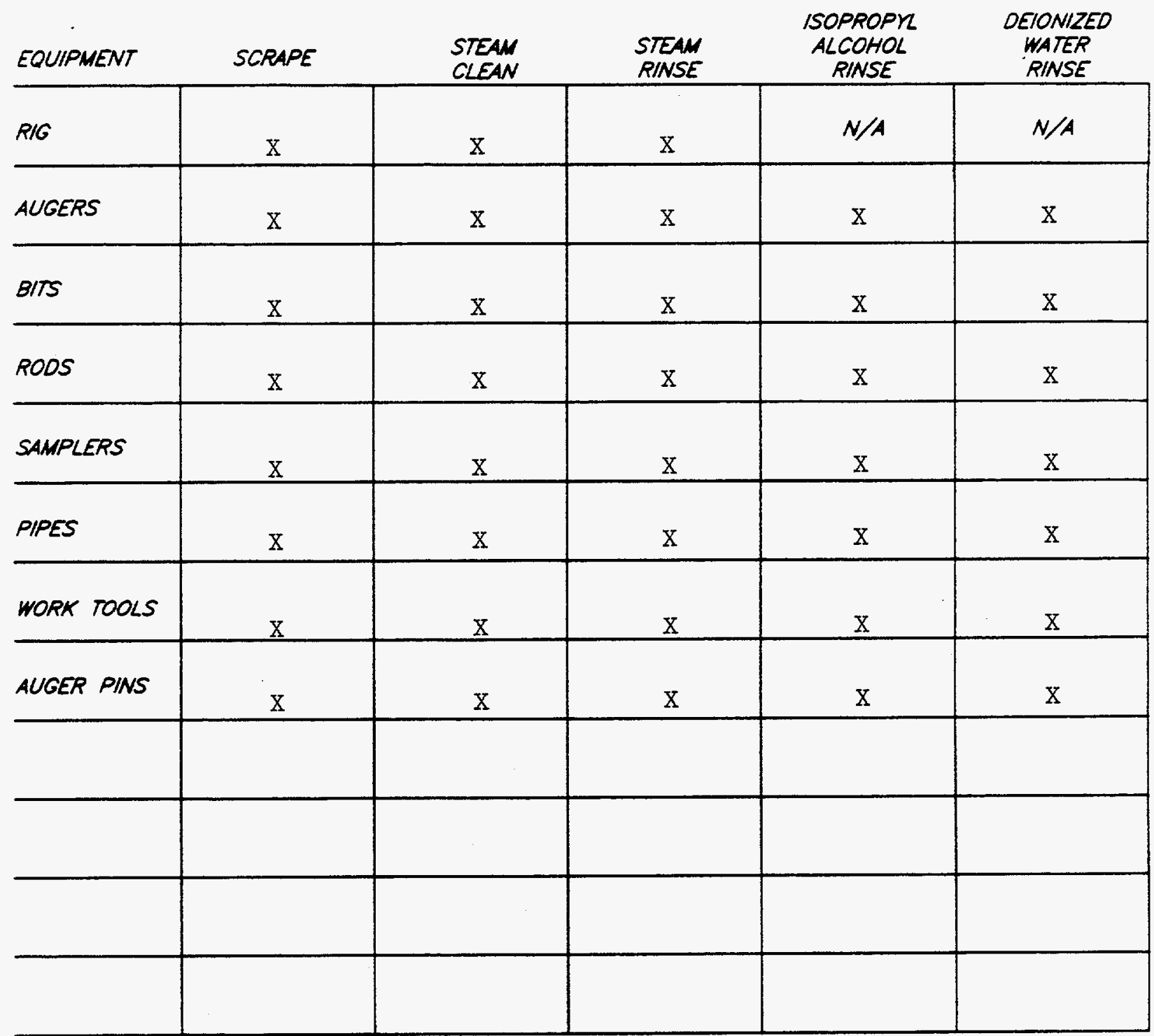

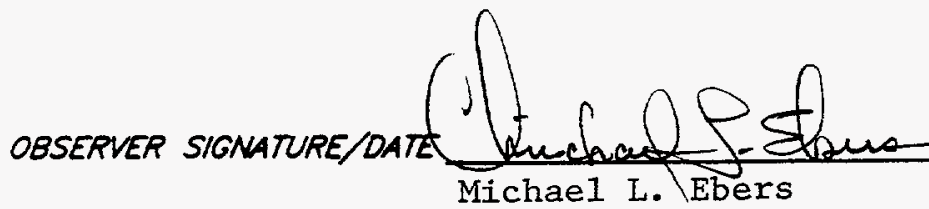

$9 / 22 / 87$

Michae1 L. Ebers

PAGE 7 OF 19 


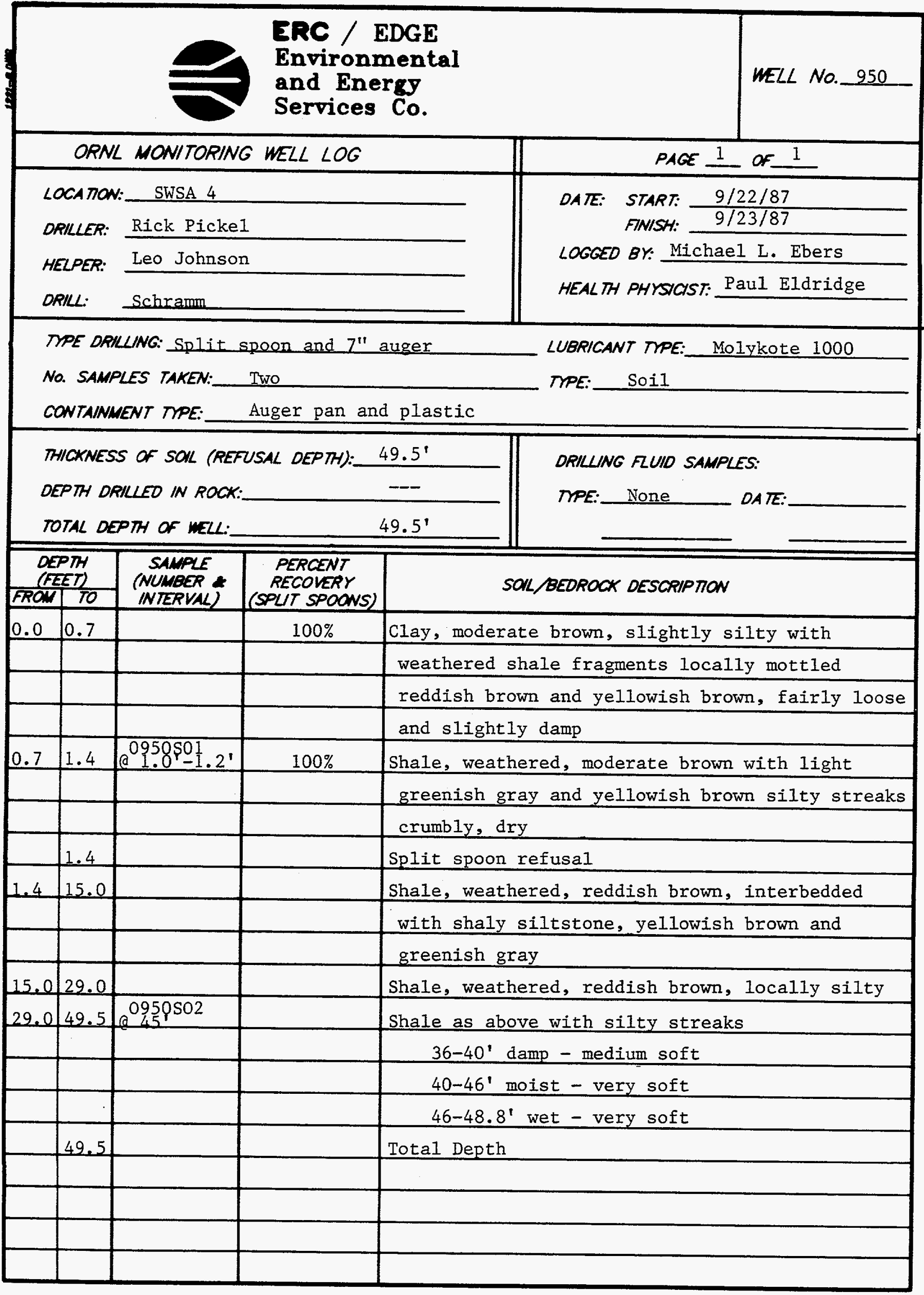




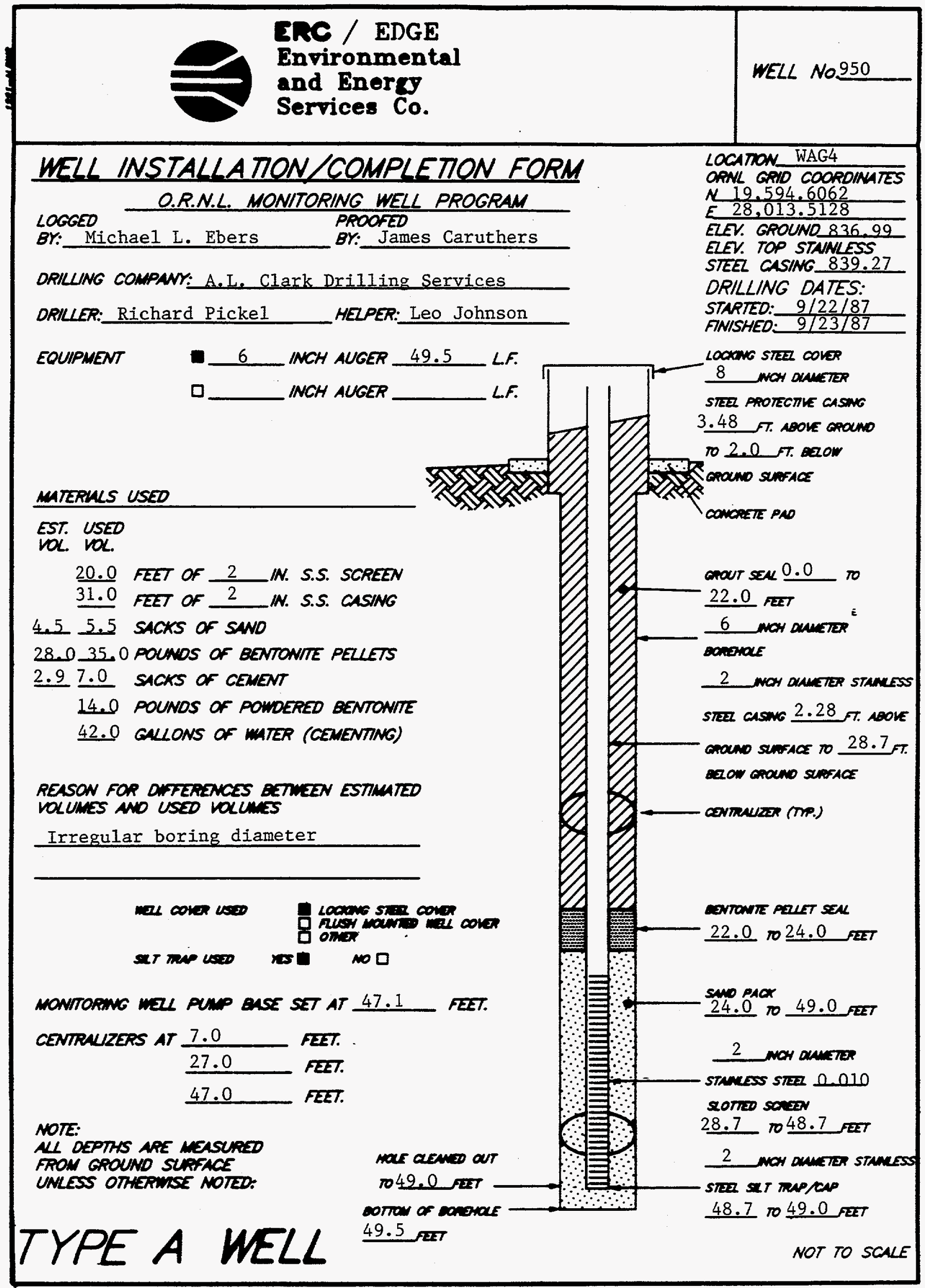

PAEE 9 of 19. 


\section{ERC / EDGE}

Environmental

WELL NO. 950

and Energy

Services Co.

OATE: $2 / 22 / 87$

\section{MONITORING WELL MATERIALS CERTIFICATION}

\begin{tabular}{|c|c|c|}
\hline ITEM/MATERIAL & DATE USED & BATCH NUMBER \\
\hline SANO & $9 / 23 / 87$ & 2 \\
\hline \multirow[t]{2}{*}{ BENTONITE } & $9 / 23 / 87$ & 2 \\
\hline & $9 / 24 / 87$ & 3 \\
\hline (PREPACKAGED $\left.\begin{array}{cc}\text { YES } \\
\text { NO }\end{array}\right)$ & $9 / 23 / 87$ & 5 \\
\hline $\begin{array}{lll}\text { STAINLESS STEEL CASING (PREPACKAGED } & \text { YES } \\
\text { NO }\end{array}$ & $9 / 23 / 87$ & 5 \\
\hline STAINLESS STEEL CENTRALIZERS (PREPACKAGED $0 \begin{array}{c}\text { VES } \\
\text { NO }\end{array}$ & $9 / 23 / 87$ & 5 \\
\hline $\left.\begin{array}{lll}\text { STAINLESS STEEL CAPS } & \text { (PREPACKAGED } & \text { VES } \\
\text { NO }\end{array}\right)$ & $9 / 23 / 87$ & 5 \\
\hline $\begin{array}{ll}\text { MONITORING WELL PUMP } \quad \text { (PREPACKAGED } & \left.0 \begin{array}{c}\text { YES } \\
\text { NO }\end{array}\right) \\
\end{array}$ & $5 / 23 / 90$ & 6 \\
\hline GROUT & $2 / 24 / 87$ & 11 \\
\hline \multicolumn{3}{|l|}{ WELL COVERS } \\
\hline SURFACE CASING & $9 / 87$ & 2 \\
\hline
\end{tabular}

COMMENTS:

OBSERIER SIGNATURE DA TE 
ERC / EDGE

Environmental

and Enerey

WELL NO.950

Services Co.

\section{POST-MELL COMPLETION \\ CHECKLIST}

\section{POST-WELL COMPLETION TASKS}

\section{COMPLIANCE \\ DATE INITIALS}

1. WUO SCRAPED FROW AUGERS SAMPLERS AND ALL

$9 / 23 / 87$ MLE OTHER EOUIPUENT.

$9 / 23 / 87$ AKE

2. ALL WUO FROM RIG ANO EQUIPIENT SCRAPWGS ANO CUTTNOS OISPOSED OF IN ACCOROANCE WIT THE SPECHCA IION * PROWOED.

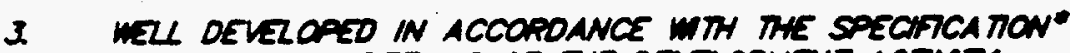
PROVOED ANO OETAKS OF THE OEVZLONENT ACTUTH RECOROED.

4. DRULNG STE PROPERLY CLEANED UP AFTER COMPLETION OF MEL NSTALLATON.

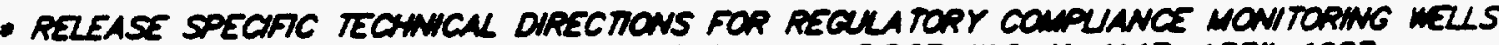
PHASE l, OAK RHDEE NATIONAL LAOORATORY, OAK RIOEE MO. K-4147, APRK 1987.

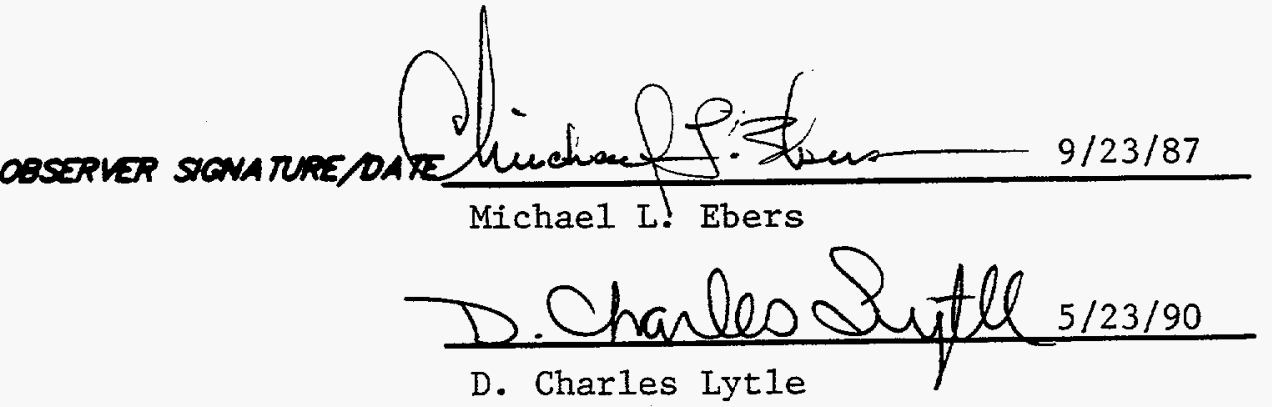




\section{MONITORING WELL \\ DEVELOPMENT FORM}

DEVELOPMENT DETAILS

METHOO OF

QEVELQPMENT: Surging and pumping

OEVELOPMENT

BEGAN DATE: $\quad 5 / 17 / 90$ TME:

OEVELOPMENT

ENOING DATE: $\quad 5 / 23 / 90$

DEVELOPMENT

OBSERVED BY:

D. Charles Lytle

ONE WELL VOLUME: 16.8 GALLONS

TOTAL GALLONS PUMPED: 405

TOTAL WELL VOLUMES PUMPED:24.1

INITAL PH: 7.3

FNAL PH: 7.4

INITAL CONDUCTUTY ( $\mathrm{KS} / \mathrm{cm}$ ): 390

FINAL CONOUCTUTY ( $\mu \mathrm{s} / \mathrm{cm}): 211$

DESCRIPTON OF INITAL TURBIOITY: ClOUdY

DESCRIPTION OF FINAL TUREIOIT: Clear

FINAL MEASURED TURBIDITY:

2.0

WELL APPROVED BY: R.C. Williams MMES

OOOR

OF MATER: NONE

WATER

DISCHARGED

TO:

GROUNO SURFACE

[ STORM SEWERS

D DRUNS
口 TANK RRUCK

[] STORACE TANKS

$\square$ OTHER

WITAL PRE-DEVEOPMENT

WATER DEPTH: $\quad 1.2$ feet from ground surface

DEVELOPMENT OBSERVATIONS 


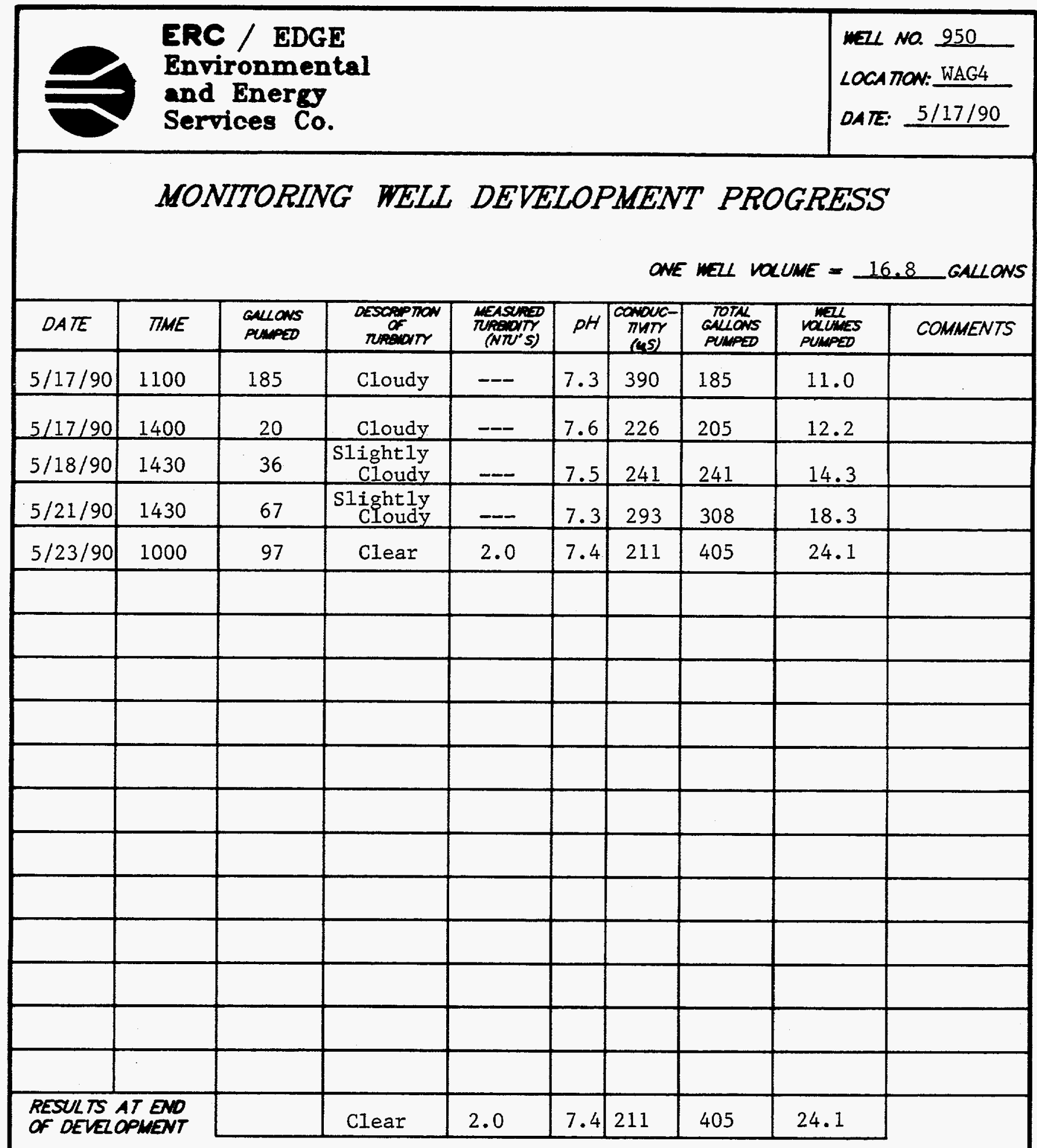

COMMENTS Good producer. Water remained clean after surging. Passed with 2.0 NTU's and moved to another hole. 


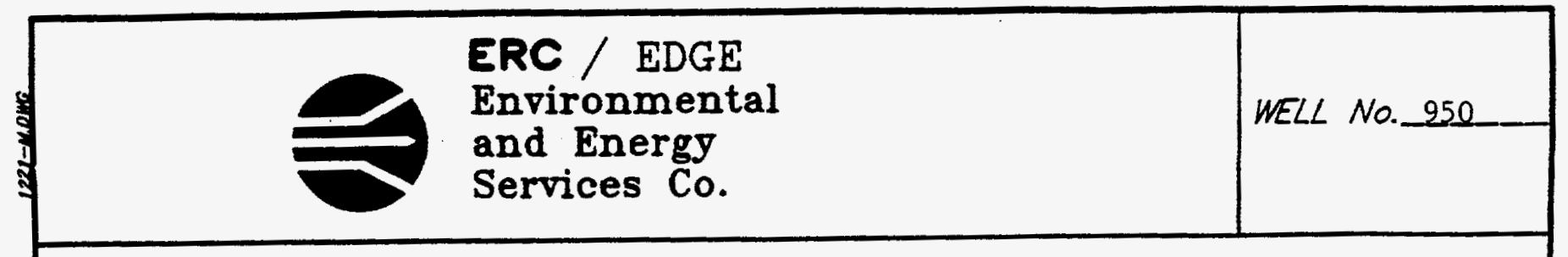

\section{HYDRAULIC CONDUCTIVTY CALCULATIONS}

PROGRAM SLUGT, VERSION 4.1, NOV. 1986

THIS PROGRAM CALCULATES MEAN TRANSMISSIVITIES FROM

SLUG-TEST DATA BASED ON TWO ANALYTICAL APPROACHES:

(1) METHOD OF COOPER, BREDEHOEFT AND PAPADOPULOS, 1967 (ARTICLE IN VOL.3, NO.1 OF WRR ENTITLED

"RESPONSE OF A FINITE DIAMETER WELL TO AN INSTANTANEOUS CHARGE OF WATER")

(2) METHOD OF BOUWER AND RICE, 1976 (ARTICLE IN

VOL. 12 , NO.3 OF WRR ENTITLED

"A SLUG TEST FOR DETERMINING HYDRAULIC CONDUCTIVITY OF UNCONFINED AQUIFERS WITH COMPLETELY OR PARTIALLY PENETRATING WELIS")

WELL NO.: 950

DATE OF TEST: $9-25-90$

PROJECT NO.: E221-002

CLIENT: MMES

SITE LOCATION: WAG-4

EDGE, INC. FIELD INVESTIGATOR: JAMES W. CARUTHERS

INPUT DATA ARE:

INNER CASING DIAMETER $=2.00$ INCHES

INNER SCREEN OR OREN-HOLE DIAMETER $=2.00$ INCHES

DIAMETER OF DRILLED HOLE $=6.00$ INCHES

LENGTH OF SCREEN OR INTAKE PORTION $=20.00 \mathrm{FEET}$

DEPTH FROM STATIC LEVEL TO BOTTOM OF SCREEN $=38.30$ FEET

THICKNESS OF SATURATED AQUIFER ZONE $=20.00 \mathrm{FEET}$

DEPTH TO STATIC WATER LEVEL BELOW REF. POINT $=1.00$ FEET

ESTIMATED POROSITY OF GRAVEL PACK $=.20$

FALLING-HEAD INDEX = 1 ("1" IF FALLING, "0" IF RISING)

NUMBER OF DEPTH-TIME DATA POINTS $=32$

HO WAS COMPUTED FROM INTERCEPT OF PLOT OF LOG(H) VS. TIME

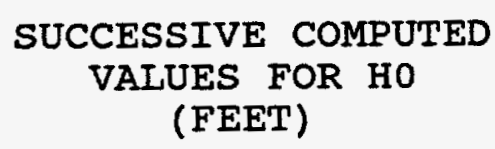

VALUES FOR HO

(FEET)

3.3989

3.4678

PAGE 14 OF 19. 


\section{HYDRAULIC CONDUCTIVTY CALCULATIONS}

\begin{tabular}{|c|c|c|}
\hline (SEC $^{\text {TIME }}$ & $\begin{array}{l}\text { DEPTH TO WATER } \\
\text { (FEET) }\end{array}$ & $\begin{array}{l}\text { HEAD } \\
\text { (FEET) }\end{array}$ \\
\hline $\begin{array}{r}10.00 \\
20.00 \\
30.00 \\
40.00 \\
50.00 \\
60.00 \\
75.00 \\
90.00 \\
105.00 \\
120.00 \\
150.00 \\
180.00 \\
240.00 \\
300.00 \\
360.00 \\
420.00 \\
480.00\end{array}$ & $\begin{array}{l}6.240 \\
6.010 \\
5.750 \\
5.550 \\
5.350 \\
5.160 \\
4.930 \\
4.700 \\
4.480 \\
4.290 \\
3.990 \\
3.740 \\
3.310 \\
3.000 \\
2.760 \\
2.580 \\
2.390\end{array}$ & $\begin{array}{l}5.240 \\
5.010 \\
4.750 \\
4.550 \\
4.350 \\
4.160 \\
3.930 \\
3.700 \\
3.480 \\
3.290 \\
2.990 \\
2.740 \\
2.310 \\
2.000 \\
1.760 \\
1.580 \\
1.390\end{array}$ \\
\hline $\begin{array}{r}540.00 \\
600.00 \\
720.00 \\
840.00 \\
960.00 \\
1080.00 \\
1200.00 \\
1320.00 \\
1440.00 \\
1560.00 \\
1680.00 \\
1800.00 \\
1920.00 \\
2040.00 \\
2160.00\end{array}$ & $\begin{array}{l}2.260 \\
2.130 \\
1.950 \\
1.810 \\
1.710 \\
1.650 \\
1.790 \\
1.730 \\
1.690 \\
1.610 \\
1.630 \\
1.560 \\
1.540 \\
1.500 \\
1.490\end{array}$ & $\begin{array}{r}1.260 \\
1.130 \\
.950 \\
.810 \\
.710 \\
.650 \\
.790 \\
.730 \\
.690 \\
.610 \\
.630 \\
.560 \\
.540 \\
.500 \\
.490\end{array}$ \\
\hline
\end{tabular}




\begin{tabular}{|l|l|}
\hline $\begin{array}{l}\text { ERC / EDGE } \\
\text { Environmental } \\
\text { and Energy } \\
\text { Services Co. }\end{array}$ & WELL No. 950 \\
\hline HYDRAULIC CONDUCTIVTY CALCULATIONS \\
\hline
\end{tabular}

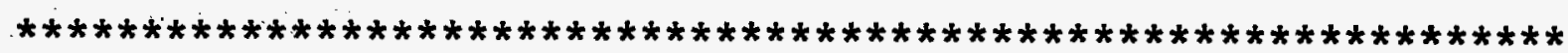

METHOD OF BOUWER AND RICE

COMPUTED RESULTS USING DIAMETER OF DRILLED HOLE:

PERMEABILITY $=7.62 \mathrm{E}-07 \mathrm{FT} / \mathrm{SEC} \quad=2.32 \mathrm{E}-05 \mathrm{cM} / \mathrm{SEC}$

TRANSMISSIVITY $=1.52 \mathrm{E}-05 \mathrm{FT} * 2 / \mathrm{SEC}$

COMPUTED RESULTS USING DIAMETER OF CASING AND SCREEN:

PERMEABILITY $=9.52 \mathrm{E}-07 \mathrm{FT} / \mathrm{SEC} \quad=2.90 \mathrm{E}-05 \mathrm{cM} / \mathrm{SEC}$

TRANSMISSIVITY $=1.90 \mathrm{E}-05 \mathrm{FT} * 2 / \mathrm{SEC}$ 


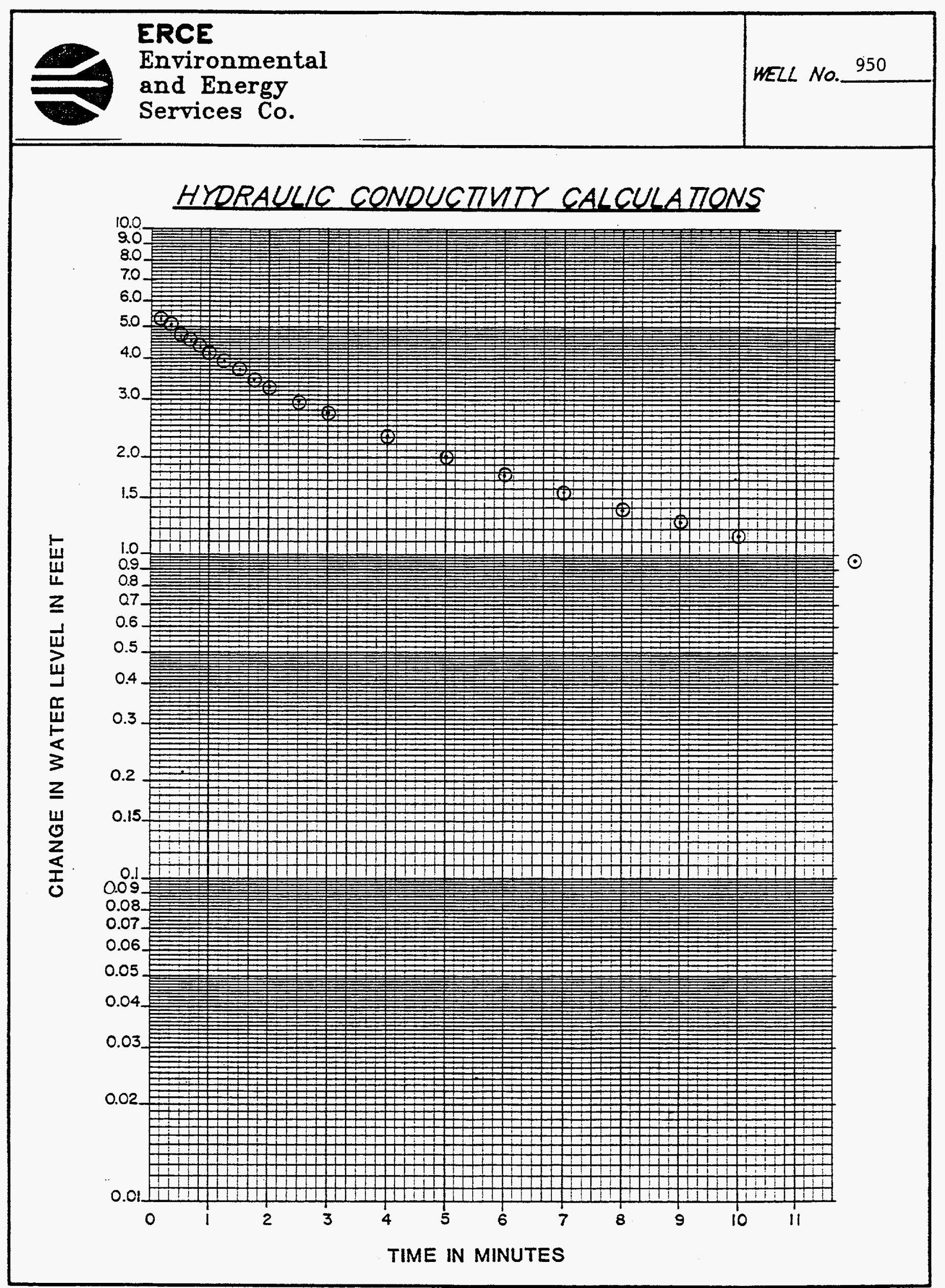

PACE 17 of 19 


\begin{tabular}{|c|c|c|c|c|c|c|c|c|}
\hline $\begin{array}{l}\text { MCI/CON } \\
\text { NASHVILLE } \\
(615) 966-\end{array}$ & $\begin{array}{l}\text { TING EN } \\
\text { IVILLE HUNT } \\
3\end{array}$ & $\begin{array}{l}\text { VGINEEF } \\
\text { SVILLE LOUI }\end{array}$ & LLE & \multicolumn{4}{|c|}{$\begin{array}{c}\text { CHAIN OF CUSTODY RECORD } \\
\text { FOR } \\
\text { MARTIN MARIETTA ENERGY SYSTEMS } \\
\text { OAK RIDGE NATIONAL LABORATORY }\end{array}$} & \multirow[t]{2}{*}{$\begin{array}{l}\text { SAMPLE } \\
\text { NUMBER: } \\
\text { OSSO SOI }\end{array}$} \\
\hline 0950 & & \multirow{2}{*}{\multicolumn{4}{|c|}{$\begin{aligned} \text { LOCATION: } & \text { SWSA } 4 \\
& (a) \text { TO TO } 1.2^{\prime}\end{aligned}$}} & \multicolumn{2}{|r|}{ Sork } & \\
\hline SAMFLE & $\frac{1 \text { InIGNATU }}{1}$ & & & & & \multicolumn{2}{|c|}{ DATE: $9 / 22 / 87$} & \multirow{2}{*}{$\begin{array}{c}\text { TIME: } 10.45 \mathrm{AM} \\
\text { WITH: }\end{array}$} \\
\hline $\begin{array}{l}\text { RELINQUISHED BY: } \\
\text { (SIGNATURE) }\end{array}$ & DATE: & TIME : & wn & TH: & $\begin{array}{l}\text { RECIEVED BY: } \\
\text { (SIGNATURE) }\end{array}$ & DATE : & TIME: & \\
\hline mant I. Strus & $10 / 20 / 87$ & $9: 45 \mathrm{AM}$ & $M C$ & & Naucy llum & $10 / 20 / 87$ & $9: 45$ & ORNL \\
\hline & & & & & O & & & \\
\hline & & & & & & & & \\
\hline & & & & & & & & \\
\hline
\end{tabular}



1.0 General Information

\subsection{Wel1 Location}

Monitoring well number 951 is located in WAG 4 . It is located north of WAG 4 approximately 130 feet north of Lagoon Road. The location is shown on ORNL drawing number C3E20004A075. Survey coordinates for this well are $N$ $19,594.2885, \mathrm{E} 28,028.6975$ (X-10 grid) or latitude $35^{\circ}-54^{\circ}$ $59.26^{\prime \prime}$ and longitutde $84^{\circ}-19^{\prime}-14.83^{\prime}$. Coordinate data were provided by Martin Marietta Energy systems. The method used for conversion from $x-10$ grid to Tennessee-Lambert state plane coordinates came from the publication "Tennessee Valley Authority Data Services Branch and Mapping Services Branch, Oak Ridge, Tennessee, DOE Plant Control, November 6, 1985, Field Book: ESS-3115, pp. 120." The latitude and longitude were calculated by Adams Craft Herz Walker Engineering, Inc., using methods from the U.S. Coast and Geodetic survey Publication 62-4, "state Plane Coordinates by Automatic Data Processing."

\subsection{Drilling Information}

Well number 951 was drilled by A.L. Clark Drilling Services. A Gus Pech rig was used to drill this boring for monitor well installation under the operation of A.L. Clark III. Drilling commenced on 11/23/87, and was finished on 12/1/87. Paragraph 2.4.1 includes a detailed discussion of the well installation and a well schematic is included on the well installation/ completion form. A synopsis of the drilling activity follows. This information was typed directly from field notes and was edited only when necessary for clarification. 
11/23/87: The drill rig and tools were steam cleaned and mobilized to the staked location and set up. The boring was augered from surface to 20.6 feet with 14 inch augers. Ten inch surface casing was installed from the surface to 20.6 feet and grouted in place.

11/30/87: The boring was advanced from 20.6 feet to 70.3 feet with an $85 / 8$ inch tricone air rotary and the boring cleaned out. Four inch stainless steel casing, screen, sand and bentonite were set.

12/1/87: The annular space was grouted to the surface.

This well was logged by ERC Environmental and Energy Services Co., Inc., hydrogeologist Bryn D. Howze. All well construction materials and supplies were from Martin Marietta Energy Systems approved batches. The batch origin of individual items is shown on the included Monitoring Well Materials Certification form.

\subsection{Technical Information}

\subsection{Decontamination Procedures}

The drilling rig, down hole tools, surface casing, stainless steel screen, stainless steel casing, centralizers, and stainless steel silt trap underwent the cleaning decontamination procedures outlined in the drilling specifications (Release specific Technical Directions for Regulatory Compliance Monitoring Wells Phase 1, Oak Ridge National Laboratory, Oak Ridge, W.O. K-4147, April 1987, pgs. 2-4). A checklist of the cleaned materials is included with this data package. 


\subsection{7}

WAG 4 is located in Melton valley which is in the valley and Ridge Physiographic Province of East Tennessee. WAG 4 is underlain by shale, siltstone, and limestone of the Middle to Upper Cambrian Conasauga Group. The Conasauga Group in the Oak Ridge area consists of six formations. They are, in ascending order, the Pumpkin Valley Shale, Rutledge Limestone, Rogersville Shale, Maryville Limestone, Nolichucky Shale and the Maynardville Iimestone. The Pumpkin Valley Shale and Rutledge Limestone underlie WAG 4. Strike in and near WAG 4 ranges from N $85^{\circ} \mathrm{E}$ to $\mathrm{N} 15^{\circ} \mathrm{E}$ and dip varies from $27^{\circ}$ to vertical. These variations in strike and dip indicate that the conasauga has been deformed in the locale of WAG 4.

\section{3 sample collection}

No samples were collected during drilling.

\subsection{Installation and Development}

\subsubsection{Installation}

This was a Type B well. A 14-inch diameter boring was augered from surface to 20.6 feet (auger refusal). A 10inch diameter string of decontaminated steel surface casing was installed from 0.0 feet to 20.6 feet, sealed with a 1.6 foot bentonite pellet layer from 19.0 feet to 20.6 feet, and tremie grouted in place. The surface casing minimizes potential cross contamination between the regolith and bedrock water bearing zones. After the surface casing was 
installed, the air rotary method was used to drill an 8inch diameter boring to a total depth of 70.3 feet. A 4inch diameter stainless steel screen with bottom cap was installed from 70.3 feet to 49.1 feet. A 4-inch diameter stainless steel casing was installed from the top of the screen at 49.1 feet and extended 2.17 feet above ground surface. A sandpack was then poured into the annular space from 70.3 up to 47.5 feet, with a 2.2-foot bentonite pellet seal poured into the annular space above the sandpack from 45.3 to 47.5 feet. The annular space from the top of the bentonite seal to the surface was tremie grouted with a cement/bentonite slurry. A detailed schematic of the well is included on the well installation/completion form.

\subsubsection{Well Development}

Well number 951 was developed to remove drill cuttings, silt, and other fines. The monitoring well was developed using a Geoguard pump with an air compressor. All pumps were cleaned prior to use according to specified cleaning procedures (see. Paragraph 2.1). The well was developed until a measured total of 700 gallons of water had been evacuated and the clarity of the discharge water was approved by the company representative. The final turbidity value measured at completion was 4.0 NTU's. A development form showing the exact method of development and other pertinent data is appended.

2.4.3 Installation of Dedicated Monitoring We1l Pump

After the well was developed, a Geoguard Model No. 5614 dedicated monitoring well pump was installed on 5/30/90 at a depth of 60.4 feet below ground surface. These pumps are 
ERT / EDGE

Environmental

and Energy

MONTOANG WII PROGRAM

Services Co.

WII DATA NARRATE

me ll Na 951

decontaminated at American Sigma and are sent prepackaged. A copy of the pump certification is kept on file at ORNL.

2.5 Hydraulic conductivity Testing

Well number 951 was tested for the determination of hydraulic conductivity of the aquifer in the vicinity of the well screen. This was accomplished by instantaneously adding a known quantity of water to the monitoring well and measuring the recovery of the water level over time. The changing water levels were measured using a Druck 15 psi pressure transducer and an omnidata Datapod II data recorder. The hydraulic conductivity value of $7.64 \times 10^{-6}$ $\mathrm{cm} / \mathrm{second}$ (shown as permeability on the hydraulic conductivity calculations printout attached) was calculated using the Bower and Rice method. A computer printout of the hydraulic conductivity calculations is included in this data package.

PACE 5 of 17 


\begin{tabular}{|l|l|}
\hline $\begin{array}{l}\text { ERC / EDGE } \\
\text { Environmental } \\
\text { and Energy } \\
\text { Services Co. }\end{array}$ & WELL No. 951 \\
\hline & $\frac{\text { PRE-DRILLING CHECKLIST FOR }}{\text { MONITORING WELLS }}$ \\
\hline
\end{tabular}

\section{PRE-DRILLING TASKS}

1. EXCAVATION PERMIT OBTAINED.

2. ALL EQUIPMENT HAS BEEN CLEANED BEFORE DRILLING.

3o. SCREEN AND CASHNGS HAVE BEEN WASHED, STEAMED, RINSED WTH DE-IONIZED OR DISTULED WATER, RINSED WTH ISOPROPY ALCOHOL WRAPPED WTH PROTECTVE COVERING AND STORED OFF THE GROUND.

36. PRE-PACKAGED SCREENS CASINGS AND CENTRALIZERS MERE USED.

4. WORK AREA FOR SAMPLE EXAMINATION COVERED WTH CLEAN POL VETHRENE.

5. CLEAN KNIES, GOVES, SAMPLE JARS AND LABELS ON-HAND.

6. POL YETHRENE COVER IN PLACE OVER HOLE.

AOOIIIONAL NOTES/OBSERVATIONS:

\begin{tabular}{|c|c|}
\hline \multicolumn{2}{|c|}{ COMPLIANCE } \\
\hline $11 / 23 / 87$ & $B D H$ \\
\hline $11 / 23 / 87$ & BDH \\
\hline $\mathrm{N} / \mathrm{A}$ & $\mathrm{N} / \mathrm{A}$ \\
\hline
\end{tabular}

$11 / 30 / 87 \quad B D H$

$11 / 23 / 87$ BDH

$11 / 23 / 87 \quad B D H$

$\underline{11 / 23 / 87 \quad B D H}$ 


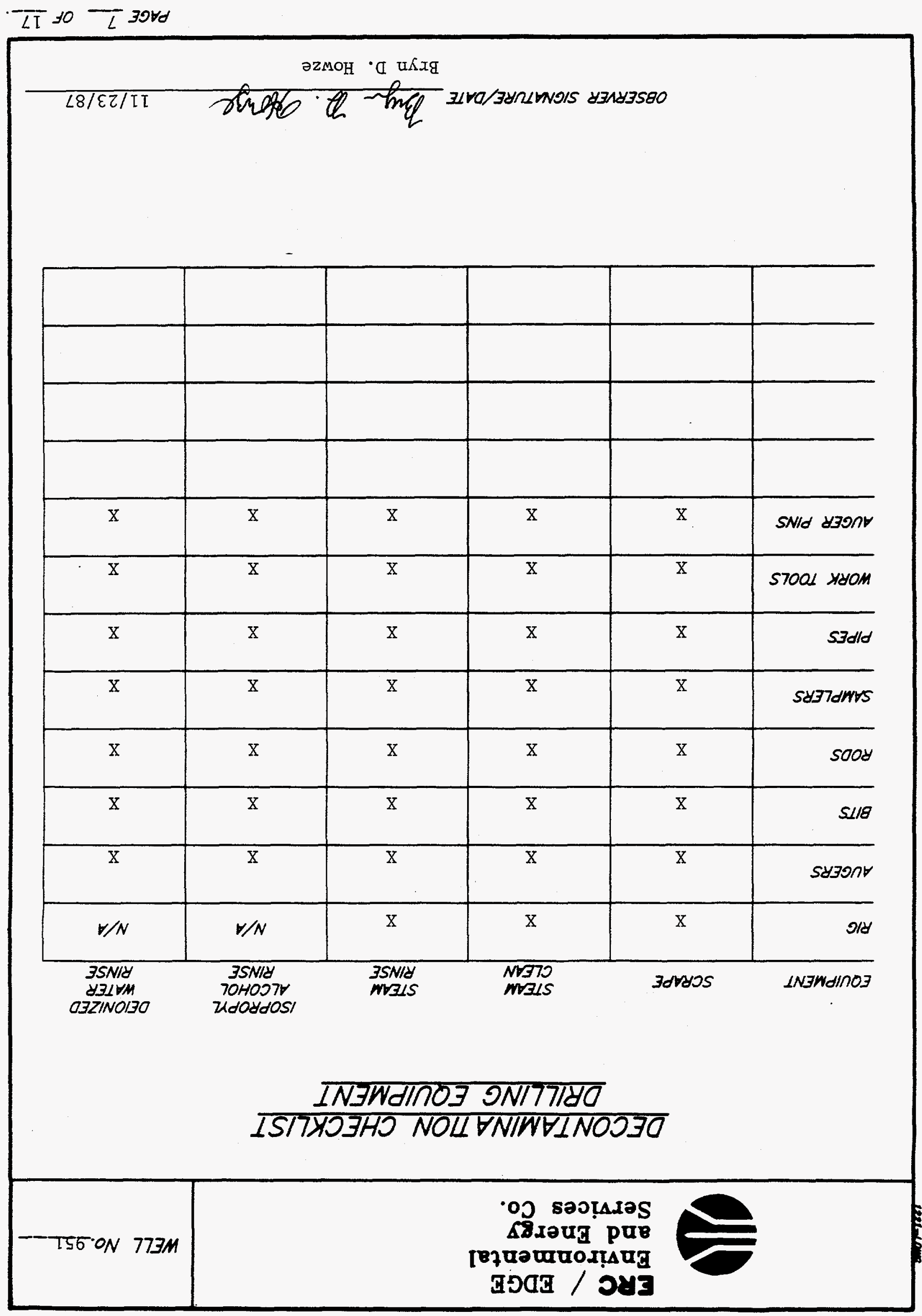


ORNL MONITORING WELL LOG

LOCA HON: SWSA 4

ORILER: Avery L. Clark, III

HELPER: LEo Johnson

DRILL: Gus Pech

TYPE ORILLING: Auger, air rotary

No. SAMPLES TAKEN: None
PAGE 1 OF 1

DATE: START: $11 / 23 / 87$

FINISH: $12 / 11 / 87$

LOGGED BY: Bryn D. Howze

HEALTH PHYSICIST: Paul Eldridge

LUBRICANT TPE: Molykote 1000

TPE: $N / A$

CONTANMENT TYPE: Auger pan, plastic and containment box

THICKNESS OF SOL (REFUSAL DEPTH): 20.6' DEPTH DRILLEO IN ROCK:

$49.7^{\prime}$

TOTAL DEPTH OF MELL:
DRILLING FLUID SAMPLES:

TPE: N/A OATE:

\begin{tabular}{|c|c|c|c|c|}
\hline \multicolumn{2}{|c|}{ 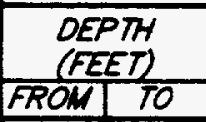 } & $\begin{array}{l}\text { SAMPLE } \\
\text { (NUMBER \& } \\
\text { (NTERVAL) }\end{array}$ & $\begin{array}{c}\text { PERCENT } \\
\text { RECOVERY } \\
\text { (SPUT SPOONS) }\end{array}$ & SOLL BEDROCK DESCRIPTION \\
\hline 0.0 & 0.7 & & & Clay, slightly silty, medium brown, mottled \\
\hline & & & & reddish, yellow, black, with shale fragments \\
\hline & & & & firm \\
\hline 0.7 & 20.6 & & & Shale, weathered, reddish brown, interbedded \\
\hline & & & & with shaly siltstone, yellowish brown and \\
\hline & & & & greenish gray \\
\hline 20.6 & 70.3 & & & No detailed lithologic descriptions are \\
\hline & & & & available for this interval due to use of \\
\hline & & & & containment box \\
\hline & & & & Soft $67^{\prime}-68.5^{\prime}$ \\
\hline & 70.3 & & & Total Depth \\
\hline & & & & \\
\hline & & & & \\
\hline & & & & \\
\hline & & & & \\
\hline & & & & \\
\hline & & & & \\
\hline & & & & \\
\hline & & & & \\
\hline & & & & \\
\hline & & & & \\
\hline
\end{tabular}




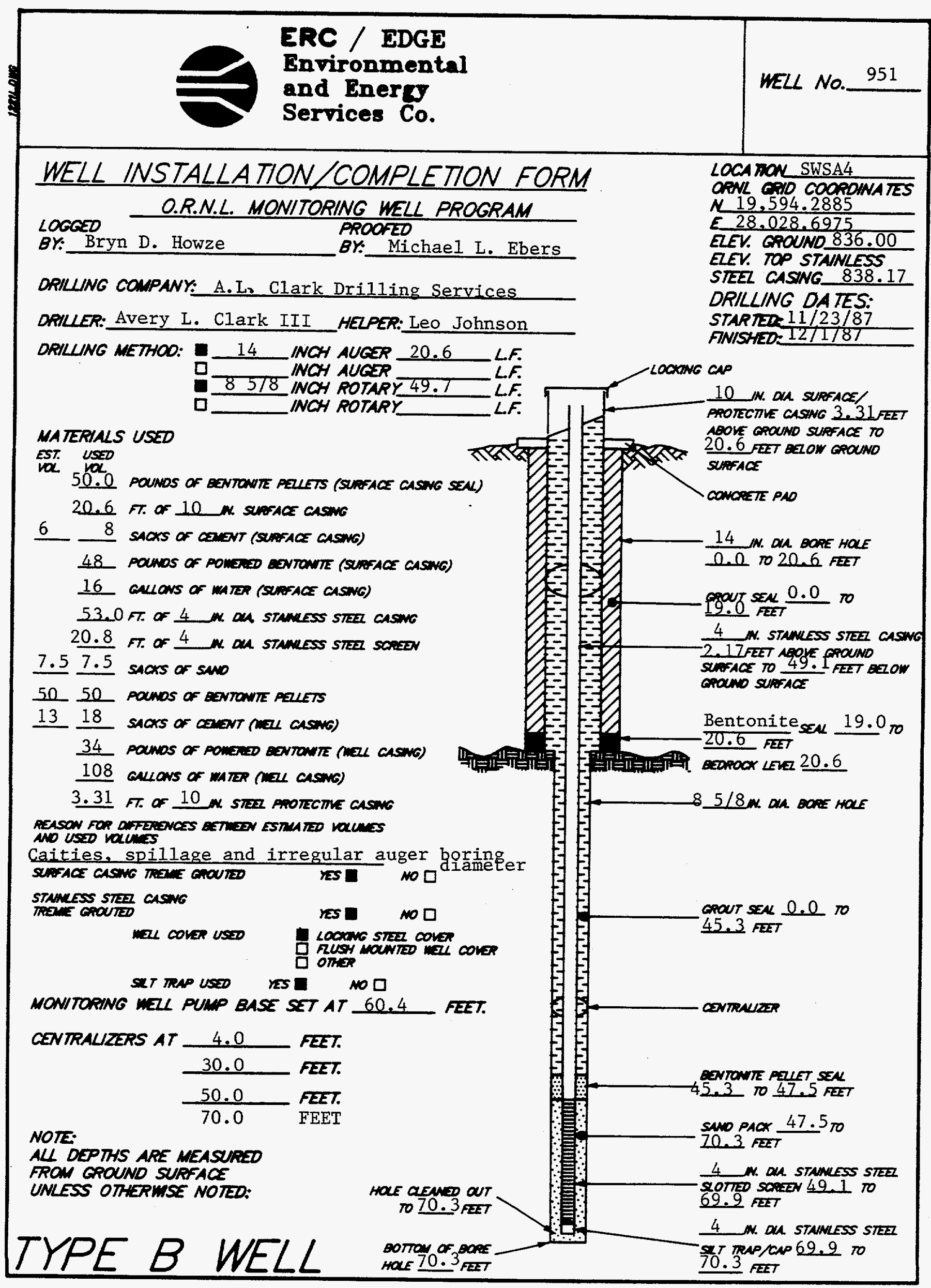

PACE 9 or 17 
ERC / EDGE

Environmental

WELL No.251

and Energy

Services Co.

\section{MONITORING WELL MATERIALS CERTIFICATION}

ITEM/MATERIAL

SAND

BENTONITE

STAINLESS STEEL SCREEN

STAINLESS STEEL CASING

STAINLESS STEEL CENTRALIZERS

STAINLESS STEEL CAPS

MONITORING WELL PUMP

GROUT

WELL COVERS

SURFACE CASING

COMMENTS:

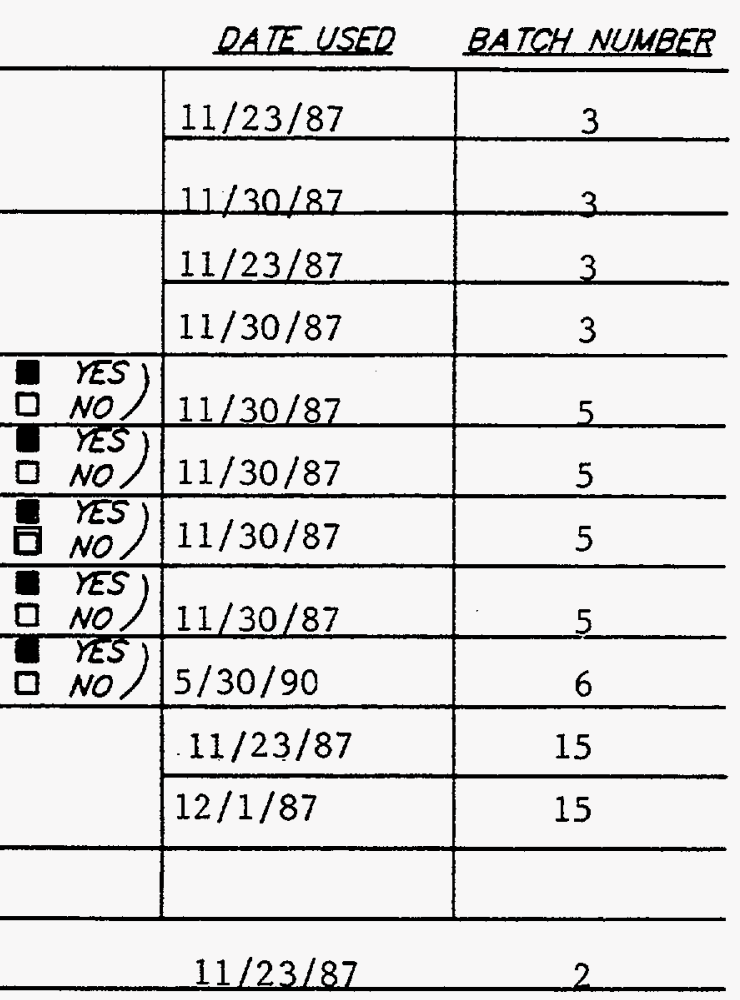

(PREPACKAGED

(PREPACKAGED

(PREPACKAGED

(PREPACKAGED

(PREPACKAGED
D NO

\begin{tabular}{l|l}
\hline VES & $11 / 30 / 87$ \\
\hline
\end{tabular}

$5 / 30 / 90$

$11 / 23 / 87$

$12 / 1 / 87$

$1 / 23 / 87$ 


\section{POST-WELL COMPLETION \\ CHECKLIST}

\section{POST-MELL COMPLETION TASKS}

\section{DATE INITALS}

1. WUD SCRAPED FROM AUGERS SAMPLERS AND ALL

$12 / 1 / 87$

$B D H$ OTHER EQUIPNENT.

2. ALI WUD FROW AIG ANO EOUIPWENT SCRAPINGS ANO CUTTINCS OUSPOSED OF IN ACCORDANCE WTH THE SPECATCA MON " PRO HOED.

3 WEL DEVEZORD IN ACCORDANCE WTH THE SPECARCA HON PROVOED AND OETAKS OF THE DEVEZOPMENT ACTUTH RECOROED.

4. DRKLNG SIT PROPERLY CLEANED UP AFTER COMPLETION OF MZL INSTALLATION.

$12 / 1 / 87 \quad B D H$

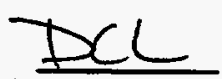

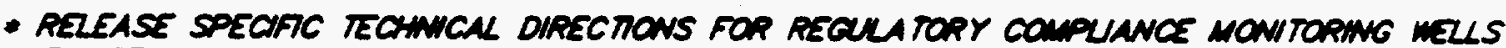
PHASE I, OAK RIDCE NATIONAL LABCRATORY, OAK RIDEE M. K-4147, APRK 1987.

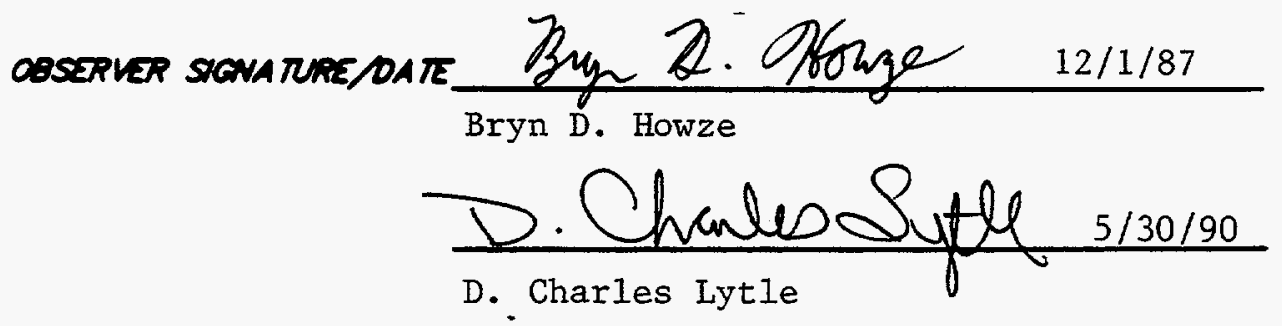




\section{ERCE}

Environmental

and Energy

Services Co.

\section{MONITORING WELL \\ DEVELOPMENT FORM}

DEVELOPMENT DETAILS

METHOO OF

QEVELQPMENT: Surging and pumping

DEVELOPMENT

BEGAN DATE:

$5 / 17 / 90$

TME:

DEVELOPMENT

ENDING DATE: $\quad 5 / 30 / 90$

DEVELOPMENT

OBSERVED BY: D. Charles Lytle

ONE WELL VOLUNE: 62.5 GALLONS

TOTAL GALLONS PUMPED: 700 TOTAL WELL VOLUMES PUMPED:11.2

INITAL $\rho H: 7.0$ FNAL PH: 7.9

INITAL CONOUCTUTY ( $/ \mathrm{S} / \mathrm{cm}): 252$ FINAL CONDUCTUTY ( $\mathrm{HS} / \mathrm{cm}): 417$

DESCRIPTION OF INITAL TURBIOITY: ClOUdV

OESCRIPTION OF FNAL TURBIOITY: Clear

FNAL MEASURED TURBIDITY: $4.0 \mathrm{NTU}^{\prime} \mathrm{S}$

WEL APPROVED BY: R.C. Williams MMES

ODOR

OF WATER: None

WATER

OISCHARGED

GROUND SURFACE

a TANK TRUCK

口 STORAGE TANKS

TO:

D STORM SEMERS

DRUNS

口 OTHER

INITAL PRE-DEVZLOPMENT

WATER DEPTH: + +1.2 feet above ground surface

DEVELOPMENT OBSERVATIONS

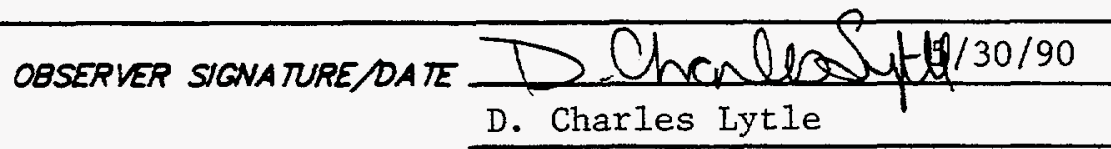


ERC / EDGE

Environmental

and Energy

Services Co.

WEL NO. 951

LOCA MON: WAG4

DATE: $5 / 17 / 90$

\section{MONITORING WELL DEVELOPMENT PROGRESS}

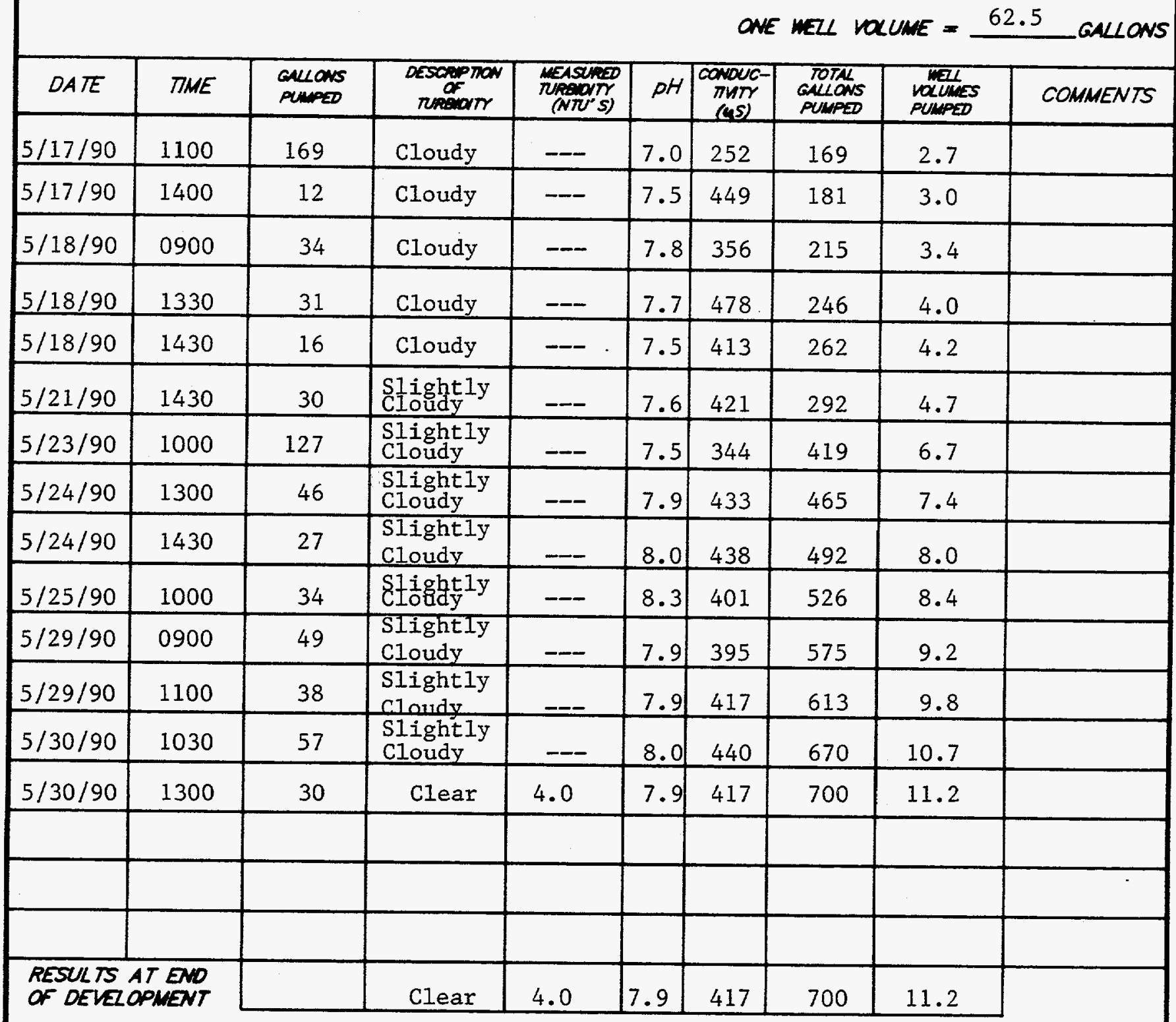

COMMENTS Good producer. Water remained clear even after surging.

Passed with 4.0 NTU's and moved to another hole. 


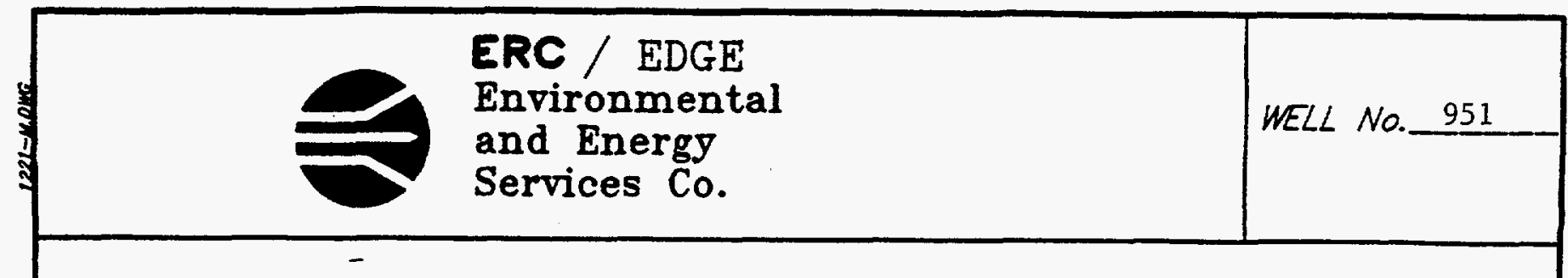

\title{
HYDRAULIC CONDUCTIVTY CALCULATIONS
}

\author{
PROGRAM SLUGT, VERSION 4.1 , NOV. 1986
}

THIS PROGRAM CALCULATES MEAN TRANSMISSIVITIES FROM

SLUG-TEST DATA BASED ON TWO ANALYTICAL APPROACHES:

(1) METHOD OF COOPER, BREDEHOEFT AND PAPADOPULOS, 1967 (ARTICLE IN VOL.3, NO.1 OF WRR ENTITLED

"RESPONSE OF A FINITE DIAMETER WELL TO AN INSTANTANEOUS CHARGE OF WATER")

(2) METHOD OF BOUWER AND RICE, 1976 (ARTICLE IN

VOL. 12, NO.3 OF WRR ENTITLED

"A SLUG TEST FOR DETERMINING HYDRAULIC CONDUCTIVITY OF UNCONFINED AQUIFERS WITH COMPLETELY OR PARTIALLY PENETRATING WELIS")

WELL NO.: 951

DATE OF TEST: $9-25-90$

PROJECT NO.: E221-002

CLIENT: MMES

SITE LOCATION: WAG-4

EDGE, INC. FIELD INVESTIGATOR: JAMES W. CARUTHERS

INPUT DATA ARE:

INNER CASING DIAMETER $=4.00$ INCHES

INNER SCREEN OR OPEN-HOLE DIAMETER $=4.00$ INCHES

DIAMETER OF DRILLED HOLE $=8.63$ INCHES

LENGTH OF SCREEN OR INTAKE PORTION $=20.80$ FEET

DEPTH FROM STATIC LEVEL TO BOTTOM OF SCREEN $=60.50$ FEET

THICKNESS OF SATURATED AQUIFER ZONE $=20.80 \mathrm{FEET}$

DEPTH TO STATIC WATER LEVEL BELOW REF. POINT $=1.00$ FEET

ESTIMATED POROSITY OF GRAVEL PACK $=.20$

FALLING-HEAD INDEX $=1$ ("I" IF FALLING,"0" IF RISING)

NUMBER OF DEPTH-TIME DATA POINTS $=32$

HO WAS COMPUTED FROM INTERCEPT OF PLOT OF LOG(H) VS. TIME SUCCESSIVE COMPUTED

VALUES FOR HO

(FEET)

2.9792

2.9804 


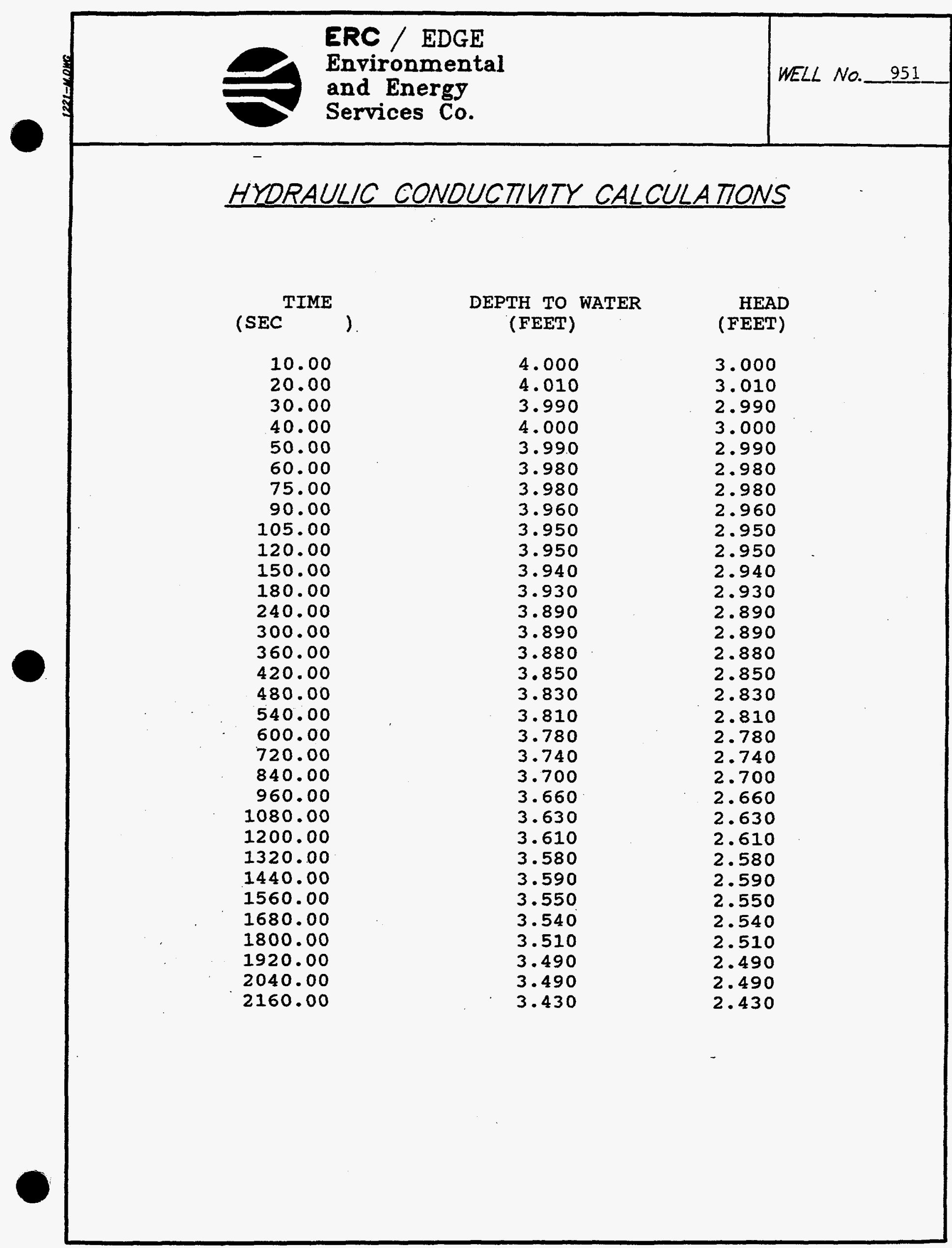

PAGE 15 of 17. 
ERC / EDGE

Environmental

and Energy

WELL NO. 951

Services Co.

\section{HYDRAULIC CONDUCTIVTY CALCULATIONS}

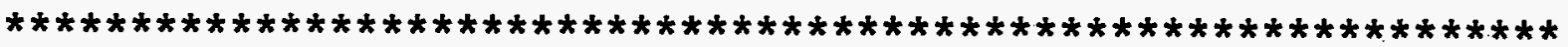

METHOD OF BOUWER AND RICE

COMPUTED RESULTS USING DIAMETER OF DRILLED HOLE:

$$
\text { PERMEABILITY }=2.51 \mathrm{E}-07 \mathrm{FT} / \mathrm{SEC} \quad=7.64 \mathrm{E}-06 \mathrm{CM} / \mathrm{SEC}
$$

TRANSMISSIVITY $=5.21 \mathrm{E}-06 \mathrm{FT} * 2 / \mathrm{SEC}$

COMPUTED RESULTS USING DIAMETER OF CASING AND SCREEN:

$$
\text { PERMEABILITY }=2.95 \mathrm{E}-07 \mathrm{FT} / \mathrm{SEC}=8.98 \mathrm{E}-06 \mathrm{CM} / \mathrm{SEC}
$$

TRANSMISSIVITY $=6.13 \mathrm{E}-06 \mathrm{FT} * 2 / \mathrm{SEC}$ 


\section{ERCE}

Environmental

and Energy

WELL NO. 951

Services Co.

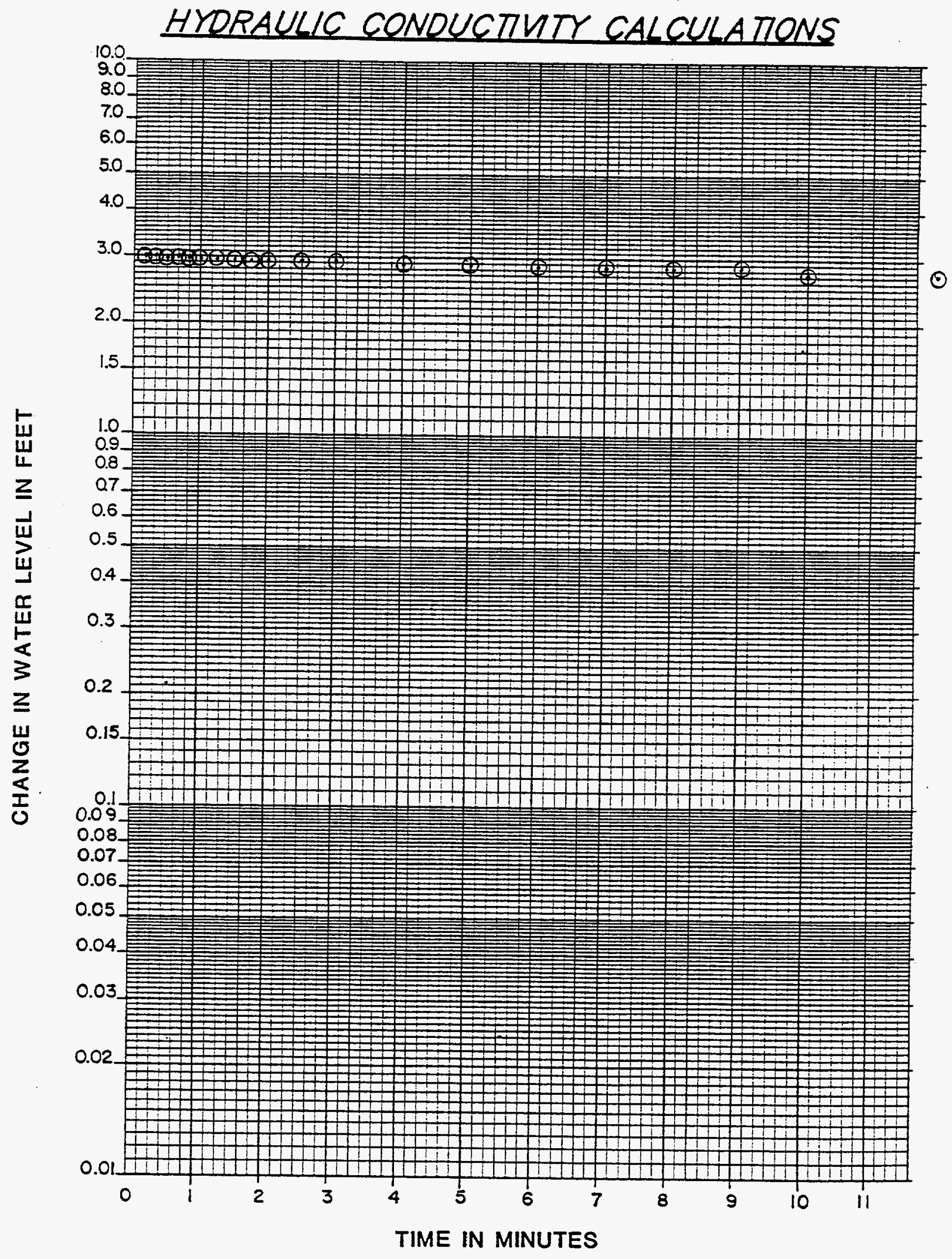

PAQE 17 of 17 


\subsection{General Information}

\subsection{Well Location}

Monitoring well number 952 is located in WAG 4. It is located north of WAG 4 approximately 75 feet north of Lagoon Road. The location is shown on ORNL drawing number C3E20004A075. Survey coordinates for this well are $N$ $19,597.7866$, E $28,670.7630$ (X-10 grid) or latitude $35^{\circ}-55^{\prime}-$ $02.82^{\prime \prime}$ and longitude $84^{\circ}-19^{\prime}-08.37^{\prime \prime}$. Coordinate data were provided by Martin Marietta Energy systems. The method used for conversion from $x-10$ grid to Tennessee-Lambert state Plane coordinates came from the publication "Tennessee Valley Authority Data Services Branch and Mapping Services Branch, Oak Ridge, Tennessee, DOE Plant Control, November 6, 1985, Field Book: EsS-3115, pp. 120." The latitude and longitude were calculated by Adams Craft Herz Walker Engineering, Inc., using methods from the U.S. Coast and Geodetic Survey Publication 62-4, "State Plane Coordinates by Automatic Data Processing."

\subsection{Drilling Information}

Well number 952 was drilled by A.I. Clark Drilling Services. A Gus Pech rig was used to drill this boring for monitor well installation under the operation of A.L. Clark III with the assistance of Ray clark. Drilling commenced on 9/23/87, and was finished on 9/24/87. Paragraph 2.4.1 includes a detailed discussion of the well installation and a well schematic is included on the well installation/ completion form. A synopsis of the drilling activity follows. This information was typed directly from field notes and was edited only when necessary for clarification. 


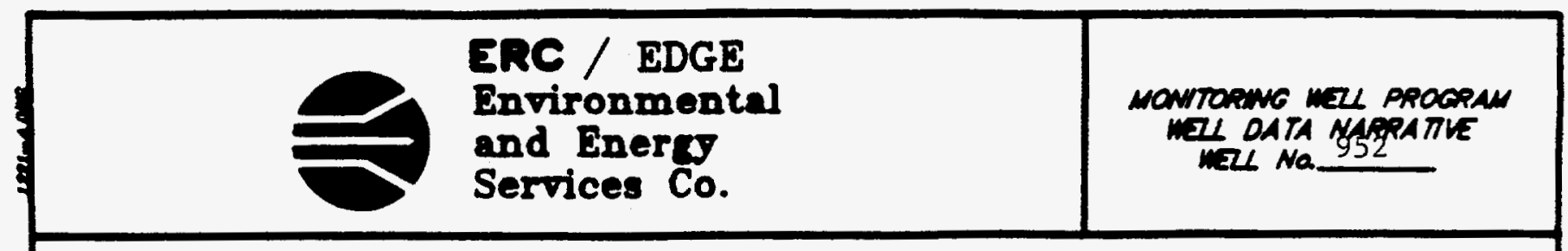

9/23/87: The Gus Peck drill rig and tools were steam cleaned and the rig was mobilized to the staked location and set up. The boring was split spooned from the surface to 1.4 feet. The boring was augered from the surface to 30.5 feet with $61 / 4$ inch augers. Two inch stainless steel screen, casing, sandpack and bentonite seal were installed.

9/24/87: The annulus was grouted from 1.5 feet up to the surface.

This well was logged by ERC Environmental and Energy Services Co., Inc., hydrogeologist Bryn D. Howze. All well construction materials and supplies were from Martin Marietta Energy Systems approved batches. The batch origin of individual items is shown on the included Monitoring well Materials Certification form.

2.0 Tachnical Information

\subsection{Decontamination Procedures}

The drilling rig, down hole tools, surface casing, stainless steel screen, stainless steel casing, centralizers, and stainless steel silt trap underwent the cleaning decontamination procedures outlined in the drilling specifications (Release specific Technical Directions for Regulatory Compliance Monitoring Wells Phase 1, Oak Ridge National Laboratory, Oak Ridge, w.o. K-4147, April 1987, pgs. 2-4). A checklist of the cleaned materials is included with this data package. 
ERC / EDGE

Environmental

and Enercs

Services Co.
MONTOANG WIH PROCPAW

WII DATA MARPATVE

in $\mathrm{Na} 952$

\subsection{Geology}

WAG 4 is located in Melton Valley which is in the Valley and Ridge Physiographic Province of East Tennessee. WAG 4 is underlain by shale, siltstone, and limestone of the Middle to Upper Cambrian Conasauga Group. The Conasauga Group in the oak Ridge area consists of six formations. They are, in ascending order, the Pumpkin Valley Shale, Rutledge Limestone, Rogersville Shale, Maryville Limestone, Nolichucky shale and the Maynardville Limestone. The Pumpkin Valley Shale and Rutledge Limestone underlie WAG 4. strike in and near WAG 4 ranges from $\mathrm{N} 85^{\circ} \mathrm{E}$ to $\mathrm{N} 15^{\circ} \mathrm{E}$ and dip varies from $27^{\circ}$ to vertical. These variations in strike and dip indicate that the conasauga has been deformed in the locale of WAG 4.

\subsection{Sample collection}

Two samples were collected during drilling, placed in ICHEM specialty cleaned glass containers, sealed and submitted to Sample Receiving, Analytical Chemistry Division, Bldg. 4500S, ORNL. Chain of custody forms for these samples are included with this data package. Soil sample 095251 was collected in the split spoon interval from 0.0 to 0.3 feet on $9 / 23 / 87$ and rock sample 0952R1 was collected at 30 feet.

\subsection{Installation and Development}

\subsubsection{Installation}

This was a Type A well. A 6-inch diameter boring was split spooned and augered from ground surface to a total depth of 
30.5 feet. A 2-inch diameter stainless steel screen with bottom cap was installed from 5.3 feet to 30.5 feet. A 2inch diameter stainless steel casing was installed above the screen from 5.3 feet to 2.88 feet above ground surface. A sandpack was then poured into the annular space from 30.5 to 3.5 feet, with a 2.0 foot bentonite pellet seal poured into the annular space above the sandpack from 1.5 to 3.5 feet. The annular space from the top of the bentonite seal to the surface was tremie grouted with a cement/bentonite slurry. A detailed schematic of the well is included on the well installation/completion form.

\subsubsection{Well Development}

Well number 952 was developed to remove drill cuttings, silt, and other fines. The monitoring well was developed using a Geoguard pump with an air compressor. All pumps were cleaned prior to use according to specified cleaning procedures (see Paragraph 2.1). The well was developed until a measured total of 523 gallons of water had been evacuated and the clarity of the discharge water was approved by the company representative. The final turbidity value measured at completion was 2.0 NTU's. A development form showing the exact method of development and other pertinent data is appended.

\subsubsection{Installation of Dedicated Monitoring well Pump}

After the well was developed, a Geoguard Model No. 5614 dedicated monitoring well pump was installed on 5/23/90 at a depth of 28.8 feet below ground surface. These pumps are decontaminated at American sigma and are sent prepackaged. A copy of the pump certification is kept on file at ORNL. 
ERC / EDGE

Environmental

and Enercy

Services Co.
MOMrTaRuv WIL PROCPAW

MZI DATA NGERATVE

\subsection{Hydraulic conductivity Testing}

Well number 952 was tested for the determination of hydraulic conductivity of the aquifer in the vicinity of the well screen. This was accomplished by instantaneously adding a known quantity of water to the monitoring well and measuring the recovery of the water level over time. The changing water levels were measured using a Druck 15 psi pressure transducer and an Omnidata Datapod II data recorder. The hydraulic conductivity value of $1.47 \times 10^{-5}$ $\mathrm{cm} / \mathrm{second}$ (shown as permeability on the hydraulic conductivity calculations printout attached) was calculated using the Bouwer and Rice method. A computer printout of the hydraulic conductivity calculations is included in this data package. 
ERC / EDGE

Environmental

and Energy

WELL NO._252

Services Co.

\section{PRE-DRILLING CHECKLIST FOR MONITORING WELLS}

PRE-DRILLING TASKS

1. EXCAVATION PERMIT OBTAINED.

2. ALL EQUIPMENT HAS BEEN CLEANED BEFORE ORILLNG.

3o. SCREEN ANO CASNGS HAVE BEEN WASHED, STEAMED, RINSED WIH DE-IONIZZD OR DISTLLED WATER, RINSED WTH ISOPROPN ALCOHOL WRAPPED WIH PROTECTVE COVERING AND STORED OFF THE GPOUND.

36. PRE-PACKAGED SCREENS, CASINGS AND CENTRALIZERS WERE USED.

4. WORK AREA FOR SAMPLE EXAMINATION COVERED $W T H$ CLEAN POK YETHRENE.

5. CLEAN KNIVES GLOVES, SAMPLE JARS AND LABEZS ON-HAND.

6. POL YETHRENE COVER IN PLACE OVER HOLE.

ADOITIONAL NOTES/OBSERVA HONS:
COMPLIANCE

DATE INITALS

9/23/87 BDH

$9 / 23 / 87$ BDH

$\mathrm{N} / \mathrm{A} \quad \mathrm{N} / \mathrm{A}$

9/24/87 BDH

9/23/87 BDH

9/23/87 BDH

BDH

OBSERVER SIGNATUREDATE $\frac{\text { Bry }}{\text { Bryn B. Howze }} 9 / 24 / 87$ 


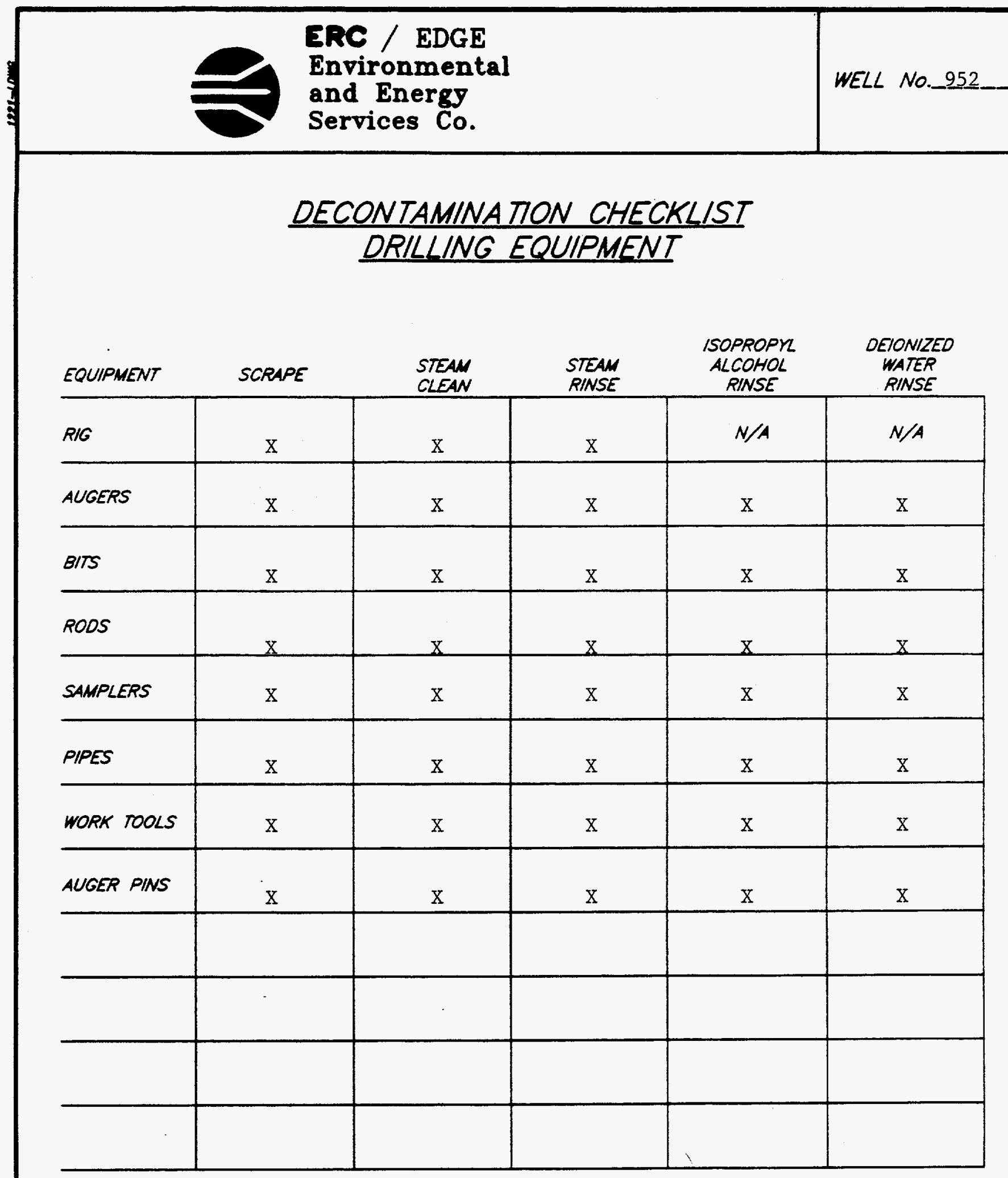

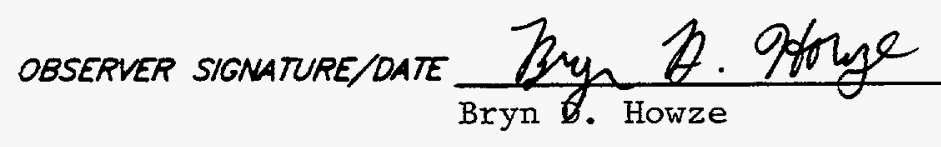
$9 / 23 / 87$ 


\begin{tabular}{|l|}
\hline ORNL MONITORING WELL LOG \\
\hline LOCA TON: SWSA 4 \\
ORILLER: $\frac{\text { Butch Clark }}{\text { RELPER: }}$ Ray Clark \\
ORILL:
\end{tabular}

TYPE DRILUNG: Auger

PAGE 1 of 1

OATE: START: $\quad 9 / 23 / 87$

FNISH: $9 / 24 / 87$

LOGGED BY: Bryn Howze

HEALTH PHYSHCST: Paul Eldridge

No. SAMPLES TAKEN: Two

LUBRICANT TPE: Molykote 1000

MPE: 1 Soil, 1 Rock (Saturated)

CONTAINWENT TYPE: Auger pan, plastic

THICKNESS OF SOLL (REFUSAL DEPTH): $1.4^{\prime}$

DEPTH DRILLED IN ROCK:

TOTAL DEPTH OF WELL:

\begin{tabular}{|c|c|c|c|c|}
\hline \multicolumn{2}{|c|}{$\begin{array}{l}\text { DEPTH } \\
\text { (FEET) } \\
\end{array}$} & \multirow{2}{*}{$\begin{array}{l}\text { SAMPLE } \\
\text { (NUMBER \& } \\
\text { INIERVAL) }\end{array}$} & \multirow{2}{*}{$\begin{array}{c}\text { PERCENT } \\
\text { RECOVERY } \\
\text { (SPUT SPOONS) }\end{array}$} & \multirow{2}{*}{ SOL BEDROCK DESCRIPTION } \\
\hline & & & & \\
\hline & & & & $3^{\prime}$ of soil removed by dozer for pad \\
\hline \multirow[t]{3}{*}{0.0} & 0.4 & $\begin{array}{l}095251 \\
0.0^{\top}-0.3^{\prime}\end{array}$ & $100 \%$ & Silt, light brown, mottled red, black, yellow, \\
\hline & & & & with rock fragments (shale, siltstone), roots, \\
\hline & & & & very stiff \\
\hline \multirow[t]{3}{*}{0.4} & 1.4 & & $88 \%$ & Silt, medium brown, mottled orange, yellow, \\
\hline & & & & black, abundant rock fragments (shale, silts \\
\hline & & & & stone) some roots, very stiff \\
\hline \multirow[t]{4}{*}{1.4} & 16.8 & & & Shale, highly weathered, very silty, some \\
\hline & & & & siltstone streaks, variegated, maroon, green, \\
\hline & & & & light brown, approximately $80^{\circ}$ dip to the \\
\hline & & & & southeast, micaceous, thin-bedded \\
\hline \multirow[t]{5}{*}{16.8} & 30.5 & $\begin{array}{l}0952 \mathrm{R} 1 \\
30.0 \\
\end{array}$ & & Interbedded shale, silty, greenish-maroon to \\
\hline & & & & steel gray and siltstone, light gray \\
\hline & & & & Hard drilling at $26.5^{\prime}$ \\
\hline & & & & Soft drilling at $28.0^{\prime}$ \\
\hline & 30.5 & & & Total Depth \\
\hline & & & & \\
\hline & & & & \\
\hline & & & & \\
\hline & & & & \\
\hline & & & & \\
\hline
\end{tabular}




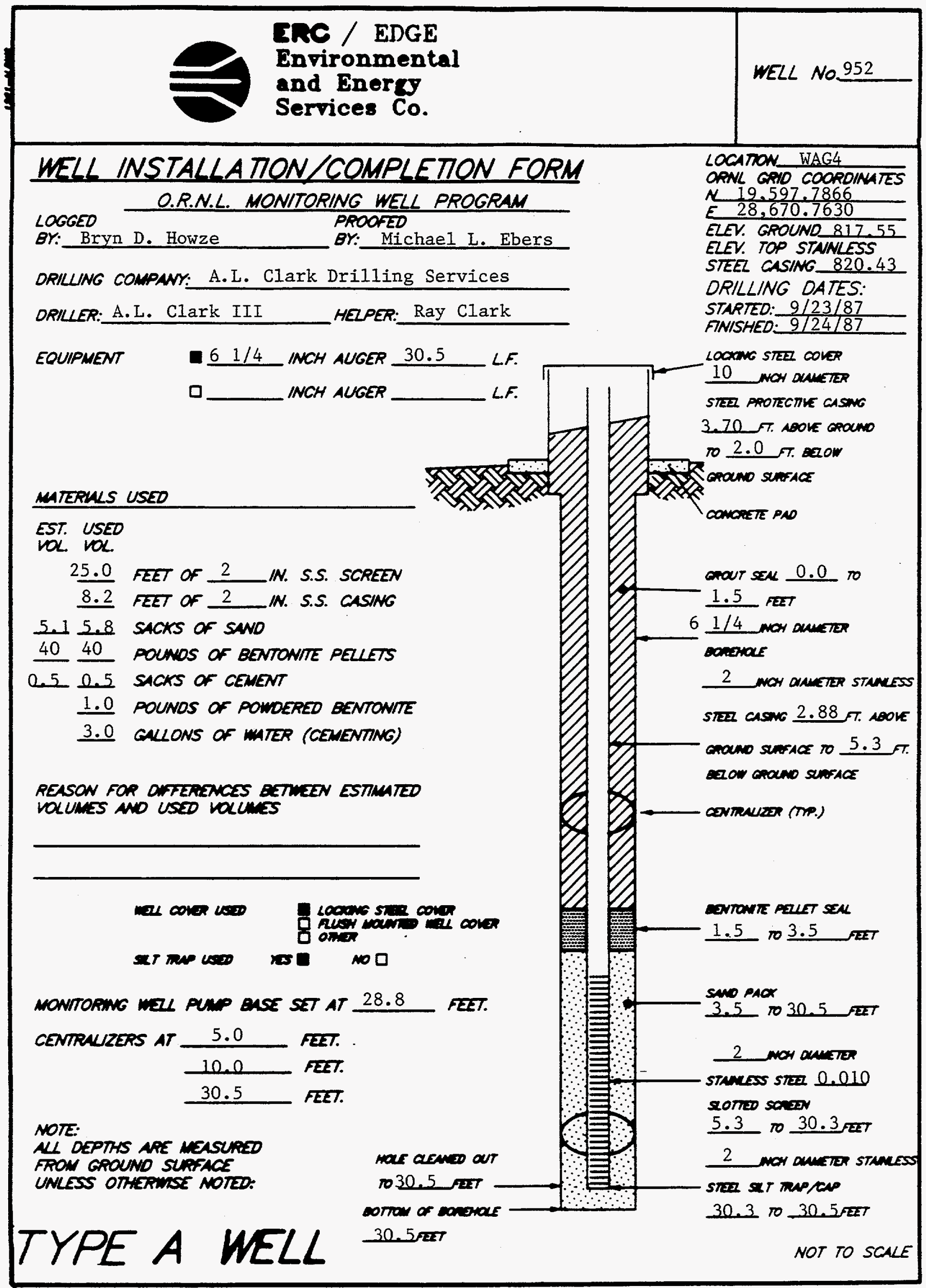




\section{ERC / EDGE}

Environmental

WELL NO. 952

and Energy

Services Co.

\section{MONITORING WELL MATERIALS CERTIFICATION}

\begin{tabular}{|c|c|c|}
\hline ITEM/MA TERIAL & DATE USED & BATCH NUMBER \\
\hline SANO & $9 / 24 / 87$ & 2 \\
\hline BENTONITE & $9 / 24 / 87$ & 2 \\
\hline (PREPACKAGED $\left.\begin{array}{cc}\text { YES } \\
\text { NO }\end{array}\right)$ & $9 / 24 / 87$ & 5 \\
\hline $\begin{array}{lll}\text { STAINLESS STEEL CASING (PREPACKAGED } & \text { YES } \\
\text { NO }\end{array}$ & $9 / 24 / 87$ & 5 \\
\hline $\begin{array}{lll}\text { STAINLESS STEEL CENTRALIZERS (PREPACKAGED } & \text { YES } \\
\text { NO }\end{array}$ & $9 / 24 / 87$ & 5 \\
\hline $\begin{array}{lll}\text { STAINLESS STEEL CAPS (PREPACKAGED } & \text { YES } \\
\text { NO }\end{array}$ & $9 / 24 / 37$ & 5 \\
\hline MONITORING WELL PUMP (PREPACKAGED $\begin{array}{c}\text { YES } \\
\text { NO }\end{array}$ & $5 / 23 / 90$ & 6 \\
\hline GROUT & $9 / 24 / 87$ & 11 \\
\hline WELL COVERS & & \\
\hline SURFACE CASING & $9 / 87$ & 1 \\
\hline
\end{tabular}

COMMENTS:

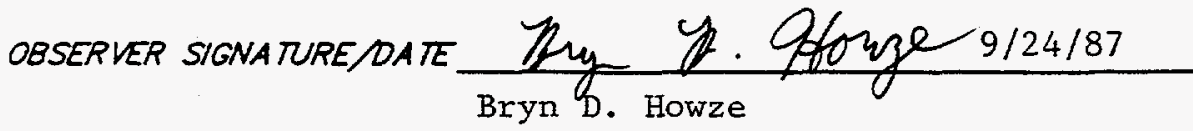


ERC / EDGE

Environmental

and Enerey

WELL NO.

\section{POST-MELL COMPLETION \\ CHECKLIST}

\section{POST-MELL COMPLETION TASKS}

$$
\begin{aligned}
& \text { COMPLIANCE } \\
& \text { DATE INITALS }
\end{aligned}
$$

1. MUO SCRAPED FROW AUGERS SAMPLERS, ANO ALL

$9 / 24 / 87$

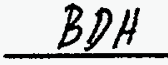
OTHER EOUIPMENT.

2. ALL WUO FRON RIG ANO EQUIPIENT SCRAPINGS ANO

9/24/87 BDH
CUTTNNOS OISPOSED OF IN ACCORDANCE WTH THE SPECATCA MON * PROVOED.

3 WEL DEVZLOED IN ACCOROANCE WTH THE SPECATCA MON PROMDED ANO OETAKS OF THE OEVELOPWENT ACTUTH RECOROED.

4. ORKLNG STE PROPERLY QLEANED UP AFTER COUPLETION OF MEL INSTALIATON.

- RELEASE SPECAFC TECHMCN DIRECTONS FOR RECULA TORY COMPUANCE WONTORMG WELS PHASE !, OAK RIDEE NATIONAL LABORATORY, OAK RIDCE M.O. K-4147, APRK 1987.

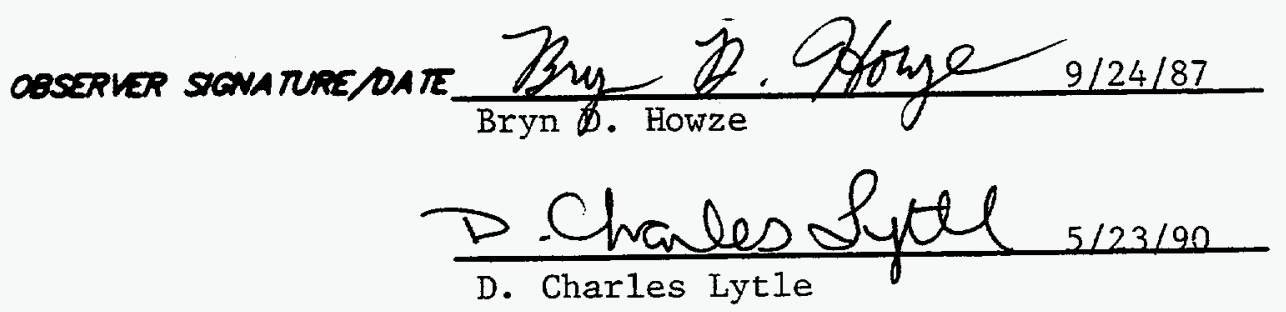




\section{MONITORING WELL DEVELOPMENT FORM}

DEVELOPMENT DETAILS

METHOD OF

DEVELOPMENT: Surging and pumping

DEVELOPMENT

BEGAN DATE: $\quad 5 / 11 / 90$ TME:

DEVELOPMENT

ENDING DATE: $\quad 5 / 23 / 90$

DEVELOPMENT

OBSERVED BY: D. Charles Lytle

ONE WELL VOLUME: 16,1_ GALLONS

TOTAL GALLONS PUMPED: 523 TOTAL WELL VOLUMES PUMPED: 32.5

INITAL PH: 8.1

INITAL CONOUCTVTY (HS/cm): 248 FNAL CONOUCTUTY $(\mu \mathrm{S} / \mathrm{cm}):-228$

OESCRIPTION OF INITIAL TURBIDITY: Milky

DESCRIPTION OF FNAL TURBIDITY:_Clear

FNAL MEASURED TURBIDITY: 2.0 NTU's

WELL APPROVED BY: R.C. WIIIIamS MMES

OOOR WATER: NONE

WATER GROUND SURFACE TINK TRUCK

DISCHARGED $\square$ STORM SEWERS I STORAGE TANKS

TO: $\quad$ D DRUMS $\square$ OTHER

INITAL PRE-DEVELOPMENT

WATER DEPTH: $\quad+3.1$ feet above ground surface

DEVELOPMENT OBSERVATIONS 
ERC / EDGE

Environmental

and Energy

Services Co.

mere No. 952

LOCA MON: WAG4

DATE: $5 / 11 / 90$

\section{MONITORING WELL DEVELOPMENT PROGRESS}

\begin{tabular}{|c|c|c|c|c|c|c|c|c|c|}
\hline$D A T E$ & TME & $\begin{array}{l}\text { QNLONS } \\
\text { PUIMPED }\end{array}$ & $\begin{array}{l}\text { DEscopton } \\
\text { of } \\
\text { rearar }\end{array}$ & 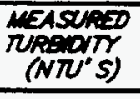 & $p H$ & $\begin{array}{l}\text { conouc- } \\
\text { murr } \\
\text { (us) }\end{array}$ & $\begin{array}{l}\text { TOTNK } \\
\text { GNúNs } \\
\text { Punped }\end{array}$ & $\begin{array}{l}\text { Mant } \\
\text { waxumes } \\
\text { Pumped }\end{array}$ & COMMENTS \\
\hline $5 / 11 / 90$ & 1300 & 10 & Milky & - & 8.1 & 248 & 10 & & \\
\hline $5 / 15 / 90$ & 0900 & 102 & Milky & -- & 7.8 & 276 & 112 & 7.0 & \\
\hline $5 / 15 / 90$ & 1100 & 18 & Milky & --- & 7.6 & 313 & 130 & 8.1 & \\
\hline $5 / 16 / 90$ & 1400 & 16 & Milky & --- & 7.6 & 263 & 146 & 9.1 & \\
\hline $5 / 17 / 90$ & 0900 & 83 & Milky & -- & 7.6 & 327 & 229 & 14.2 & \\
\hline $5 / 17 / 90$ & 1400 & 14 & Milky & -- & 7.5 & 247 & 243 & 15.1 & \\
\hline $5 / 18 / 90$ & 0900 & 42 & Cloudy & --- & 7.9 & 218 & 285 & 17.1 & \\
\hline $5 / 18 / 90$ & 1330 & 46 & $\begin{array}{l}\text { SlightIy } \\
\text { Cloudy }\end{array}$ & --- & 7.2 & 316 & 331 & 20.5 & \\
\hline $5 / 18 / 90$ & 1430 & 18 & $\begin{array}{l}\text { Slightly } \\
\text { Cloudy }\end{array}$ & --- & 7.5 & 235 & 349 & 22.0 & \\
\hline $5 / 21 / 90$ & 1430 & 72 & $\begin{array}{l}\text { Slightly } \\
\text { Cloudy }\end{array}$ & --- & 7.5 & 260 & 421 & 26.1 & \\
\hline $5 / 23 / 90$ & 1000 & 102 & Clear & 2.0 & 7.6 & 228 & 523 & 32.5 & \\
\hline & & & & & & & & & \\
\hline & & & & & & & & & \\
\hline & & & & & & & & & \\
\hline & & & & & & & & & \\
\hline $\begin{array}{l}\text { RESULTS } \\
\text { OF DEVE }\end{array}$ & ENO & & Clear & 2.0 & 7.6 & 228 & 523 & 32.5 & \\
\hline
\end{tabular}

COMMENTS

Good producer. Water remained clean after surging. Passed and moved to another hole.

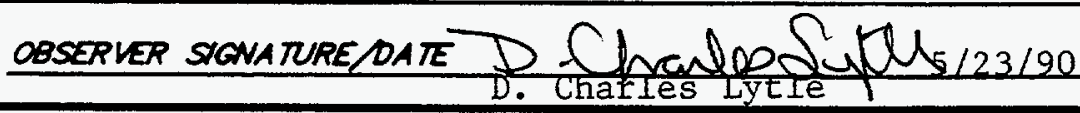

PAGE 13 of 19 


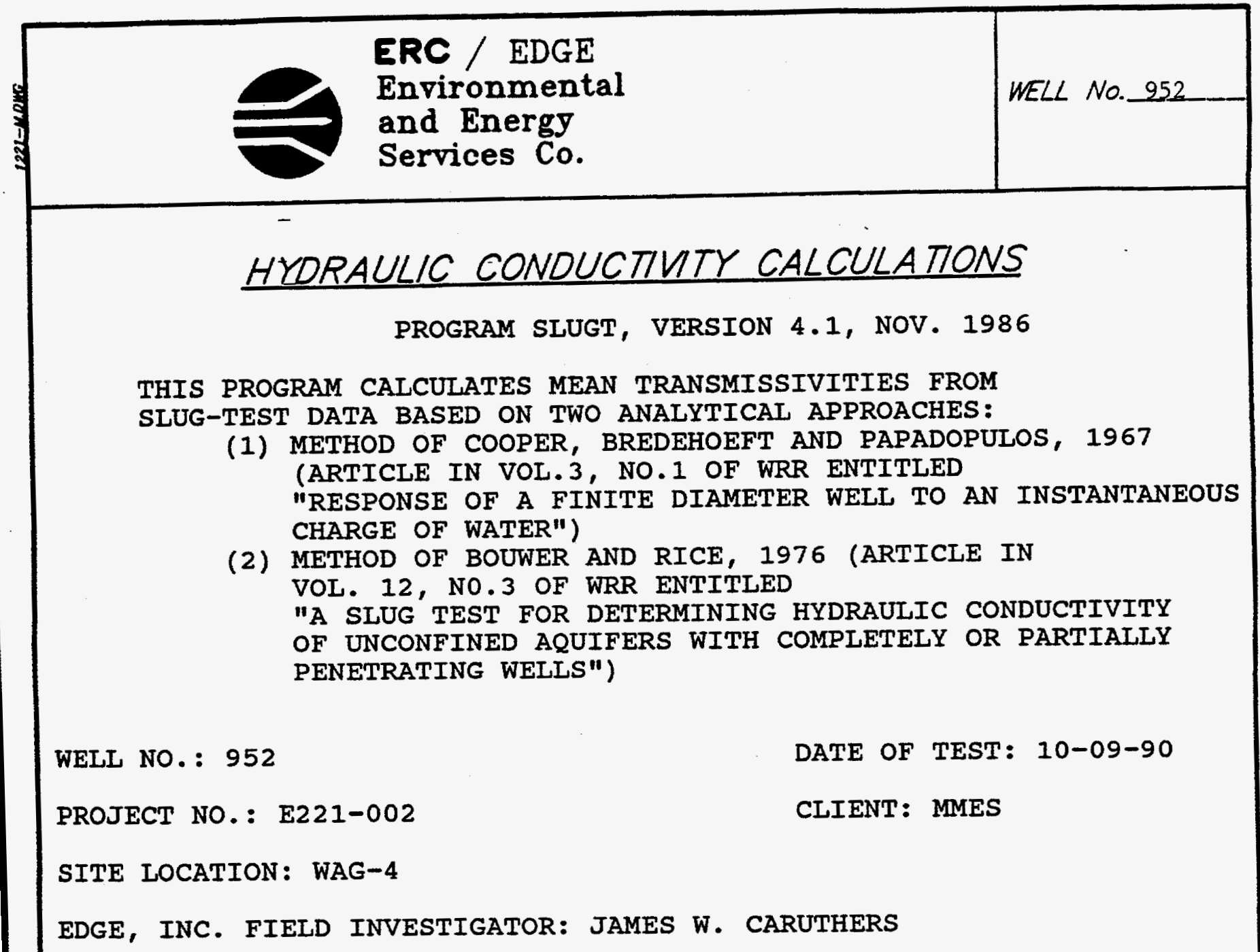

\section{INPUT DATA ARE:}

INNER CASING DIAMETER $=2.00$ INCHES

INNER SCREEN OR OPEN-HOLE DIAMETER $=2.00$ INCHES

DIAMETER OF DRILLED HOLE $=6.25$ INCHES

LENGTH OF SCREEN OR INTAKE PORTION $=25.00$ FEET

DEPTH FROM STATIC IEVEL TO BOTTOM OF SCREEN $=25.03$ FEET

THICKNESS OF SATURATED AQUIFER ZONE $=25.00$ FEET

DEPTH TO STATIC WATER LEVEL BELOW REF. POINT $=1.00$ FEET

ESTIMATED POROSITY OF GRAVEL PACK $=.20$

FALLING-HEAD INDEX $=1$ (" 1 " IF FALLING, "O" IF RISING)

NUMBER OF DEPTH-TIME DATA POINTS = 32

HO WAS COMPUTED FROM INTERCEPT OF PLOT OF LOG(H) VS. TIME

$$
\begin{gathered}
\text { SUCCESSIVE COMPUTED } \\
\text { VALUES FOR HO } \\
\text { (FEET) } \\
4.5163 \\
4.6162
\end{gathered}
$$




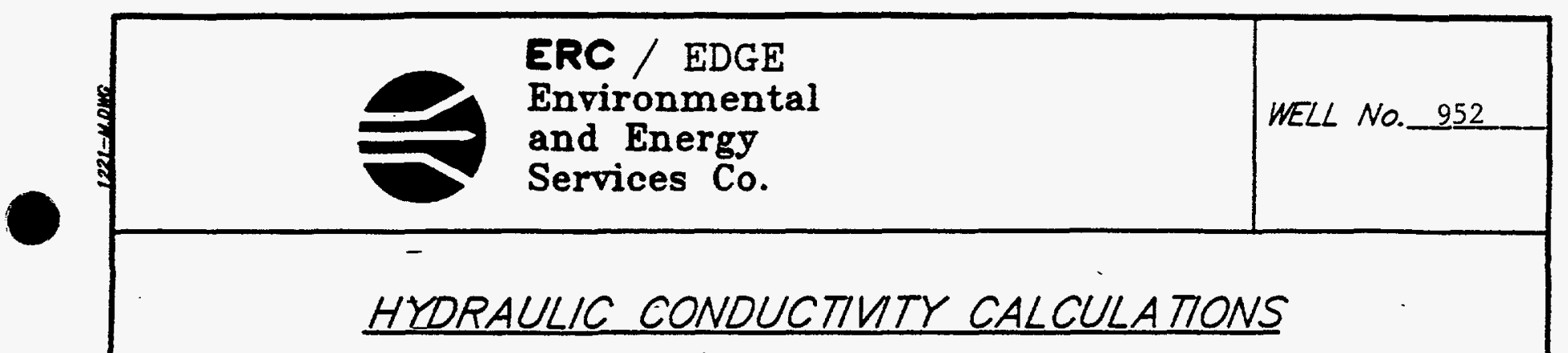

\begin{tabular}{|c|c|c|}
\hline$\left(\operatorname{SEC}^{\text {TIME }}\right)$ & $\begin{array}{l}\text { DEPTH TO WATER } \\
\text { (FEET) }\end{array}$ & $\begin{array}{r}\text { HEAD } \\
(\text { FEET) }\end{array}$ \\
\hline $\begin{array}{r}10.00 \\
20.00 \\
30.00 \\
40.00 \\
50.00 \\
60.00 \\
75.00 \\
90.00 \\
105.00 \\
120.00 \\
150.00 \\
180.00 \\
240.00 \\
300.00 \\
360.00 \\
420.00 \\
480.00\end{array}$ & $\begin{array}{l}7.660 \\
7.250 \\
6.940 \\
6.690 \\
6.460 \\
6.260 \\
5.990 \\
5.740 \\
5.530 \\
5.340 \\
4.890 \\
4.640 \\
4.240 \\
3.760 \\
3.560 \\
3.360 \\
3.210\end{array}$ & $\begin{array}{l}6.660 \\
6.250 \\
5.940 \\
5.690 \\
5.460 \\
5.260 \\
4.990 \\
4.740 \\
4.530 \\
4.340 \\
3.890 \\
3.640 \\
3.240 \\
2.760 \\
2.560 \\
2.360 \\
2.210\end{array}$ \\
\hline $\begin{array}{r}540.00 \\
600.00 \\
720.00 \\
840.00 \\
960.00 \\
1080.00 \\
1200.00 \\
1320.00 \\
1440.00 \\
1560.00 \\
1680.00 \\
1800.00 \\
1920.00 \\
2040.00 \\
2160.00\end{array}$ & $\begin{array}{l}3.090 \\
2.930 \\
2.640 \\
2.530 \\
2.390 \\
2.330 \\
2.240 \\
2.160 \\
2.090 \\
2.040 \\
1.950 \\
1.910 \\
1.890 \\
2.000 \\
2.000\end{array}$ & $\begin{array}{r}2.090 \\
1.930 \\
1.640 \\
1.530 \\
1.390 \\
1.330 \\
1.240 \\
1.160 \\
1.090 \\
1.040 \\
.950 \\
.910 \\
.890 \\
1.000 \\
1.000\end{array}$ \\
\hline
\end{tabular}




\section{HYDRAULIC CONDUCTIVTY CALCULATIONS}

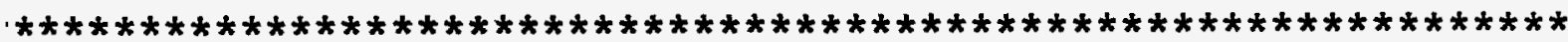
METHOD OF BOUWER AND RICE

COMPUTED RESULTS USING DIAMETER OF DRILLED HOLE:

$$
\begin{aligned}
& \text { PERMEABILITY }=4.81 \mathrm{E}-07 \mathrm{FT} / \mathrm{SEC}=1.47 \mathrm{E}-05 \mathrm{CM} / \mathrm{SEC} \\
& \text { TRANSMISSIVITY }=1.20 \mathrm{E}-05 \mathrm{FT} * 2 / \mathrm{SEC}
\end{aligned}
$$

COMPUTED RESULTS USING DIAMETER OF CASING AND SCREEN:

$$
\text { PERMEABILITY }=6.15 \mathrm{E}-07 \mathrm{FT} / \mathrm{SEC} \quad=1.87 \mathrm{E}-05 \mathrm{CM} / \mathrm{SEC}
$$

TRANSMISSIVITY $=1.54 \mathrm{E}-05 \mathrm{FT} * 2 / \mathrm{SEC}$ 


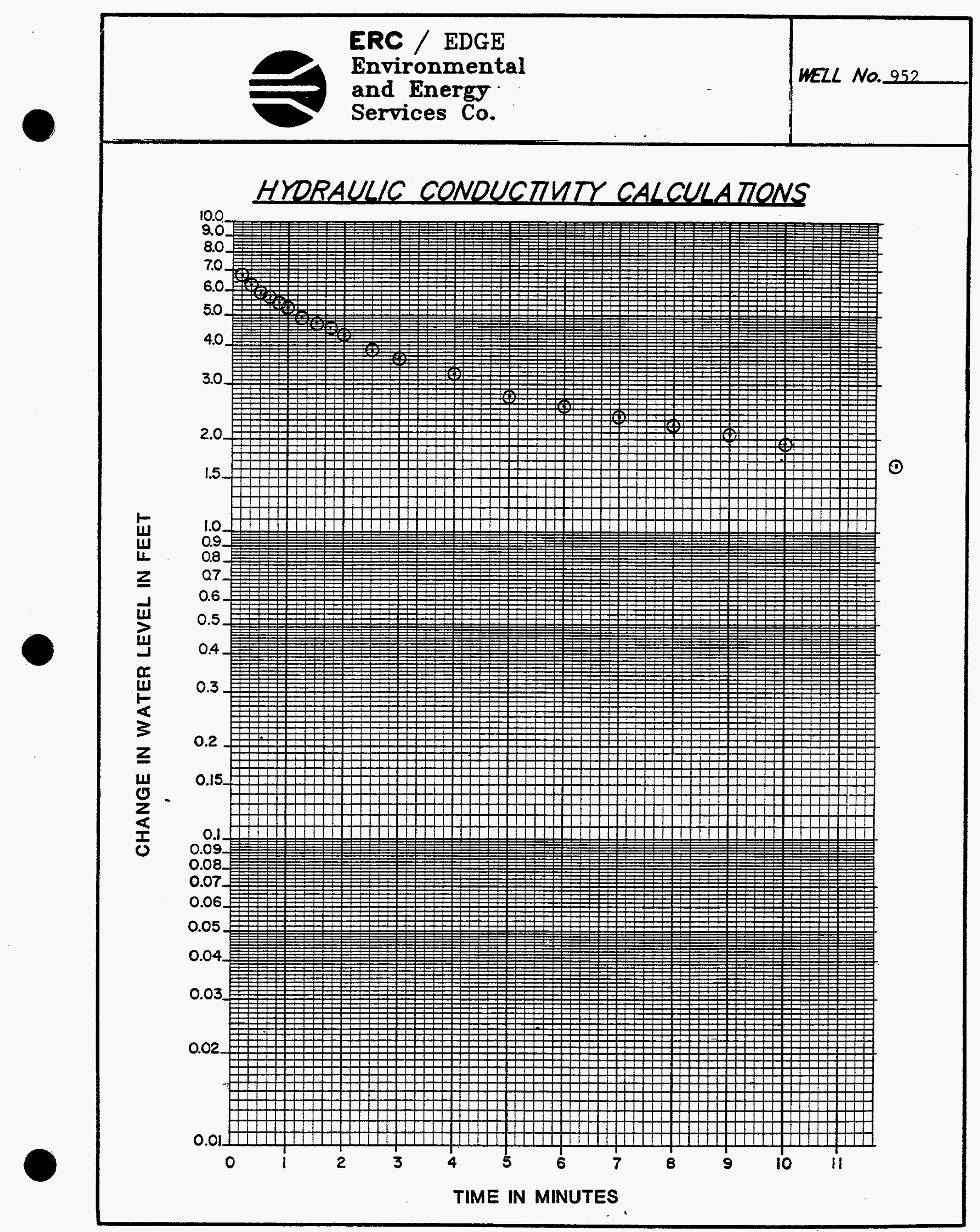




\begin{tabular}{|c|c|}
\hline WELL NO:: & LOCATION: \\
SAMPLER: & 5 WSA 4 \\
$0.0^{\prime}-0.3^{\prime}$
\end{tabular}

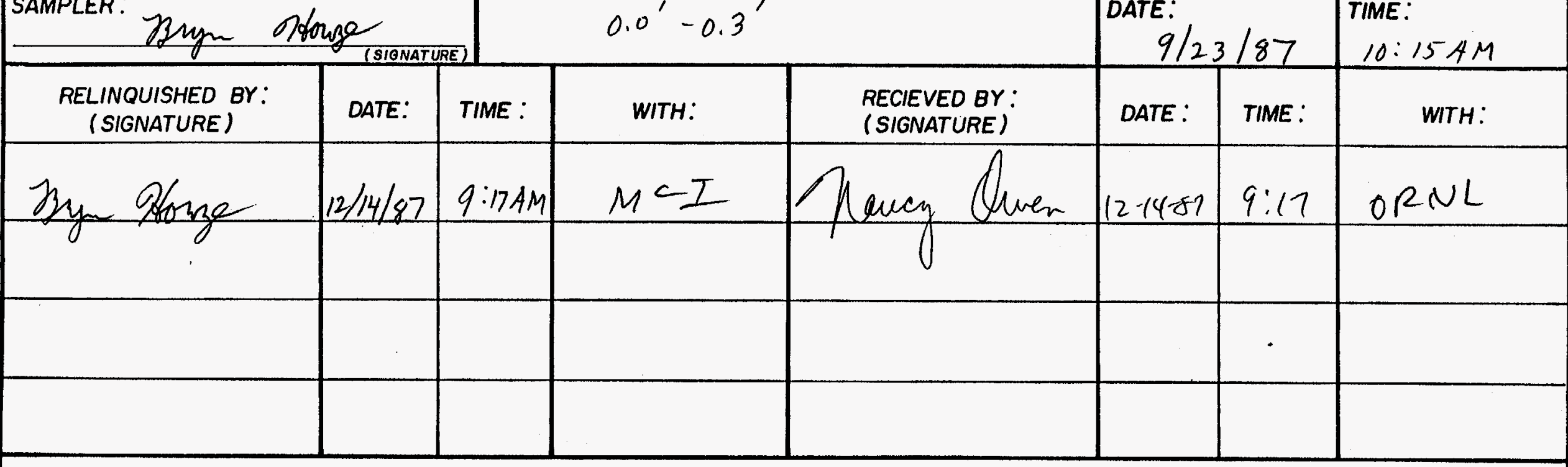

REMARKS: 
TI MCIICONSULTING ENGINEERS, INC.

NASHVILLE KNOXVILLE HUNTSVILLE LOUISVILLE (615) $966-9788$

WELL NO:: 952
LOCATION:

\section{CHAIN OF CUSTODY RECORD FOR \\ MARTIN MARIETTA ENERGY SYSTEMS \\ OAK RIDGE NATIONAL LABORATORY}

OAK RIDGE NATIONAL LABORATOF

$0952 R 1$

$$
\begin{aligned}
& S W 5 A, 4 \\
& \text { at } 30.0^{\prime}
\end{aligned}
$$

RELINQUISHED BY:

\begin{tabular}{|c|c|c|c|c|}
\hline $\begin{array}{l}\text { RELINQUISHED BY: } \\
\text { (SIGNATURE) }\end{array}$ & DATE: & TIME : & WITH: & $\begin{array}{l}\text { RECIEVED BY: } \\
\text { (SIGNATURE) }\end{array}$ \\
\hline Jop ofoune & $12 / 14 / 87$ & $9: 17 \mathrm{AN}$ & $M C T$ & Mancy Ouren \\
\hline & & & & 0 \\
\hline & & & & \\
\hline & & & & \\
\hline
\end{tabular}
(SIGNATURE)

at 30.0

REMARKS: 
ERC / EDGE

Environmental

and Enercy

Services Co.
MONTOPNG MZL PROARAN

WII OATA NARRATVE

MEL Na. 953

\subsection{General Information}

\subsection{We11 Location}

Monitoring well number 953 is located in WAG 4. It is located north of WAG 4 approximately 75 feet north of Lagoon Road. The location is shown on ORNL drawing number C3E20004A075. Survey coordinates for this well are $N$ $19,594.1315, \mathrm{E} 28,686.0885$ (X-10 grid) or latitude $35^{\circ}-55^{\prime}-$ $02.87^{\prime \prime}$ and longitude $84^{\circ}-19^{\prime}-08.19^{\prime \prime}$. Coordinate data were provided by Martin Marietta Energy systems. The method used for conversion from $x-10$ grid to Tennessee-Lambert state plane coordinates came from the publication "Tennessee Valley Authority Data Services Branch and Mapping Services Branch, Oak Ridge, Tennessee, DOE Plant Control, November 6, 1985, Field Book: Ess-3115, pp. 120." The latitude and longitude were calculated by Adams Craft Herz Walker Engineering, Inc., using methods from the U.S. Coast and Geodetic Survey Publication 62-4, "State Plane Coordinates by Automatic Data Processing."

\subsection{Drilling Information}

Well number 953 was drilled by A.L. Clark Drilling Services. A schramm Rotadrill rig was used to drill this boring for monitor well installation under the operation of A.I. Clark II with the assistance of Rick Pickel. Drilling commenced on 11/17/87, and was finished on 11/20/87. Paragraph 2.4.1 includes a detailed discussion of the well installation and a well schematic is included on the well 
installation/completion form. A synopsis of the drilling activity follows. This information was typed directly from field notes and was edited only when necessary for clarification.

11/12-87 The Schramm Rotadrill air rotary drill rig and to tools were steam cleaned.

11-13-87:

11/17/87: The rig was mobilized to the staked location and set up on plastic. Augered from surface to 20.5 feet with 14 inch augers.

11/18/87: Steam cleaned 26.9 feet of $103 / 4$ inch surface casing. Ran casing in boring and grouted annulus to the surface.

11/19/87: Rigging up to drill with containment.

11/20/87: Advanced boring from 26.5 feet to 70.0 feet with an 8 5/8 inch tricone bit. Cleaned hole and ran in stainless steel screen, casing, sandpack and bentonite seal. Grouted annulus from 41.0 feet to the surface.

This well was logged by ERC Environmental and Energy Services Co., Inc., hydrogeologist Michael L. Ebers. All well construction materials and supplies were from Martin Marietta Energy Systems approved batches. The batch origin of individual items is shown on the included Monitoring Well Materials Certification form. 
2.0 Technical Information

\subsection{Decontamination Procedures}

The drilling rig, down hole tools, surface casing, stainless steel screen, stainless steel casing, centralizers, and stainless steel silt trap underwent the cleaning decontamination procedures outlined in the drilling specifications (Release specific Technical Directions for Regulatory Compliance Monitoring Wells Phase 1. Oak Ridge National Laboratory, Oak Ridge, W.O. K-4147, April 1987, pgs. 2-4). A checklist of the cleaned materials is included with this data package.

\subsection{Geology}

WAG 4 is located in Melton Valley which is in the valley and Ridge Physiographic Province of East Tennessee. WAG 4 is underlain by shale, siltstone, and limestone of the Middle to Upper Cambrian Conasauga Group. The Conasauga Group in the Oak Ridge area consists of six formations. They are, in ascending order, the Pumpkin Valley shale, Rutledge Limestone, Rogersville Shale, Maryville Limestone, Nolichucky Shale and the Maynardville Limestone. The Pumpkin Valley Shale and Rutledge Limestone underlie WAG 4. strike in and near WAG 4 ranges from $\mathrm{N} 85^{\circ} \mathrm{E}$ to $\mathrm{N} 15^{\circ} \mathrm{E}$ and dip varies from $27^{\circ}$ to vertical. These variations in strike and dip indicate that the conasauga has been deformed in the locale of WAG 4. 
ERC / EDGE

Environmental

MONTORW WEL PROCPAN

and Enercy

Services Co.

\section{3 sample collection}

A drill water sample was collected from the water pump on the drill rig on 11/20/87. Analytical results for the drill water sample can be obtained from the Remedial Action Program data base at ORNL.

2.4 Installation and Development

\subsubsection{Installation}

This was a Type B we11. A 14-inch diameter boring was augered from the surface to 26.5 feet (auger refusal). A 10 3/4-inch diameter string of decontaminated steel surface casing was installed from 0.0 feet to 26.5 feet, sealed with a 1.5-foot bentonite pellet layer from 25.0 feet to 26.5 feet, and tremie grouted in place. The surface casing minimizes potential cross contamination between the regolith and bedrock water bearing zones. After the surface casing was installed, the air rotary method was used to drill an.8-inch diameter boring to a total depth of 70.5 feet. A 4-inch diameter stainless steel screen with bottom cap was installed from 49.6 feet to 69.9 feet. A 4inch diameter stainless steel casing was installed from the top of the screen at 49.6 feet and extended 2.3 feet above ground surface. A sandpack was then poured into the annular space from 69.9 feet up to 47.0 feet, with a 6.0foot bentonite seal from 41.0 to 47.0 feet. The annular space from the top of the bentonite seal to the surface was tremie grouted with a cement/bentonite slurry. A detailed schematic of the well is included on the well installation/completion form. 


\subsubsection{We11 Development}

Well number 953 was developed to remove drill cuttings, silt, and other fines. The monitoring well was developed using a Geoguard pump with an air compressor. All pumps were cleaned prior to use according to specified cleaning procedures (see Paragraph 2.1). The well was developed until a measured total of 349 gallons of water had been evacuated and the clarity of the discharge water was approved by the company representative. The final turbidity value measured at completion was 2.0 NTU's. A development form showing the exact method of development and other pertinent data is appended.

\subsubsection{Installation of Dedicated Honitoring Nell Pump}

After the well was developed, a Geoguard Model No. 5614 dedicated monitoring well pump was installed on 5/16/90 at a depth of 67.2 feet below ground surface. These pumps are decontaminated at American sigma and are sent prepackaged. A copy of the pump certification is kept on file at ORNL.

\subsection{Hydraulio Conductivity resting}

Well number 953 was tested for the determination of hydraulic conductivity of the aquifer in the vicinity of the well screen. This was accomplished by instantaneously adding a known quantity of water to the monitoring well and measuring the recovery of the water level over time. The changing water levels were measured using a Druck 15 psi pressure transducer and an Omnidata Datapod II data recorder. The hydraulic conductivity value of $3.41 \times 10^{-6}$ $\mathrm{cm} / \mathrm{second}$ (shown as permeability on the hydraulic 

ERC / EDGE

Environmental

and Enerey

WELL No. 953

\section{PRE-DRILLING CHECKLIST FOR MONITORING WELLS}

PRE-DRILLING TASKS

1. EXCAVATION PERMIT OBTAINED.

2. ALL EQUIPMENT HAS BEEN CLEANED BEFORE DRILLING.

30. SCREEN AND CASINGS HAVE BEEN WASHED, STEAMED, RINSED WTH DE-IONIZED OR OISTLLED WATER, RINSED COMPLIANCE WTH ISOPROPN ALCOHOL WRAPPED WTH PROTECTVE COVERING AND STORED OFF THE GROUND.

36. PRE-PACKAGED SCREENS, CASINGS AND CENTRALIZERS

$11 / 17 / 87$ ME WERE USED.

DATE INITALS

$11 / 17 / 87$ MLE

$11 / 17 / 87$ HWE

$\mathrm{N} / \mathrm{A} \quad \mathrm{N} / \mathrm{A}$

4. WORK AREA FOR SAMPLE EXAMINATION COVERED WTH CLEAN POL RETHRENE.

$11 / 17 / 87$ MME

5. CLEAN KNIVES, GOVES, SAMPLE JARS AND LABEZS

$11 / 17 / 87$ MUE ON-HAND. 11/17/87 WE

6. POLYETHRENE COVER IN PLACE OVER HOLE.

AOOIMONAL NOTES/OBSERVA TIONS:

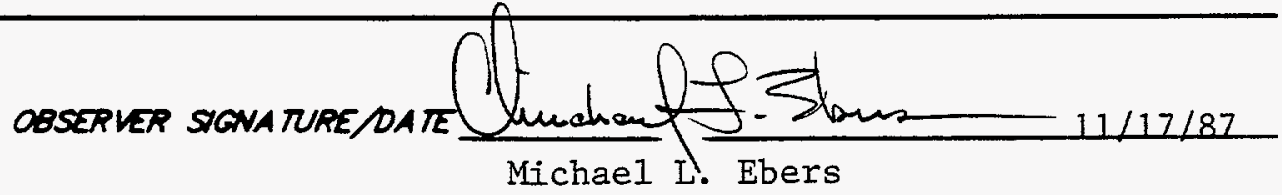


$\frac{\text { DECONTAMINATION CHECKLIST }}{\text { DRILLING EQUIPMENT }}$

\begin{tabular}{|c|c|c|c|c|c|}
\hline EQUIPMENT & SCRAPE & $\begin{array}{l}\text { STEAN } \\
\text { CLEAN }\end{array}$ & $\begin{array}{l}\text { STEAM } \\
\text { RINSE }\end{array}$ & $\begin{array}{c}\text { ISOPROPY } \\
\text { ALCOHOL } \\
\text { RINSE }\end{array}$ & $\begin{array}{c}\text { OEIONIZED } \\
\text { WATER } \\
\text { RINSE }\end{array}$ \\
\hline$R / G$ & $\mathrm{X}$ & $\mathrm{X}$ & $X$ & $N / A$ & $N / A$ \\
\hline AUGERS & $\mathrm{X}$ & $\mathrm{X}$ & $\mathrm{X}$ & $\mathrm{X}$ & $\mathrm{x}$ \\
\hline BITS & $\mathrm{x}$ & $\mathrm{x}$ & $\mathrm{X}$ & $x$ & $\mathrm{X}$ \\
\hline RODS & $\mathrm{X}$ & $\mathrm{x}$ & $x$ & $\mathrm{X}$ & $\mathrm{x}$ \\
\hline SAMPLERS & $\mathrm{X}$ & $\mathrm{x}$ & $\mathrm{X}$ & $\mathrm{X}$ & X \\
\hline PIPES & $\mathrm{X}$ & $X$ & $\mathrm{X}$ & $\mathrm{x}$ & $\mathrm{X}$ \\
\hline WORK TOOLS & $\mathrm{x}$ & $\mathrm{X}$ & $\mathrm{x}$ & $\mathrm{x}$ & $\mathrm{x}$ \\
\hline AUGER PINS & $\mathrm{X}$ & $\mathrm{X}$ & $\mathrm{X}$ & $\mathrm{x}$ & $\mathrm{X}$ \\
\hline & - & & & & \\
\hline & & & & & \\
\hline & & & & & \\
\hline
\end{tabular}

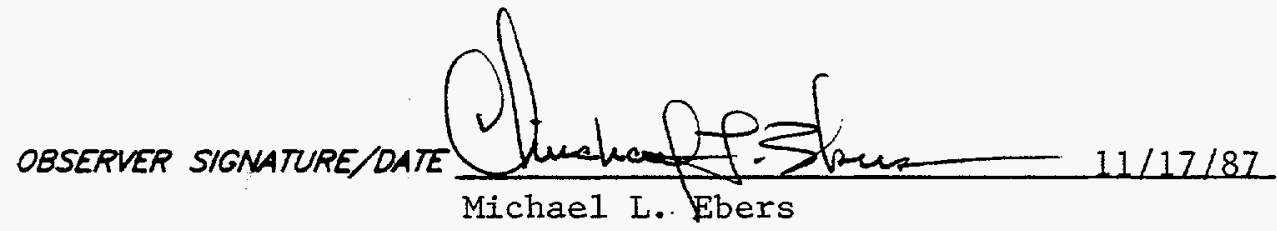




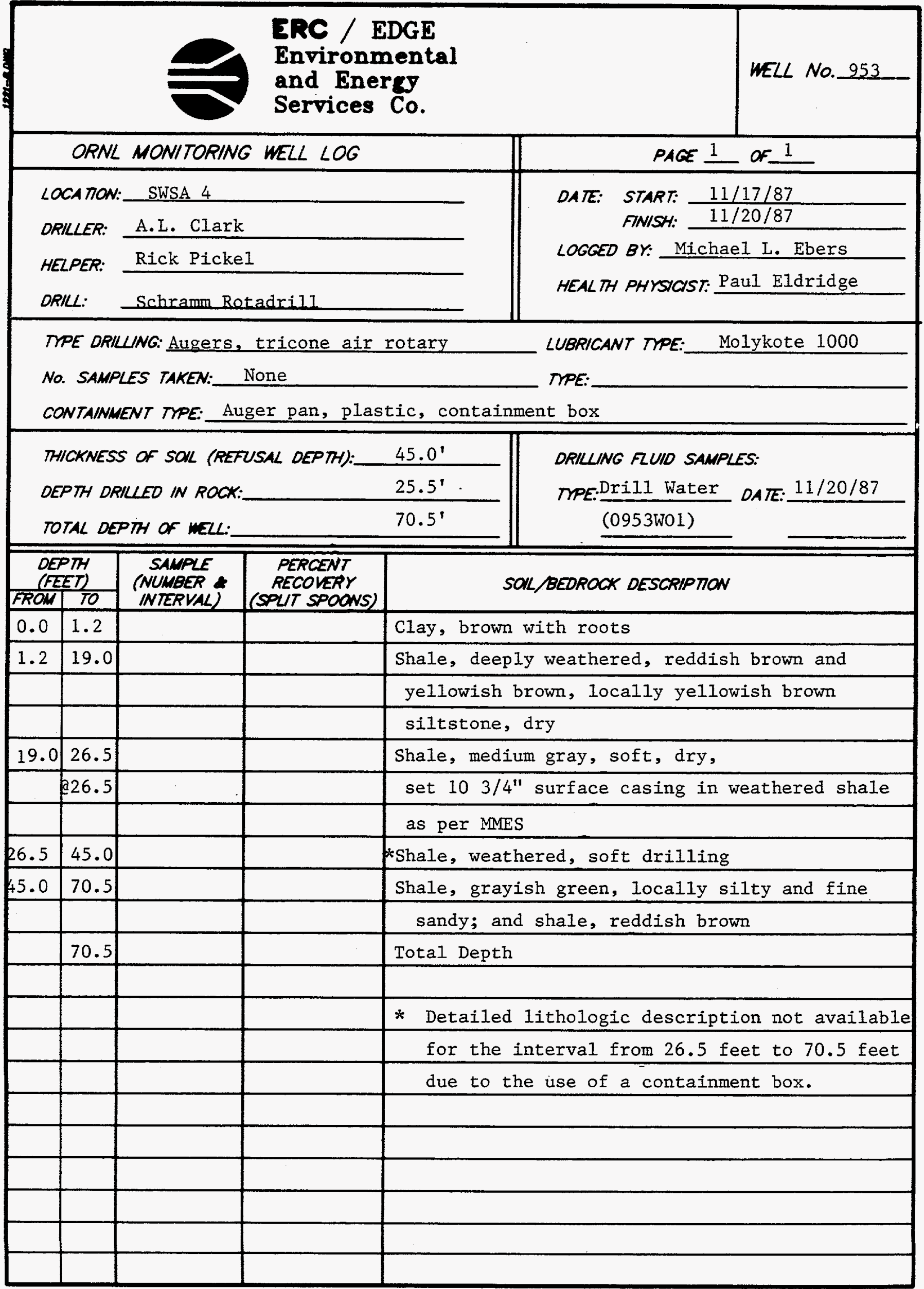




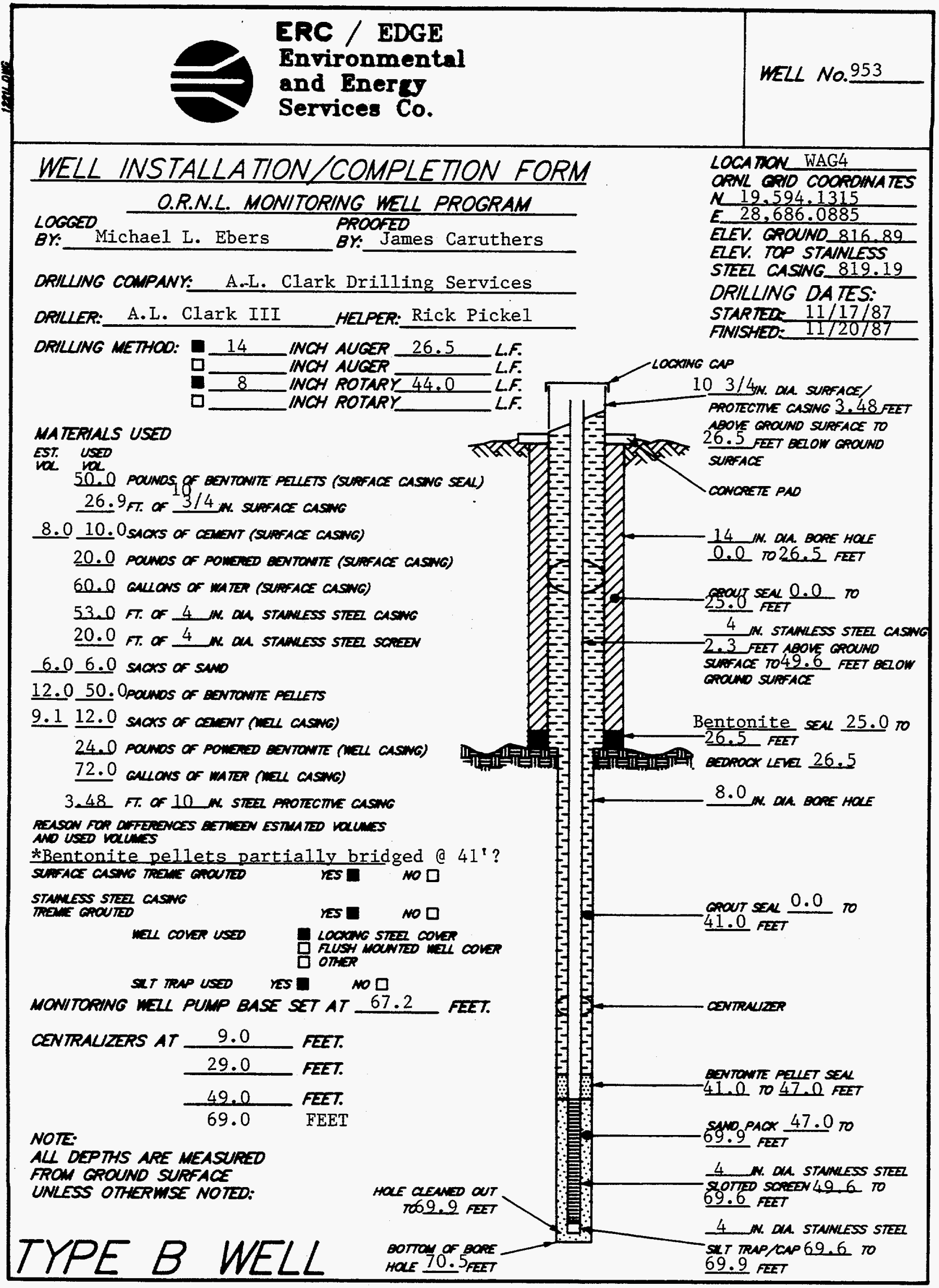

PAGE 10 of 20 
ERC / EDGE

Environmental

WELL No._. 953

and Energy

Services Co.

\section{MONITORING WELL MATERIALS CERTIFICATION}

ITEM/MA TERIAL

\begin{tabular}{|c|c|c|}
\hline & DATE USED & BATCH NUMBER \\
\hline & $11 / 20 / 87$ & 3 \\
\hline & $11 / 18 / 87$ & 3 \\
\hline & $11 / 20 / 87$ & 3 \\
\hline$\left(\begin{array}{c}\text { YES } \\
\text { NO }\end{array}\right)$ & $11 / 20 / 87$ & 5 \\
\hline$\left(\begin{array}{c}\text { YES } \\
\text { NO }\end{array}\right)$ & $11 / 20 / 87$ & 5 \\
\hline 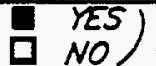 & $11 / 20 / 87$ & 5 \\
\hline$\left(\begin{array}{c}\text { ESS } \\
\text { NOO }\end{array}\right.$ & $11 / 20 / 87$ & 5 \\
\hline $\begin{array}{l}\text { Tes } \\
\text { NO }\end{array}$ & $5 / 16 / 90$ & 6 \\
\hline & $11 / 18 / 87$ & 14 \\
\hline & $11 / 20 / 87$ & 14 \\
\hline & & \\
\hline
\end{tabular}

MELL COVERS

SURFACE CASING

$11 / 18 / 87$

2

COMMENTS:

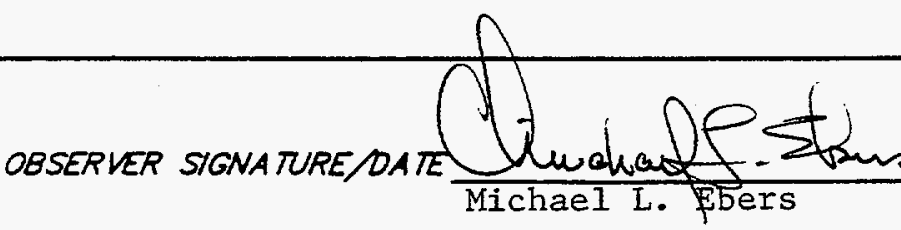

$11 / 20 / 87$

PAGE 11 of 20 


\section{\begin{tabular}{|l|l|}
\hline $\begin{array}{l}\text { ERC / EDGE } \\
\text { Environmental } \\
\text { and Energo } \\
\text { Services Co. }\end{array}$ & weLL No._953 \\
\hline
\end{tabular} \\ POST-MELL COMPLETION CHECKLIST}

\section{POST-WELL COMPLETION TASKS}

1. WUD SCRAPED FROM AUGERS SAMPLERS, AND ALL OTHER EQUIPMENT.

2. ALL WUD FRON AIG AND EOUPUENT SCRAPINGS ANO CUTTNAS DISPOSED OF IN ACCORDANCE IITH THE SPECAFCA ION PROMDED.

3 mEL DEVELORED IN ACCOROANCE WTH THE SOECATCA HON PROWOED AND DETAKS OF THE OEVRLOWENT ACTUTH RECOPOED.

4. ORHLWG STE PROPERLY CLEANED UP AFTER CONFLETION OF MIL INSTALA HON.

\section{$11 / 23 / 87$ HLE}

$11 / 23 / 87 \quad M U E$

$\underline{5 / 16 / 90}$

PCC

$11 / 23 / 87$

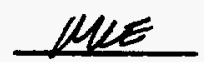

- REZEASE SPECAFC TECHMCN OIRECTONS FOR REQULATORY COMPUANCE NONITORNG MELS PHASE I. OAK RHOGE NATONAL LABORATOPY, OAK RIDEE M. K-4147, APRK 1987.

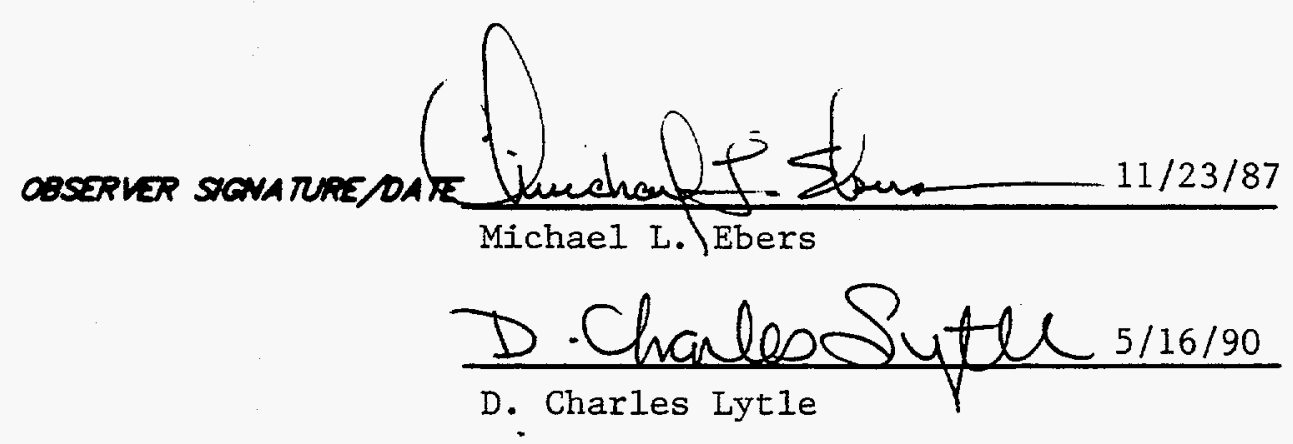


ERes

Environmental

and Energy

WELL No. 953

Services Co.

\section{MONITORING WELL \\ DEVELOPMENT FORM}

DEVELOPMENT DETAILS

METHOD OF

DEVELOPMENT: Surging and pumping

DEVELOPMENT

BEGAN DATE:

$5 / 11 / 90$

TME:

DEVELOPMENT

ENDING DATE: $\quad 5 / 16 / 90$

DEVELOPMENT

OBSERVED BY:

D. Charles Lytle

ONE WELL VOLUME: 63.2 GALLONS

TOTAL GALLONS PUMPED: 349 TOTAL WELL VOLUMES PUMPED: 5.5

INITAL PH: 7.7 FNAL PH: 7.9

INITAL CONDUCTUTY $(\mathrm{KS} / \mathrm{cm}): 576$ FNAL CONOUCTUTY $(\mathrm{\mu s} / \mathrm{cm}): 550$

DESCRIPTION OF INITAL RUREIDITY: Slightly Cloudy

DESCRIPTION OF FINAL TURBIDITY: Clear

FNAL MEASURED TURBIDITY: $2.0 \mathrm{NTU}^{\prime} \mathrm{S}$

WELL APPROVED BY: R.C. Williams MMES

\begin{tabular}{lll} 
ODOR & & \\
OE WATER: & None & \\
WATER & GROUND SURFACE & D TANK TRUCK \\
DISCHARGED & DTORN SEMERS & D STORAGE TANKS \\
TO: & DORUMS & OTHER \\
\hline
\end{tabular}

INITAL PRE-DEVELOPMENT

WATER DEPTH: +2.7 feet above ground surface

DEVELOPMENT OBSERVATIONS

OBSERVER SIGNATURE OATE D ChavloeSytts/16/90 D. Charles Lytle 
ERC / EDGE

Environmental

and Energy

Services Co.

weI NO. 953

LOCA MON: WAG4

DATE: $5 / 11 / 90$

\section{MONITORING WELL DEVELOPMENT PROGRESS}

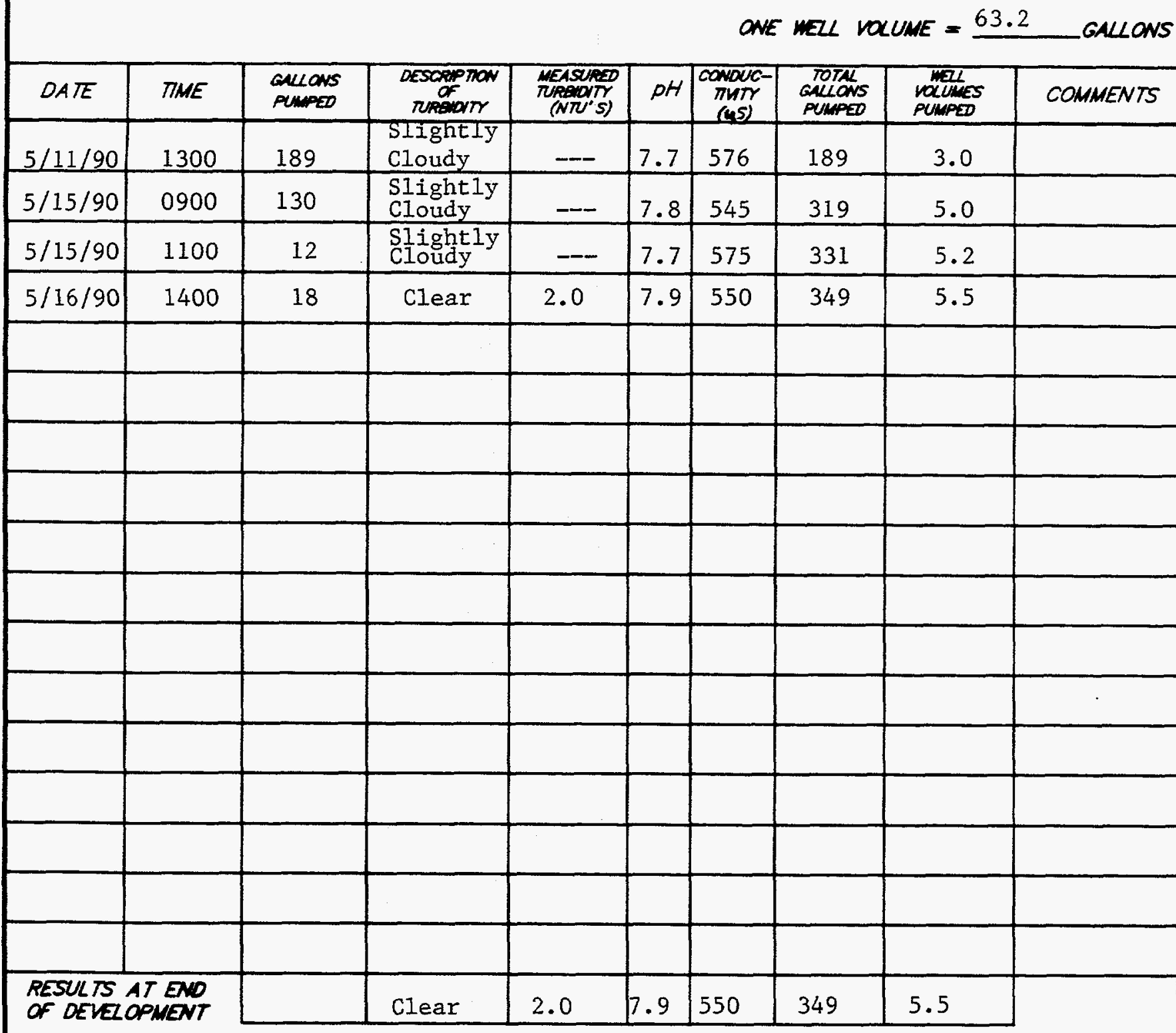

COMMENTS Good producer. Water remains clean even after surging. Passed

with 2.0 NTU's and moved to another hole. 


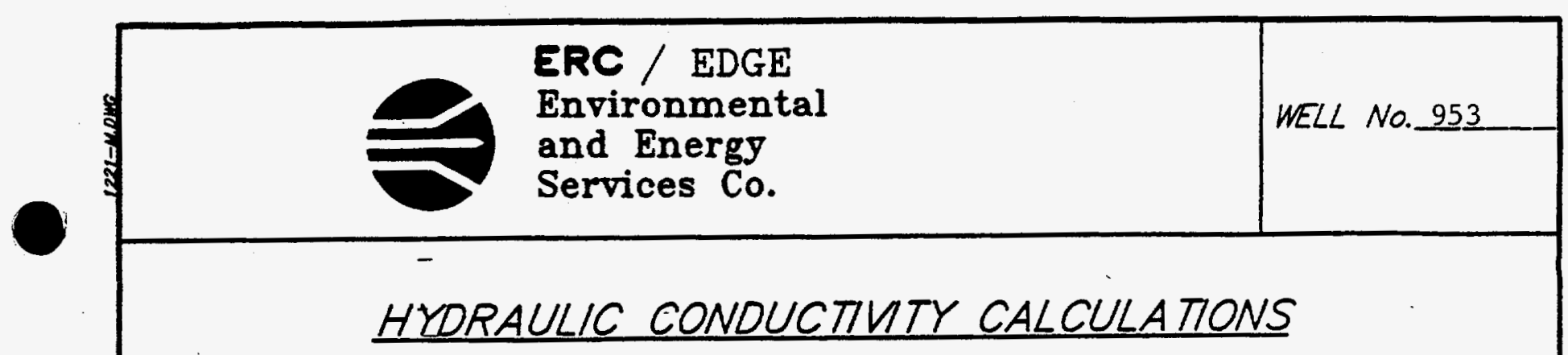

PROGRAM SLUGT, VERSION 4.1, NOV. 1986

THIS PROGRAM CALCULATES MEAN TRANSMISSIVITIES FROM

SLUG-TEST DATA BASED ON TWO ANALYTICAL APPROACHES:

(1) METHOD OF COOPER, BREDEHOEFT AND PAPADOPULOS, 1967 (ARTICLE IN VOL.3, NO.1 OF WRR ENTITLED

"RESPONSE OF A FINITE DIAMETER WELL TO AN INSTANTANEOUS CHARGE OF WATER")

(2) METHOD OF BOUWER AND RICE, 1976 (ARTICLE IN

VOL. 12, NO.3 OF WRR ENTITLED

"A SLUG TEST FOR DETERMINING HYDRAULIC CONDUCTIVITY

OF UNCONFINED AQUIFERS WITH COMPLETELY OR PARTIALLY PENETRATING WELLS")

WELL NO.: 953

DATE OF TEST: $10-09-90$

PROJECT NO.: E221-002

CLIENT: MMES

SITE LOCATION: WAG-4

EDGE, INC. FIELD INVESTIGATOR: JAMES W. CARUTHERS

INPUT DATA ARE:

INNER CASING DIAMETER $=4.00$ INCHES

INNER SCREEN OR OPEN-HOLE DIAMETER = 4.00 INCHES

DIAMETER OF DRILLED HOLE $=8.00$ INCHES

LENGTH OF SCREEN OR INTAKE PORTION $=20.00$ FEET

DEPTH FROM STATIC LEVEI TO BOTTOM OF SCREEN $=66.80$ FEET

THICKNESS OF SATURATED AQUIFER ZONE $=20.00$ FEET

DEPTH TO STATIC WATER LEVEL BELOW REF. POINT $=1.00$ FEET

ESTIMATED POROSITY OF GRAVEL PACK $=.20$

FALIING-HEAD INDEX = 1 ("1" IF FALLING,"O" IF RISING)

NUMBER OF DEPTH-TIME DATA POINTS = 32

HO WAS COMPUTED FROM INTERCEPT OF PLOT OF LOG(H) VS. TIME

SUCCESSIVE COMPUTED

VALUES FOR HO

(FEET)

2.7399

2.7405

PAGE 15 OF 20. 
ERC / EDGE

Environmental

and Energy

WELL NO. 953

Services Co.

HYDRAULIC CONDUCTIVTY CALCULATIONS

\begin{tabular}{|c|c|c|}
\hline$\left(\operatorname{SEC}^{\text {TIME }}\right)$ & $\begin{array}{l}\text { DEPTH TO WATER } \\
\text { (FEET) }\end{array}$ & $\begin{array}{r}\text { HEAD } \\
\text { (FEET) }\end{array}$ \\
\hline $\begin{array}{r}10.00 \\
20.00 \\
30.00 \\
40.00 \\
50.00 \\
60.00 \\
75.00 \\
90.00 \\
105.00 \\
120.00 \\
150.00 \\
180.00 \\
240.00 \\
300.00 \\
360.00 \\
420.00 \\
480.00\end{array}$ & $\begin{array}{l}3.750 \\
3.730 \\
3.750 \\
3.730 \\
3.730 \\
3.750 \\
3.750 \\
3.730 \\
3.720 \\
3.730 \\
3.730 \\
3.720 \\
3.720 \\
3.710 \\
3.710 \\
3.690 \\
3.690\end{array}$ & $\begin{array}{l}2.750 \\
2.730 \\
2.750 \\
2.730 \\
2.730 \\
2.750 \\
2.750 \\
2.730 \\
2.720 \\
2.730 \\
2.730 \\
2.720 \\
2.720 \\
2.710 \\
2.710 \\
2.690 \\
2.690\end{array}$ \\
\hline $\begin{array}{r}540.00 \\
600.00 \\
720.00 \\
840.00 \\
960.00 \\
1080.00 \\
1200.00 \\
1320.00 \\
1440.00 \\
1560.00 \\
1680.00 \\
1800.00 \\
1920.00 \\
2040.00 \\
2160.00\end{array}$ & $\begin{array}{l}3.690 \\
3.650 \\
3.630 \\
3.610 \\
3.630 \\
3.600 \\
3.590 \\
3.610 \\
3.610 \\
3.580 \\
3.540 \\
3.530 \\
3.540 \\
3.540 \\
3.520\end{array}$ & $\begin{array}{l}2.690 \\
2.650 \\
2.630 \\
2.610 \\
2.630 \\
2.600 \\
2.590 \\
2.610 \\
2.610 \\
2.580 \\
2.540 \\
2.530 \\
2.540 \\
2.540 \\
2.520\end{array}$ \\
\hline
\end{tabular}


ERT / EDGE

Environmental

and Energy

WELL NO. 953

Services Co.

HYDRAULIC CONDUCTIVTY CALCULATIONS

METHOD OF BOUWER AND RICE

COMPUTED RESULTS USING DIAMETER OF DRILLED HOLE:

PERMEABILITY $=1.12 \mathrm{E}-07 \mathrm{FT} / \mathrm{SEC}=3.41 \mathrm{E}-06 \mathrm{CM} / \mathrm{SEC}$

TRANSMISSIVITY $=2.24 \mathrm{E}-06 \mathrm{FT} * * 2 / \mathrm{SEC}$

COMPUTED RESULTS USING DIAMETER OF CASING AND SCREEN:

PERMEABILITY $=1.29 \mathrm{E}-07 \mathrm{FT} / \mathrm{SEC}=3.94 \mathrm{E}-06 \mathrm{CM} / \mathrm{SEC}$

TRANSMISSIVITY $=2.58 \mathrm{E}-06 \mathrm{FT} * * 2 / \mathrm{SEC}$

PAGE 17 OF 20 


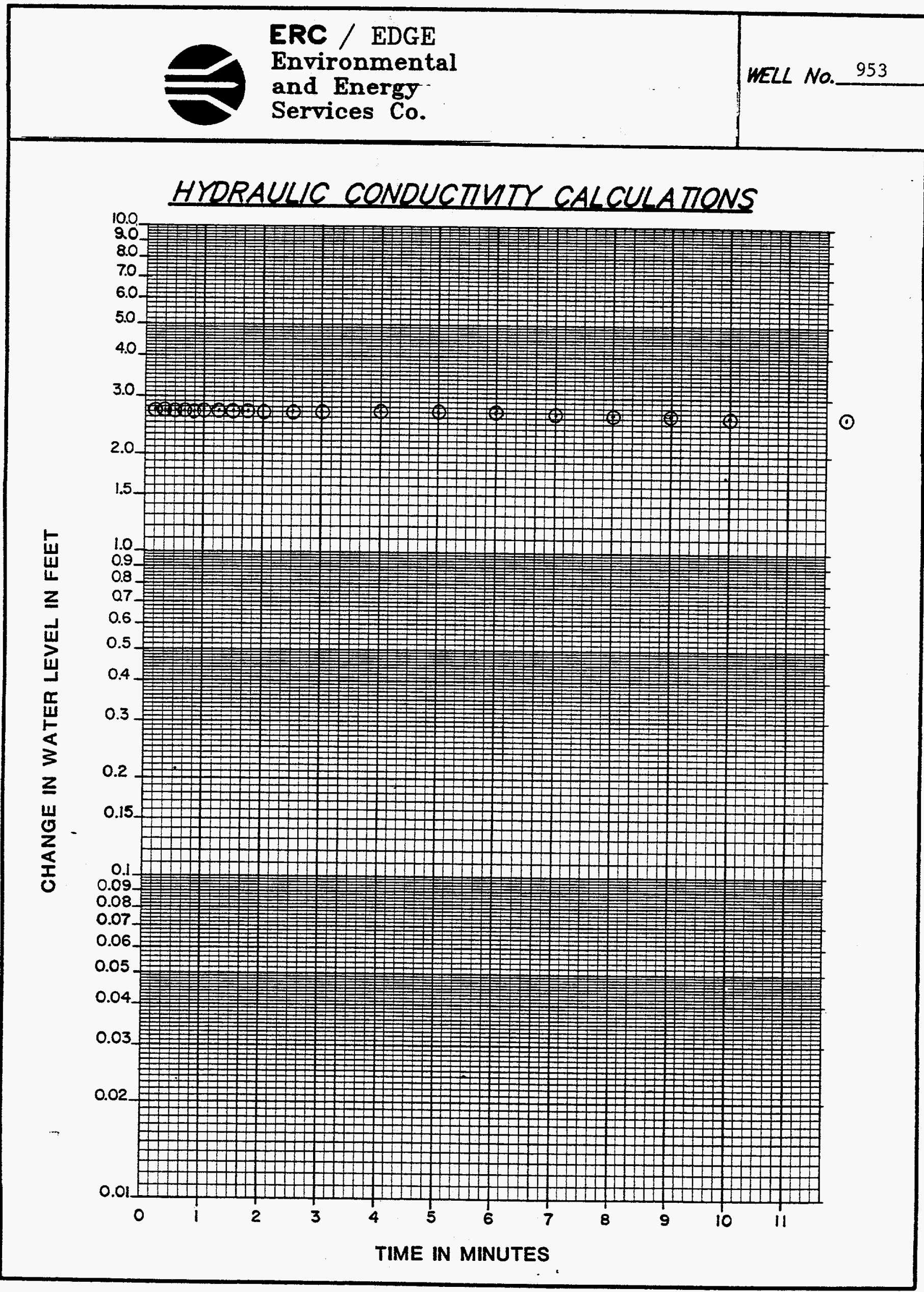

PACE 18 or 20 
Angineering, Design \& Geosciences Group, Inc. WELL NO. 953 725 Pellissippi Parkway

P.O. Box 23010 Knoxville, Tn 37933-1010 (615)966-9788

AREA: : SWSA4

NONCONFORMANCE REPORT

ISSUE OATE: $11 / 28 / 87$

DATE OF NONCONFORMANCE: $11 / 20 / 87$

DESCRIPTION OF NONCONFORMANCE:

Annular space above bentonite seal was grout $11 / 2$ hours after bentonite seal was installed. Refer to Release Specific Technical Directions for Regulatory

Compliance Monitoring Wel1s, Phase I, 0.R.N.L., W.0. K-4147, Apri1, 1987, page 8, last paragraph. This reference states that initial grouting shall be done no sooner than 12 hours after the bentonite seal is installed.

POSSIBLE DETRIMENTAL EFFECTS TO WEZL QUALITY:

Minima1. Bentonite seal had, most likely, setup in $11 / 2$ hours.

COMMENTS:

\begin{tabular}{|l|c|}
\hline $\begin{array}{l}\text { OBSERVER OF NONCONFORMANCE: } \\
\text { Michael L. Ebers }\end{array}$ & $\begin{array}{c}\text { DATE: } \\
11 / 20 / 87\end{array}$ \\
\hline $\begin{array}{l}\text { REPORTED BY: } \\
\text { Michael L. Ebers }\end{array}$ & DATE: \\
\hline $\begin{array}{l}\text { DISTRIBUTON } \\
\text { PROJECT MANAGER: }\end{array}$ & DATE SUBMITIED: \\
Jill Mortimore & $11 / 24 / 87$ \\
\hline $\begin{array}{l}\text { CONSTRUCTON } \\
\text { ENGINEER: } \quad \text { Steve Laman }\end{array}$ & OATE SUBMITIED: \\
\end{tabular}

PAGE 19 OF 20 . 


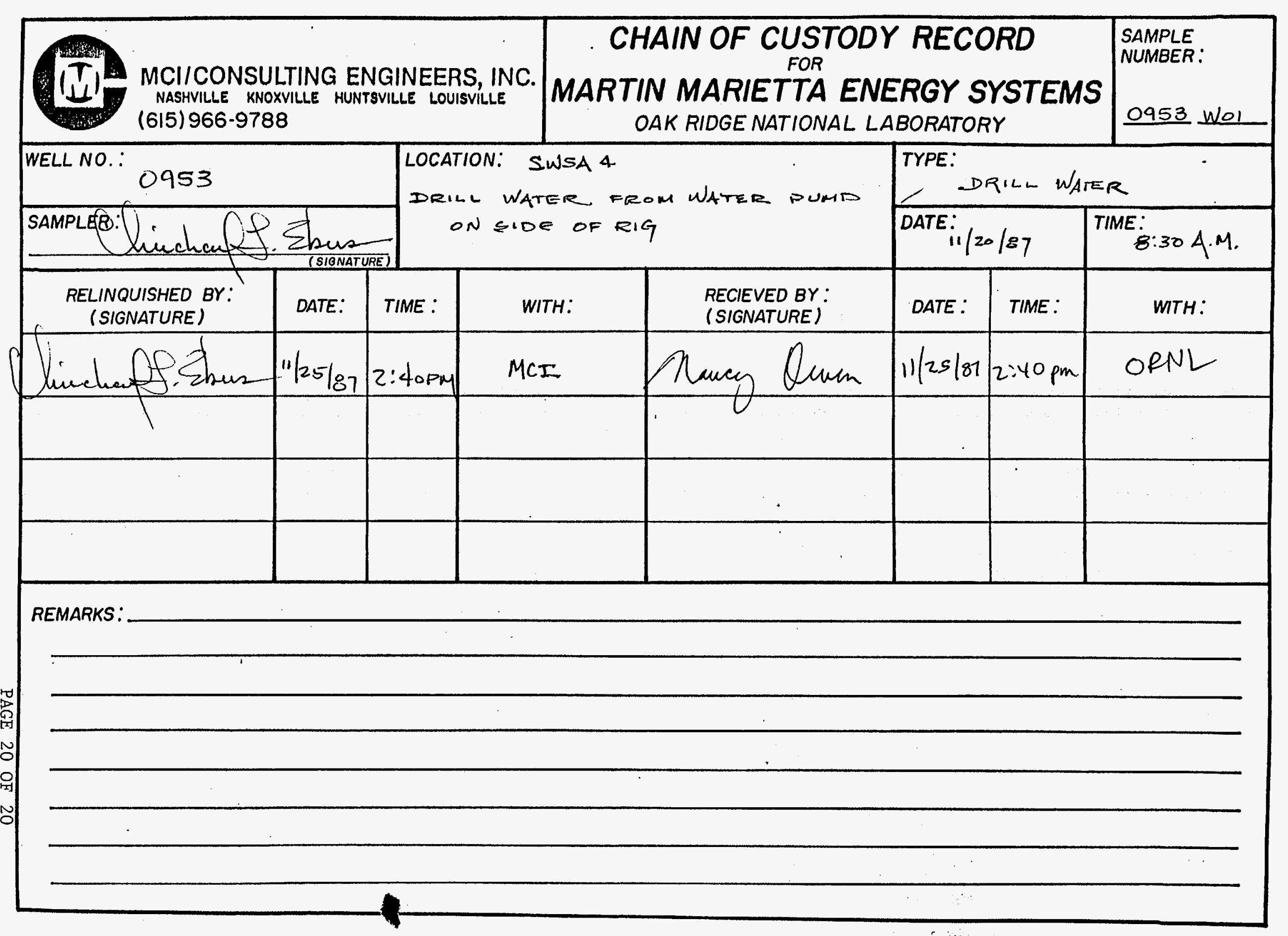




\subsection{General Information}

\subsection{Well Location}

Monitoring well number 954 is located in WAG 4. It is located approximately 650 feet south of the intersection of Melton Valley Drive and Lagoon Road. The location is shown on ORNL drawing number C3E20004A075. Survey coordinates for this well are N 19,252.0613, E 29,252.9303 (X-10 grid) or latitude $35^{\circ}-55^{\prime}-03.18^{\prime \prime}$ and longitude $84^{\circ}-19^{\prime}-00.15^{\prime \prime}$. Coordinate data were provided by Martin Marietta Energy Systems. The method used for conversion from $x-10$ grid to Tennessee-Iambert state Plane coordinates came from the publication "Tennessee Valley Authority Data Services Branch and Mapping Services Branch, Oak Ridge, Tennessee, DOE Plant Control, November 6, 1985, Field Book: EsS-3115, pp. 1-20." The latitude and longitude were calculated by Adams Craft Herz Walker Engineering, Inc., using methods from the U.S. Coast and Geodetic Survey Publication 62-4, "State Plane Coordinates by Automatic Data Processing."

\subsection{Drilling Information}

Well number 954 was drilled by Geotek Engineering Company. An Ingersoll Rand T-4 rig was used to drill this boring for monitor well installation under the operation of Larry Ledbetter with the assistance of Fred Dixon, Tom Doonan and Tracy Mitchell. Drilling commenced on-4/10/90, and was finished on 4/17/90. Paragraph 2.4.1 includes a detailed discussion of the well installation and a well schematic is 
included on the well installation/completion form. A synopsis of the drilling activity follows. This information was typed directly from field notes and was edited only when necessary for clarification.

4/10/90: This location was determined to be Class III. The rig was mobilized to location and set up on 2 sheets of plastic. Split spoon samples were taken from surface to 13.5 feet $(R A D=2 \mathrm{MR} / \mathrm{hr}$. OVA $<0.05 \mathrm{ppm})$. The boring was reamed to 10.0 feet using a 22-inch auger $(R A D=2 M R / h r$. OVA $<0.05 \mathrm{ppm})$. Set 10.0 feet of decontaminated steel diverter casing and grouted it to surface with 9.0 sacks cement.

4/11/90: Drill from 10.0 to 29.5 feet using an 8.0 inch air rotary tricone bit into containment box (RAD = Background, OVA $=4 \mathrm{ppm}$ ). Looked as though the water in hole had an oily sheen on it. OVA was picking up a reading. Set 26.3 feet of 10.0-inch decontaminated steel surface casing with bentonite pellet seal.

4/12/90: Grout surface casing annular with 19.0 sacks cement.

4/16/90: Drill from 26.3 to 62.5 feet using an 8.0 inch air rotary tricone bit into containment box (RAD $\leq$ Background, OVA $=<0.05 \mathrm{ppm}$ ). Hole was bridged at 30.0 feet and needed to be cleaned out.

4/17/90: Clean bridge out and set 4.0 inch stainless steel screen and casing with sandpack and bentonite seal.

4/18/90: Tremie grout annulus with 9.0 sacks cement. During grouting, OVA read 30 to $65 \mathrm{ppm}$. 
Therefore, an Industrial Hygienist was called out to location. The grouting was continued with readings of 20 to $30 \mathrm{ppm}$.

This well was logged by ERC Environmental and Energy Services Co. (ERC) hydrogeologist Timothy A. Lee. All well construction materials and supplies were from Martin Marietta Energy Systems approved batches. The batch origin of individual items is shown on the included Monitoring Well Materials Certification form.

2.0 Technical Information

\subsection{Decontamination Procedures}

The drilling rig, down hole tools, surface casing, stainless steel screen, stainless steel casing, centralizers, and stainless steel silt trap underwent the cleaning decontamination procedures outlined in the drilling specifications (Release specific Technical Directions for Regulatory Compliance Monitoring Wells Phase 1, Oak Ridge National Laboratory, Oak Ridge, W.O. K-4147, April 1987, pgs. 2-4). A checklist of the cleaned materials is included with this data package.

\subsection{Geology}

WAG 4 is located in Melton Valley which is in the Valley and Ridge Physiographic Province of East Tennessee. WAG 4 is underlain by shale, siltstone, and limestone of the Middle to Upper Cambrian Conasauga Group. The Conasauga Group in the Oak Ridge area consists of six formations. They are, in ascending order, the Pumpkin Valley Shale, 
Rutledge Limestone, Rogersville Shale, Maryville Limestone, Nolichucky shale and the Maynardville Limestone. The Pumpkin Valley Shale and Rutledge Limestone underlie WAG 4. Strike in and near WAG 4 ranges from $\mathrm{N} 85^{\circ} \mathrm{E}$ to $\mathrm{N} 15^{\circ} \mathrm{E}$ and dip varies from $27^{\circ}$ to vertical. These variations in strike and dip indicate that the conasauga has been deformed in the locale of WAG 4 .

\section{3 sample collection}

No samples were collected.

\subsection{Installation and Development}

\subsubsection{Installation}

This was a Type B well. A 22.0-inch diameter boring was augered from ground surface to 10.0 feet. A $151 / 4$-inch diverter casing was installed from surface to 10.0 feet below ground surface and grouted in place. The boring was then extended past the diverter casing depth with a 14.0inch air rotary tricone roller bit from 10.0 feet to 26.3 feet. A 10.0-inch diameter string of decontaminated steel surface casing was installed from 0.0 feet to 26.3 feet, sealed with a 2.0-foot bentonite pellet layer from 24.3 feet, and tremie grouted in place. The surface casing minimizes potential cross contamination between the regolith and bedrock water bearing zones. After the surface casing was installed, the air rotary method was used to drill an 8-inch diameter boring to a total depth of 62.5 feet. A 4-inch diameter stainless steel screen with threaded bottom cap was installed from 41.7 feet to 61.9 feet. A 4-inch diameter stainless steel casing was 
installed from the top of the screen at 41.7 feet and extended 3.3 feet above ground surface. A sandpack was then tremied into the annular space from 61.9 feet up to 39.4 feet, with a 1.7-foot bentonite pellet seal poured into the annular space above the sandpack from 37.7 to 39.4 feet. The annular space from the top of the bentonite seal to the surface was tremie grouted with a cement/bentonite slurry. A detailed schematic of the well is included on the well installation/completion form.

\subsubsection{We11 Development}

Well number 954 was developed to remove drill cuttings, silt, and other fines. The monitoring well was developed using a Geoguard pump with an air compressor. All pumps were cleaned prior to use according to specified cleaning procedures (see Paragraph 2.1). The well was developed until a measured total of 825 gallons of water had been evacuated and the clarity of the discharge water was approved by the company representative. The final turbidity value measured at completion was 4.0 NTU's. A development form showing the exact method of development and other pertinent data is appended.

\subsubsection{Installation of Dedicated Monitoring Nell Pump}

After the well was developed, a Geoguard Model No. 5614 dedicated monitoring well pump was installed on 9/17/90 at a depth of 60.6 feet below ground surface. These pumps are decontaminated at American Sigma and are sent prepackaged. A copy of the pump certification is kept on file at ORNL. 


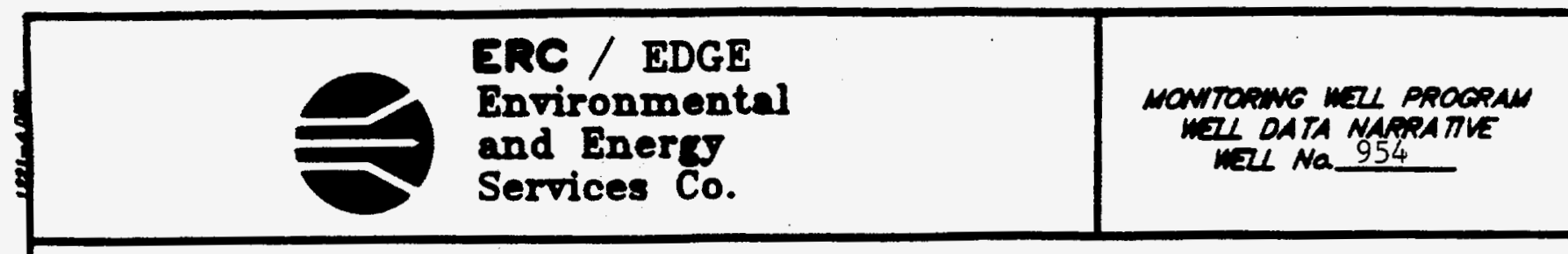

\subsection{Eydraulic conductivity resting}

Well number 954 was tested for the determination of hydraulic conductivity of the aquifer in the vicinity of the well screen. This was accomplished by instantaneously adding a known quantity of water to the monitoring well and measuring the recovery of the water level over time. The changing water levels were measured using a Druck 15 psi pressure transducer and an Omnidata Datapod II data recorder. The hydraulic conductivity value of $1.14 \times 10^{-4}$ $\mathrm{cm} / \mathrm{second}$ (shown as permeability on the hydraulic conductivity calculations printout attached) was calculated using the Bouwer and Rice method. A computer printout of the hydraulic conductivity calculations is included in this data package. 
ERC / EDGE

Environmental

and Enerey

WEZL NO. 954

\section{PRE-DRILLING CHECKLIST FOR MONITORING WELLS}

PRE-DRILUNG TASKS

1. EXCAVTION PERMIT OBTAINED

2. ALL EQUIPMENT HAS BEEN CLEANED BEFORE DRILLING.

30. SCREEN AND CASING HAVE BEEN WASHED, STEAMED, RINSED WTH DE-IONIZED OR DISTLLED WATER, RINSED WTH ISOPROP N ALCOHOL, WRAPPED WIH PROTECTVE COVERING AND STORED OFF THE GROUND.

36. PRE-PACKAGED SCREENS, CASING AND CENTRALIZERS WERE USED.

4. WORK AREA FOR SAMPLE EXAMINATION COVERED WTH CLEAN POLYETHYENE.

5. CLEAN KNIVES, GLOVES, SAMPLE JARS AND LABELS ON HAND.

6. POLYETHRENE COVER IN PLACE OVER HOLE.

7. AIR ROTARY COMPRESSED AIR SAMPLED.

COMPLIANCE

$\frac{\frac{\text { DATE }}{4 / 10 / 90}}{\frac{\text { INIRALS }}{\text { 4/10/90 }}} \frac{\text { T/A }}{\text { N/A }}$

$4 / 17 / 90$

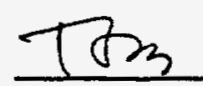

$4 / 10 / 90$

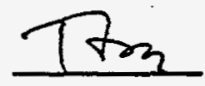

$4 / 10 / 90$

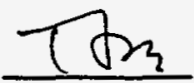

$4 / 10 / 90$

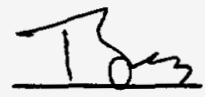

$4 / 16 / 90$

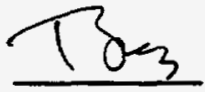

RESULTS: No detectable hydrocarbons under ultraviolet light

ADOITONAL NOTES/OBSERVA TONS:

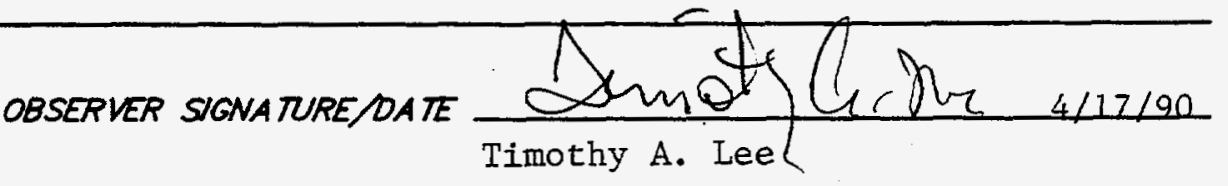

PAGE 7 of 20. 


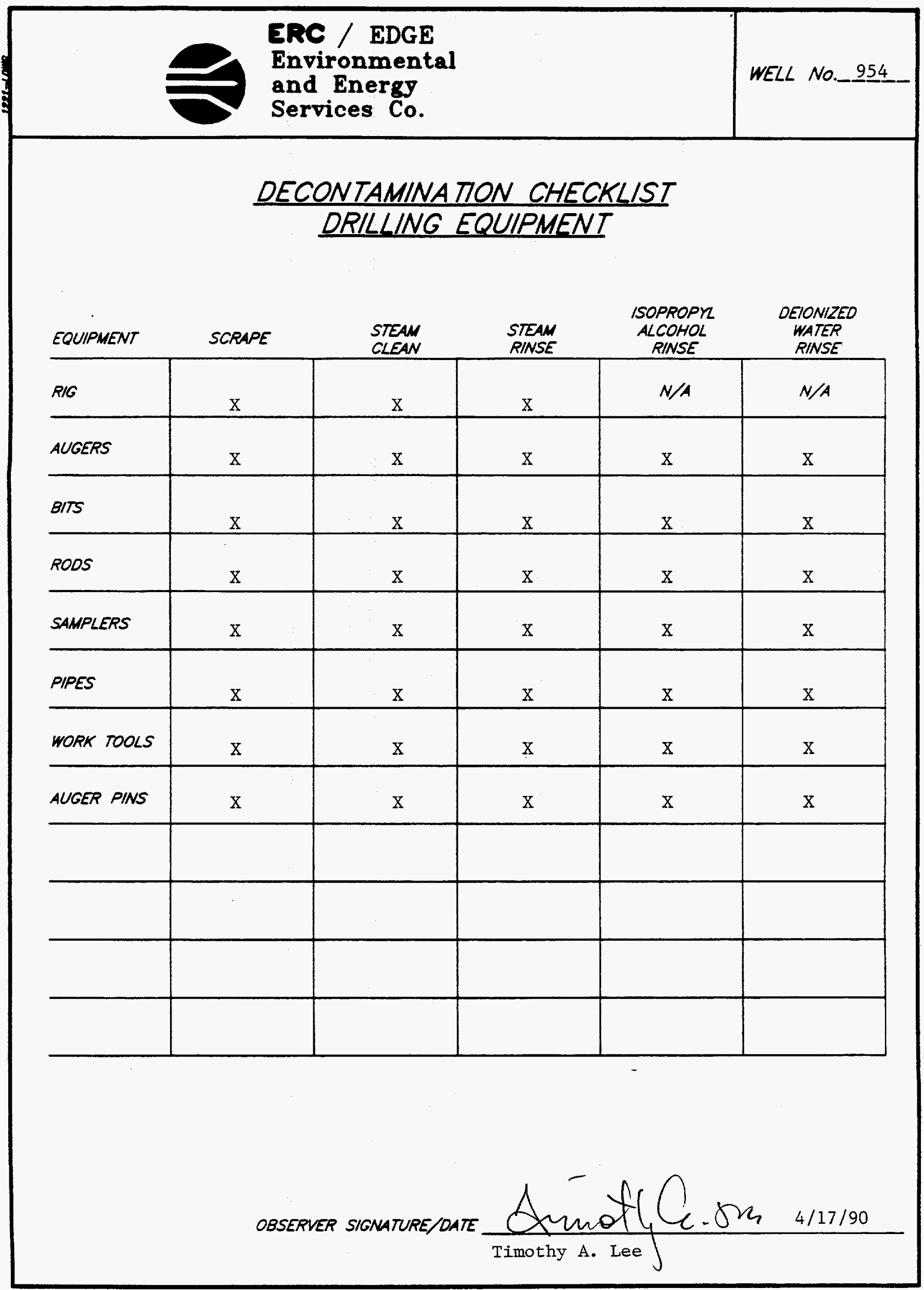

PAGE 8 OF 20. 


\begin{tabular}{|c|c|c|c|c|}
\hline & & & $\begin{array}{l}\text { SRe / E } \\
\text { Environm } \\
\text { and Ener } \\
\text { Services }\end{array}$ & $\begin{array}{l}\text { GE } \\
\text { ental } \\
\text { D } \\
\text { o. }\end{array}$ \\
\hline & ORNL & MONITORIN & WELL LOG & PAGE 1 OF 2 \\
\hline & Xa nON. & WAG4 & & DATE: START: $4 / 10 / 90$ \\
\hline & PLLER: & Larry Led & etter & FINISH: $4 / 17 / 90$ \\
\hline & & & Tom Doonan, & LOGGED BY: Timothy A. Lee \\
\hline & $\begin{array}{l}\text { LPER: } \\
\text { RLL: }\end{array}$ & Ingersol1 & and $\mathrm{T}-4$ & HEALTH PHYSHCIST: C.E. Stooksbury \\
\hline & PE DRK & UNW: Split & poon, auger, & air rotary LUBRICANT TMPE:_ Green stuff \\
\hline & D. SAMP & LES TAKEN:- & None & MPE: \\
\hline & SNTAIN & IENT TMPE: & stic, pan, & ontainment box \\
\hline & HCKNES: & $S$ of SOL KRE & USAL DEPTH): & DRILLNG FLUID SAMPLES: \\
\hline & $P T H D$ & WLED IN ROCX & & MPE: N/A DATE:_N/A \\
\hline & DTAL OE & PTH of WEZL: & . & $62.5^{\prime}$ \\
\hline $\begin{array}{l}D E F \\
\text { (FE }\end{array}$ & & $\begin{array}{l}\text { SAMPLE } \\
\text { (NUMBER \& }\end{array}$ & $\begin{array}{c}\text { PERCENT } \\
\text { RECOVERY }\end{array}$ & SOL/BEDROCK DESCRIPIION \\
\hline FROW & 70 & (NTERVAL) & (SPLUT SPOONS) & \\
\hline 0.0 & 5.0 & & Augered & Gravel fill \\
\hline 5.0 & 6.0 & & Augered & $\mathrm{RAD}=1 \mathrm{MR} / \mathrm{hr}$ \\
\hline 6.0 & 8.0 & & $5 \%$ & Clay, mottled dark yellowish brown and grayish \\
\hline & & & & brown, slightly silty, moist $\mathrm{RAD}=.5 \mathrm{MR} / \mathrm{hr}$ \\
\hline 8.0 & 10.0 & & $50 \%$ & $\mathrm{RAD}=2 \mathrm{MR} / \mathrm{hr} ;$ clay, mottled dark yellowish \\
\hline & & & & orange and pale olive, iron stains, scarlet \\
\hline & & & & specs; dripping wet; scattered leaves and \\
\hline & & & & vegetation \\
\hline 10.0 & 12.0 & & $50 \%$ & Clay, silty, mottled dark yellowish orange to \\
\hline & & & & light olive gray, dripping wet, black specs \\
\hline & & & & and reddish brown specs, iron stains. $\mathrm{RAD}$ \\
\hline & & & & $=$ Background \\
\hline 12.0 & 13.0 & & $50 \%$ & Shale, iron stains, light olive gray, dripping \\
\hline & & & & wet \\
\hline 13.0 & 13.5 & & $50 \%$ & Shale, medium bluish gray, crumbly \\
\hline & 13.5 & & & Split spoon refusal \\
\hline & 13.5 & & & Auger refusal \\
\hline 13.5 & 14.0 & & Air Rotary & *Shale, softer \\
\hline 14.0 & 15.5 & & & *Limestone, hard \\
\hline 15.5 & 16.0 & & & *Shale, softer \\
\hline
\end{tabular}




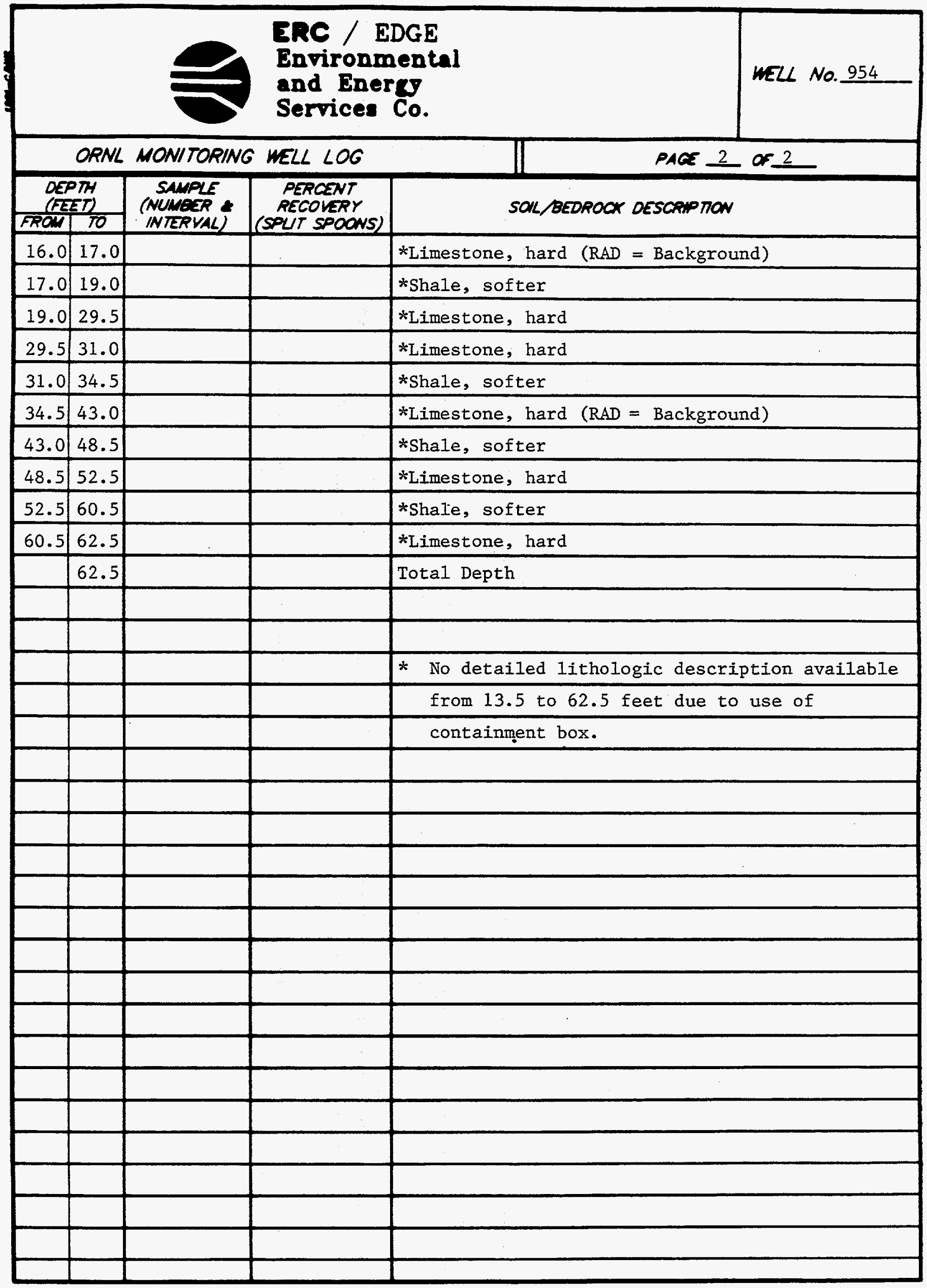




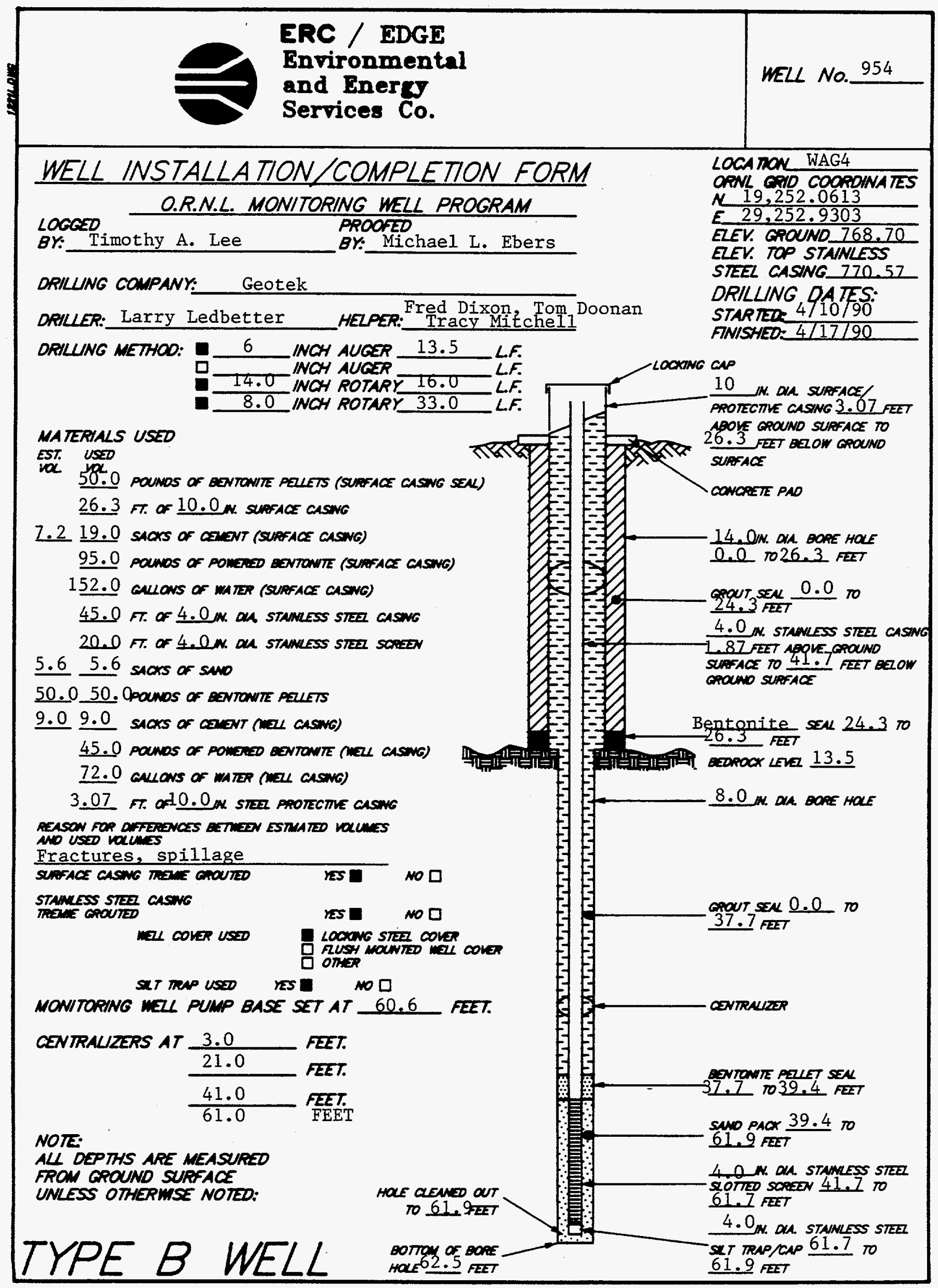

PACE 11 of 20 
ERC / EDGE

Environmental

WELL NO. 954

and Energy

Services Co.

OATE: $4 / 18 / 90$

\section{MONITORING WELL MATERIALS CERTIFICATION}

ITEM/MA TERIAL

\begin{tabular}{|c|c|c|}
\hline & DATE USED & BATCH NUMBER \\
\hline & $1 / 17100$ & 0 \\
\hline \multirow{2}{*}{ Powder } & $4 / 18 / 90$ & 6 \\
\hline & $4 / 17 / 90$ & 1 \\
\hline \multirow{2}{*}{ 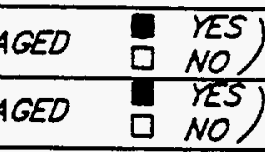 } & $4 / 17 / 90$ & 3 \\
\hline & $4 / 17 / 90$ & 3 \\
\hline$\left(\begin{array}{ll}\text { GES } \\
\text { NO }\end{array}\right)$ & $4 / 17 / 90$ & 3 \\
\hline \multirow{2}{*}{ 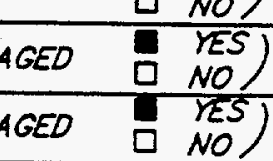 } & $4 / 17 / 90$ & 3 \\
\hline & $9 / 17 / 90$ & 8 \\
\hline \multirow{2}{*}{$\begin{array}{l}\text { rface casing } \\
11 \text { casing }\end{array}$} & $4 / 12 / 90$ & 7 \\
\hline & $4 / 18 / 90$ & 7 \\
\hline \multicolumn{2}{|r|}{$4 / 11 / 90$} & 4 \\
\hline
\end{tabular}

BENTONITE

(PREPACKAGED

(PREPACKAGED

STAINLESS STEEL CASING

(PREPACKAGED

STAINLESS STEEL CENTRALIZERS

STAINLESS STEEL CAPS

MONITORING WELL PUMP

(PREPACKAGED

(PREPACKAGED

GROUT

surface casing

well casing

WELL COVERS

SURFACE CASING

$4 / 11 / 90$

COMMENTS:

OBSERVER SIGNATURE DATE Shunthle he 4/18/90 


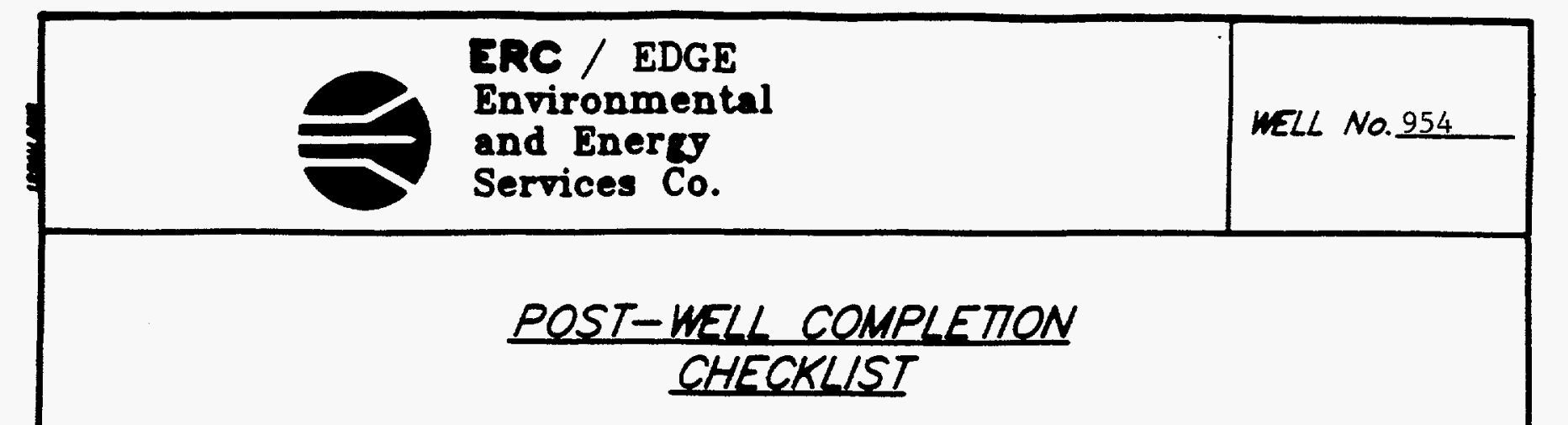

\section{POST-WELL COMPLETION TASKS}

1. WU SCRAPED FRON AUESRS SMMPLERS ANO ALL OTHER EQUIPWENT.

2. ALL WUO FROM RIG AND EOUIPNENT SCRAPWGS ANO CUTINOS OASPOSED OF IN ACCOROANCE WIH THE SPECFTCA IION * PROWOED.

3 MEL OEVZZOAED IN ACCOPOANCE WTH THE SPECHCA ION" PROVOED AND DETAKS OF THE OEVZLOMENT ACTUT RECOROED.

4. ORWLNG STE PROPERLY CLEANED UP AFTER COMPLENION of WZL INSTALUIION.

$$
\begin{aligned}
& \text { COMPLIANCE } \\
& \text { DA.E INITALS }
\end{aligned}
$$

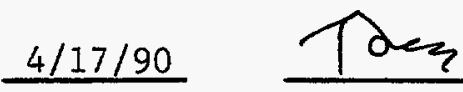

$4 / 17 / 90+1723$

$9 / 17 / 90$

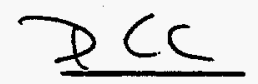

$4 / 17 / 90$

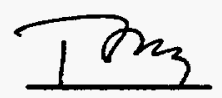

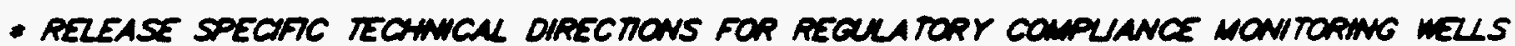
PHASE 1. OAK RHOCE NATIONAL LABORATORY, OAK RIDGE W. K-4147, APRK 1997.

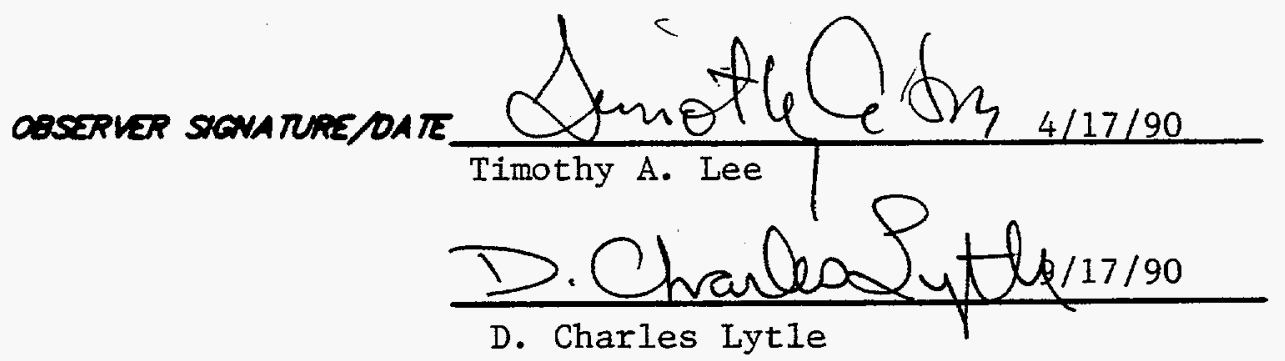

D. Charles Lytle 
ERCE

Environmental

and Energy

Services Co.

\section{MONITORING WELL DEVELOPMENT FORM}

DEVELOPMENT DETAILS

METHOD OF

DEVELOPMENT: Pumping with Geoguard pump

DEVELOPMENT

BEGAN DATE: $\quad 8 / 13 / 90$

TME:

DEVELOPMENT

ENDING DATE:

$9 / 17 / 90$

OEVELOPMENT

OBSERVED BY:

D. Charles Lytle

ONE WELL VOLUME: 54.6 GALLONS

TOTAL GALLONS PUMPED:_ 825 TOTAL WELL VOLUMES PUMPED: 15.1

INITAL PH:11.0 FNAL PH: $9: 3$

INITAL CONDUCTUTY ( $\mathrm{HS} / \mathrm{cm}):-935 \quad$ FNAL CONDUCTUTY $(\mu \mathrm{s} / \mathrm{cm}): 090$

DESCRIPTION OF INITAL RURBIDITY: Cloudy

DESCRIPTION OF FINAL TURBIOITY:_Clear

FNAL MEASURED TURBIDITY: $4.0 \mathrm{NTU}^{\prime} \mathrm{S}$

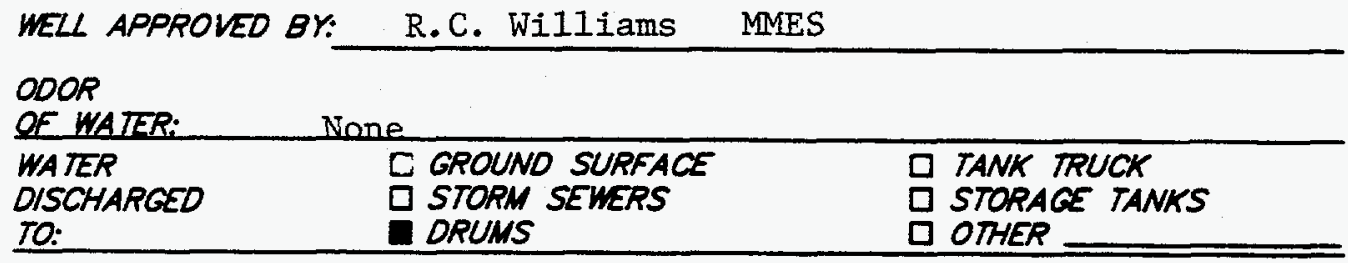

INITAL PRE-DEVELOPMENT

WATER DEPTH: 2.3 feet from ground surface

DEVELOPMENT OBSERVATIONS

OVA tests read anywhere from 100 to $1000 \mathrm{ppm}$ coming from well and barrels,

breathing zone was fine. 


\section{ERC / EDGE \\ Environmental \\ and Energy \\ Services Co.}

mZL NO. $\frac{954}{\text { Lower }}$

LOCA TON: WAG

DATE: $8 / 13 / 90$

\section{MONITORING WELL DEVELOPMENT PROGRESS}

Page 1 of 2

ONE MEL VOCUME $=54.6$

GALLONS

\begin{tabular}{|c|c|c|c|c|c|c|c|c|c|}
\hline$D A T E$ & TIME & $\begin{array}{l}\text { GNLONS } \\
\text { PUMPED }\end{array}$ & $\begin{array}{c}\text { Descompiow } \\
\text { of } \\
\text { ruaurr }\end{array}$ & 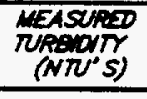 & $p H$ & $\begin{array}{c}\text { conouc- } \\
\text { murr } \\
\text { (us) }\end{array}$ & $\begin{array}{l}\text { TOTAN } \\
\text { GNuaws } \\
\text { Punfed }\end{array}$ & $\begin{array}{l}\text { Mazi } \\
\text { valumes } \\
\text { PunPED }\end{array}$ & COMMENTS \\
\hline $8 / 13 / 90$ & 1100 & 22 & Cloudy & -- & 11.0 & 935 & 22 & & \\
\hline $8 / 13 / 90$ & 1300 & 10 & Cloudy & -- & 10.7 & 964 & 32 & & \\
\hline $8 / 16 / 90$ & 1300 & 55 & Cloudy & -- & 11.0 & 025 & 87 & 1.6 & \\
\hline $8 / 17 / 90$ & 0800 & 78 & Cloudy & -- & 12.7 & 369 & 165 & 3.0 & \\
\hline $8 / 17 / 90$ & 1100 & 55 & Cloudy & - & 10.0 & 039 & 220 & 4.0 & \\
\hline $8 / 17 / 90$ & 1430 & 48 & Cloudy & -- & 9.9 & 061 & 268 & 4.9 & \\
\hline $8 / 20 / 90$ & 0800 & 17 & Cloudy & --- & 9.9 & 062 & 285 & 5.2 & \\
\hline $8 / 27 / 90$ & 1330 & 53 & Cloudy & --- & 11.9 & 264 & 338 & 6.2 & \\
\hline $8 / 28 / 90$ & 0830 & 10 & Milky & -- & 10.7 & 086 & 348 & 6.3 & \\
\hline $8 / 28 / 90$ & 1430 & 20 & Milky & -- & 11.1 & 201 & 368 & 6.7 & \\
\hline $8 / 29 / 90$ & 0900 & 5 & Milky & -- & 10.3 & 075 & 373 & 6.8 & \\
\hline $8 / 29 / 90$ & 1100 & 10 & Milky & -- & 10.4 & 097 & 383 & 7.0 & \\
\hline $8 / 30 / 90$ & 0800 & 5 & Milky & -- & 10.2 & 065 & 388 & 7.1 & \\
\hline $8 / 30 / 90$ & 1400 & 20 & Milky & -- & $10 . d$ & 140 & 408 & 7.5 & \\
\hline $8 / 31 / 90$ & 0800 & 5 & Millky & $=$ & 10.4 & 057 & 413 & 7.5 & \\
\hline $8 / 31 / 90$ & 1430 & 20 & Milky & --- & 9.9 & 066 & 433 & 7.9 & \\
\hline $9 / 4 / 90$ & 0900 & 5 & Milky & -- & 9.9 & 067 & 438 & 8.0 & \\
\hline $\begin{array}{l}\text { RESULTS } \\
\text { OF DEVE }\end{array}$ & $\begin{array}{l}\text { ENO } \\
\text { ENT }\end{array}$ & & & & & & & & \\
\hline
\end{tabular}

COMMENTS 


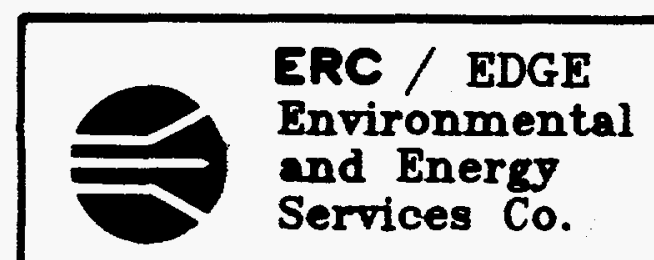

\section{MONITORING WELL DEVELOPMENT PROGRESS}

WEL NO. $\frac{954}{\text { LOWEY }}$
LOCA HON: WAC4
DATE: $8 / 13 / 90$

\begin{tabular}{|c|c|c|c|c|c|c|c|c|c|}
\hline & & & & & & & $\begin{array}{l}\text { ge } 2 \\
\text { weZ }\end{array}$ & IME $=$ & 6 GALLONS \\
\hline$D A T E$ & TIME & $\begin{array}{l}\text { ancons } \\
\text { Pumped }\end{array}$ & $\begin{array}{c}\text { DEsSOEPTOW } \\
\text { of } \\
\pi \text { mevorr }\end{array}$ & 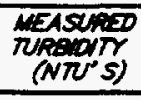 & $\rho H$ & 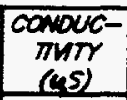 & $\begin{array}{l}\text { TotNk } \\
\text { gnllaws } \\
\text { Punped }\end{array}$ & $\begin{array}{l}\text { WEII } \\
\text { WOLUMES } \\
\text { PUMPED }\end{array}$ & COMMENTS \\
\hline $9 / 4 / 90$ & 1430 & 45 & Cloudy & -- & 9.5 & 162 & 483 & 8.8 & \\
\hline $9 / 5 / 90$ & 0800 & 5 & Muddy & --- & 10.6 & 093 & 488 & 8.9 & \\
\hline $9 / 5 / 90$ & 1400 & 15 & Cloudy & -- & 9.9 & 055 & 503 & 9.2 & \\
\hline $9 / 6 / 90$ & 0900 & 5 & Cloudy & -- & 9.9 & 081 & 508 & 9.3 & \\
\hline $9 / 6 / 90$ & 1430 & 45 & Cloudy & -- & 9.5 & 140 & 553 & 10.1 & \\
\hline $9 / 12 / 90$ & 0900 & 107 & Cloudy & - & 9.8 & 056 & 660 & 12.1 & \\
\hline $9 / 12 / 90$ & 1430 & 30 & Cloudy & -- & 9.7 & 047 & 690 & 12.6 & \\
\hline $9 / 13 / 90$ & 0800 & 20 & Cloudy & -- & 9.7 & 062 & 710 & 13.0 & \\
\hline $9 / 13 / 90$ & 1000 & 15 & Cloudy & -- & 9.6 & 089 & 725 & 13.3 & \\
\hline $9 / 14 / 90$ & 1100 & 75 & Cloudy & -- & -- & -- & 800 & 14.7 & \\
\hline $9 / 17 / 90$ & 1400 & 25 & Clear & 4.0 & 9.3 & 090 & 825 & 15.1 & \\
\hline & & & & & & & & & \\
\hline & & & & & & & & & \\
\hline & & & & & & & & & \\
\hline & & & & & & & & & \\
\hline & & & & & & & & & \\
\hline $\begin{array}{l}\text { RESULTS } \\
\text { OF DEVE }\end{array}$ & TENO & & Clear & 4.0 & 9.3 & 090 & 825 & 15.1 & \\
\hline
\end{tabular}

COMMENTS

Excellent recharger and producer. Water finally cleared.and passed

with $4.0 \mathrm{NTU}^{\prime} \mathrm{s}$. 


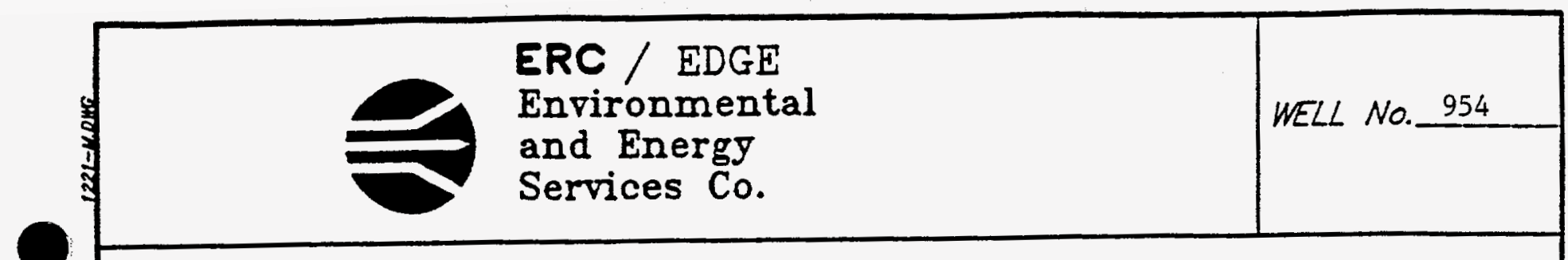

\title{
HYDRAULIC CONDUCTIVTY CALCULATIONS
}

PROGRAM SLUGT, VERSION 4.1, NOV. 1986

THIS PROGRAM CALCULATES MEAN TRANSMISSIVITIES FROM

SLUG-TEST DATA BASED ON TWO ANALYTICAI APPROACHES:

(1) METHOD OF COOPER, BREDEHOEFT AND PAPADOPULOS, 1967

(ARTICLE IN VOL.3, NO. 1 OF WRR ENTITLED

"RESPONSE OF A FINITE DIAMETER WELI TO AN INSTANTANEOUS CHARGE OF WATER")

(2) METHOD OF BOUWER AND RICE, 1976 (ARTICIE IN

VOI. 12, NO.3 OF WRR ENTITLED

"A SIUG TEST FOR DETERMINING HYDRAULIC CONDUCTIVITY

OF UNCONFINED AQUIFERS WITH COMPLETELY OR PARTIALLY PENETRATING WELLS")

WELI NO.: 954

DATE OF TEST: $10-30-90$

PROJECT NO.: E221-002

CLIENT : MMES

SITE LOCATION: WAG-4

EDGE, INC. FIELD INVESTIGATOR: JAMES W. CARUTHERS

\section{INPUT DATA ARE:}

INNER CASING DIAMETER $=4.00$ INCHES

INNER SCREEN OR OPEN-HOLE DIAMETER $=4.00$ INCHES

DIAMETER OF DRILIED HOLE $=8.00$ INCHES

LENGTH OF SCREEN OR INTAKE PORTION $=20.00$ FEET

DEPTH FROM STATIC LEVEL TO BOTTOM OF SCREEN $=59.80$ FEET

THICKNESS OF SATURATED AQUIFER ZONE $=20.00$ FEET

DEPTH TO STATIC WATER LEVEL BELOW REF. POINT $=1.00$ FEET

ESTIMATED POROSITY OF GRAVEL PACK $=.20$

FALLING-HEAD INDEX $=1$ ("I" IF FALIING,"O" IF RISING)

NUMBER OF DEPTH-TIME DATA POINTS = 32

HO WAS COMPUTED FROM INTERCEPT OF PLOT OF LOG(H) VS. TIME

\author{
SUCCESSIVE COMPUTED \\ VALUES FOR HO \\ (FEET) \\ 4.4044 \\ 4.4074
}




\begin{tabular}{|c|c|c|}
\hline$\left(\mathrm{SEC}^{\text {TIME }}\right)$ & $\begin{array}{l}\text { DEPTH TO WATER } \\
\text { (FEET) }\end{array}$ & $\begin{array}{l}\text { HEAD } \\
\text { (FEET) }\end{array}$ \\
\hline $\begin{array}{r}10.00 \\
20.00 \\
30.00 \\
40.00 \\
50.00 \\
60.00 \\
75.00 \\
90.00 \\
105.00 \\
120.00 \\
150.00 \\
180.00 \\
240.00 \\
300.00 \\
360.00 \\
420.00 \\
480.00\end{array}$ & $\begin{array}{l}5.430 \\
5.430 \\
5.430 \\
5.430 \\
5.410 \\
5.400 \\
5.360 \\
5.360 \\
5.340 \\
5.320 \\
5.300 \\
5.290 \\
5.240 \\
5.230 \\
5.180 \\
5.140 \\
5.100\end{array}$ & $\begin{array}{l}4.430 \\
4.430 \\
4.430 \\
4.430 \\
4.410 \\
4.400 \\
4.360 \\
4.360 \\
4.340 \\
4.320 \\
4.300 \\
4.290 \\
4.240 \\
4.230 \\
4.180 \\
4.140 \\
4.100\end{array}$ \\
\hline $\begin{array}{r}540.00 \\
600.00 \\
720.00 \\
840.00 \\
960.00 \\
1080.00 \\
1200.00 \\
1320.00 \\
1440.00 \\
1560.00 \\
1680.00 \\
1800.00 \\
1920.00 \\
2040.00 \\
2160.00\end{array}$ & $\begin{array}{l}5.070 \\
5.010 \\
4.930 \\
4.900 \\
4.810 \\
4.750 \\
4.700 \\
4.670 \\
4.590 \\
4.560 \\
4.480 \\
4.430 \\
4.390 \\
4.340 \\
4.310\end{array}$ & $\begin{array}{l}4.070 \\
4.010 \\
3.930 \\
3.900 \\
3.810 \\
3.750 \\
3.700 \\
3.670 \\
3.590 \\
3.560 \\
3.480 \\
3.430 \\
3.390 \\
3.340 \\
3.310\end{array}$ \\
\hline
\end{tabular}




\title{
HYDRAULIC CONDUCTIVTY CALCULATIONS
}

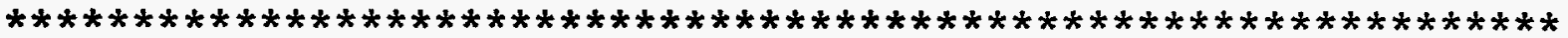 \\ METHOD OF BOUWER AND RICE \\ COMPUTED RESULTS USING DIAMETER OF DRILLED HOLE: \\ PERMEABILITY $=3.73 \mathrm{E}-07 \mathrm{FT} / \mathrm{SEC}=1.14 \mathrm{E}-05 \mathrm{CM} / \mathrm{SEC}$ \\ TRANSMISSIVITY $=7.47 \mathrm{E}-06 \mathrm{FT} * * 2 / \mathrm{SEC}$
}

COMPUTED RESULTS USING DIAMETER OF CASING AND SCREEN:

PERMEABILITY $=4.31 \mathrm{E}-07 \mathrm{FT} / \mathrm{SEC}=1.32 \mathrm{E}-05 \mathrm{CM} / \mathrm{SEC}$

TRANSMISSIVITY $=8.63 \mathrm{E}-06 \mathrm{FT} * * 2 / \mathrm{SEC}$ 
ERC / EDGE

Environmental

and Energy

WELL NO. 954

\section{HYORAULIC CONDUCTIVTY CALCULATIONS}

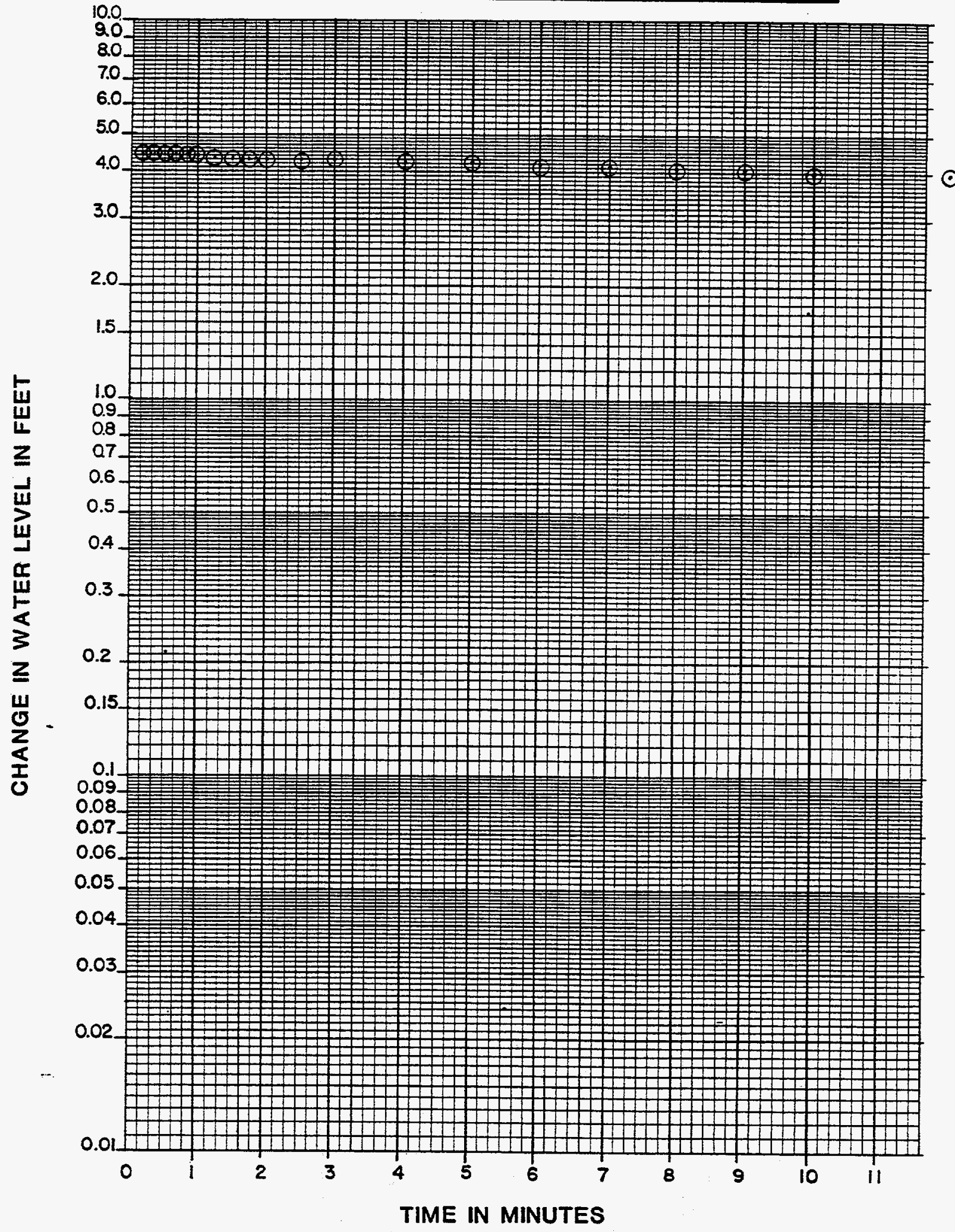

PACE 20 of 20 


\subsection{General Information}

\subsection{We11 Iocation}

Monitoring well number 955 is located in WAG 4. It is located approximately 650 feet southwest from the intersection of Melton Valley Drive and Lagoon Road. The location is shown on ORNL drawing number C3E20004A075. Survey coordinates for this well are $N$ 19,243.5391, E $29,239.1533\left(x-10\right.$ grid) or latitude $35^{*}-55^{1}-03.03^{\prime \prime}$ and longitude $84^{\circ}-19^{\prime}-00.23^{\prime \prime}$. Coordinate data were provided by Martin Marietta Energy Systems. The method used for conversion from X-10 grid to Tennessee-Lambert state Plane coordinates came from the publication "Tennessee valley Authority Data Services Branch and Mapping Services Branch, Oak Ridge, Tennessee, DOE Plant Control, November 6, 1985 , Field Book: Ess-3115, pp. 1-20." The latitude and longitude were calculated by Adams Craft Herz Walker Engineering, Inc., using methods from the U.S. Coast and Geodetic Survey Publication 62-4, "State Plane Coordinates by Automatic Data Processing."

\subsection{Drilling Information}

Well number 955 was drilled by Geotek Engineering Company . An Ingersoll Rand T-4 rig was used to drill this boring for monitor well installation under the operation of Iarry Ledbetter with the assistance of Fred Dixon, Tom Doonan and Tracy Mitchell. Drilling commenced on 4/12/90 and was finished on 4/17/90. Paragraph 2.4.1 includes a detailed discussion of the well installation and a well schematic is included on the well installation/completion form. A synopsis of the drilling activity follows. This 
information was typed directly from field notes and was edited only when necessary for clarification.

4/12/90: This location was determined to be class III. The rig was moved to location and set up as 2 sheets of plastic. Augered from surface to 9.5 feet using a 14.0 inch auger. ( $R A D=10,000$ cpm, OVA $=<0.05 \mathrm{ppm})$. Set 10.0 feet of 10 inch decontaminated steel diverter casing with 50.0 lbs bentonite pellets and grouted it to surface with 5.0 sacks cement.

4/17/90: Drill from 9.5 to 22.5 feet using an 8.0 inch air rotary tricone bit into a containment box (RAD $\leq$ Background, OVA $=<0.05 \mathrm{ppm}$ ). Set 2 inch stainless steel well screen and casing with sandpack and bentonite seal.

4/18/90: Grout annulus with 3.5 sacks cement. (OVA $=1$ Ppm, RAD $\leq$ Background)

This well was logged by ERC Environmental and Energy Services Co. (ERC) hydrogeologist Timothy A. Lee. All well construction materials and supplies were from Martin Marietta Energy Systems approved batches. The batch origin of Individual items is shown on the included Monitoring Well Materials Certification form.

2.0 Technical Information

\subsection{Decontamination Procedures}

The drilling rig, down hole tools, surface casing, stainless steel screen, stainless steel casing, centralizers, and stainless steel silt trap underwent the 
cleaning decontamination procedures outlined in the drilling specifications (Release specific Technical Directions for Regulatory Compliance Monitoring Wells Phase 1, Oak Ridge National Laboratory, Oak Ridge, w.O. K-4147, April 1987, pgs. 2-4). A checklist of the cleaned materials is included with this data package.

\subsection{Geology}

WAG 4 is located in Melton valley which is in the valley and Ridge Physiographic Province of East Tennessee. WAG 4 is underlain by shale, siltstone, and limestone of the Middle to Upper Cambrian Conasauga Group. The Conasauga Group in the Oak Ridge area consists of six formations. They are, in ascending order, the Pumpkin Valley Shale, Rutledge Limestone, Rogersville Shale, Maryville Limestone, Nolichucky Shale and the Maynardville Limestone. The Pumpkin Valley Shale and Rutledge Limestone underlie WAG 4. strike in and near WAG 4 ranges from N $85^{\circ} \mathrm{E}$ to $\mathrm{N} 15^{\circ} \mathrm{E}$ and dip varies from $27^{\circ}$ to vertical. These variations in strike and dip -indicate that the conasauga has been deformed in the locale of WAG 4.

\section{3 sample collection}

No samples were collected. 


\subsection{Installation and Development}

\subsubsection{Installation}

This was a Type D well. The air rotary method was required to complete the boring to the specified total well depth. Therefore, a 14.0-inch diameter boring was augered from ground surface to 9.5 feet and a 10.0-inch diverter casing was installed and grouted. An 8-inch diameter boring was then drilled with an air rotary tricone roller bit from 9.5 to 22.5 feet. A 2-inch diameter stainless steel screen with threaded bottom cap was installed from 12.2 to 22.4 feet. A 2-inch diameter stainless steel casing was installed above the screen at 12.2 feet and extended 2.8 feet above ground surface. A sandpack was then tremied into the annular space from 22.4 feet up to 10.8 feet, with a 1.7-foot bentonite pellet seal poured into the annular space above the sandpack from 9.1 to 10.8 feet. The annular space from the top of the bentonite seal to the surface was tremied-grouted with a cement/bentonite slurry. A detail of the well is included on the well installation/ completion form.

\subsubsection{We11 Development}

Well number 955 was developed to remove drill cuttings, silt, and other fines. The monitoring well was developed using a Geoguard pump with an air compressor. All pumps were cleaned prior to use according to specified cleaning procedures (see Paragraph 2.1). The well was developed until a measured total of 220 gallons of water had been evacuated and the clarity of the discharge water was approved by the company representative. The final 


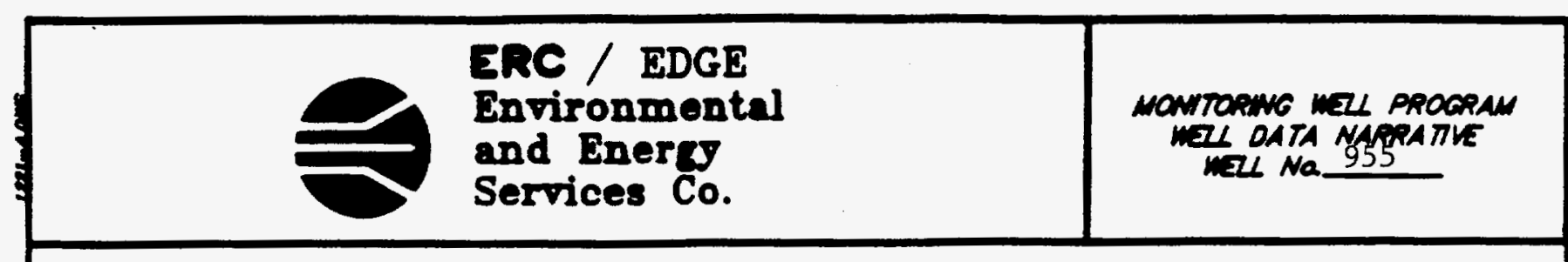

turbidity value measured at completion was 4.0 NTU's. A development form showing the exact method of development and other pertinent data is appended.

\subsubsection{Installation of Dedicated Monitoring Well Pump}

After the well was developed, a Geoguard Model No. 5614 dedicated monitoring well pump was installed on $8 / 16 / 90$ at a depth of 20.8 feet below ground surface. These pumps are decontaminated at American Sigma and are sent prepackaged. A copy of the pump certification is kept on file at ORNL.

\subsection{Hydraulic Conductivity Testing}

Well number 955 was tested for the determination of hydraulic conductivity of the aquifer in the vicinity of the well screen. This was accomplished by instantaneously adding a known quantity of water to the monitoring well and measuring the recovery of the water level over time. The changing water levels were measured using a Druck 15 psi pressure transducer and an Omnidata Datapod II data recorder. The hydraulic conductivity value of $2.42 \times 10^{-4}$ $\mathrm{cm} / \mathrm{second}$ (shown as permeability on the hydraulic conductivity calculations printout attached) was calculated using the Bouwer and Rice method. A computer printout of the hydraulic conductivity calculations is included in this data package. 
ERC / EDGE

Environmental

and Enerey

WELL No. .955

\section{PRE-DRILLING CHECKLIST FOR MONITORING WELLS}

\section{RRE-DRILUNG TASKS}

1. EXCAVTION PERMIT OBTAINED

2. ALL EQUIPMENT HAS BEEN CLEANED BEFORE DRIUUNG.

3a. SCREEN AND CASING HAVE BEEN WASHED, STEAMED, RINSED WTH OE-IONIZED OR DISTLLED WATER, RINSED WTH ISOPROPY ALCOHOL, WRAPPED WTH PROTECTVE COVERING AND STORED OFF THE GROUND.

3b. PRE-PACKAGED SCREENS, CASING AND CENTRALIZERS WERE USED.

4. WORK AREA FOR SAMPLE EXAMINATION COVERED WTH CLEAN POL KETHRENE.

5. CLEAN KNIVES, GLOVES, SAMPLE JARS AND LABELS ON HAND.

6. POLYETHRENE COVER IN PLACE OVER HOLE.

7. AIR ROTARY COMPRESSED AIR SAMPLED.
COMPLANCE

\begin{tabular}{|c|c|}
\hline \multicolumn{2}{|c|}{ COMPLANCE } \\
\hline DAIE & $\angle N \mid M A L S$ \\
\hline $4 / 12 / 90$ & $\sqrt{3}$ \\
\hline $4 / 12 / 90$ & $\sqrt{182}$ \\
\hline $\mathrm{N} / \mathrm{A}$ & $\mathrm{N} / \mathrm{A}$ \\
\hline
\end{tabular}

$4 / 17 / 90$

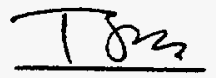

$4 / 12 / 90$

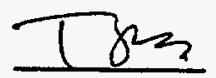

$4 / 12 / 90$

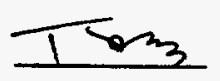

$4 / 17 / 90$

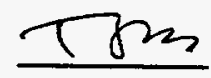

$4 / 17 / 90$

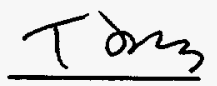

RESULTS: No detectable signs of hydrocarbons under ultraviolet light.

ADOITONAL NOTES/OBSERVATONS:

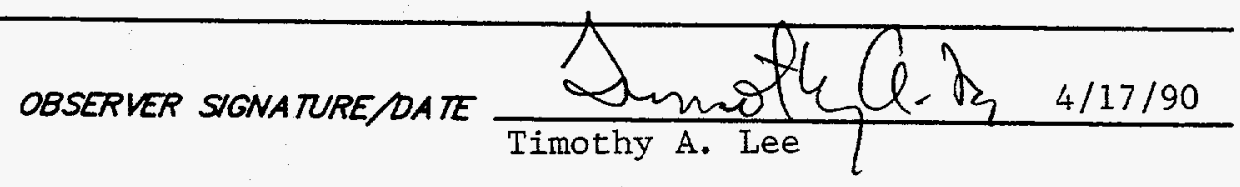

PAGE 6 of 16 


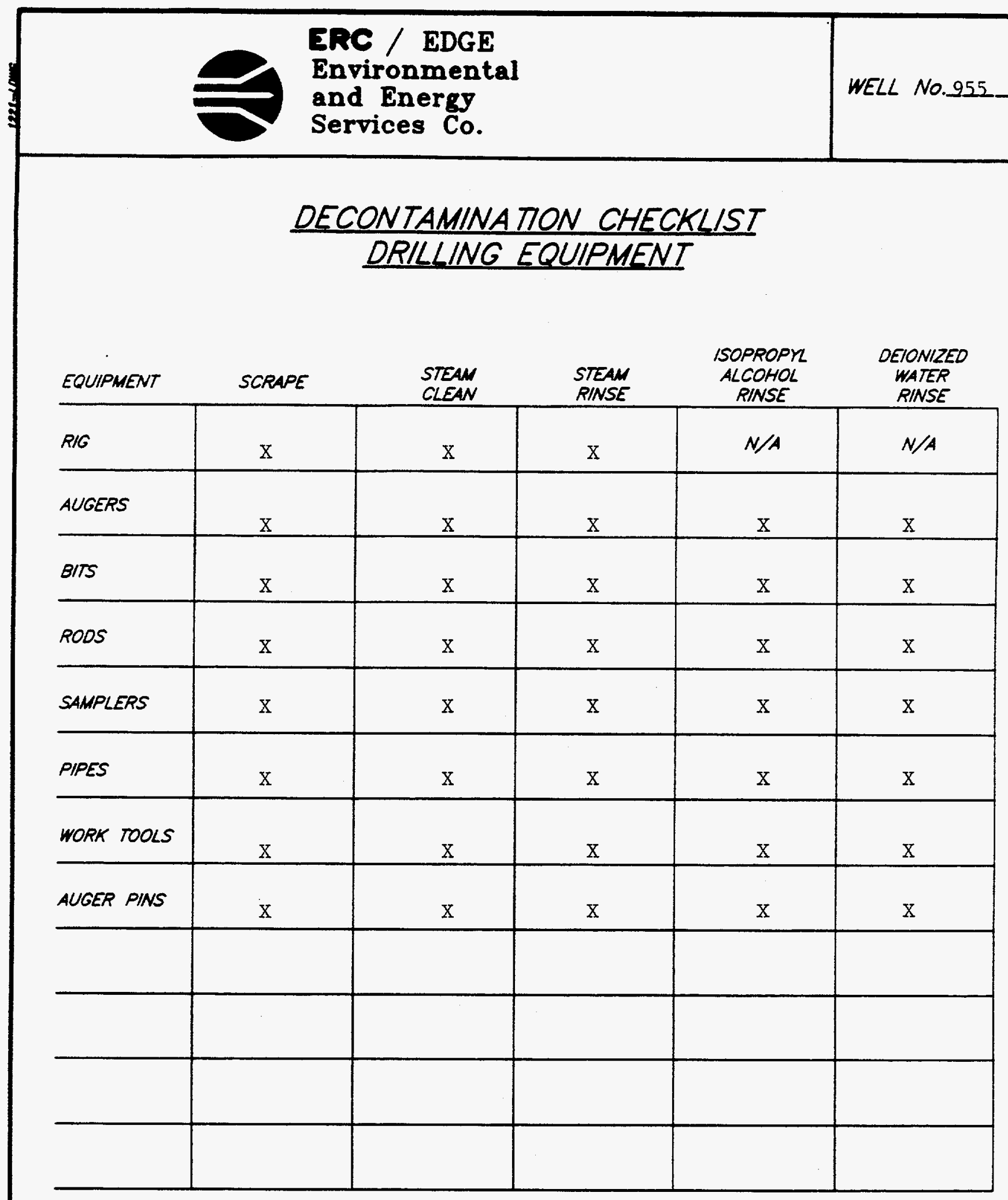

OBSERVER SIGNTURE/DATE $\frac{\text { Axumothe }}{\text { Timothy A. Lee }}$ PAGE 7 OF 16 . 


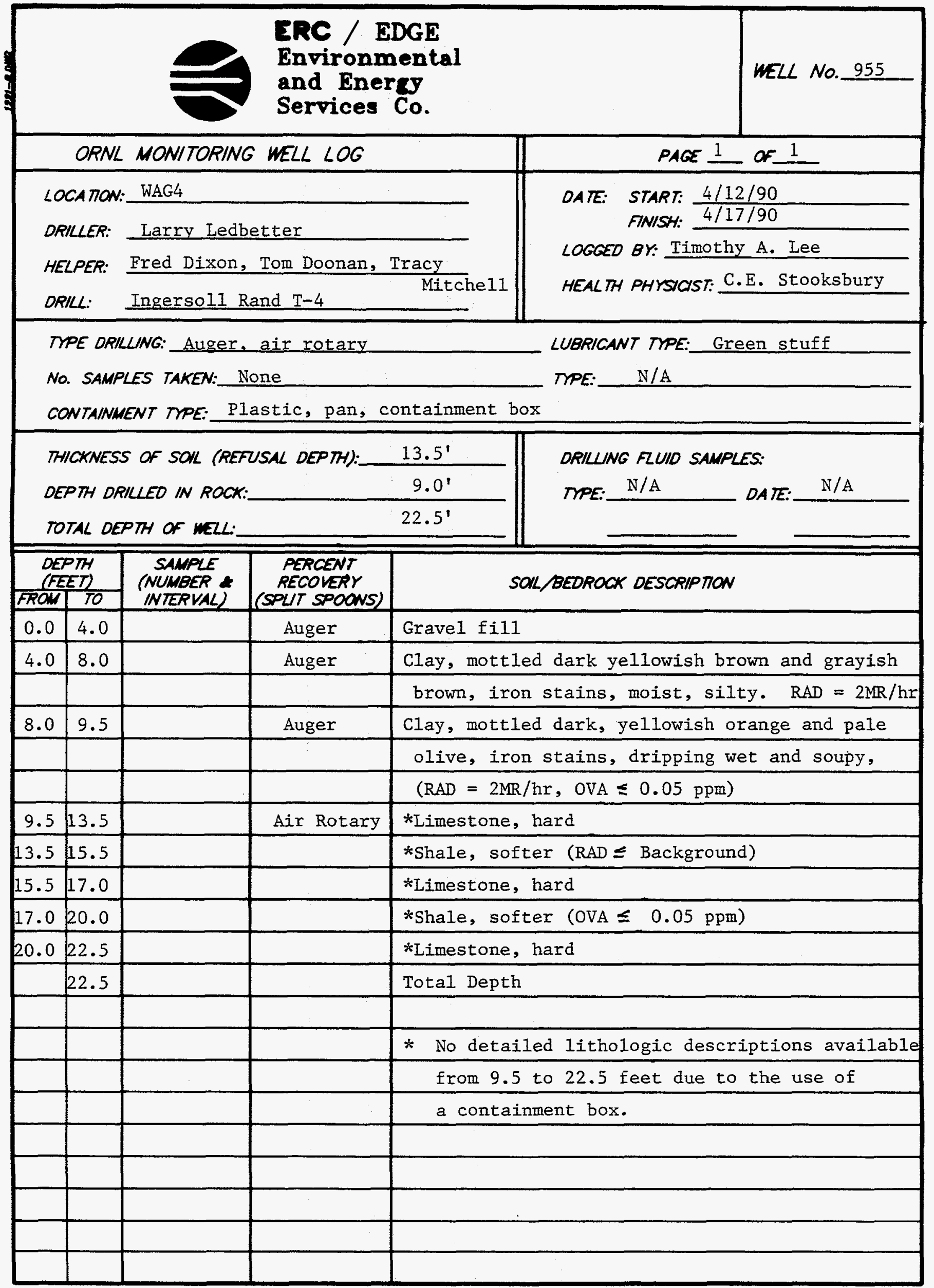




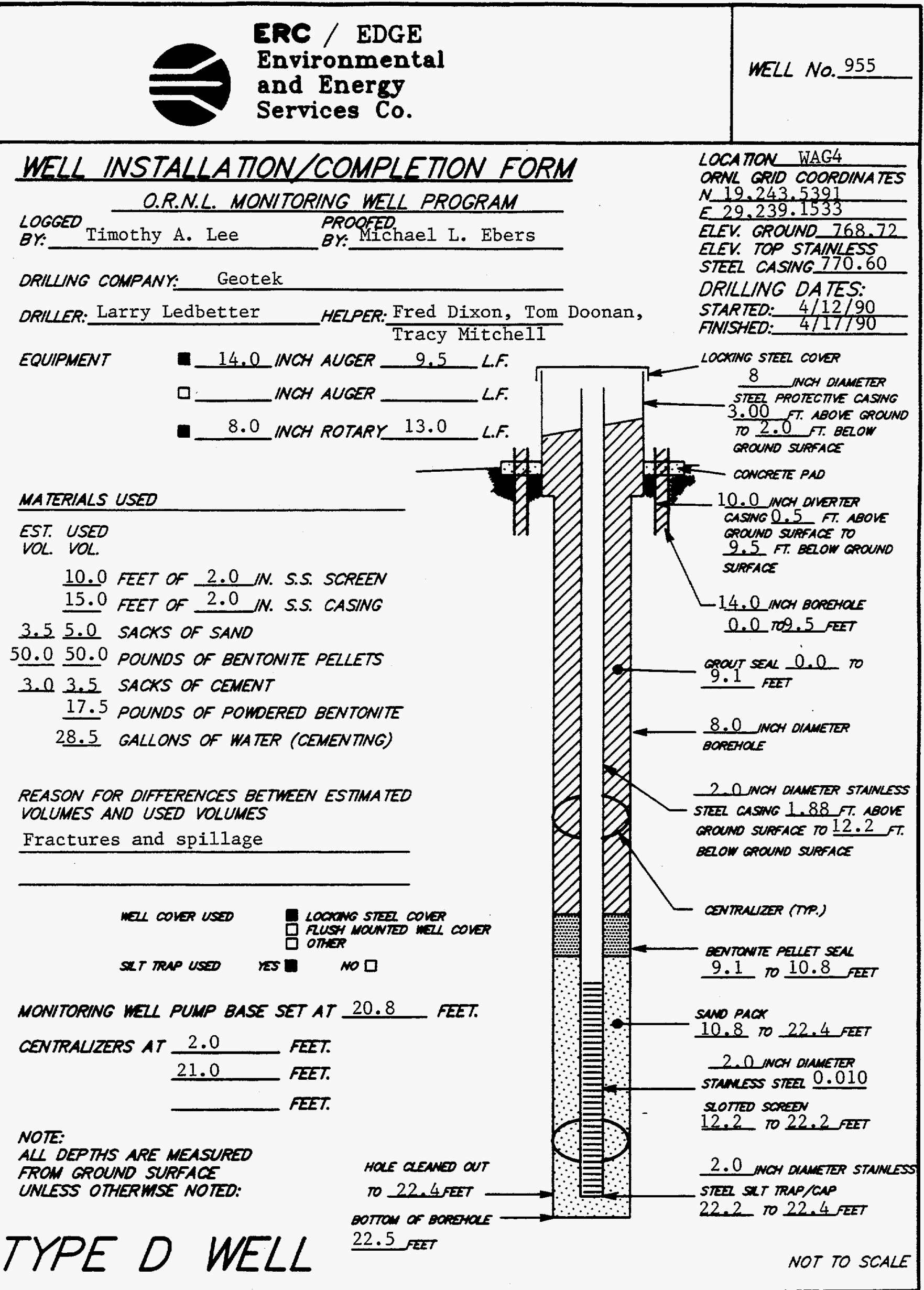


ERC / EDGE

Environmental

WELL NO. 955

and Energy

Services Co.

OATE: $4 / 18 / 90$

MONITORING WELL MATERIALS

CERTIFICATION

ITEM/MA TERIAL

SAND

BENTONITE

STAINLESS STEEL SCREEN

STAINLESS STEEL CASING

STAINLESS STEEL CENTRALIZERS

STAINLESS STEEL CAPS

MONITORING WELL PUMP

GROUT

WELL COVERS

SURFACE CASING

COMMENTS:

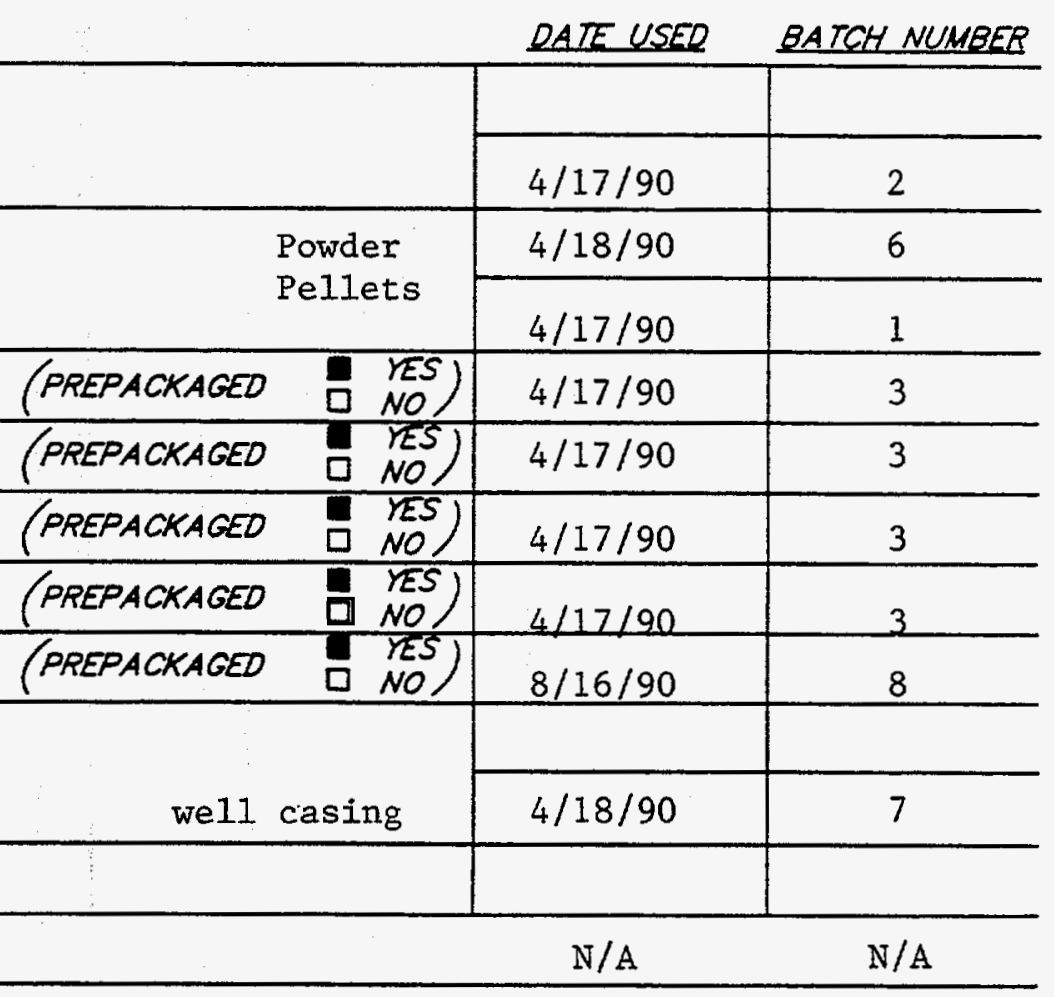




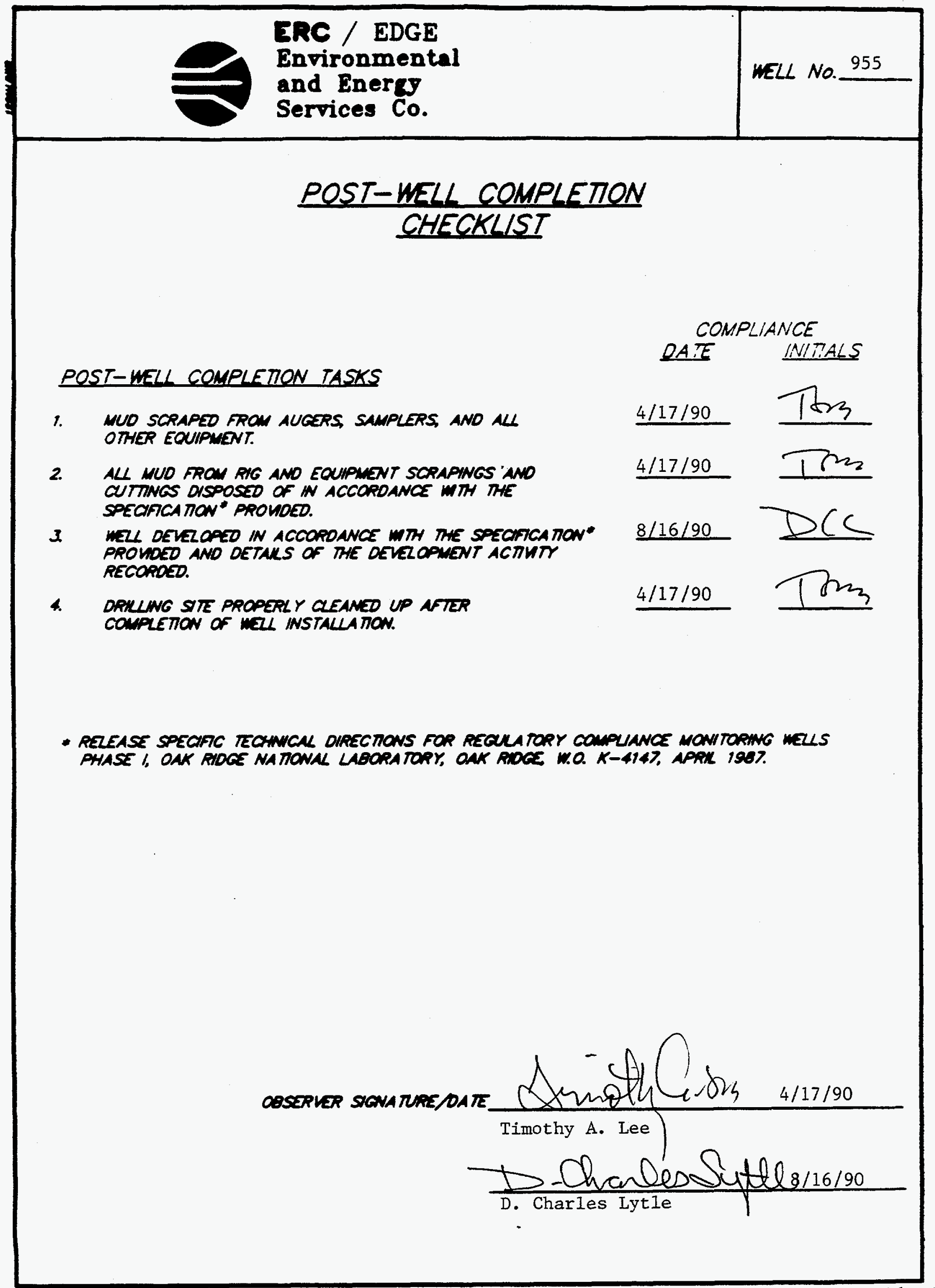

PACE 11 of 16 


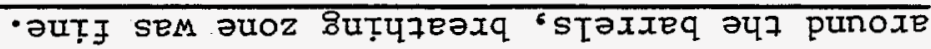

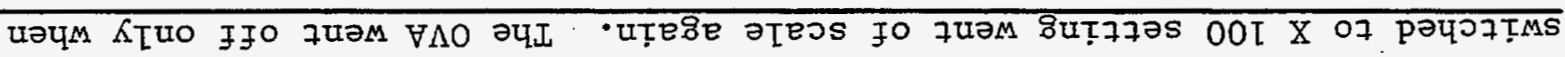

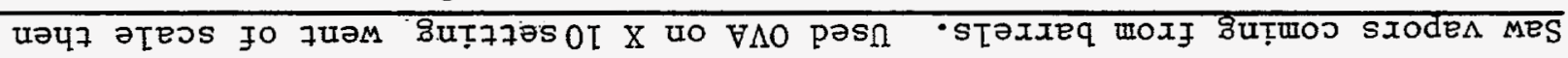

SNOUV1み3580 IN3WdO73130

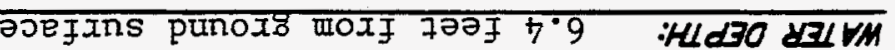
LNGWOOZZ130-3Zd TVUINI

\begin{tabular}{|c|c|c|}
\hline 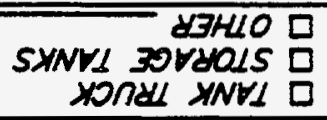 & $\begin{array}{r}\text { smndo } \\
\text { syzuzs mads a } \\
\text { Jorjyns ownodo }\end{array}$ & 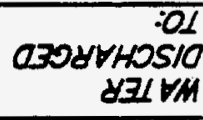 \\
\hline & & \\
\hline
\end{tabular}

$S_{\text {SILN }} 0^{\circ}$ : :

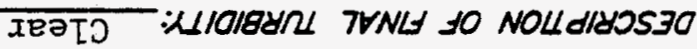

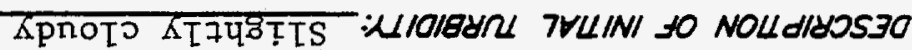

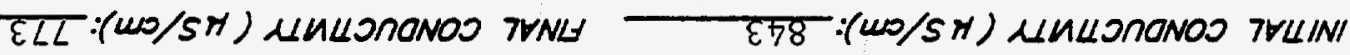
$7 \cdot 8$ :Hd 7WNL

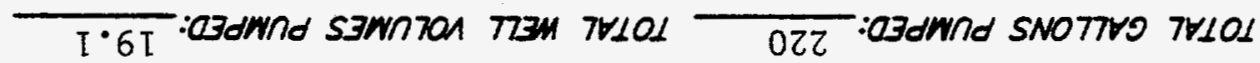
SNO7760- $\varsigma^{\circ I T}: 3 W n 701773 M$ 3NO

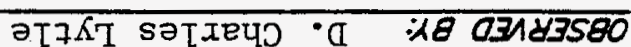
$1 N 3 H 2073130$

\begin{tabular}{lr}
\hline 3IVO SN/ON3 \\
$1 N 3 W d 073130$
\end{tabular}
TTIM DNIYOLINOW

ПTYM : NOU 6007 $\frac{\text { ХәMOI }}{\varsigma \subseteq 6}$. ON $773 \mathrm{M}$
-0 Easuras

Sioug pure

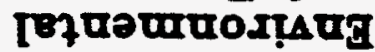


ERC / EDGE

Environmental

and Energy

Services Co.

w2Z No. $\frac{955}{\text { Lower }}$ LOCA NON: WAC4

DATE: $\quad 8 / 13 / 90$

\section{MONITORING WELL DEVELOPMENT PROGRESS}

\begin{tabular}{|c|c|c|c|c|c|c|c|c|c|}
\hline$D A T E$ & $T M M E$ & $\begin{array}{l}\text { Qulars } \\
\text { Penped }\end{array}$ & 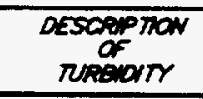 & 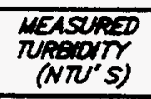 & $\mathrm{pH}$ & $\begin{array}{l}\text { conouc- } \\
\pi n r r \\
(45)\end{array}$ & $\begin{array}{l}\text { TOTRK } \\
\text { GNLOWS } \\
\text { PUNPED }\end{array}$ & $\begin{array}{l}\text { Malu } \\
\text { valumes } \\
\text { Puimed }\end{array}$ & COMMENTS \\
\hline $8 / 13 / 90$ & 1100 & 55 & $\begin{array}{l}\text { Slightly } \\
\text { Cloudy }\end{array}$ & -- & 9.4 & 843 & 55 & 4.9 & $\begin{array}{c}\text { xI0 setting } \\
100 \text { ppm }\end{array}$ \\
\hline $8 / 13 / 90$ & 1300 & 22 & $\begin{array}{l}\text { Slightly } \\
\text { cloudy }\end{array}$ & -- & 2.0 & 849 & 77 & 6.7 & $\begin{array}{c}\text { xilo setting } \\
100 \mathrm{ppm}\end{array}$ \\
\hline $8 / 16 / 90$ & 0815 & 88 & Cloudy & -- & 8.9 & 805 & 165 & 14.3 & $\begin{array}{l}\text { x100 ting } \\
1006 \frac{1 n p m}{p}\end{array}$ \\
\hline $8 / 16 / 90$ & 1300 & 55 & Clear & 4.0 & 8.4 & 773 & 220 & 19.1 & 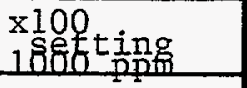 \\
\hline & & & & & & & & & \\
\hline & & & & & & & & & \\
\hline & & & & & & & & & \\
\hline & & & & & & & & & \\
\hline & & & & & & & & & \\
\hline & & & & & & & & & \\
\hline & & & & & & & & & \\
\hline & & & & & & & & & \\
\hline & & & & & & & & & \\
\hline & & & & & & & & & \\
\hline & & 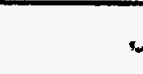 & & & & & & & \\
\hline & & & & & & & & & \\
\hline \multicolumn{2}{|c|}{$\begin{array}{l}\text { RESULTS AT END } \\
\text { OF DEVELOPMENT }\end{array}$} & & Clear & 4.0 & 8.4 & 773 & 220 & 19.1 & $\begin{array}{c}\text { xl00setting } \\
1000 \mathrm{ppm}\end{array}$ \\
\hline
\end{tabular}

COMMENTS Developed well according to specifications, no surging at all. Used

OVA first thing in the morning while they opened well heads checked barrels and

breathing zone and periodically throughout the day while taking water samples.

Only detected contamination coming from the barrels. Could see the vapors. Read $1000 \mathrm{ppm}$ on X100 setting breathing zone was fine. 


\section{HYDRAULIC CONDUCTIVTY CALCULATIONS}

PROGRAM SIUGT, VERSION 4.1, NOV. 1986

THIS PROGRAM CALCULATES MEAN TRANSMISSIVITIES FROM

SLUG-TEST DATA BASED ON TWO ANALYTICAL APPROACHES:

(1) METHOD OF COOPER, BREDEHOEFT AND PAPADOPULOS, 1967 (ARTICLE IN VOL.3, NO. 1 OF WRR ENTITLED

"RESPONSE OF A FINITE DIAMETER WELL TO AN INSTANTANEOUS CHARGE OF WATER")

(2) METHOD OF BOUWER AND RICE, 1976 (ARTICLE IN

VOI. 12, NO.3 OF WRR ENTITLED

"A SLUG TEST FOR DETERMINING HYDRAULIC CONDUCTIVITY OF UNCONFINED AQUIFERS WITH COMPLETELY OR PARTIALLY PENETRATING WELLS")

WELL NO. : 955

PROJECT NO.: E221-002

SITE LOCATION: WAG-4

EDGE, INC. FIELD INVESTIGATOR: JAMES W. CARUTHERS
DATE OF TEST: 10-09-90

CLIENT: MMES

INPUT DATA ARE:

INNER CASING DIAMETER $=2.00$ INCHES

INNER SCREEN OR OPEN-HOLE DIAMETER $=2.00$ INCHES

DIAMETER OF DRILLED HOLE $=8.00$ INCHES

LENGTH OF SCREEN OR INTAKE PORTION $=10.00$ FEET

DEPTH FROM STATIC LEVEL TO BOTTOM OF SCREEN $=17.10$ FEET

THICKNESS OF SATURATED AQUIFER ZONE $=10.00$ FEET

DEPTH TO STATIC WATER LEVEL BELOW REF. POINT $=1.00$ FEET

ESTIMATED POROSITY OF GRAVEL PACK $=.20$

FALLING-HEAD INDEX = 1 ("1" IF FALLING,"0" IF RISING)

NUMBER OF DEPTH-TIME DATA POINTS $=20$

HO WAS COMPUTED FROM INTERCEPT OF PLOT OF LOG(H) VS. TIME

SUCCESSIVE COMPUTED

VALUES FOR HO

(FEET)

2.4339

2.4700 


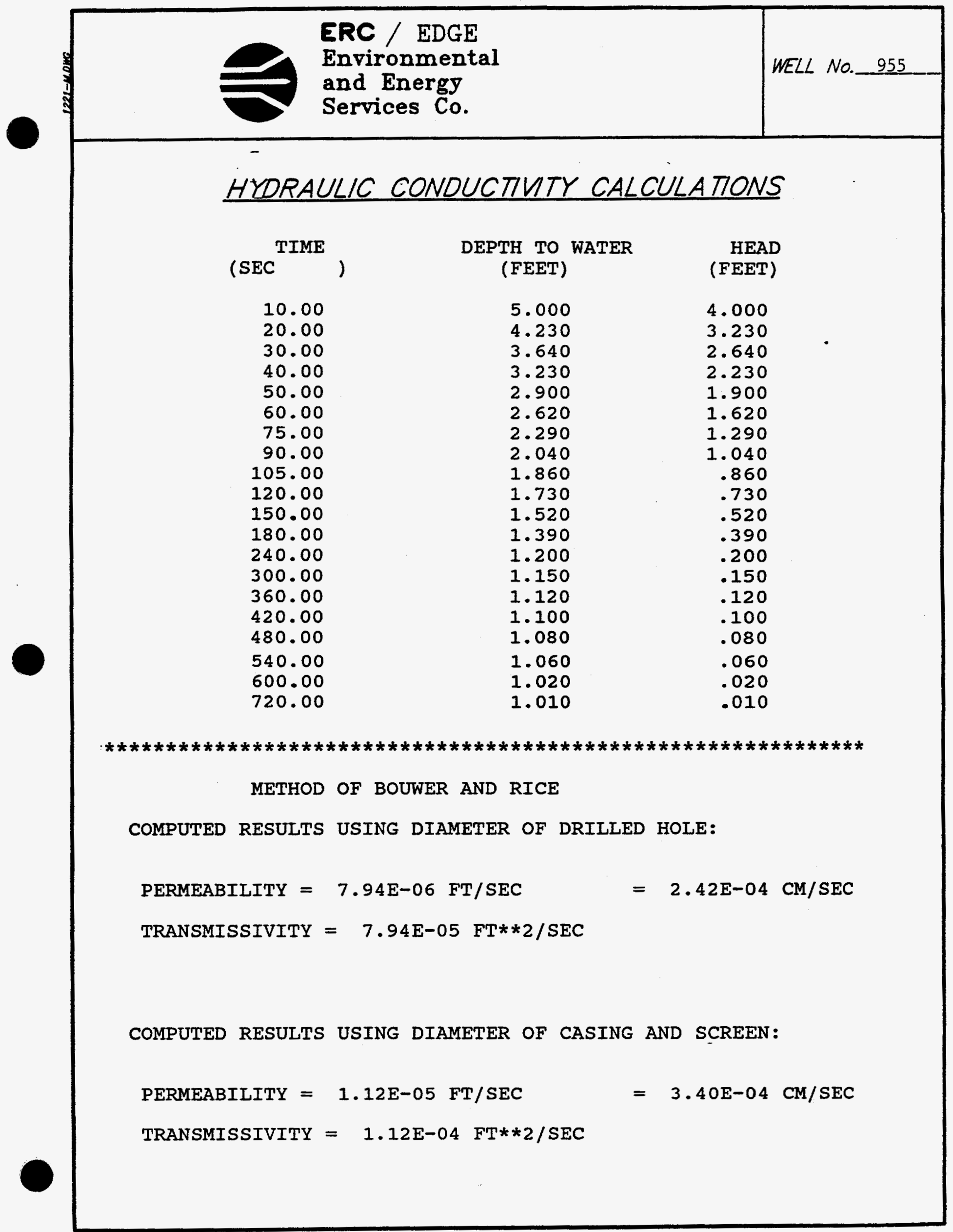

PAGE 15 OF 16. 
ERC / EDGE

Environmental

and Energy

WELL NO. 955

\section{HYORAULIC CONDUCTIVTY CALCULATONS}

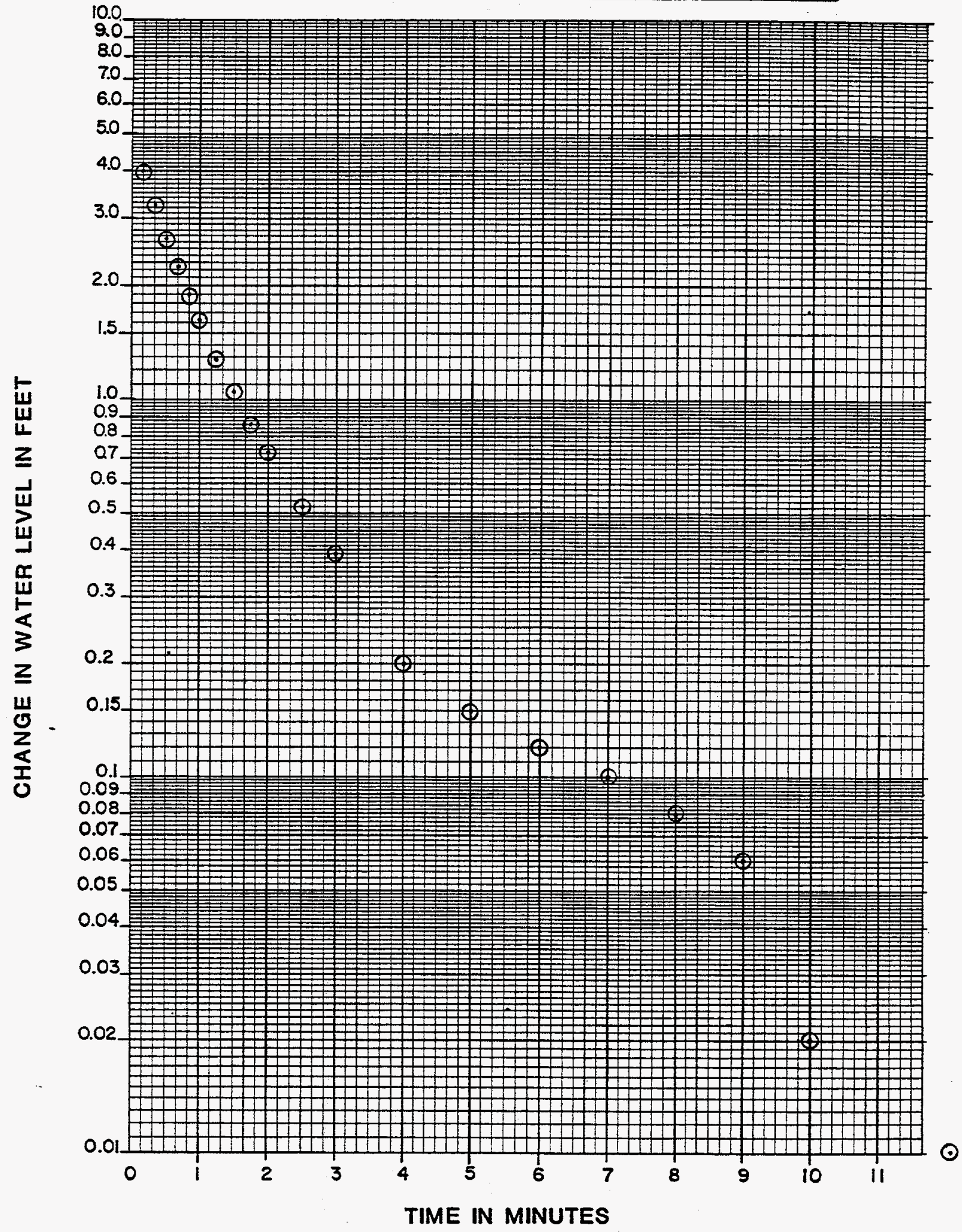

PAGE 16 of 16 
ERC / EDGE

Environmental

and Enerey

Services Co.

1.0 General Information

\subsection{Well Location}

Monitoring well number 956 is located in WAG 4 . It is located approximately 900 feet southwest from the intersection of Melton Valley Drive and Lagoon Road. The location is shown on ORNL drawing number C3E20004A075 Survey coordinates for this well are $N 19,123.7187$, E $29,935.5110(\mathrm{X}-10 \mathrm{grid})$ or latitude $35^{\circ}-55^{\prime}-00.38^{\prime \prime}$ and

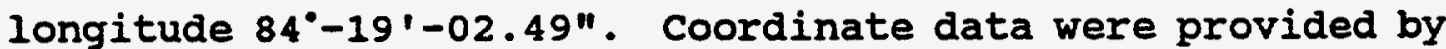
Martin Marietta Energy systems. The method used for conversion from $x-10$ grid to Tennessee-Lambert State Plane Coordinates came from the publication "Tennessee Valley Authority Data Services Branch and Mapping Services Branch, Oak Ridge, Tennessee, DOE Plant Control, November 6, 1985, Field Book: EsS-3115, pp. 1-20." The latitude and longitude were calculated by Adams Craft Herz Walker Engineering, Inc., using methods from the U.S. Coast and Geodetic Survey Publication 62-4, "State Plane Coordinates by Automatic Data Processing."

\subsection{Drilling Information}

Well number 956 was drilled by Geotek Engineering Company. An Ingersoll Rand T-4 rig was used to drill this boring for monitor well installation under the operation of Larry Ledbetter with the assistance of Fred Dixon, Tom Doonan and Tracy Mitchell. Drilling commenced on $4 / 19 / 90$ and was finished on 4/20/90. Paragraph 2.4.1 includes a detailed discussion of the well installation and a well schematic is included on the well installation/completion form. A synopsis of the drilling activity follows. This 
information was typed directly from field notes and was edited only when necessary for clarification.

4/19/90: This location was determined to be Class III. The rig was moved on the staked location and set up on 2 sheets plastic. Split spoon samples were taken from surface to refusal at 13.5 feet (RAD $\leq$ Background, OVA = 30 to $45 \mathrm{ppm}$ ). The boring was augered to refusal at 15.5 feet using a 6 inch auger (RAD $\leq$ Background, OVA $=<0.05$ ppm). The location was down graded to class II. The boring was reamed using a 14.0 inch auger to 7.0 feet (RAD $\leq$ Background, OVA $=<0.5 \mathrm{ppm}$ ). Set 7.0 feet of 10.0 inch decontaminated steel diverter casing and grouted it to surface with 3.0 sacks cement.

4/20/90: Drill from 15.5 to 22.5 feet using an 8.0 inch air rotary tricone bit ( $R A D \leq$ Background, OVA $=$ $0.2 \mathrm{ppm})$. At 22.5 feet while cleaning up hole by blowing, a hole blew out of the surface of the ground approximately 20 feet away from the well bore. A strong sewer gas smell was reported with OVA-readings of $>100 \mathrm{ppm}$. Immediately shut down drilling operations and moved workers up wind. The gas dissipated rapidly to ova readings of less than $0.5 \mathrm{ppm}$. Therefore, removed drill steel from well, set 2 inch stainless steel screen, and casing with sandpack and bentonite seal. Grouted annulus with 3.0 sacks cement. 
ERC / EDGE

Environmental

and Enercy

Services Co.
Monitaens MIL PROCRM

WII OATA NARRATVE

uzL Na 956

This well was logged by ERC Environmental and Energy Services Co. (ERC) hydrogeologist Timothy A. Lee. All well construction materials and supplies were from Martin Marietta Energy Systems approved batches. The batch origin of individual items is shown on the included Monitoring Well Materials Certification form.

2.0 Technical Information

\subsection{Decontamination Procedures}

The drilling rig, down hole tools, surface casing, stainless steel screen, stainless steel casing, centralizers, and stainless steel silt trap underwent the cleaning decontamination procedures outlined in the drilling specifications (Release specific Technical Directions for Regulatory Compliance Monitoring Wells Phase 1, Oak Ridge National Laboratory, Oak Ridge, w.0. K-4147, April 1987, pgs. 2-4). A checklist of the cleaned materials is included with this data package.

\subsection{Geology}

WAG 4 is located in Melton Valley which is in the valley and Ridge Physiographic Province of East Tennessee. WAG 4 is underlain by shale, siltstone, and limestone of the Middle to Upper Cambrian Conasauga Group. The Conasauga Group in the Oak Ridge area consists of six formations. They are, in ascending order, the Pumpkin Valley Shale, Rutledge Limestone, Rogersville Shale, Maryville Limestone, Nolichucky shale and the Maynardville Limestone. The pumpkin Valley Shale and Rutledge Limestone underlie WAG 4. strike in and near WAG 4 ranges from $\mathrm{N} 85^{\circ} \mathrm{E}$ to $\mathrm{N} 15^{\circ} \mathrm{E}$ and 
dip varies from $27^{\circ}$ to vertical. These variations in strike and dip indicate that the conasauga has been deformed in the locale of WAG 4.

\subsection{Sample collection}

A bulk density soil sample was collected from the split spoon sample interval from 4.3 to 4.6 feet. The sample was measured and weighed, and a bulk density of $2.08 \mathrm{grams} / \mathrm{cm}^{3}$ was calculated. No samples were collected for chemical analysis.

\subsection{Installation and Development}

\subsubsection{Installation}

This was a Type D well. A 6-inch diameter boring was split spooned and augered from ground surface to auger refusal (13.5 feet). The air rotary method was required to complete the boring to the specified total well depth. Therefore, a 14..0-inch diameter boring was augered from ground surface to 7.0 feet and a 10.0-inch diameter diverter casing was installed and grouted. An 8-inch diameter boring was then drilled with an air rotary tricone roller bit from 7.0 to 22.5 feet. A 2 -inch diameter stainless steel screen with-threaded bottom cap was installed from 12.3 to 22.5 feet. A 2-inch diameter stainless steel casing was installed above the screen at 12.3 feet and extended 2.7 feet above ground surface. A sandpack was then tremied into the annular space from 9.0 to 22.5 feet, with a 1.5 -foot bentonite pellet seal poured into the annular space above the sandpack from 7.5 to 9.0 feet. The annular space from the top of the bentonite seal 
ERC / EDGE

Environmental

and Energy

Services Co.

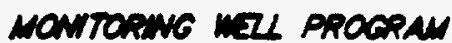

MII OATA NAARATIVE

mal $\mathrm{Na} 956$

to the surface was tremie-grouted with a cement/bentonite slurry. A detail of the well is included on the well installation/completion form.

\subsubsection{Well Development}

Well number 956 was developed to remove drill cuttings, silt, and other fines. The monitoring well was developed using a Geoguard pump with an air compressor. All pumps were cleaned prior to use according to specified cleaning procedures (see Paragraph 2.1). The well was developed until a measured total of 270 gallons of water had been evacuated and the clarity of the discharge water was approved by the company representative. The final turbidity value measured at completion was $>100$ NTU's. A development form showing the exact method of development and other pertinent data is appended.

\subsubsection{Installation of Dedicated Monitoring Well Pump}

After the well was developed, a Geoguard Model No. 5614 dedicated monitoring well pump was installed on 8/17/90 at a depth of 19.7 feet below ground surface. These pumps are decontaminated at American Sigma and are sent prepackaged. A copy of the pump certification is kept on file at ORNL.

\subsection{Hydraule Conductivity Testing}

Well number 956 was tested for the determination of hydraulic conductivity of the aquifer in the vicinity of the well screen. This was accomplished by instantaneously adding a known quantity of water to the monitoring well and measuring the recovery of the water level over time. The 


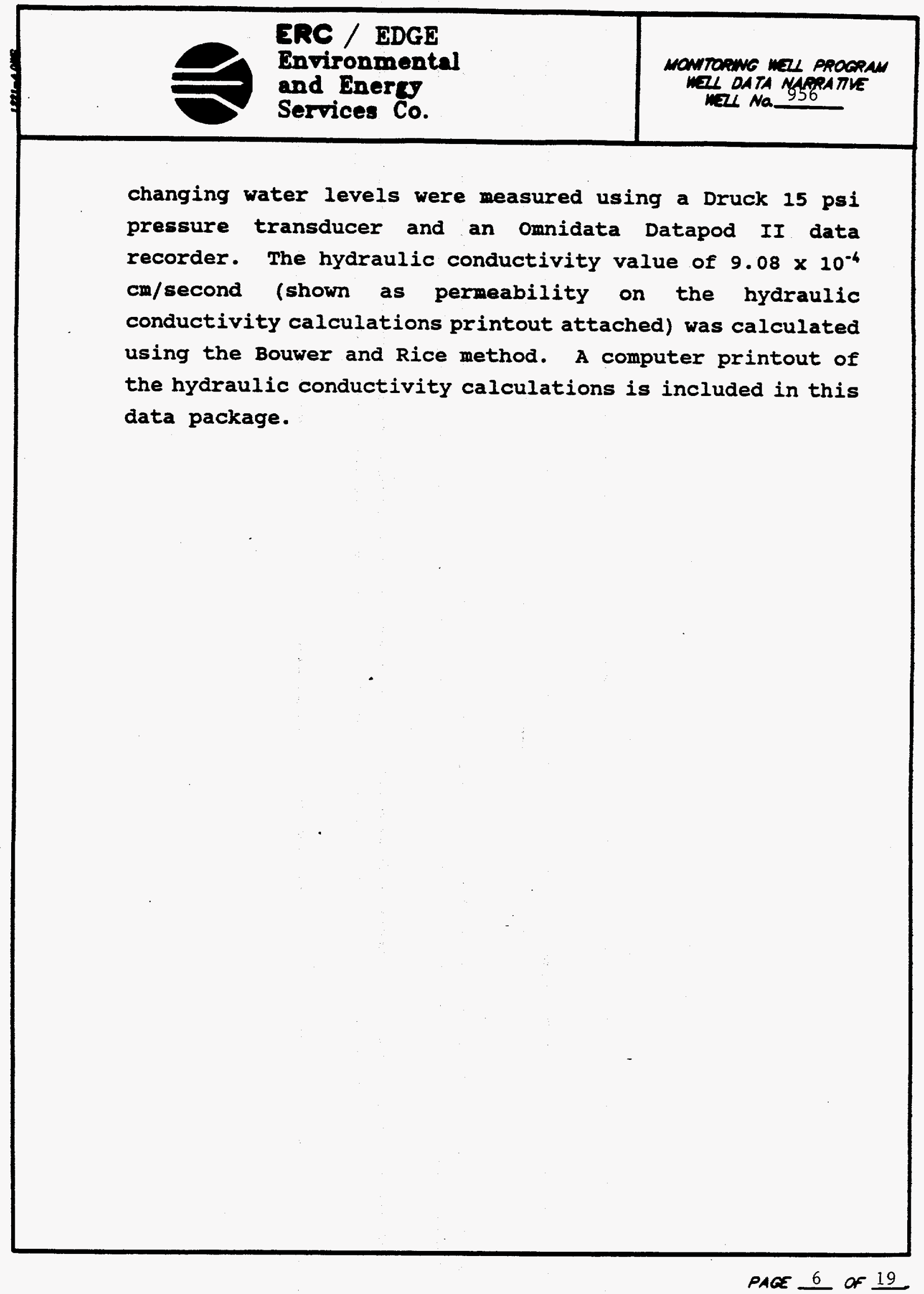


ERC / EDGE

Environmental

and Enerey

Services Co.

\section{PRE-DRILLING CHECKLIST FOR MONITORING WELLS}

RRE-DRILUNG TASKS

1. EXCAVTTON PERMIT OBTAINED

2. ALL EQUIPMENT HAS BEEN CLEANED BEFORE DRILLING.

30. SCREEN AND CASING HAVE BEEN WASHED, STEAMED, RINSED WTH DE-IONIZED OR DISTLLED WATER, RINSED WTH ISOPROPK ALCOHOL, WRAPPED WTH PROTECTVE COVERING AND STORED OFF THE GROUND.

36. PRE-PACKAGED SCREENS, CASING AND CENTRALIZERS WERE USED.

4. WORK AREA FOR SAMPLE EXAMINATION COVERED WTH CLEAN POL YETHRENE.

5. CLEAN KNIVES, GLOVES, SAMPLE JARS AND LABELS ON HAND.

6. POLYETHIENE COVER IN PLACE OVER HOLE.

7. AIR ROTARY COMPRESSED AIR SAMPLED.
COMPLIANCE

DATE

$4 / 19 / 90$

INITALS

$4 / 19 / 90$

$7_{2}$

$\mathrm{N} / \mathrm{A}$

$\mathrm{N} / \mathrm{A}$

$4 / 20 / 90$

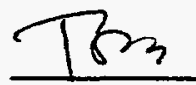

$4 / 20 / 90$

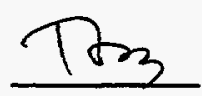

$4 / 20 / 90$

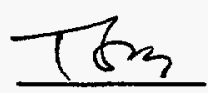

$4 / 20 / 90$

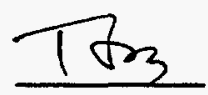

$4 / 20 / 90$

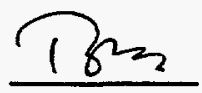

RESULTS: No detectable signs of hydrocarbons under ultraviolet light.

ADDITONAL NOTES/OBSERVATIONS:

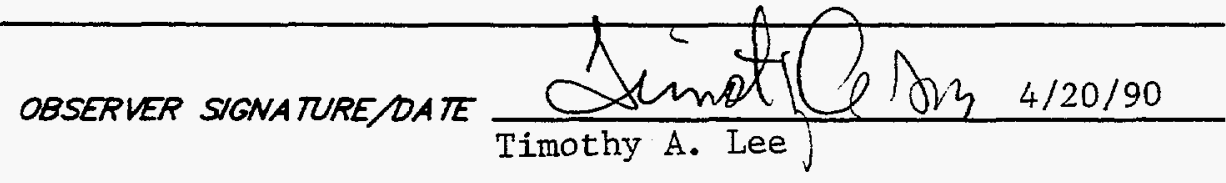

PAGE 7 OF 19 . 
ERC / EDGE

Environmental

and Energy

WELL NO._956

Services Co.

DECONTAMINATION CHECKLIST

DRILLING EQUIPMENT

\begin{tabular}{|c|c|c|c|c|c|}
\hline EQUIPMENT & SCRAPE & $\begin{array}{l}\text { STEAN } \\
\text { CLEAN }\end{array}$ & $\begin{array}{l}\text { STEAM } \\
\text { RINSE }\end{array}$ & $\begin{array}{c}\text { ISOPROPYL } \\
\text { ALCOHOL } \\
\text { RINSE }\end{array}$ & $\begin{array}{c}\text { OEIONIZED } \\
\text { WATER } \\
\text { RINSE }\end{array}$ \\
\hline RIG & $\mathrm{X}$ & $\mathrm{X}$ & $\mathrm{X}$ & $N / A$ & $N / A$ \\
\hline AUGERS & $\mathrm{x}$ & $\mathrm{X}$ & $\mathrm{x}$ & $x$ & $\mathrm{X}$ \\
\hline BITS & $\mathrm{X}$ & $\mathrm{X}$ & $x$ & $\mathrm{X}$ & $\mathrm{X}$ \\
\hline ROOS & $\mathrm{x}$ & $\mathrm{x}$ & $\mathrm{x}$ & $\mathrm{x}$ & $\mathrm{x}$ \\
\hline SAMPLERS & $\mathrm{x}$ & $\mathrm{X}$ & $x$ & $\mathrm{X}$ & $\mathrm{x}$ \\
\hline PIPES & $\mathrm{x}$ & $\mathrm{x}$ & $\mathrm{X}$ & $\mathrm{x}$ & $\mathrm{x}$ \\
\hline WORK TOOLS & $\mathrm{X}$ & $\mathrm{X}$ & $x$ & $\mathrm{X}$ & $\mathrm{X}$ \\
\hline AUGER PINS & $\mathrm{X}$ & $x$ & $\mathrm{x}$ & $x$ & $x$ \\
\hline & & & & & \\
\hline & & & & & \\
\hline & & & & & \\
\hline
\end{tabular}

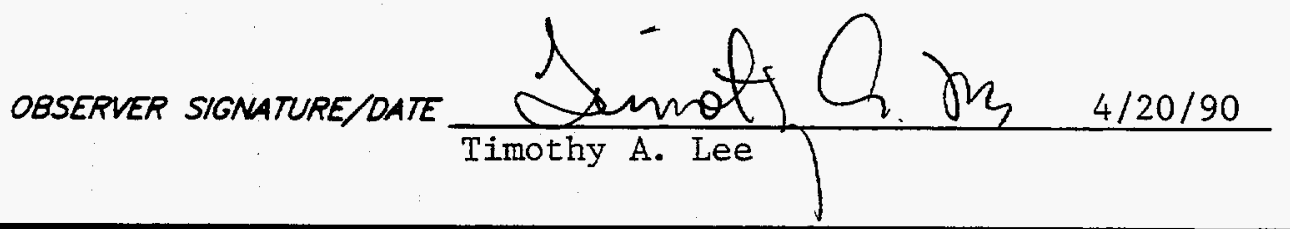




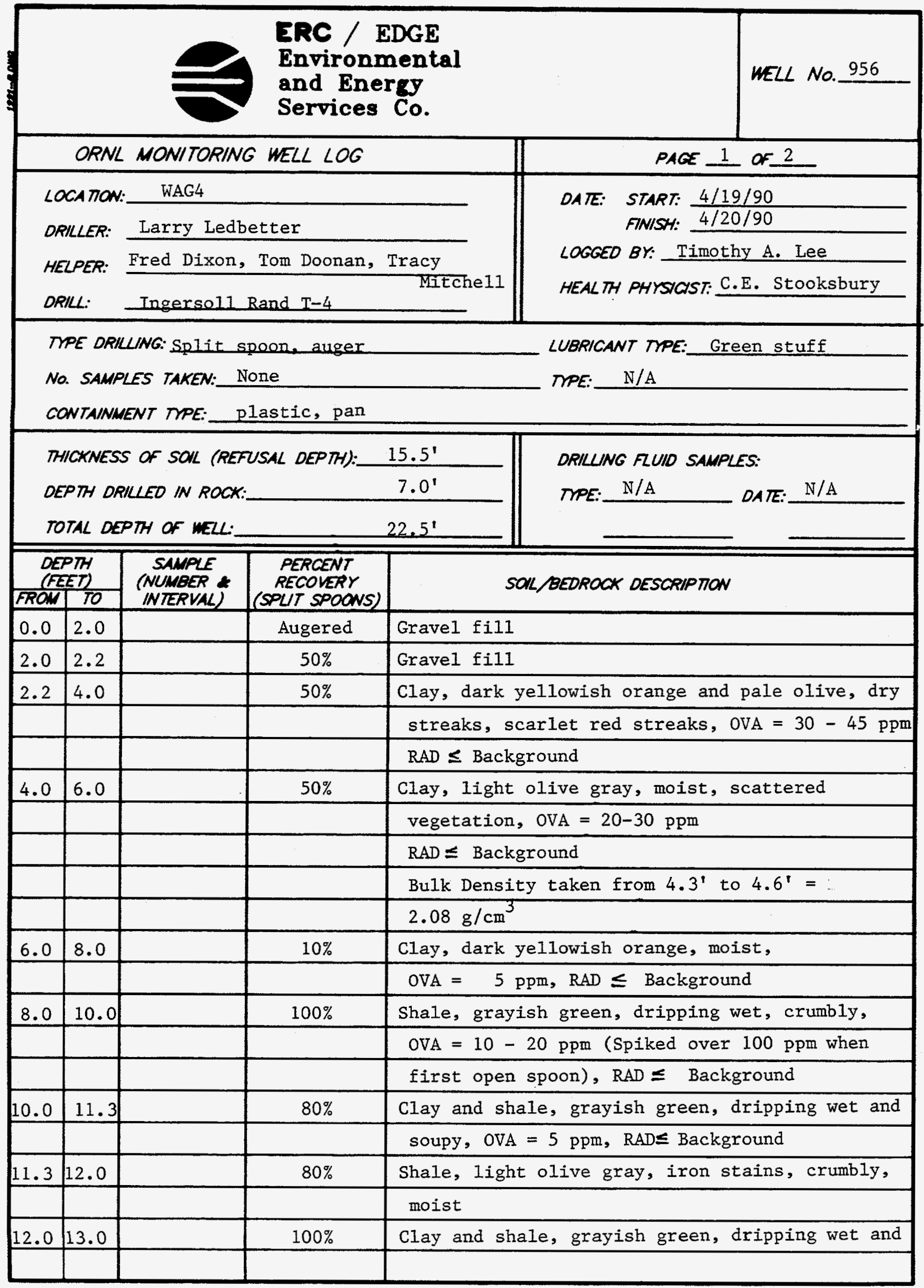




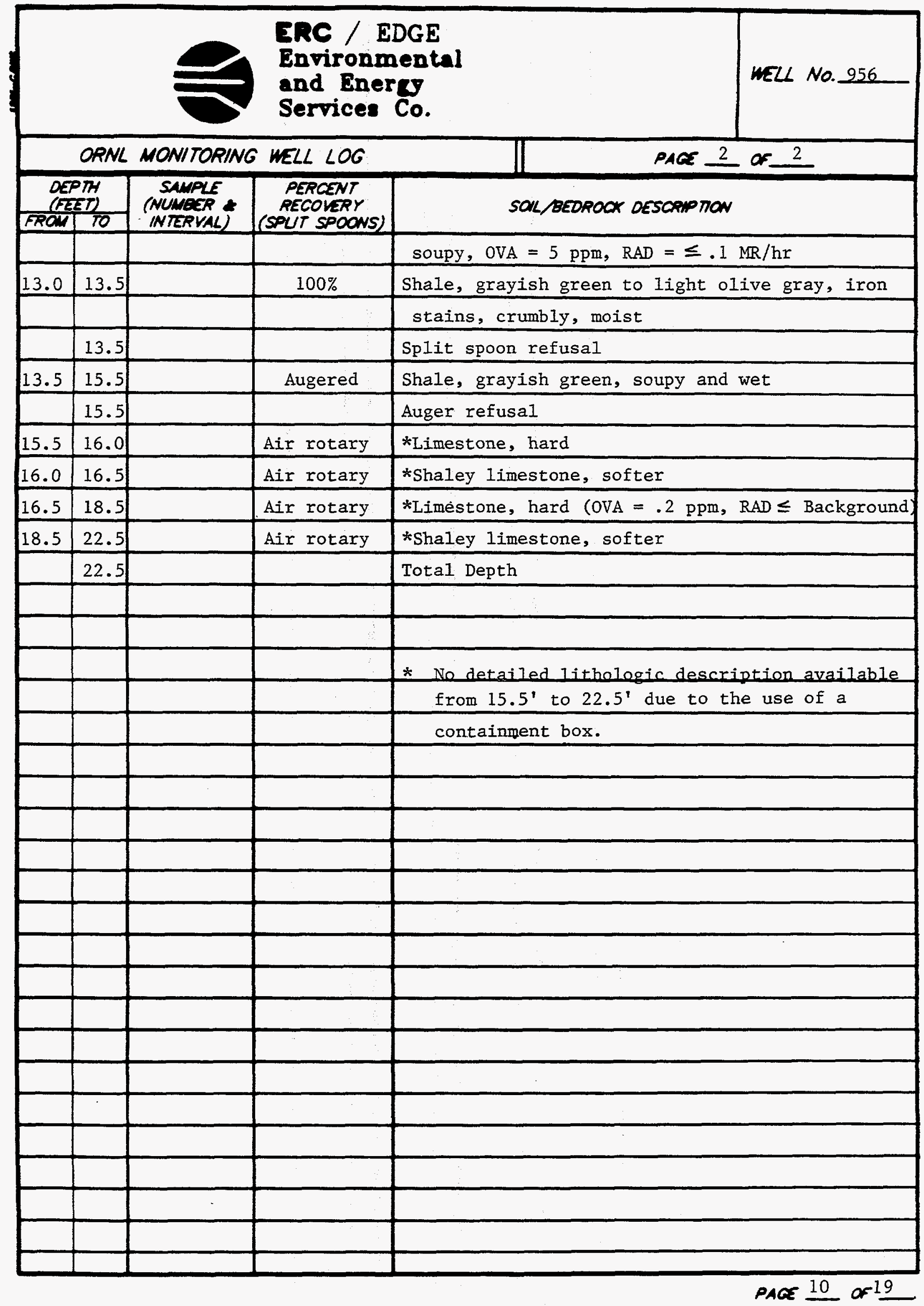


WELL INSTALLATION/COMPLETION FORM

and Energy

Services Co.

\begin{tabular}{lc} 
& O.R.N.L. MONITORING WELL PROGRAM \\
\cline { 2 - 3 } LOGGED & PROOFED \\
BY: Timothy A. Lee & BY:_Michael_L. Ebers
\end{tabular}

DRILUNG COMPANY: Geotek

ORILER: Larry Ledbetter

HELPER: Fred Dixon, Tom Doonan Tracy Mitchell

EQUIPMENT

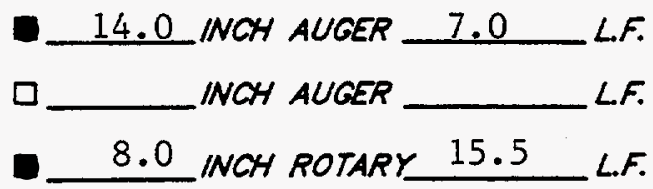

MATERIALS USED

EST. USEO

VOL. VOL.

10.0 FEET OF 2.0 IN. S.S. SCREEN

15.0 FEET of 2.0 IN. S.S. CASING

3.37 .0 SACKS OF SAND

50.0 50.0POUNOS OF BENTONITE PELLETS

1.53 .0 SACKS OF CEMENT

15.0 POUNDS OF POWOERED BENTONITE

24.0 GALLONS OF WATER (CEMENTNG)

REASON FOR DIFFERENCES BETWEEN ESTMATED

VOLUMES AND USED VOLUMES

Fractures, irregular boring diameter

and spillage

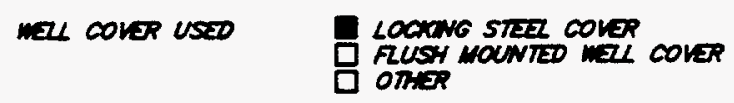

SET TRN USD RE NON NON

MONITORING WELL PUMP BASE SET AT 19.7 FEET.

CENTRALIZERS AT 2.0 FEET.

FEET.

NOTE:

ALL DEPTHS ARE MEASURED

FRON GROUND SURFACE

UNLESS OTHERMSE NOTED:

TYPE D WELL
HOL CEANBD OUT

To 22.5 न्या 22.5 चET
LOCATON WAG4

ORNL GRID COOROINATES

$N 19.123 .7187$

E $28,935.5110$

ELEV. GROUND 774.04

ELEV. TOP STAINLESS

STEEL CASING 776.00

DRILLING DATES:

STARTED: $4 / 19 / 90$

FINISHED: 4/20/90

LOOXTEG STER COVER

8 NOH OIAMETER STER PROTECTVE CASNG 3.08 FT. ABOVE OROUND To 2.0 FT. BEZOW CROUNO SURFACE

VI: CONORETE PAD

10.0 NOH DVERTER GASING 0.0 FT. ABOVE GROUNO SURFACE TO 7.0 FT. BEZOW GROUND SURFACE

-14.0 NOH BOREHOLE 0.0 ro. 0 FEE

CROUT SEN 0.0 TO 7.5 FEET

8.0 NOH OIANETER BCREHOLE

2.0 NOH OLAWETER STAINLESS STER CASNG 1.96 fT. AOOVE EROUNo suRACE To 12.3 T. ezon CROUNO SUAFACE

CSNTRALZSR (TMP.)

BSNTONTE PEZLET SEN

7.5 TO 9.0 FEET

Syo pacx 22.5 TEET

2.0 NOH DHNETER stancess stzz $\underline{0.010}$ SLTIED SOREDV 12.3 To 22.3 FET

2. ONOH DAMETER STANLESS STEZ STT TRAP/CAP 22.3 T0 22.5 चE्ड 
ERC / EDGE

Environmental

WELL NO._956

and Energy

Services Co.

DATE: $4 / 20 / 90$

\section{MONITORING WELL MATERIALS}

\section{CERTIFICATION}

ITEM/MA TERIAL

\begin{tabular}{|c|c|c|}
\hline & DATE USED & BATCH NUMBER \\
\hline & $4 / 20 / 90$ & 2 \\
\hline Powder & $4 / 20 / 90$ & 6 \\
\hline & $4 / 20 / 90$ & 1 \\
\hline KAGED $0 \begin{array}{c}\text { YES } \\
\text { NO }\end{array}$ & $4 / 20 / 90$ & 3 \\
\hline $\begin{array}{ccc}\text { KAGED } & \text { YES } \\
& \square & N O\end{array}$ & $4 / 20 / 90$ & 3 \\
\hline KAGED $\left(\begin{array}{cc}\text { YES } \\
\text { NOO }\end{array}\right)$ & $4 / 20 / 90$ & 3 \\
\hline KAGED $\left(\begin{array}{c}\text { YES } \\
\text { NO }\end{array}\right)$ & $4 / 20 / 90$ & 3 \\
\hline $\left.\begin{array}{ccc}\text { KAGED } & \text { YES } \\
\text { NO }\end{array}\right)$ & $8 / 17 / 90$ & 8 \\
\hline Diverter & $4 / 19 / 90$ & 7 \\
\hline well casing & $4 / 20 / 90$ & 7 \\
\hline
\end{tabular}

BENTONITE

N/A

N/A

COMMENTS:

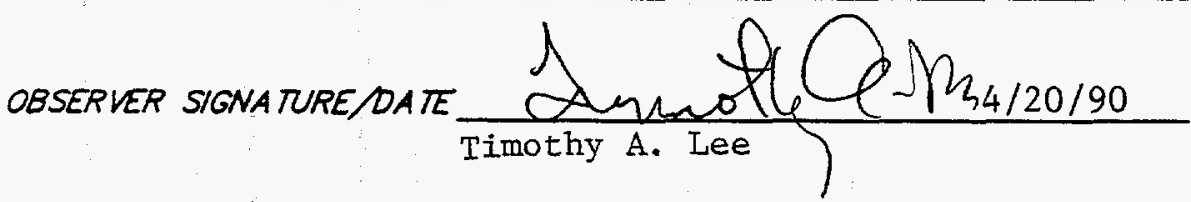

PAGE 12 OF 19. 


\section{POST-MELL COMPLETION CHECKLIST}

\section{POST-MELL COMPLETION TASKS}

1. WUD SCPAPED FRON AUEERS SMMPLERS ANO ALL OTHER EOUPAENT.

2. ALL WUO FROW RIG AND EQUIPUENT SCRAPINGS ANO CUTINAS OSPOSED OF IN ACCORDANCE MTH THE SPEAFTCA IION" PROWOED.

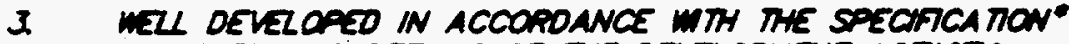
PROWDED AND OETAKS OF THE OEKZLOMENT ACIUT RECOROED.

4. ORULWG STE PROPERLY CLEANED UP AFTER COMPLETION of nzL INSTALLATION.

COMPLIANCE

\section{DATE INITALS}

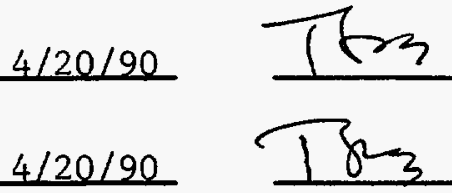

$8 / 17 / 90$

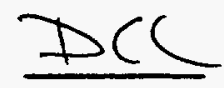

$4 / 20 / 90$

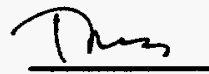

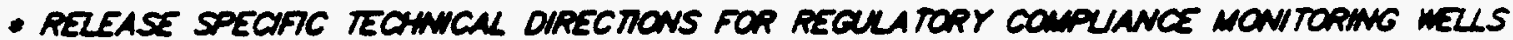

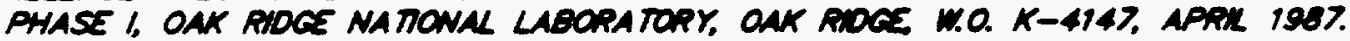

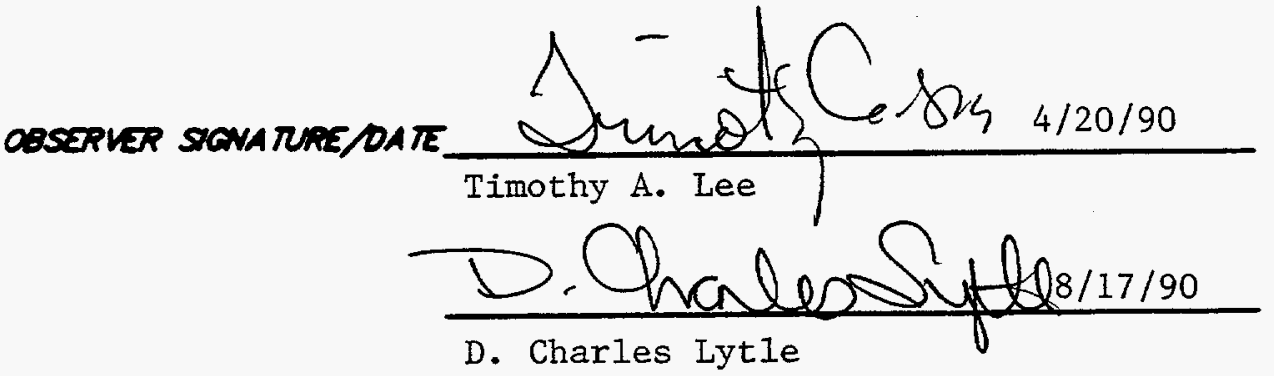




\section{MONITORING WELL \\ DEVELOPMENT FORM}

\section{DEVELOPMENT DETAILS}

METHOD OF

OEVELOPMENT: Pumping with Geoguard pump

DEVELOPMENT

BEGAN DATE: $\quad 8 / 13 / 90$ TME:

DEVELOPMENT

ENDING DATE: $\quad 8 / 17 / 90$

OEVELOPMENT

OBSERVED BY: D. Charles Lytle

ONE WELL VOLUME:_ 8.5

GALLONS

TOTAL GALLONS PUMPED: 270 TOTAL WELL VOLUMES PUMPED:31.7

INIMAL PH: 8.1 FNAL PH: 7.8

INITAL CONDUCTUTY (KS/Cm): 797 FNAL CONOUCTUTY ( $\mathrm{HS} / \mathrm{cm}): 747$

DESCRIPTION OF INITAL RURBIDITY: ClOUdV

DESCRIPTION OF FINAL TURBIDITY: Slightly Cloudy

FINAL MEASURED TURBIDITY: $100 \mathrm{NTU}^{\prime} \mathrm{s}$

\begin{tabular}{|c|c|c|}
\hline $\begin{array}{l}\text { ODOR } \\
\text { Of WATER: }\end{array}$ & None & \\
\hline $\begin{array}{l}\text { WA TER } \\
\text { DISCHARGED } \\
\text { TO: }\end{array}$ & $\begin{array}{l}\text { GROUND SURFACE } \\
\text { LTORM SEWERS } \\
\text { ORUMS }\end{array}$ & $\begin{array}{l}\text { ㅁ TANK TRUCK } \\
\text { STORAGE TANKS } \\
\text { 口 OTHER }\end{array}$ \\
\hline
\end{tabular}

INITAL PRE-DEVELOPMENT

WA TER DEPTH: 3.8 feet from ground surface

\section{DEVELOPMENT OBSERVATIONS}

Vapors were coming from barrels. Used OVA at x10 setting pegged instrument. Water came out in sample tube clean within 5 to 10 minutes. Changed to a yellow-orange color. Collected liter bottle sample to have analyzed. 
ERC / EDGE

Environmental

and Energy

Services Co.
mzL No. $\frac{956}{\text { Lower }}$ LOCA IION: WAG4

OATE: $8 / 13 / 90$

\section{MONITORING WELL DEVELOPMENT PROGRESS}

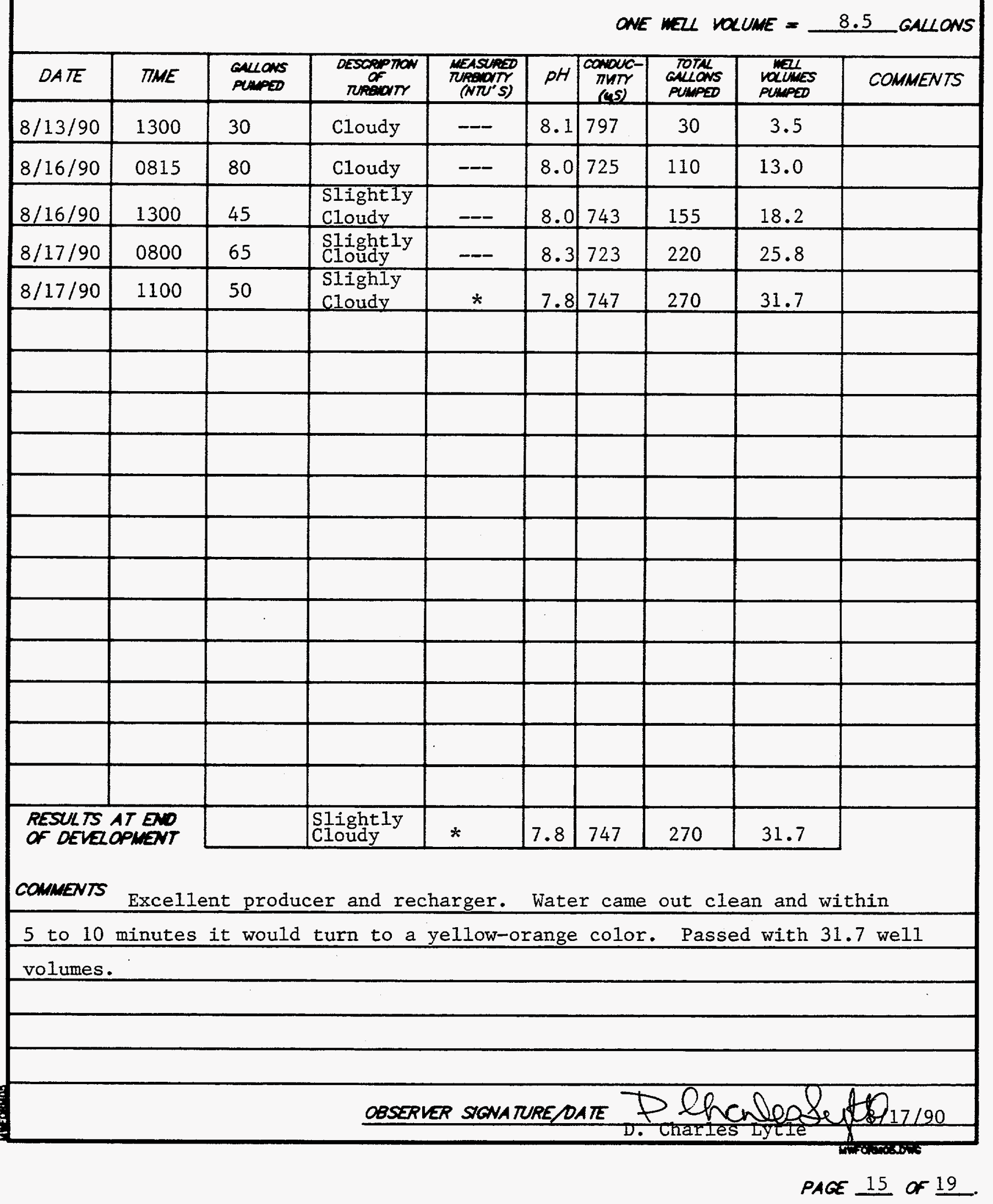




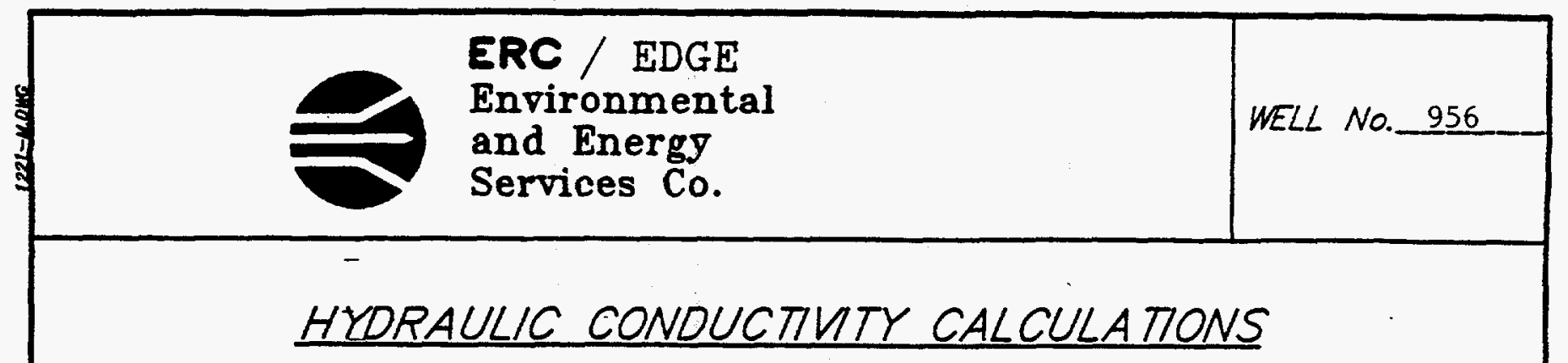

PROGRAM SLUGT, VERSION 4.1, NOV. 1986

THIS PROGRAM CALCULATES MEAN TRANSMISSIVITIES FROM

SLUG-TEST DATA BASED ON TWO ANALYTICAL APPROACHES:

(1) METHOD OF COOPER, BREDEHOEFT AND PAPADOPULOS, 1967

(ARTICLE IN VOL.3, NO.1 OF WRR ENTITLED

"RESPONSE OF A FINITE DIAMETER WELL TO AN INSTANTANEOUS CHARGE OF WATER")

(2) METHOD OF BOUWER AND RICE, 1976 (ARTICLE IN

VOL. 12, NO.3 OF WRR ENTITLED

"A SLUG TEST FOR DETERMINING HYDRAULIC CONDUCTIVITY

OF UNCONFINED AQUIFERS WITH COMPLETELY OR PARTIALIY PENETRATING WELLS")

WELL NO.: 956

DATE OF TEST: $10-09-90$

PROJECT NO.: E221-002

CLIENT: MMES

SITE LOCATION: WAG-4

EDGE, INC. FIELD INVESTIGATOR: JAMES W. CARUTHERS

INPUT DATA ARE:

INNER CASING DIAMETER $=2.00$ INCHES

INNER SCREEN OR OPEN-HOLE DIAMETER $=2.00$ INCHES

DIAMETER OF DRILLED HOLE $=8.00$ INCHES

LENGTH OF SCREEN OR INTAKE PORTION $=10.00$ FEET

DEPTH FROM STATIC LEVEL TO BOTTOM OF SCREEN $=18.60$ FEET

THICKNESS OF SATURATED AQUIFER ZONE $=10.00$ FEET

DEPTH TO STATIC WATER LEVEL BELOW REF. POINT $=1.00$ FEET

ESTIMATED POROSITY OF GRAVEL PACK $=.20$

FALLING-HEAD INDEX $=1$ ("1" IF FALLING, "O" IF RISING)

NUMBER OF DEPTH-TIME DATA POINTS $=19$ 


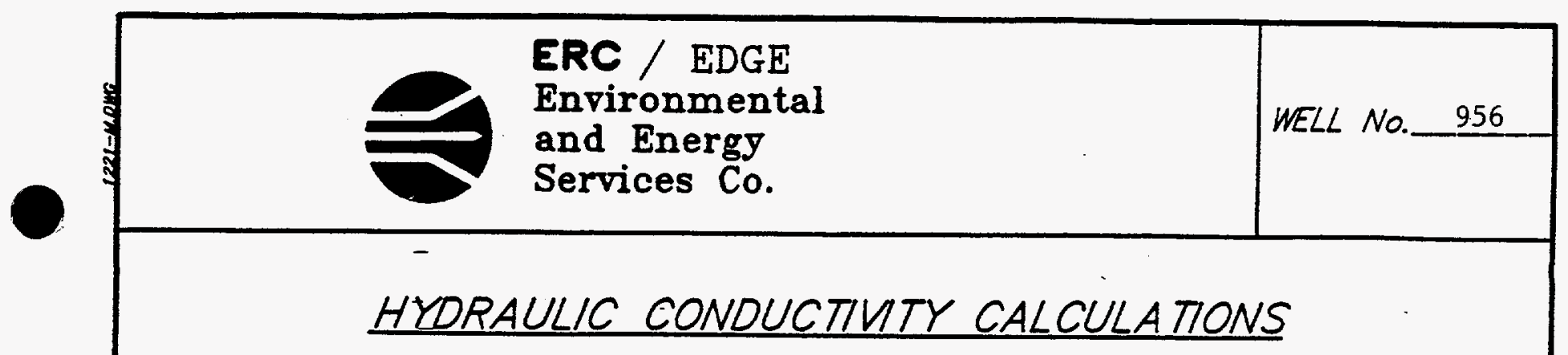

HO WAS COMPUTED FROM INTERCEPT OF PLOT OF LOG(H) VS. TIME SUCCESSIVE COMPUTED

VALUES FOR HO

(FEET)
1.0365
1.1687
1.3177
1.4718
1.7833
2.1866
2.5997
3.2586
3.7559
4.1242
4.2089

$\begin{array}{ccc}\text { TIME } & \text { DEPTH TO WATER } & \begin{array}{r}\text { HEAD } \\ \text { (SEC }\end{array} \\ \text { (FEET) } \\ 10.00 & 4.330 & 3.330 \\ 20.00 & 3.430 & 2.430 \\ 30.00 & 2.780 & 1.780 \\ 40.00 & 2.310 & 1.310 \\ 50.00 & 1.930 & .930 \\ 60.00 & 1.640 & .640 \\ 75.00 & 1.450 & .450 \\ 90.00 & 1.300 & .300 \\ 105.00 & 1.220 & .220 \\ 120.00 & 1.140 & .140 \\ 150.00 & 1.090 & .090 \\ 180.00 & 1.070 & .070 \\ 240.00 & 1.040 & .040 \\ 300.00 & 1.020 & .020 \\ 360.00 & 1.020 & .020 \\ 420.00 & 1.020 & -.020 \\ 480.00 & 1.010 & .010 \\ 540.00 & 1.010 & .010 \\ 600.00 & 1.010 & .010\end{array}$




\section{HYDRAULIC CONDUCTIVTY CALCULATIONS}

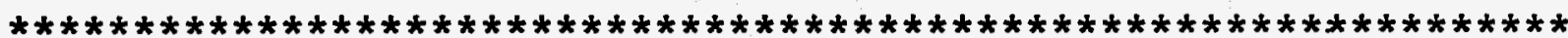

METHOD OF BOUWER AND RICE

COMPUTED RESULTS USING DIAMETER OF DRILLED HOLE:

PERMEABILITY $=2.98 \mathrm{E}-05 \mathrm{FT} / \mathrm{SEC}=9.08 \mathrm{E}-04 \mathrm{CM} / \mathrm{SEC}$

TRANSMISSIVITY $=2.98 \mathrm{E}-04 \mathrm{FT} * * 2 / \mathrm{SEC}$

COMPUTED RESULTS USING DIAMETER OF CASING AND SCREEN:

PERMEABIIITY $=4.17 \mathrm{E}-05 \mathrm{FT} / \mathrm{SEC}=1.27 \mathrm{E}-03 \mathrm{CM} / \mathrm{SEC}$

TRANSMISSIVITY $=4.17 \mathrm{E}-04 \mathrm{FT} * * 2 / \mathrm{SEC}$ 
CHANGE IN WATER LEVEL IN FEET

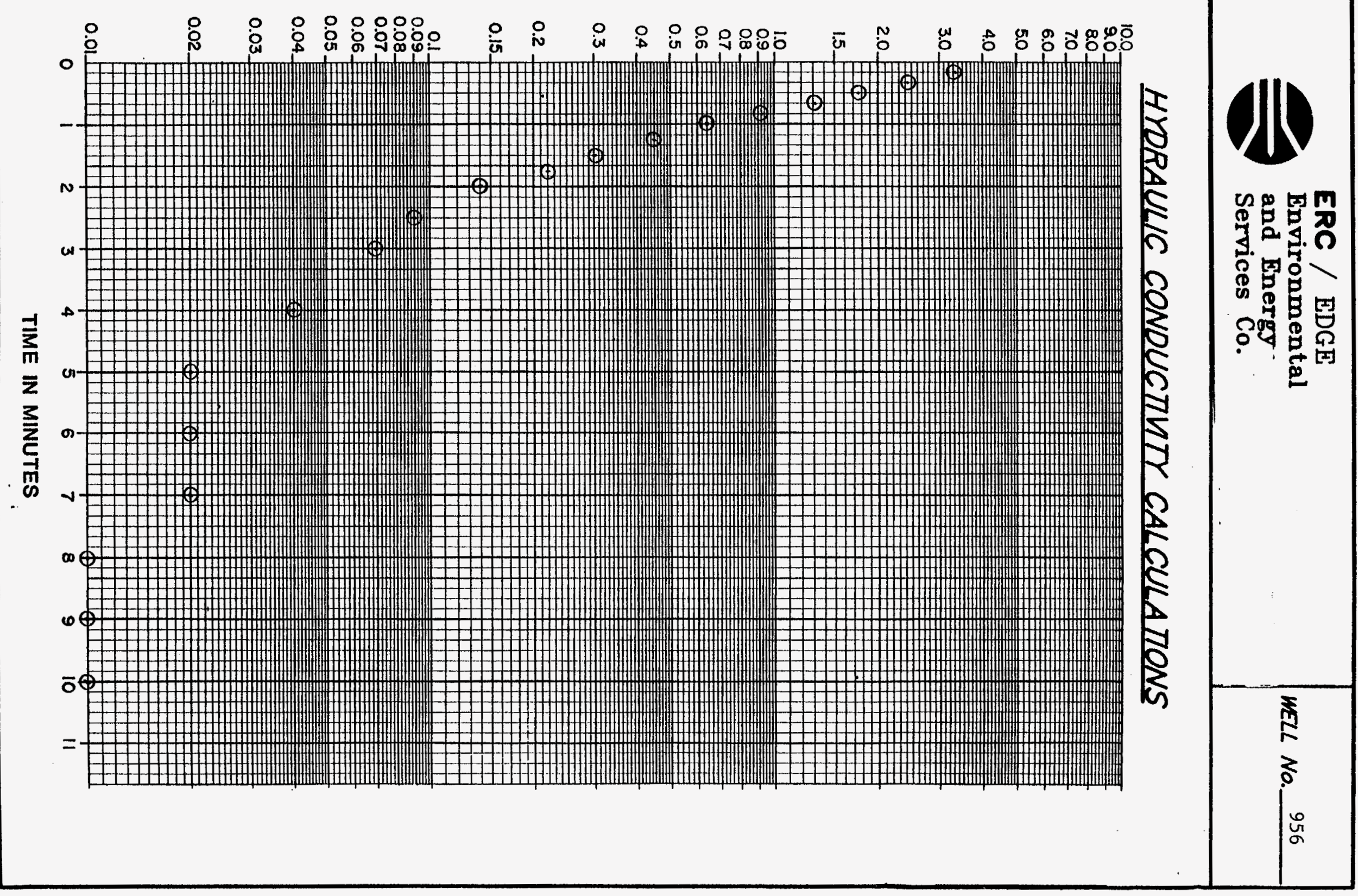




\subsection{General Information}

\section{1 mell Location}

Monitoring well number 957 is located in WAG 4. It is located approximately 1400 feet southwest of the intersection of Melton Valley Drive and Lagoon Road. The location is shown on ORNL drawing number C3E20004A075 Survey coordinates for this well are $N 18,908.9269$, E $28,861.0044(\mathrm{X}-10 \mathrm{grid})$ or latitude $35^{\circ}-54^{\prime}-58.20^{\prime \prime}$ and longitude $84^{\circ}-19^{\prime}-01.79^{\prime \prime}$. Coordinate data were provided by Martin Marietta Energy Systems. The method used for conversion from $x-10$ grid to Tennessee-Lambert State Plane coordinates came from the publication "Tennessee valley Authority Data Services Branch and Mapping Services Branch, Oak Ridge, Tennessee, DOE Plant Control, November 6, 1985 , Field Book: ESS-3115, pp. 1-20." The latitude and longitude were calculated by Adams Craft Herz Walker Engineering, Inc., using methods from the U.S. Coast and Geodetic Survey Publication 62-4, "State Plane coordinates by Automatic Data Processing."

\subsection{Drilling Information}

Well number 957 was drilled by Geotek Engineering Company. An Ingersoll Rand T-4 rig was used to drill this boring for monitor well installation under operation of Larry Ledbetter with the assistance of Fred Dixon, Tom Doonan and Tracy Mitchell: Drilling commenced on $4 / 4 / 90$, and was finished on 4/9/90. Paragraph 2.4.1 includes a detailed discussion of the well installation and a well schematic is included on the well installation/completion form. A synopsis of the drilling activity follows. This 
information was typed directly from field notes and was edited only when necessary for clarification.

4/4/90: This location has been determined class III. Move rig to location and set up on 2 sheets of plastic. Split spoon samples taken from surface to refusal at 12.5 feet. Reamed hole using a 22-inch auger to 12.0 feet. Set 11.2 feet $15-$ inch decontaminated steel diverter casing and grouted it to surface with 3 sacks cement. (OVA $=<.05 \mathrm{ppm}, \mathrm{RAD}=$ not over background).

4/5/90: Drill from 12.0 to 30.0 feet using an 14-inch air rotary tricone bit into containment box. Set 29.0 feet of 10-inch decontaminated steel surface casing with bentonite seal. Grouted annular with 9.0 sacks cement downgrade location to class II.

4/6/90: Drill from 30.0 to 82.5 feet using an 8.0-inch air rotary tricone bit into containment box (OVA $=<.05 \mathrm{ppm}, \mathrm{RAD}$ = not over background).

4/9/90: Set 82.2 feet of stainless steel 4-inch screen and casing with bentonite seal and sandpack.

4/10/90: Grouted annulus with 11.0 sacks cement.

This well was logged by ERC Environmental and Energy Services Co. (ERC) hydrogeologist Timothy A. Lee. All well construction materials and supplies were from Martin Marietta Energy Systems approved batches.- The batch origin of individual items is shown on the included Monitoring Well Materials Certification form. 
ERC / EDGE

Environmental

and Enercy

Services Co.

2.0 Technical Information

\subsection{Decontamination Procedures}

The drilling rig, down hole tools, surface casing, stainless steel screen, stainless steel casing, centralizers, and stainless steel silt trap underwent the cleaning decontamination procedures outlined in the drilling specifications (Release specific Technical Directions for Regulatory Compliance Monitoring Wells Phase 1, Oak Ridge National Laboratory, Oak Ridge, W.O. K-4147, April 1987, pgs. 2-4). A checklist of the cleaned materials is included with this data package.

\subsection{Geology}

WAG 4 is located in Melton Valley which is in the valley and Ridge Physiographic Province of East Tennessee. WAG 4 is underlain by shale, siltstone, and limestone of the Middle to Upper Cambrian Conasauga Group. The Conasauga Group in the Oak Ridge area consists of six formations. They are, in ascending order, the Pumpkin Valley shale, Rutledge Limestone, Rogersville Shale, Maryville Limestone, Nolichucky shale and the Maynardville Limestone. The Pumpkin Valley Shale and Rutledge Limestone underlie WAG 4. strike in and near WAG 4 ranges from N $85^{\circ} \mathrm{E}$ to $\mathrm{N} 15^{\circ} \mathrm{E}$ and dip varies from $27^{\circ}$ to vertical. These variations in strike and dip indicate that the conasauga has been deformed in the locale of WAG 4 . 


\subsection{Sample collection}

A bulk density soil sample was collected from the split spoon sample interval from 11.8 to 12.0 feet. The sample was measured and weighed, and a bulk density of 1.98 grams $/ \mathrm{cm}^{3}$ was calculated. No samples were collected for chemical analysis.

\subsection{Installation and Development}

\subsubsection{Installation}

This was a Type $B$ well. A 22.0-inch diameter boring was augered from ground surface to 7.0 feet. A 15 1/4-inch diverter casing was installed from surface to 11.2 feet below ground surface and grouted in place. A 14.0-inch diameter boring was drilled from 4.0 feet to 30.0 feet with a 14.0-inch air rotary tricone roller bit. A 10.0-inch diameter string of decontaminated steel surface casing was installed from 0.0 feet to 29.0 feet, sealed with a $3.3-$ foot bentonite pellet layer from 25.7 feet to 29.0 feet, and tremie grouted in place. The surface casing minimizes potential cross contamination between the regolith and bedrock water bearing zones. After the surface casing was installed, the air rotary method was used to drill an 8inch diameter boring to a total depth of 82.5 feet. A 4inch diameter stainless steel screen with welded bottom cap was installed from 52.0 feet to 82.2 -feet. A 4-inch diameter stainless steel casing was installed from the top of the screen at 52.0 feet and extended 2.04 feet above ground surface. A sandpack was then tremied into the annular space from 82.2 feet up to 49.6 feet, with a 1.8foot bentonite pellet seal poured into the annular space 
above the sandpack from 47.8 to 49.6 feet. The annular space from the top of the bentonite seal to the surface was tremie grouted with a cement/bentonite slurry. A detailed schematic of the well is included on the well installation/ completion form.

\subsubsection{We1l Development}

Well number 957 was developed to remove drill cuttings, silt, and other fines. The monitoring well was developed using a Geoguard pump with an air compressor. All pumps were cleaned prior to use according to specified cleaning procedures (see Paragraph 2.1). The well was developed until a measured total of 1233 gallons of water had been evacuated and the clarity of the discharge water was approved by the company

representative. The final turbidity value measured at completion was $4.0 \mathrm{NTU}$ 's. A development form showing the exact method of development and other pertinent data is appended.

\subsubsection{Installation of Dedicated Honitoring Well Pump}

After the well was developed, a Geoguard Model No. 5614 dedicated monitoring well pump was installed on 10/9/90 at a depth of 80.0 feet below ground surface. These pumps are decontaminated at American sigma and are sent prepackaged. A copy of the pump certification is kept on file at ORNL.

\subsection{Hydraulic conductivity resting}

Well number 957 was tested for the determination of hydraulic conductivity of the aquifer in the vicinity of 
the well screen. This was accomplished by instantaneously adding a known quantity of water to the monitoring well and measuring the recovery of the water level over time. The changing water levels were measured using a Druck 15 psi pressure transducer and an Omnidata Datapod II data recorder. The hydraulic conductivity value of $3.54 \times 10^{-6}$ $\mathrm{cm} / \mathrm{second}$ (shown as permeability on the hydraulic conductivity calculations printout attached) was calculated using the Bouwer and Rice method. A computer printout of the hydraulic conductivity calculations is included in this data package. 
ERC / EDGE

Environmental

and Energy

WELL No. 957

Services Co.

\section{PRE-DRILLING CHECKLIST FOR MONITORING WELLS}

PRE-DRILLING TASKS

1. EXCAVATION PERMIT OBTAINED.

\begin{tabular}{|c|c|}
\hline \multicolumn{2}{|c|}{ COMPLIANCE } \\
\hline$D A T E$ & $\| N \mid \pi A L S$ \\
\hline $4 / 4 / 90$ & \\
\hline $4 / 4 / 90$ & \\
\hline $\mathrm{N} / \mathrm{A}$ & $\mathrm{N} / \mathrm{A}$ \\
\hline
\end{tabular}

3o. SCREEN AND CASINGS HAVE BEEN WASHED, STEAMED, RINSED WTH DE-IONIZED OP DISTILED WATER. RINSED WTH ISOPROPV ALCOHOL WPAPPED WTH PROTECTVE COVERING AND STORED OFF THE GROUND.

36. PRE-PACKAGED SCREENS, CASINGS AND CENTRALIZERS WERE USED.

\begin{tabular}{|c|c|}
\hline \\
\hline \multicolumn{2}{|l|}{$4 / 9 / 90$} \\
\hline \multicolumn{2}{|l|}{$4 / 4 / 90$} \\
\hline $4 / 4 / 90$ & 10 \\
\hline
\end{tabular}

6. PO YETHRENE COVER IN PLACE OVER HOLE.

$4 / 4 / 90 \quad 102$

AOOITONAL NOTES/OBSERVA TONS:

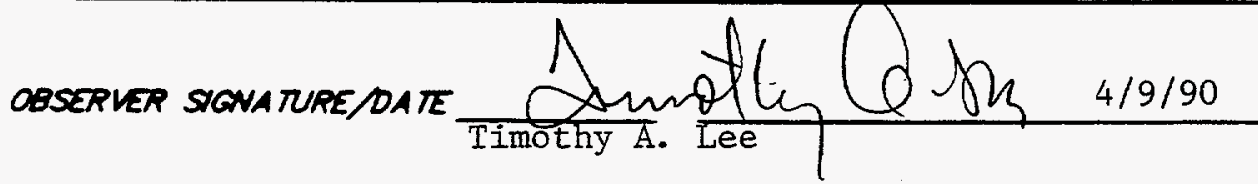


ERC / EDGE

Environmental

and Energy

WELL NO._957

Services Co.

DECONTAMINATION CHECKLIST

DRILLING EQUIPMENT

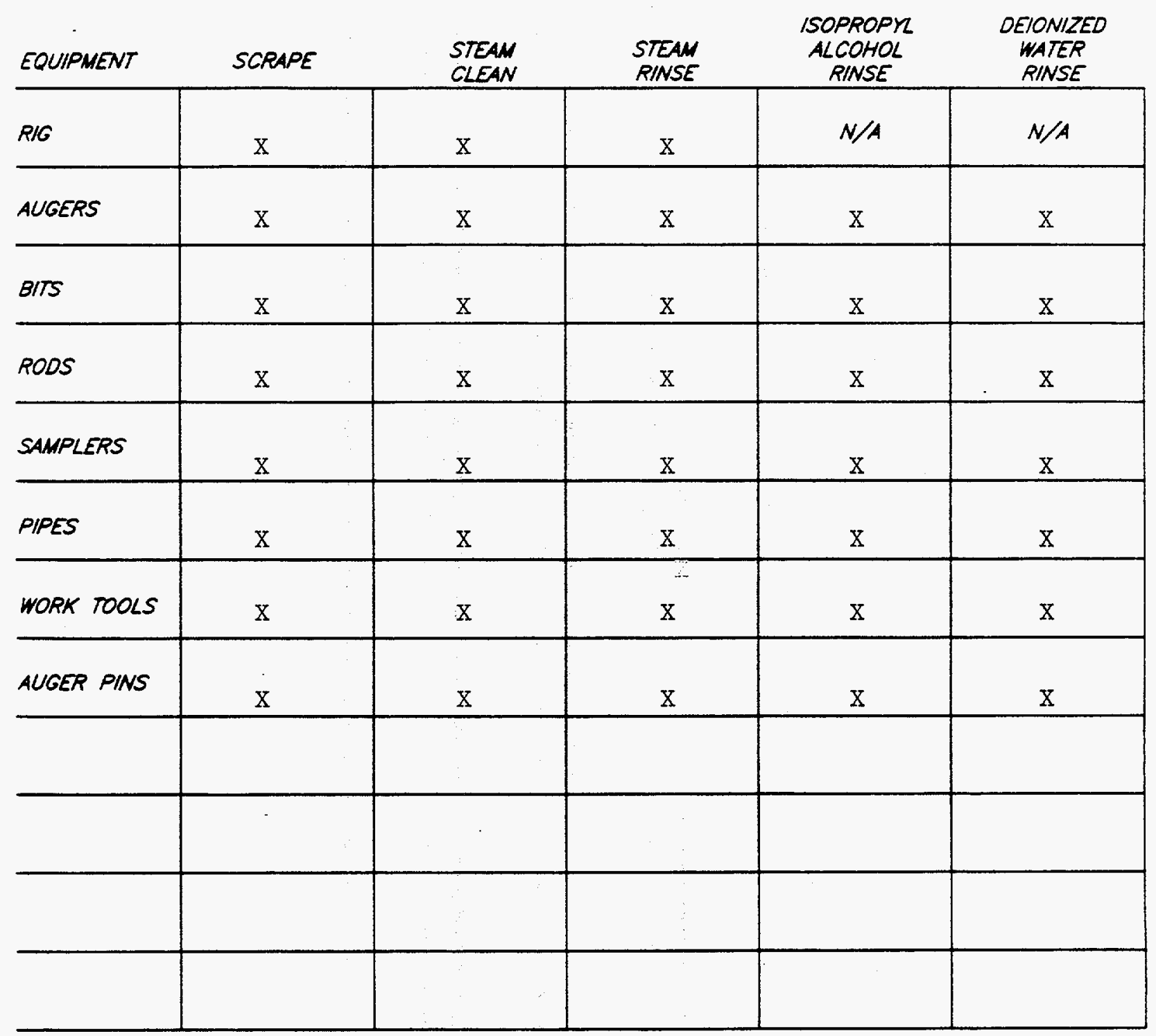

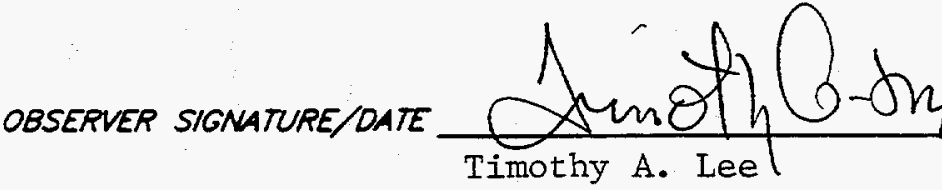

$4 / 9 / 90$

PAGE _ 8 OF 21 


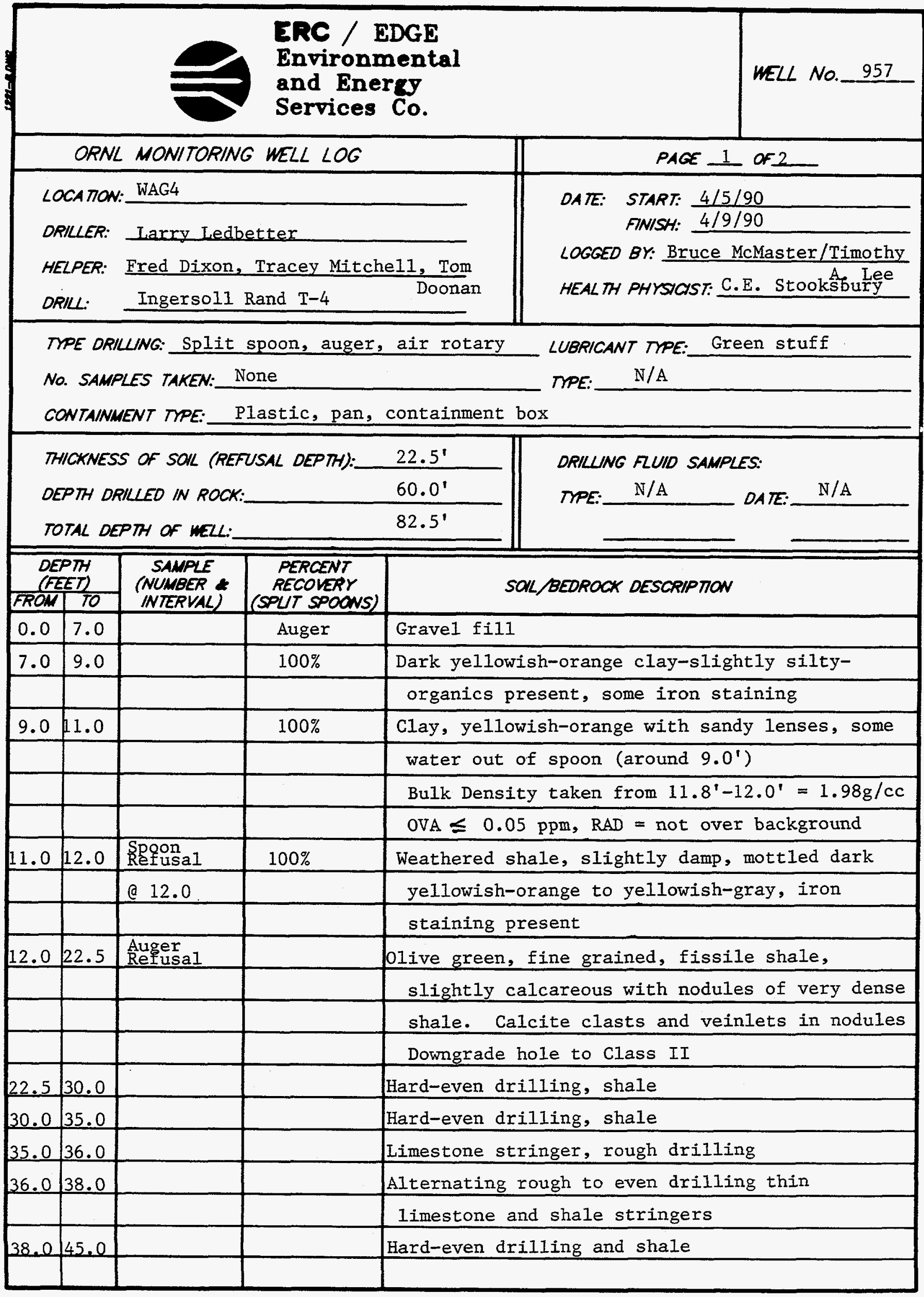




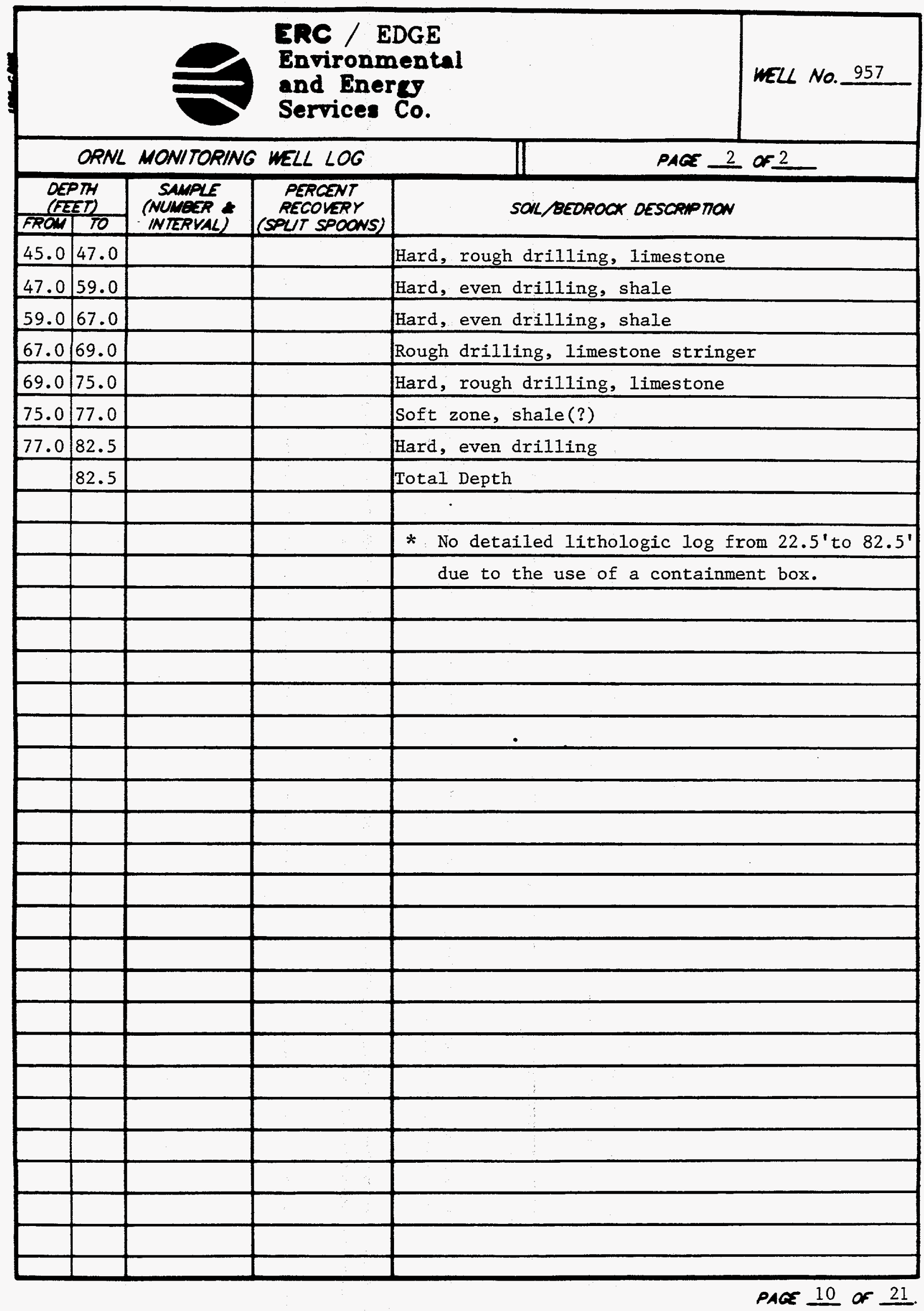




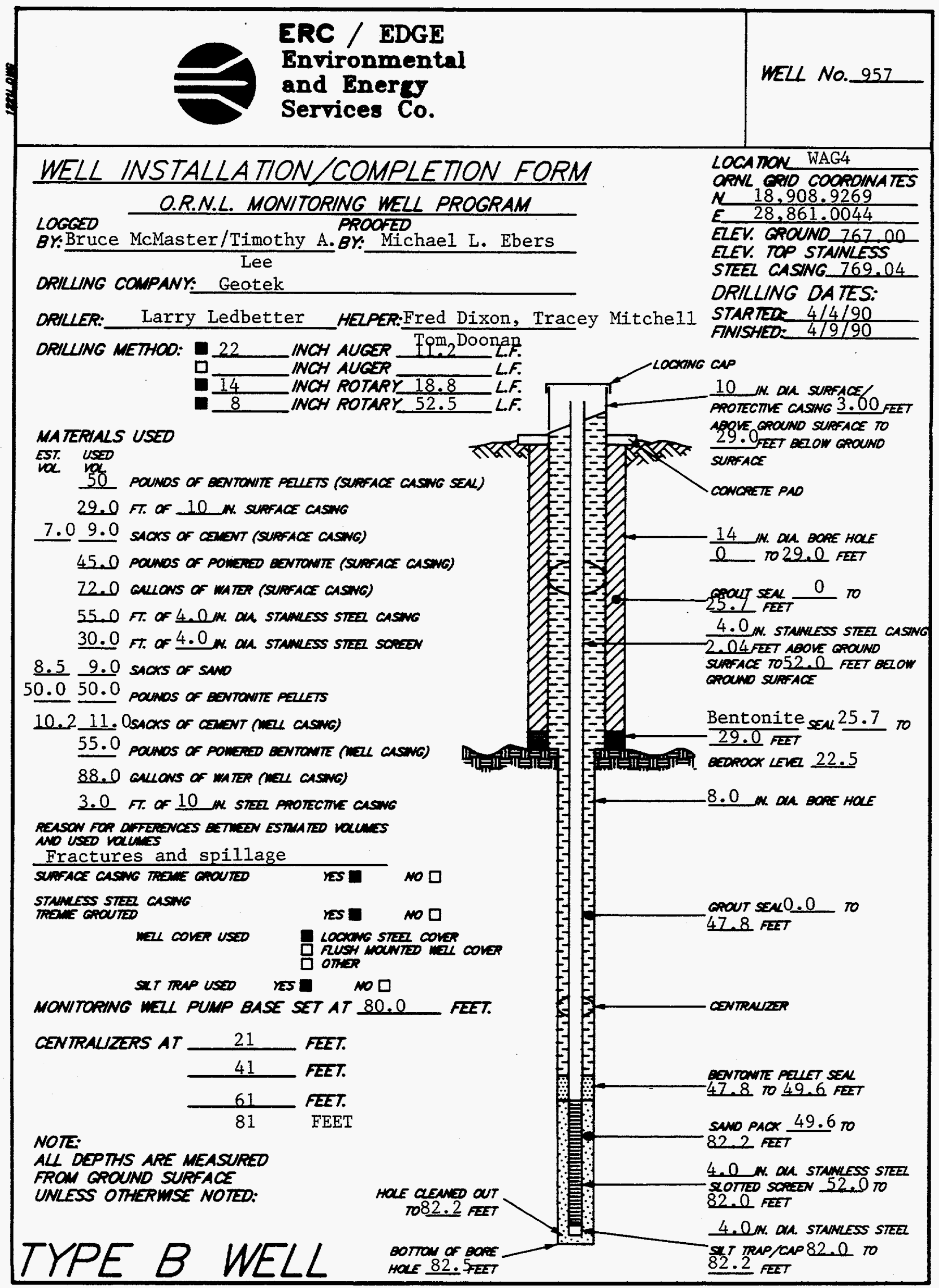

PACE 11 of 21 
ERC / EDGE

Environmental

WELL No. 957

and Energy

Services Co.

DATE: $4 / 9 / 90$

\section{MONITORING WELL MATERIALS \\ CERTIFICA TION}

ITEM/MATERIAL

SAND

BENTONITE

STAINLESS STEEL SCREEN

STAINLESS STEEL CASING

STAINLESS STEEL CENTRALIZERS

STAINLESS STEEL CAPS

MONITORING WELL PUMP

GROUT

WELL COVERS

SURFACE CASING

\begin{tabular}{|c|c|c|}
\hline & DATE USED & BATCH NUMBER \\
\hline & $4 / 9 / 90$ & 2 \\
\hline Powder & $4 / 10 / 90$ & 6 \\
\hline & $4 / 9 / 90$ & 1 \\
\hline CKAGED $\left.\quad \begin{array}{cc}\text { YES } \\
\text { NO }\end{array}\right)$ & $4 / 9 / 90$ & 3 \\
\hline CKAGED $\left(\begin{array}{c}\text { YES } \\
\text { NO }\end{array}\right)$ & $4 / 9 / 90$ & 3 \\
\hline CKAGED $\left.\begin{array}{c}\text { YES } \\
\text { NO }\end{array}\right)$ & $4 / 9 / 90$ & 3 \\
\hline CKAGED (2 $\left.\begin{array}{c}\text { YES } \\
\text { NO }\end{array}\right)$ & $4 / 9 / 90$ & 3 \\
\hline CKAGED $\left(\begin{array}{c}\text { YES } \\
\text { NO }\end{array}\right)$ & $10 / 9 / 90$ & 8 \\
\hline surface casing & $4 / 5 / 90$ & 7 \\
\hline well casing & $4 / 10 / 90$ & 7 \\
\hline
\end{tabular}

(PREPACKAGED

(PREPACKAGED

(PREPACKAGED

(PREPACKAGED

(PREPACKAGED

$4 / 5 / 90$

4

COMMENTS:

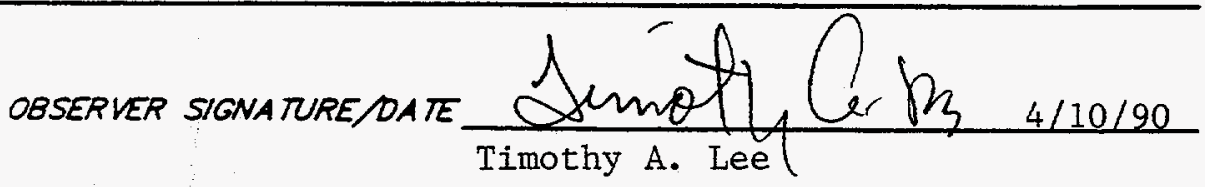




\section{POST-WELL COMPLETION \\ CHECKLIST}

\section{POST-MELL COMPLETION TASKS}

1. WU SCRAPED FROW AUGERS, SAMPLERS ANO ALL OTHER EQUIPMENT.

\section{COMPLIANCE \\ DA.TE INITALS}

2. ALL WUD FRON RIG AND EQUIPUENT SCRAPINGS ANO CUTTNOS DISPOSED OF IN ACCORDANCE WTH THE SPECAFCA IION" PROVOED.

3$$
\text { secariching }
$$

PRO DEVELOPED IN ACCORDANCE WTH THE SPECHFCA ION RECOROED.

4. DRKLNG STE PROPERLY CLEANED UP AFTER COMPLETON OF WIL INSTALA ION.

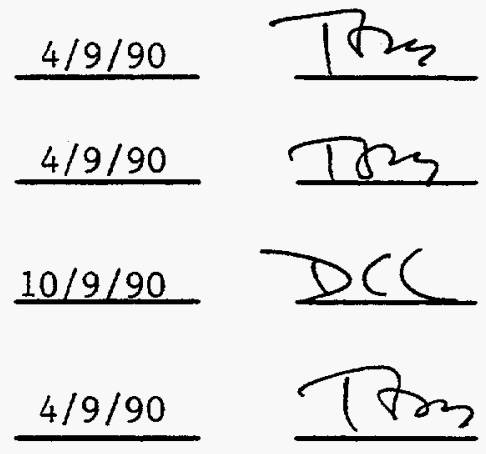

- REZEASE SPECATC TECAMGA DIRECTONS FOR REQULATORY COMPUANCE MONITORNG MEZLS PHASE I, OAK RTDEE NATIONAL LABORATOPY, OAK RIDCE M.O. K-4147, APAK 1987.

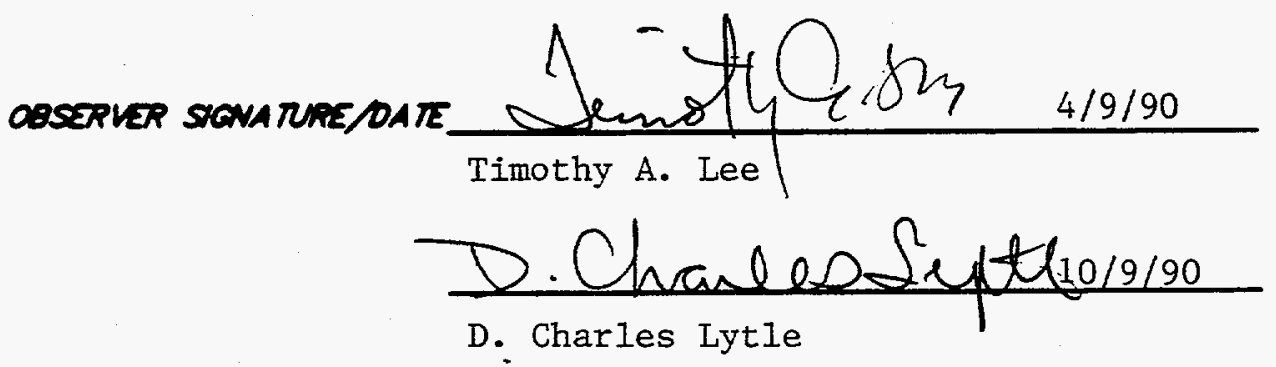




\section{MONITORING WELL \\ DEVELOPMENT FORM}

DEVELOPMENT DETA/LS

METHOD OF

QEVELQPMENT: Pumping and Geoguard pump

DEVELOPMENT

BEGAN DATE:

$8 / 13 / 90$ TME:

DEVELOPMENT

ENOING DATE:

$10 / 9 / 90$

OEVELOPMENT

OBSERVED BY: D. Charles Lytle

ONE WELL VOLUME: 75.5 GALLONS

TOTAL GALLONS PUMPED: 1233 TOTAL WELL VOLUMES PUMPED: 16.3

INITAL PH: 9.6 FNAL PH: 9.8

INITAL CONOUCTUTY ( $\mathrm{KS} / \mathrm{cm}): 837$ FINAL CONOUCTVTY $(\mu \mathrm{s} / \mathrm{cm}): 043$

OESCRIPTION OF INITAL TURBIDITY: ClOUdy

OESCRIPTION OF FNAL TURBIOITY:__ Clear

FNAL MEASURED TURBIDITY: 4.0 NTU'S

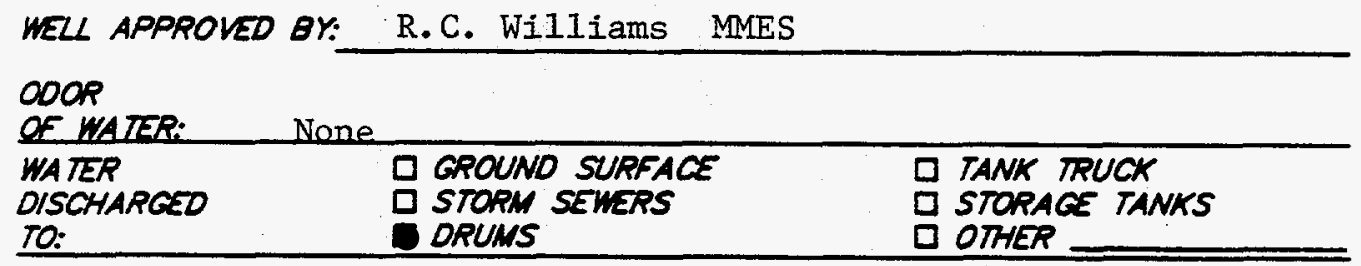

INITAL PRE-DEVELOPNENT

WATER DEPTH: 1.0 foot from ground surface

DEVELOPMENT OBSERVATIONS

OVA read anywhere from 100-1000 ppm. Vapors coming from well and barrels.

Breathing zone was fine.

OBSERVER SIGNATURE/OATE D fhavles Lyttlo/9/90 


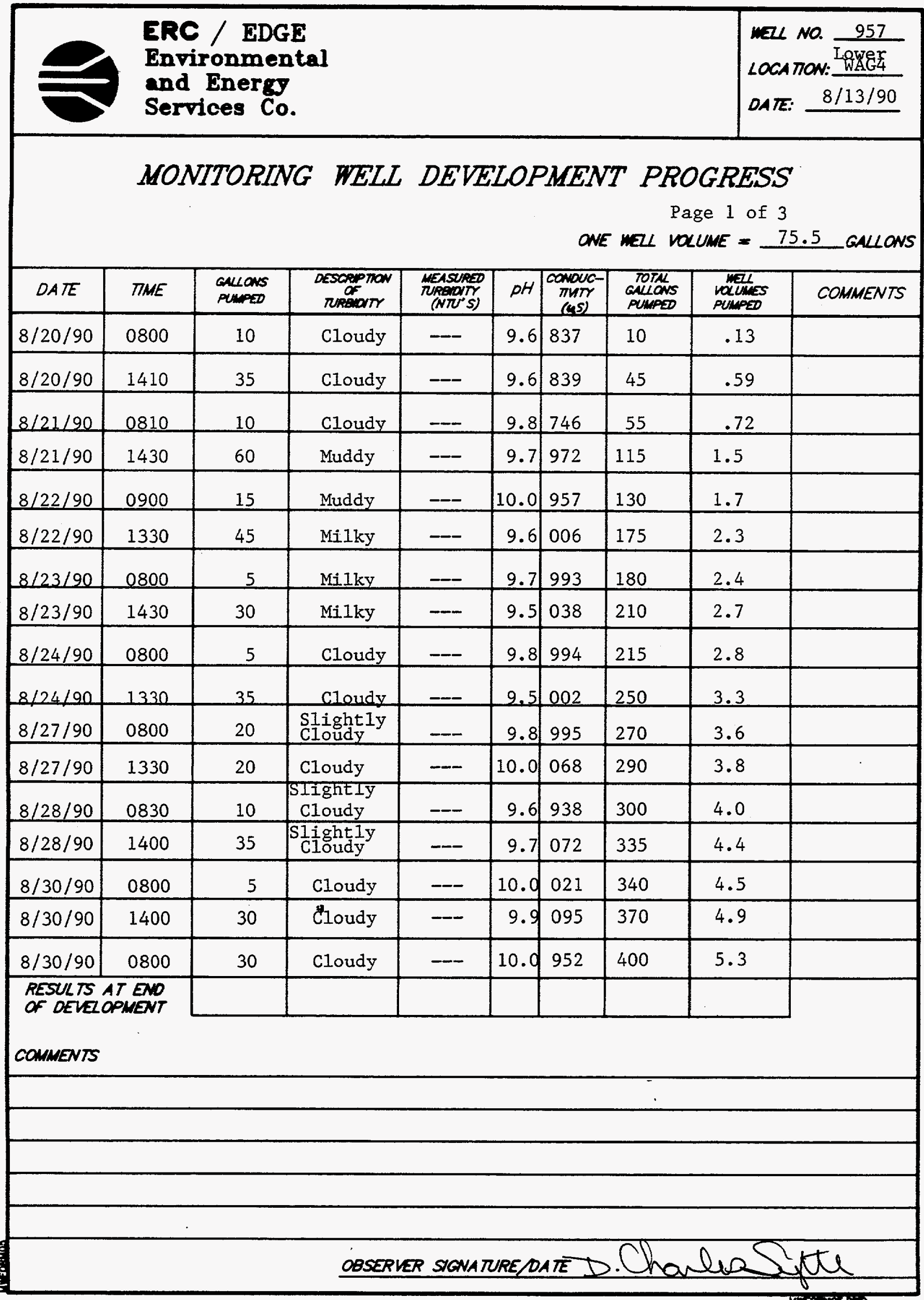




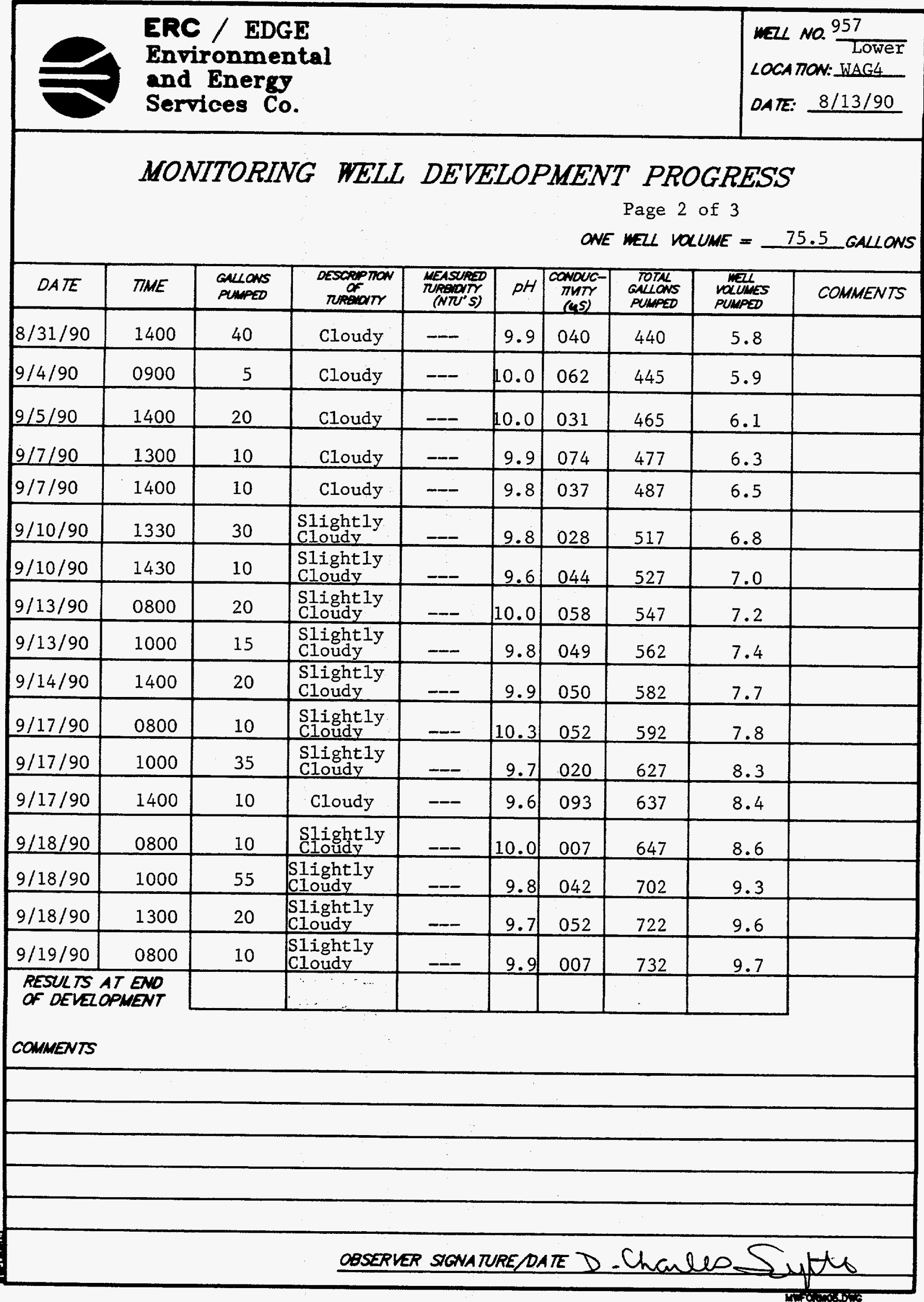

PAGE 16 of 21 . 
ERC / EDGE

Environmental

and Energy

Services Co.

mzL No. $\frac{957}{\text { Lower }}$

LOCA MON: WAG4

DATE: $8 / 13 / 90$

\section{MONITORING WELL DEVELOPMENT PROGRESS}

\begin{tabular}{|c|c|c|c|c|c|c|c|c|c|}
\hline & & & & & & & $E Z$ & $\begin{array}{l}\text { ge } 3 \circ \\
\text { UME }=\end{array}$ & $5 \quad$ GALLONS \\
\hline$D A T E$ & TME & $\begin{array}{l}\text { Gullows } \\
\text { Pumped }\end{array}$ & 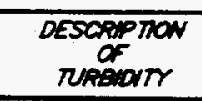 & $\begin{array}{l}\text { MEASUAED } \\
\text { RREWW } \\
\text { (NR'S) }\end{array}$ & $p H$ & $\begin{array}{c}\text { Convuc- } \\
\text { murr } \\
(\mathcal{L})\end{array}$ & $\begin{array}{l}\text { TOTAK } \\
\text { GNLOWS } \\
\text { PUINPED }\end{array}$ & 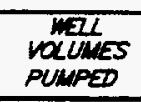 & COMMENTS \\
\hline $9 / 19 / 90$ & 1300 & 40 & $\begin{array}{l}\text { SIightly } \\
\text { Cloudy }\end{array}$ & -- & 9.7 & 036 & 772 & 10.2 & \\
\hline $9 / 19 / 90$ & 1400 & 10 & $\begin{array}{l}\text { Slightly } \\
\text { Cloudy }\end{array}$ & --- & 9.7 & 035 & 782 & 10.3 & \\
\hline $9 / 21 / 90$ & 0830 & 55 & $\begin{array}{l}\text { Slightly } \\
\text { Cloudy }\end{array}$ & -- & 10.1 & 995 & 837 & 11.1 & \\
\hline $9 / 24 / 90$ & 1300 & 10 & $\begin{array}{l}\text { Slightly } \\
\text { Cloudy }\end{array}$ & - & 10.1 & 054 & 847 & 11.2 & \\
\hline $9 / 24 / 90$ & 1400 & 20 & $\begin{array}{l}\text { Slightly } \\
\text { Cloudy }\end{array}$ & -- & 9.9 & 056 & 867 & 11.5 & \\
\hline $9 / 25 / 90$ & 1300 & 10 & $\begin{array}{l}\text { Slightly } \\
\text { Cloudy }\end{array}$ & --- & 9.7 & 038 & 877 & 11.6 & \\
\hline $9 / 26 / 90$ & 1000 & 85 & $\begin{array}{l}\text { Slightly } \\
\text { Cloudy }\end{array}$ & --- & 10.1 & 998 & 962 & 12.7 & \\
\hline $9 / 26 / 90$ & 1400 & 20 & $\begin{array}{l}\text { Slightly } \\
\text { Cloudy }\end{array}$ & -- & 9.7 & 079 & 082 & 13.0 & \\
\hline $9 / 27 / 90$ & 0800 & 20 & $\begin{array}{l}\text { Slight1y } \\
\text { Cloudy }\end{array}$ & -- & 9.8 & 027 & 1002 & 13.3 & \\
\hline $9 / 27 / 90$ & 1400 & 40 & $\begin{array}{l}\text { Slightly } \\
\text { Cloudy }\end{array}$ & -- & 9.9 & 114 & 1042 & 13.8 & \\
\hline $9 / 28 / 90$ & 0800 & 20 & $\begin{array}{l}\text { Slightly } \\
\text { cloudy }\end{array}$ & $\ldots$ & 9.8 & 048 & 1062 & 14.1 & \\
\hline $10 / 2 / 90$ & 0830 & 6 & $\begin{array}{l}\text { S1ightly } \\
\text { Cloudy }\end{array}$ & --- & 9.7 & 087 & 1068 & 14.1 & \\
\hline $10 / 2 / 90$ & 1100 & 20 & $\begin{array}{l}\text { Slightly } \\
\text { Cloudy }\end{array}$ & -- & 9.7 & 071 & 1088 & 14.4 & \\
\hline $10 / 2 / 90$ & 1400 & 20 & $\begin{array}{l}\text { Slightly } \\
\text { Cloudy }\end{array}$ & -- & 9.8 & 083 & 1108 & 14.7 & \\
\hline $10 / 4 / 90$ & 1300 & 20 & $\begin{array}{l}\text { Slightly } \\
\text { Cloudy }\end{array}$ & $\ldots$ & 9.9 & 040 & 1128 & 14.9 & \\
\hline $10 / 9 / 90$ & 0830 & 75 & $\begin{array}{l}\text { Slightly } \\
\text { Cloudy }\end{array}$ & -- & 9.8 & 034 & 1203 & 15.9 & \\
\hline $10 / 9 / 90$ & 1400 & 30 & Clear & 4.0 & 9.8 & 043 & 1233 & 16.3 & \\
\hline $\begin{array}{l}\text { RESULTS } \\
\text { OF DEVE }\end{array}$ & $\begin{array}{l}\text { END } \\
\text { UENT }\end{array}$ & & Clear & 4.0 & 9.8 & 043 & 1233 & 16.3 & \\
\hline
\end{tabular}

COMMENTS Excellent recharger and producer. Made plenty of water, water cleared and remained clear. Passed with $4.0 \mathrm{NTU}^{\prime} \mathrm{s}$. 


\section{HYDRAULIC CONDUCTIVTY CALCULATIONS}

PROGRAM SLUGT, VERSION 4.1, NOV. 1986

THIS PROGRAM CALCULATES MEAN TRANSMISSIVITIES FROM SLUG-TEST DATA BASED ON TWO ANALYTICAL APPROACHES:

(1) METHOD OF COOPER, BREDEHOEFT AND PAPADOPULOS, 1967

(ARTICLE IN VOL.3, NO.1 OF WRR ENTITLED

"RESPONSE OF A FINITE DIAMETER WELL TO AN INSTANTANEOUS CHARGE OF WATER")

(2) METHOD OF BOUWER AND RICE, 1976 (ARTICLE IN VOL. 12, NO.3 OF WRR ENTITLED

"A SLUG TEST FOR DETERMINING HYDRAULIC CONDUCTIVITY OF UNCONFINED AQUIFERS WITH COMPLETELY OR PARTIALLY PENETRATING WELIS")

WELL NO.: 957

DATE OF TEST: $10-17-90$

PROJECT NO.: E221-002

CLIENT: MMES

SITE LOCATION: WAG-4

EDGE, INC. FIELD INVESTIGATOR: JAMES W. CARUTHERS

INPUT DATA ARE:

INNER CASING DIAMETER $=4.00$ INCHES

INNER SCREEN OR OPEN-HOLE DIAMETER $=4.00$ INCHES

DIAMETER OF DRILLED HOLE $=8.00$ INCHES

LENGTH OF SCREEN OR INTAKE PORTION $=30.00$ FEET

DEPTH FROM STATIC LEVEL TO BOTTOM OF SCREEN $=80.40$ FEET

THICKNESS OF SATURATED AQUIFER ZONE $=30.00 \mathrm{FEET}$

DEPTH TO STATIC WATER LEVEI BELOW REF. POINT $=1.00$ FEET

ESTIMATED POROSITY OF GRAVEL PACK $=.20$

FALLING-HEAD INDEX = 1 ("1" IF FALIING, "O" IF RISING)

NUMBER OF DEPTH-TIME DATA POINTS = 32

HO WAS COMPUTED FROM INTERCEPT OF PLOT OF LOG(H) VS. TIME

SUCCESSIVE COMPUTED

VALUES FOR HO

(FEET)

1.4738

1.4745 


\section{HYDRAULIC CONDUCTIVTY CALCULATIONS}

\begin{tabular}{|c|c|c|}
\hline TIME & DEPTH TO WATER & HEAD \\
\hline (SEC & (FEET) & \\
\hline 10.00 & 2.530 & 1.530 \\
\hline 20.00 & 2.480 & 1.480 \\
\hline 30.00 & 2.510 & 1.510 \\
\hline 40.00 & 2.500 & 1.500 \\
\hline 50.00 & 2.460 & 1.460 \\
\hline 60.00 & 2.470 & 1.470 \\
\hline 75.00 & 2.470 & 1.470 \\
\hline 90.00 & 2.460 & 1.460 \\
\hline 105.00 & 2.450 & 1.450 \\
\hline 120.00 & 2.460 & 1.460 \\
\hline 150.00 & 2.460 & 1.460 \\
\hline 180.00 & 2.450 & 1.450 \\
\hline 240.00 & 2.450 & 1.450 \\
\hline 300.00 & 2.430 & 1.430 \\
\hline 360.00 & 2.430 & 1.430 \\
\hline 420.00 & 2.430 & 1.430 \\
\hline 480.00 & 2.430 & 1.430 \\
\hline 540.00 & 2.430 & 1.430 \\
\hline 600.00 & 2.400 & 1.400 \\
\hline 720.00 & 2.400 & 1.400 \\
\hline 840.00 & 2.390 & 1.390 \\
\hline 960.00 & 2.360 & 1.360 \\
\hline 1080.00 & 2.360 & 1.360 \\
\hline 1200.00 & 2.360 & 1.360 \\
\hline 1320.00 & 2.360 & 1.360 \\
\hline 1440.00 & 2.350 & 1.350 \\
\hline 1560.00 & 2.340 & 1.340 \\
\hline 1680.00 & 2.350 & 1.350 \\
\hline 1800.00 & 2.340 & 1.340 \\
\hline 1920.00 & 2.320 & 1.320 \\
\hline 2040.00 & 2.310 & 1.310 \\
\hline 2160.00 & 2.310 & 1.310 \\
\hline
\end{tabular}




\section{HYORAULIC CONDUCTIVTY CALCULATIONS}

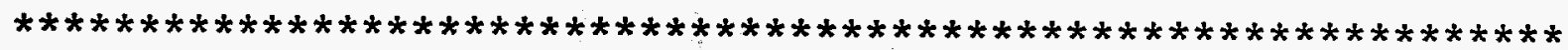

METHOD OF BOUWER AND RICE

COMPUTED RESULTS USING DIAMETER OF DRILLED HOLE:

$$
\text { PERMEABILITY }=1.16 \mathrm{E}-07 \mathrm{FT} / \mathrm{SEC}=3.54 \mathrm{E}-06 \mathrm{CM} / \mathrm{SEC}
$$

TRANSMISSIVITY $=3.48 \mathrm{E}-06 \mathrm{FT} * 2 / \mathrm{SEC}$

COMPUTED RESULTS USING DIAMETER OF CASING AND SCREEN:

$$
\text { PERMEABILITY }=1.33 \mathrm{E}-07 \mathrm{FT} / \mathrm{SEC} \quad=4.05 \mathrm{E}-06 \mathrm{CM} / \mathrm{SEC}
$$

TRANSMISSIVITY $=3.99 \mathrm{E}-06 \mathrm{FT} * * 2 / \mathrm{SEC}$ 


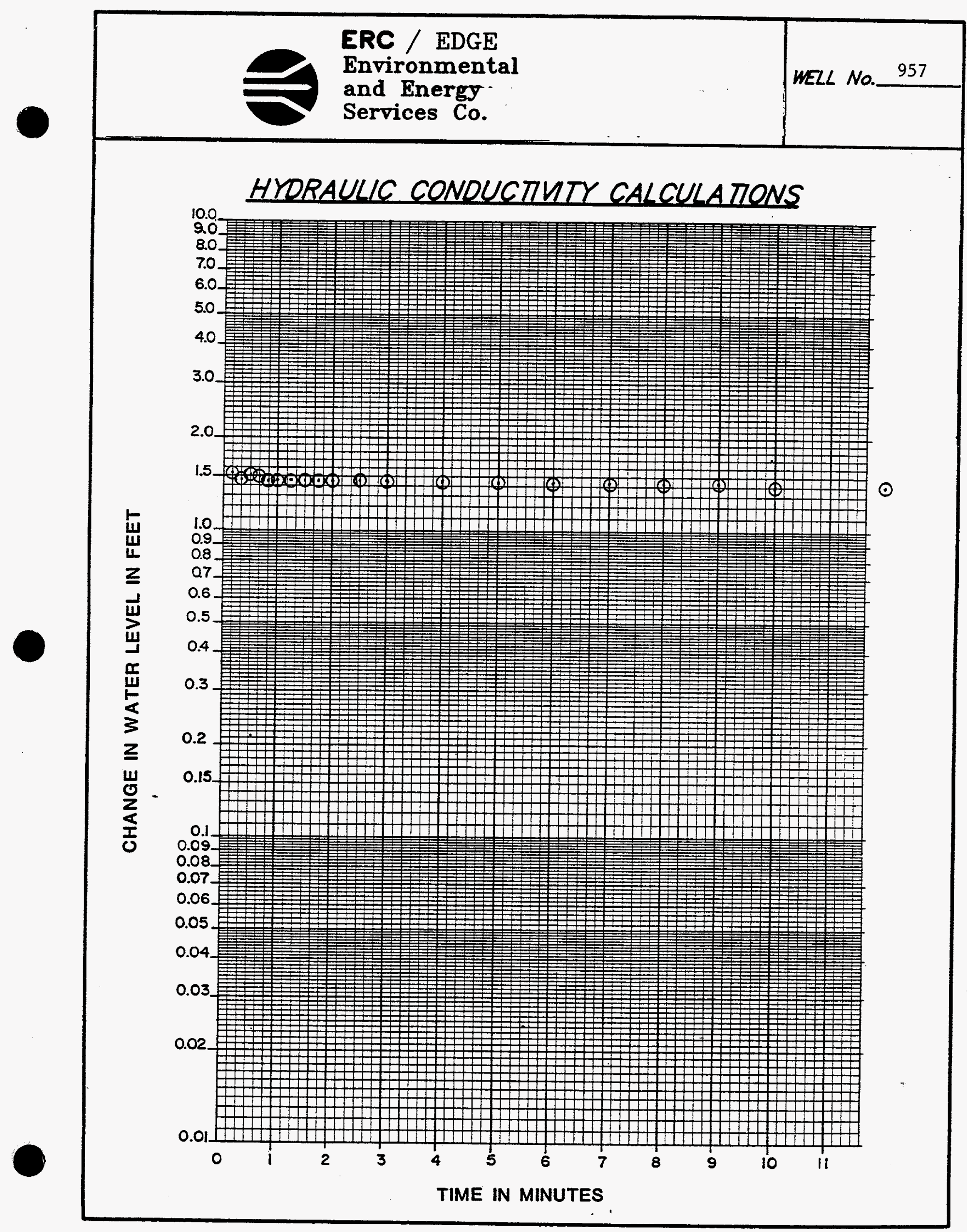

PACE 21 of 21 
1.0 General Information

\subsection{Well Iocation}

Monitoring well number 958 is located in WAG 4. It is located approximately 1400 feet southwest from the intersection of Melton Valley Drive and Lagoon Road. The location is shown on ORNL drawing number C3E20004A075. survey coordinates for this well are $N 18,900.3704, E$ $28,857.0538(\mathrm{X}-10 \mathrm{grid})$ or latitude $35^{\circ}-54^{\prime}-58.11^{\prime \prime}$ and longitude $84^{\circ}-19^{\prime}-01.77^{\prime \prime}$. Coordinate data were provided by Martin Marietta Energy Systems. The method used for conversion from $x-10$ grid to Tennessee-Lambert state Plane Coordinates came from the publication "Tennessee Valley Authority Data Services Branch and Mapping Services Branch, Oak Ridge, Tennessee, DOE Plant Control, November 6, 1985, Field Book: EsS-3115, pp. 1-20." The latitude and longitude were calculated by Adams Craft Herz Walker Engineering, Inc., using methods from the U.S. Coast and Geodetic Survey Publication 62-4, "State Plane Coordinates by Automatic Data Processing."

\subsection{Drilling Information}

Well number 958 was drilled by Geotek Engineering Company. An Ingersoll Rand T-4 rig was used to drill this boring for monitor well installation under operation of Larry Ledbetter with the assistance of Fred Dixon, Tom Doonan and Tracy Mitchell. Drilling commenced on $4 / 5 / 90$ and was finished on 4/9/90. Paragraph 2.4 .1 includes a detailed discussion of the well installation and a well schematic is included on the well installation/completion form. A synopsis of the drilling activity follows. This 
information was typed directly from field notes and was edited only when necessary for clarification.

4/5/90: The location was determined to be class III. The rig was moved to location and set up on two layers of plastic sheeting. Augered to 11.0 feet using a 14.0 inch auger. Set 11.0 feet of 10.0-inch decontaminated diverter casing and grouted with 7 sacks cement. (RAD $=<0.1 \mathrm{MR} / \mathrm{hr}$ and OVA $=<.05 \mathrm{ppm}$ ). The location was downgraded to class II.

4/9/90: Drill from 11.0 to 27.5 feet using an 8.0-inch air rotary tricone bit. Set 27.3 feet of 2 -inch stainless steel screen and casing with sandpack and bentonite seal.

4/10/90: Grout annulus with 4.0 sacks cement.

This well was logged by ERC Environmental and Energy services Co. (ERC) hydrogeologist Timothy A. Lee. AIl well construction materials and supplies were from Martin Marietta Energy systems approved batches. The batch origin of individual items is shown on the included Monitoring well Materials Certification form.

2.0 Technical Information

\subsection{Decontamination Procedures}

The drilling rig, down hole tools, surface casing, stainless steel screen, stainless steel casing, centralizers, and stainless steel silt trap underwent the cleaning decontamination procedures outlined in the arilling 
specifications (Release Specific Technical Directions for Regulatory Compliance Monitoring Wells Phase 1, Oak Ridge National Laboratory, Oak Ridge, W.0. K-4147, April 1987, pgs. 2-4). A checklist of the cleaned materials is included with this data package.

\subsection{Geology}

WAG 4 is located in Melton Valley which is in the valley and Ridge Physiographic Province of East Tennessee. WAG 4 is underlain by shale, siltstone, and limestone of the Middle to Upper Cambrian Conasauga Group. The Conasauga Group in the Oak Ridge area consists of six formations. They are, in ascending order, the Pumpkin Valley shale, Rutledge Limestone, Rogersville Shale, Maryville Limestone, Nolichucky shale and the Maynardville Limestone. The Pumpkin Valley Shale and Rutledge Limestone underlie WAG 4. strike in and near WAG 4 ranges from N $85^{\circ} \mathrm{E}$ to $\mathrm{N} 15^{\circ} \mathrm{E}$ and dip varies from $27^{\circ}$ to vertical. These variations in strike and dip indicate that the conasauga has been deformed in the locale of WAG 4.

\section{3 sample collection}

No samples were collected.

\subsection{Installation and Development}

\subsubsection{Installation}

This is a Type $\mathrm{D}$ wel1. A 14.0-inch diameter boring was augered from ground surface to 11.0 feet. The air rotary method was required to complete the boring to the specified 
total well depth. Therefore, 10.0-inch diverter casing was installed and grouted. An 8-inch diameter boring was then drilled with an air rotary tricone roller bit from 11.0 to 27.5 feet. A 2-inch diameter stainless steel screen with threaded bottom cap was installed from 12.1 to 27.3 feet. A 2-inch diameter stainless steel casing was installed above the screen at 12.1 feet and extended 2.9 feet above ground surface. A sandpack was then tremied into the annular space from 27.3 feet up to 11.0 feet, with a 1.5foot bentonite pellet seal poured into the annular space above the sandpack from 9.5 to 11.0 feet. The annular space from the top of the bentonite seal to the surface was tremie-grouted with a cement/bentonite slurry. A detail of the well is included on the well installation/completion form.

\subsubsection{Ne11 Development}

Well number 958 was developed to remove drill cuttings, silt, and other fines. The monitoring well was developed using a Geoguard pump with an air compressor. All pumps were cleaned prior to use according to specified cleaning procedures (see Paragraph 2.1). The well was developed until a measured total of 130 gallons of water had been evacuated and the clarity of the discharge water was approved by the company representative. The final turbidity value measured at completion was 1.0 NTU. A development form showing the exact method of development and other pertinent data is appended. 
2.4.3 Installation of Dedicated Konitoring Nell Pump

After the well was developed, a Geoguard Model No. 5614 dedicated monitoring well pump was installed on 8/21/90 at a depth of 26.1 feet below ground surface. These pumps are decontaminated at American Sigma and are sent prepackaged. A copy of the pump certification is kept on file at ORNL.

\subsection{Hydraulic conductivity Testing}

Well number 958 was tested for the determination of hydraulic conductivity of the aquifer in the vicinity of the well screen. This was accomplished by instantaneously adding a known quantity of water to the monitoring well and measuring the recovery of the water level over time. The changing water levels were measured using a Druck 15 psi pressure transducer and an Omnidata Datapod II data recorder. The hydraulic conductivity value of $2.42 \times 10^{-5}$ $\mathrm{cm} / \mathrm{second}$ (shown as permeability on the hydraulic conductivity calculations printout attached) was calculated using the Bouwer and Rice method. A computer printout of the hydraulic conductivity calculations is included in this data package. 


\section{ERC / EDGE}

Environmental

and Energy

Services Co.

WELL No. 958

\section{PRE-DRILLING CHECKLIST FOR MONITORING WELLS}

PRE-ORILLING TASKS

1. EXCAVATION PERMIT OBTAINED.

2. ALL EQUIPMENT HAS BEEN CLEANED BEFORE DRILLING.

3a. SCREEN AND CASINGS HAVE BEEN WASHED, STEAMED, RINSED WTH DE-IONIZED OR DISTLLED WATER, RINSED WTH ISOPROPI ALCOHOL WRAPPED WTH PROTECIVE COVERING AND STORED OFT THE GROUND.

36. PRE-PACKAGED SCREENS, CASINGS AND CENTRAUIEERS WERE USED.

4. WORK AREA FOR SAMPLE EXAMINATIN COVERED WTH CLEAN POL KETHRENE.

5. CLEAN KNIVES, GLOVES, SAMPLE JARS AND LABELS ON-HAND.

6. POL YETHIRENE COVER IN PLACE OVER HOLE.

AOOIMONAL NOTES/OBSERVATINS:

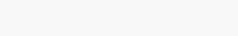

OVER HOLE.
COMPLIANCE

DATE INIMALS

4/5/90 TJ23

4/5/90 T23

N/A N/A

4/9/90 1/2n

4/9/90 Thy

$4 / 9 / 90+73$

4/9/90 T72

$4 / 9 / 90$

AODITONAL NOTES/OBSERATONS.

(19) 


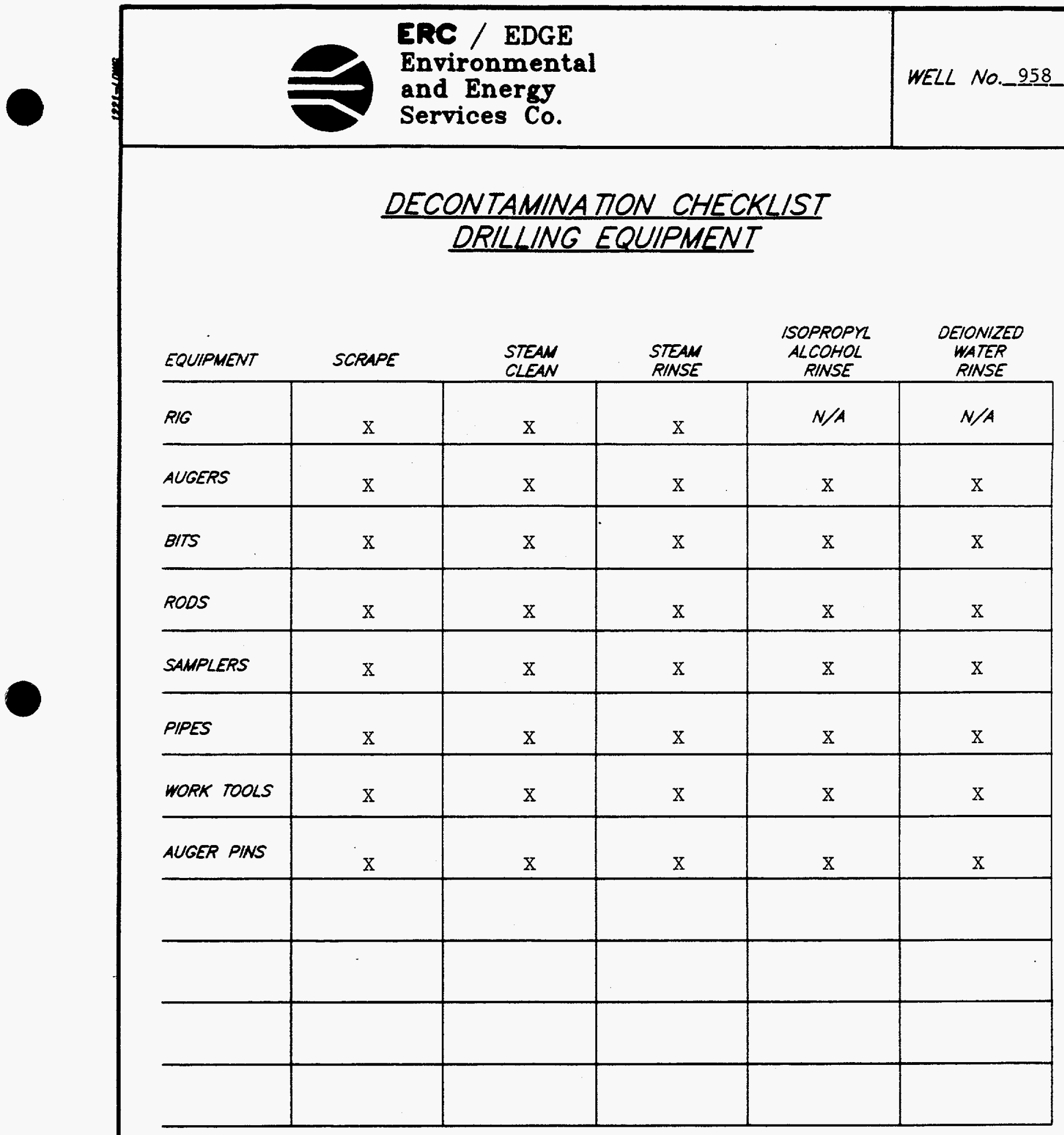

OBSERVER SIGNATURE/DATE $\frac{\text { Sumbete }}{\text { Timothy A. Lee }}$ (e.8M 4/16/90 
ERC / EDGE

Environmental

and Energy

WELL NO. 958

Services Co.

ORNL MONITORING WELL LOG
LOCAMON: WAG 4
ORILLER: $\frac{\text { Larry Ledbetter }}{\text { Fred Dixon, Tom Doonan, Tracey }}$
HELPER:
ORILL: $\quad$ Ingersol1 Rand T-4 Mitchell

TYPE DRILING: Auger, air rotary

PAGE 1 OF 1

DATE: START: $\quad 4 / 5 / 90$

FNISH: $4 / 9 / 90$

LOGGED BY: Timothy A. Lee

HEALTH PHYSICIST: C.E. Stooksbury

No. SAMPLES TAKEN:_ None

LUBRICANT THPE: Green stuff

CONTANMENT TPPE: Plastic, pan, containment box

THICKNESS OF SOIL (REFUSAL DEPTH): $12.0^{\prime}$

DEPTH DRILLED IN ROCK:

$15.5^{\prime}$

MPE: N/A

DATE: N/A

TOTAL DEPTH OF MELL:

$27.5^{\prime}$

\begin{tabular}{|c|c|c|c|c|}
\hline \multicolumn{2}{|c|}{$\begin{array}{c}\text { DEPTH } \\
\text { (FEET) }\end{array}$} & $\begin{array}{l}\text { SAMPLE } \\
\text { (NUMBER \& } \\
\text { INTERVAL) }\end{array}$ & $\begin{array}{c}\text { PERCENT } \\
\text { RECOVER Y } \\
\text { (SPUT SPOONS) }\end{array}$ & SOL/BEDROCK DESCRIPTION \\
\hline 0.0 & 7.0 & & Auger & Gravel fill \\
\hline 7.0 & 11.0 & & Auger & Clay, yellowish orange, sandy, wet c 9.0 feet. \\
\hline & & & & (OVA $=<0.05 \mathrm{ppm}, \mathrm{RAD}=$ not over background) \\
\hline 11.0 & 22.5 & & Air Rotary & *Limestone and shale, hard \\
\hline 22.5 & 27.5 & & Air Rotary & *Shaley limestone, soft \\
\hline & 27.5 & & 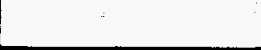 & Total Depth \\
\hline & & & & Downgrade to Class II \\
\hline & & & & * No detailed lithologic description \\
\hline & & & & available from 11.0 to 27.5 feet due to \\
\hline & & & & use of a containment box. \\
\hline & & & & \\
\hline & & & & \\
\hline & & & & \\
\hline & & & & \\
\hline & & & & \\
\hline & & & & \\
\hline & & & & \\
\hline & & & & \\
\hline & & & & \\
\hline & & & & \\
\hline
\end{tabular}


ERC / EDGE

Environmental

WELL NO. 958

and Energy

Services Co.

WELL INSTALLATION/COMPLETION FORM

LOGGED

BY: Timothy A. Lee

O.R.N.L. MONITORING WELL PROGRAM

PROOFED

BY: Michael I. Ehers

DRILUNG COMPANY: Geotek

ORIUER: Larry Ledbetter

HELPER: Fred Dixon, Tom Doonan Tracey Mitche11

EQUIPMENT

a 14.0 INCH AUGER 11.0 L.F.
INCH AUGER L.F.
$\square \quad 8.0$ INCH ROTARY 16.5 L.F.

MATERIALS USEO

EST. USED

VOL. VOL.

15.0 FEET of 2.0 IN. S.S. SCREEN

15.0 FEET OF 2.0 IN. S.S. CASING

4.1 5.5 SACKS OF SAND

50.050 .0 POUNDS OF BENTONITE PELLETS

2.34 .0 SACKS OF CEMENT

20.0 POUNDS OF POWOERED BENTONITE

32.0 GALLONS OF WATER (CEMENTING)

REASON FOR DIFFERENCES BETWEEN ESTMATED VOLUMES AND USED VOLUMES

Fractures, irregular boring diameters

and spillage

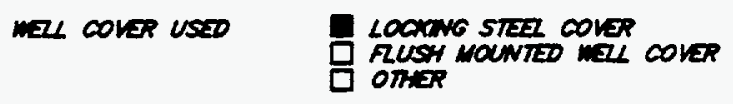

SRT TRA USED RESE NOL

MONITORING WEZL PUMP BASE SET AT 26.1 FEET.

$$
\begin{array}{r}
\text { CENTRALIZERS AT } \frac{8.0}{26.0} \text { FEET. } \\
\text { FEET. } \\
\text { FEET. }
\end{array}
$$

NOTE:

ALL DEPTHS ARE MEASURED

FRON GROUND SURFACE

UNLESS OTHERWSE NOTED:

TYPE D WELL
HOF CENED our

T0 27.3 FET

Botrow of banghoce 27.5 FET
LOCATON WAG4

ORNL GRID COORDINATES

$N \quad 18,900.3704$

E $28,857.0538$

ELEV. GROUND 767_03

ELEV. TOP STAINLESS

STEEL CASING 769.03

DRILLING DATES:

STARTED: $4 / 5 / 90$

FNISHED: $4 / 9 / 90$

LOCKING STEER COVER

8 NOH OIAMETER STER PROTECTIE CASANG 3.03 RT. ABOVE GROUND TO 2.0 FT. BEZOW GROUNO SURFACE

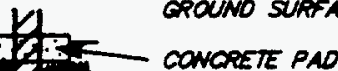

10.0 NWCH OIVERTER CASING 0.0 FT. ABOVE GPOUNO SURFACE TO 11.0 FT. BZOW GPOUND SURFACE

- 14.0INOH BOREHOLE 0.0 Td. 1.0 FEE

GROUT SEN 0.0 TO

9.5 FEI

8.0 NNOH OIAWETER BOREFALE

2.0 NOH OAMETER STAINESSS STER CASNG 2.0 NT. ABOVE GRONNO SUREACE TO 12.1FT. BLOW GROUNO SURFACE

CENTRALER (TMP.)

EDNTONIE PELET SEN 9.5 To 11.0 FEET

SANO PACK

11.0 7027.3 _EET

2.0 NOH OAMETER stankess ster 0.010

SCOTLD SCREDN

12.1 ro 27.1 FEET

2.0 NOH DUMETER STANLESS STER SKT TRAP/CAP

27.1 TO 27.3 FET

NOT TO SCALE 


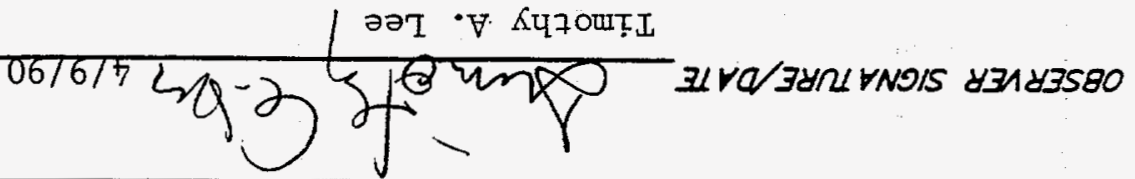

SINZWWOD

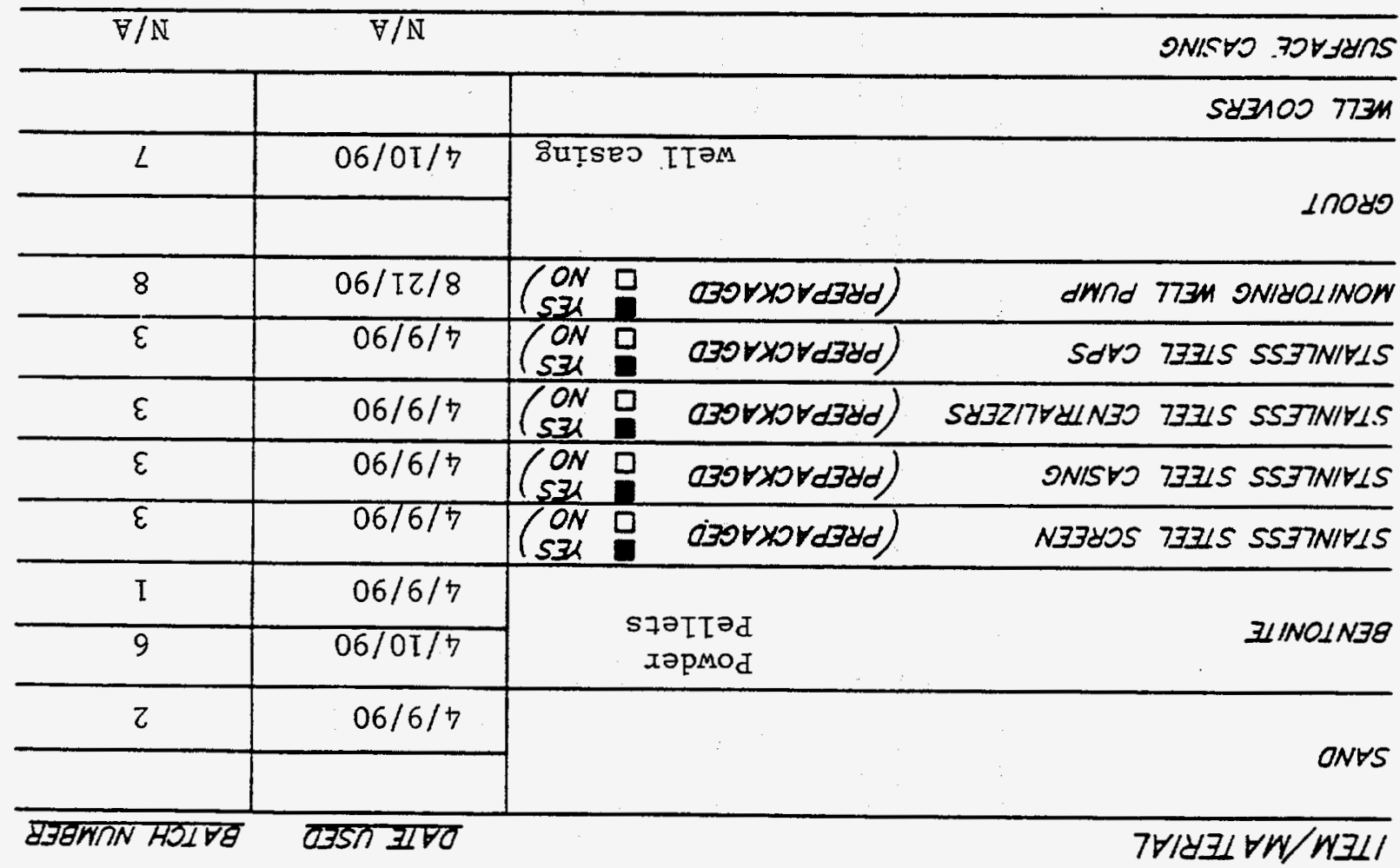

\section{NOL $\forall J / 11+730$ \\ ST甘IBבIVW 773M INIHOIINOW}

$06 / 6 / 7: ㅋ 11 \forall 0$

$856 \circ 0 \mathrm{~N} 773 \mathrm{~m}$
- O5 saotaxas

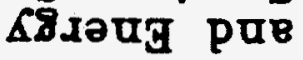

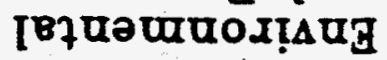

ВDवस / 2yב 


\section{POST-MELL COMPLETION \\ CHECKLIST}

\section{POST-WELL COMPLETION TASKS}

\section{COMPLIANCE
OA.E}

1. WUD SCRAPED FROW AUGERS SAMPLERS, ANO ALU

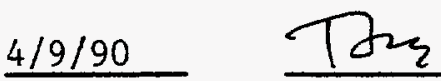
OTHER EQUIPMENT. CUTINOS DISPOSED OF IN ACCORDANCE WTH THE SPECAFCA NON " PROWDED.

3. MELL OELELOAED IN ACCOROANCE WITH THE SPECAFTCA DON

$8 / 21 / 90$

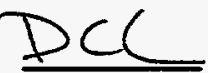
PROVDED ANO DETAKS OF THE DELEZOPWENT ACTUTY RECORDED.

4. ORKLNG STE PROPERLY QLEANED UP AFTER COMPLETION OF MEL INSTALLATON.

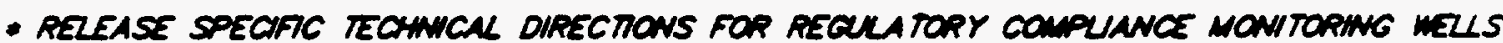
PHASE I. OAK RIOCE NATONAL LABORATOPY, OAK AMDCE W. K-4147, APRR 1987.
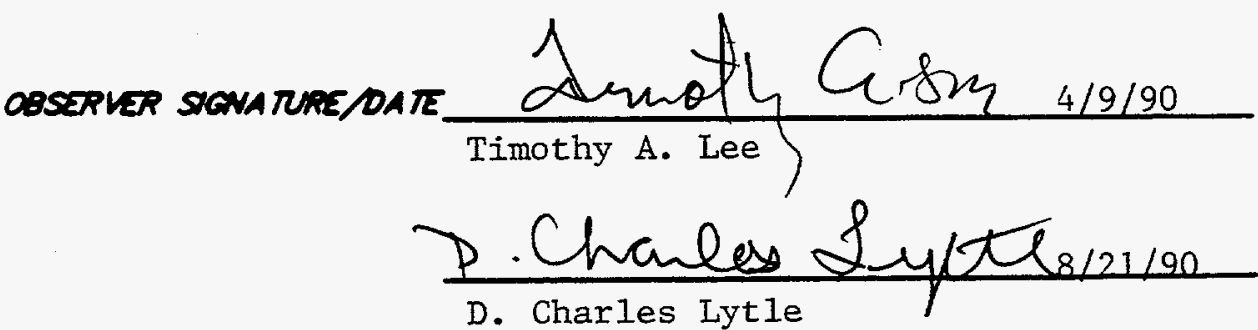


\section{MONITORING WELL \\ DEVELOPMENT FORM}

DEVELOPMENT DETAILS

METHOD OF

DEVELOPMENT: Pumping with Geoguard pump

OEVELOPMENT

BEGAN DATE:

$8 / 20 / 90$

TME:

DEVELOPMENT

ENOING OATE:

$8 / 21 / 90$

DEVELOPMENT

OBSERVED BY:

D. Charles Lytle

ONE WELL VOLUME: 10.2 GALLONS

TOTAL GALLONS PUMPED: 130 TOTAL WELL VOLUMES PUMPED: 12.7

NITAL OH: 9.9 FNAL PH: 8.9

INITAL CONDUCTUTY (K S/ cm): 849

FNAL CONOUCTVTY ( $H S / \mathrm{Cm}): 948$

OESCRIPTION OF INITAL TURBIOITY: MuddY

DESCRIPTION OF FNAL TURBIDITY:

Clear

FNAL MEASURED TURBIDIT: $1.0 \mathrm{NTU}^{\prime} \mathrm{S}$

WELL APPROVED BY: R.C. Williams MMES

$\begin{array}{lll}\text { ODOR } & & \\ \text { OE MATER: } & \text { NONE } & \\ \text { WATER } & \text { D GROUND SURFACE } & \text { D TANK TRUCK } \\ \text { DISCHARGED } & \text { STORM SEWERS } & \text { DTORAGE TANKS } \\ \text { TO: } & \text { DRUMS } & \text { D OTHER }\end{array}$

INITAL PRE-DEVELOPNENT

WATER DEPTH: $\quad 4.5$ feet from ground surface

\section{DEVELOPMENT OBSERVATIONS}

OBSERVER SIGNATURE/OATE D. Chaldedytt $/ 21 / 90$

D. Charles Lytle 
ERC / EDGE

Environmental

and Energy

Services Co.
mzL No. $\frac{958}{\text { Lower }}$ LOCA 70 : WAG4

DATE: $8 / 20 / 90$

\section{MONITORING WELL DEVELOPMENT PROGRESS}

\begin{tabular}{|c|c|c|c|c|c|c|c|c|c|}
\hline \multicolumn{10}{|c|}{ ONE WEL VOLUME $=10.2$ GALLONS } \\
\hline$D A T E$ & TIME & $\begin{array}{l}\text { QRECONS } \\
\text { PeMPED }\end{array}$ & 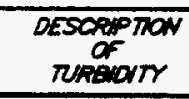 & $\begin{array}{l}\text { MEASURED } \\
\text { TURSONTS } \\
\text { (NN"S) }\end{array}$ & $p H$ & $\begin{array}{c}\text { CONOUC- } \\
\text { murY } \\
(4 S)\end{array}$ & $\begin{array}{l}\text { TOTRK } \\
\text { GNLOWS } \\
\text { PUAPED }\end{array}$ & $\begin{array}{l}\text { Mal1 } \\
\text { vo UuMES } \\
\text { PUMPED }\end{array}$ & COMMENTS \\
\hline $8 / 20 / 90$ & 0800 & 10 & Muddy & - & 9.9 & 849 & 10 & 1.0 & \\
\hline $8 / 20 / 90$ & 1410 & 30 & Cloudy & -- & 8.8 & 946 & 40 & 3.9 & \\
\hline $8 / 21 / 90$ & 0810 & 10 & Cloudy & --- & 9.0 & 866 & 50 & 4.9 & \\
\hline $8 / 21 / 90$ & 1430 & 80 & Clear & 1.0 & 8.9 & 948 & 130 & 12.7 & \\
\hline & & & & & & & & & \\
\hline & & & & & & & & & \\
\hline & & & & & & & & & \\
\hline & & & & & & & & & \\
\hline & & & & & & & & & \\
\hline & & & & & & & & & \\
\hline & & & & & & & & & \\
\hline & & & & & & & & & \\
\hline & & & & & & & & & \\
\hline & & & & & & & & & \\
\hline & & & & & & & & & \\
\hline & & & & & & & & & \\
\hline $\begin{array}{l}\text { RESULTS } \\
\text { OF DEVEL }\end{array}$ & EEND & & Clear & 1.0 & 8.9 & 948 & 130 & 12.7 & \\
\hline
\end{tabular}

COMMENTS Okay recharger and producer. Pumped more air than water. Water cleared

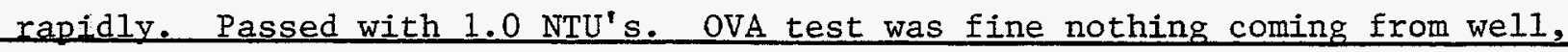
barrels. or breathing zone. 


\title{
HYDRAULIC CONDUCTIVTY CALCULATIONS
}

\author{
PROGRAM SLUGT, VERSION 4.1, NOV. 1986
}

THIS PROGRAM CALCULATES MEAN TRANSMISSIVITIES FROM

SLUG-TEST DATA BASED ON TWO ANALYTICAL APPROACHES:

(1) METHOD OF COOPER, BREDEHOEFT AND PAPADOPULOS, 1967 (ARTICLE IN VOL.3, NO.1 OF WRR ENTITLED

"RESPONSE OF A FINITE DIAMETER WELL TO AN INSTANTANEOUS CHARGE OF WATER")

(2) METHOD OF BOUWER AND RICE, 1976 (ARTICLE IN VOL. 12 , NO.3 OF WRR ENTITLED

"A SLUG TEST FOR DETERMINING HYDRAULIC CONDUCTIVITY

OF UNCONFINED AQUIFERS WITH COMPLETELY OR PARTIALLY PENETRATING WELLS")

WELL NO.: 958

PROJECT NO.: E221-002

SITE LOCATION: WAG-4

EDGE, INC. FIELD INVESTIGATOR: JAMES W. CARUTHERS
DATE OF TEST: $10-10-90$

CLIENT: MMES

\section{INPUT DATA ARE:}

INNER CASING DIAMETER $=2.00$ INCHES

INNER SCREEN OR OPEN-HOLE DIAMETER $=2.00$ INCHES

DIAMETER OF DRILLED HOLE $=8.00$ INCHES

LENGTH OF SCREEN OR INTAKE PORTION $=15.00$ FEET

DEPTH FROM STATIC LEVEL TO BOTTOM OF SCREEN $=22.90$ FEET

THICKNESS OF SATURATED AQUIFER ZONE $=15.00$ FEET

DEPTH TO STATIC WATER LEVEL BELOW REF. POINT $=1.00$ FEET

ESTIMATED POROSITY OF GRAVEL PACK $=.20$

FALLING-HEAD INDEX $=1$ ("I" IF FALIING, "O" IF RISING)

NUMBER OF DEPTH-TIME DATA POINTS = 32

HO WAS COMPUTED FROM INTERCEPT OF PLOT OF LOG(H) VS. TIME

$$
\begin{aligned}
& \text { SUCCESSIVE COMPUTED } \\
& \text { VALUES FOR HO }
\end{aligned}
$$

(FEET) 


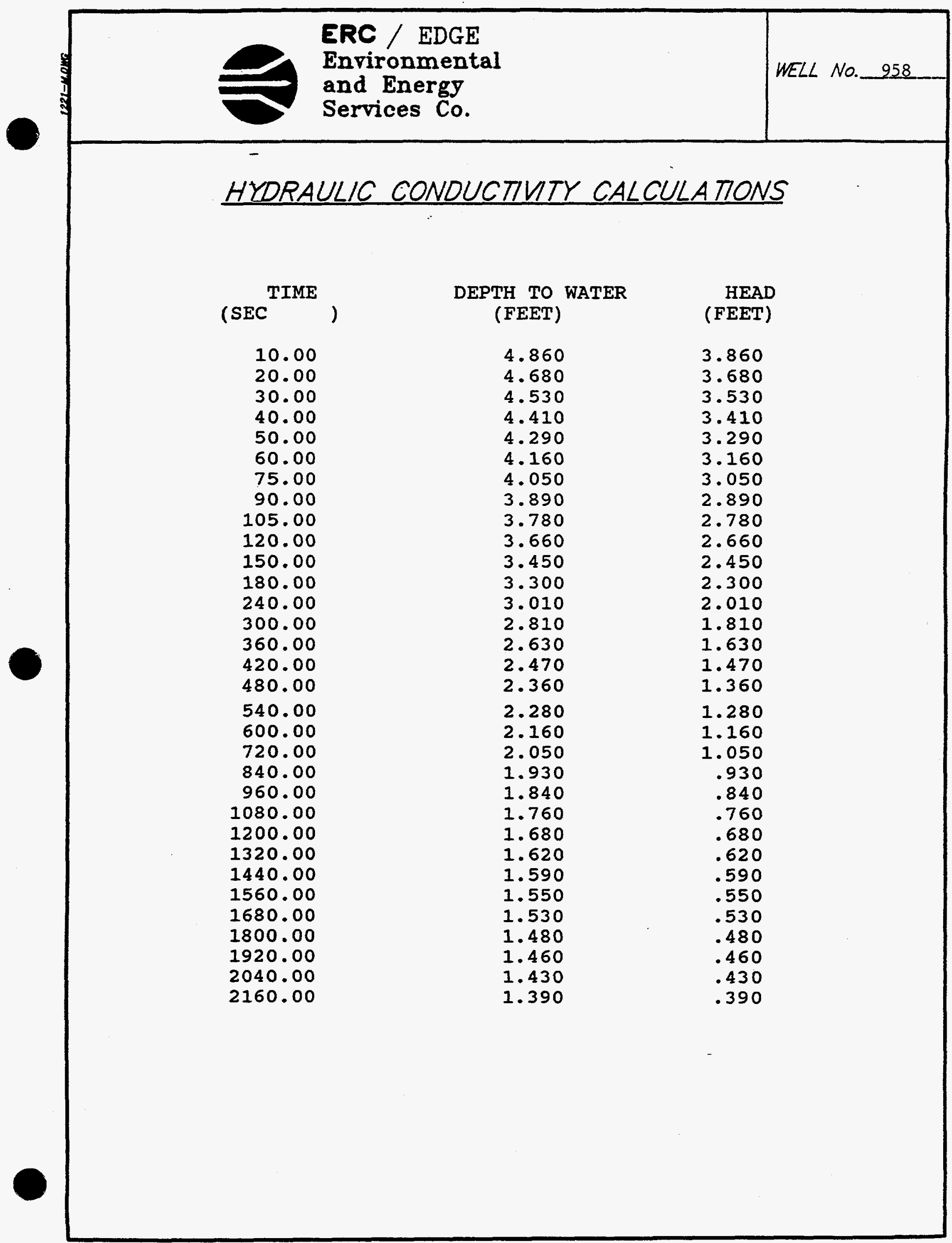

PAGE 15 of 17. 
ERC / EDGE

Environmental

and Energy

Services Co.

\section{HYDRAULIC CONDUCTIVTY CALCULATIONS}

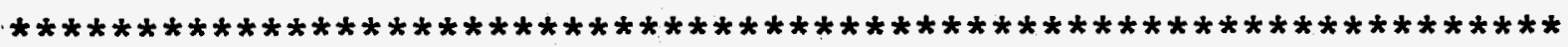
METHOD OF BOUWER AND RICE

COMPUTED RESULTS USING DIAMETER OF DRILLED HOLE:

PERMEABILITY $=7.95 \mathrm{E}-07 \mathrm{FT} / \mathrm{SEC}=2.42 \mathrm{E}-05 \mathrm{CM} / \mathrm{SEC}$

TRANSMISSIVITY $=1.19 \mathrm{E}-05 \mathrm{FT} * * 2 / \mathrm{SEC}$

COMPUTED RESULTS USING DIAMETER OF CASING AND SCREEN:

PERMEABILITY $=1.09 \mathrm{E}-06 \mathrm{FT} / \mathrm{SEC}=3.32 \mathrm{E}-05 \mathrm{CM} / \mathrm{SEC}$

TRANSMISSIVITY $=1.63 \mathrm{E}-05 \mathrm{FT} * 2 / \mathrm{SEC}$ 


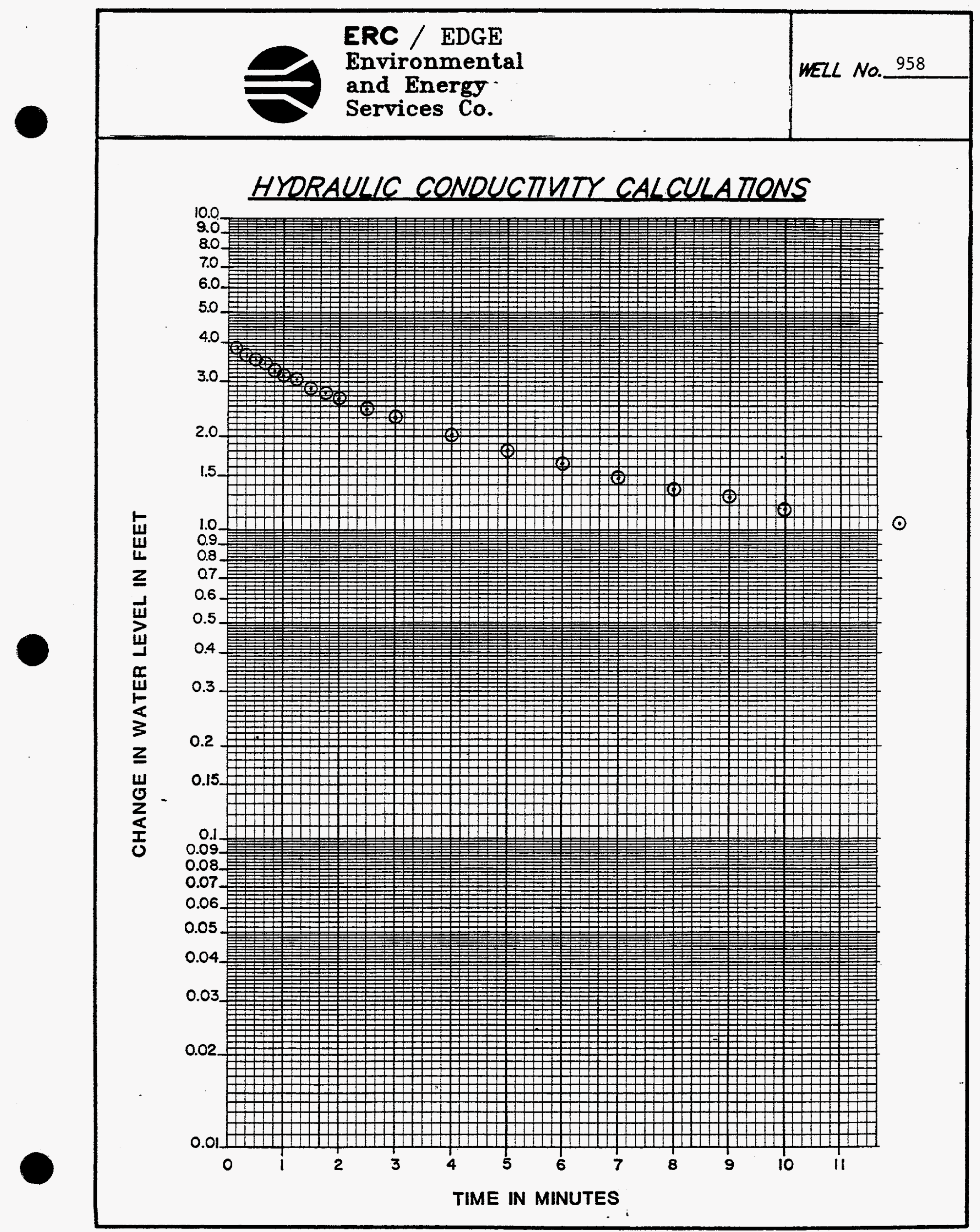




\subsection{General Information}

\section{1 mell Iocation}

Monitoring well number 959 is located in WAG 4. It is located approximately 1500 feet southwest from the intersection of Melton Valley Drive and Iagoon Road. The location is shown on ORNL drawing number C3E20004A075. Survey coordinates for this well are $N 18,729.0653, E$ $28,682.4383(\mathrm{X}-10 \mathrm{grid})$ or latitude $35^{\circ}-54^{\prime}-55.74^{\prime \prime}$ and

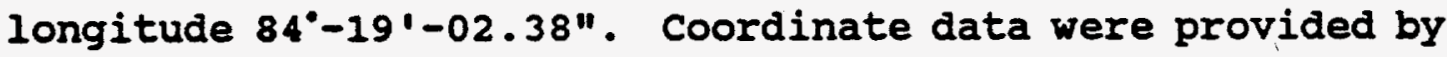
Martin Marietta Energy systems. The method used for conversion from $x-10$ grid to Tennessee-Lambert state Plane Coordinates came from the publication "Tennessee Valley Authority Data Services Branch and Mapping Services Branch, Oak Ridge, Tennessee, DOE Plant Control, November 6, 1985 , Field Book: Ess-3115, pp. 1-20." The latitude and longitude were calculated by Adams Craft Herz Walker Engineering, Inc., using methods from the U.S. Coast and Geodetic Survey Publication 62-4, "state Plane Coordinates by Automatic Data Processing."

\subsection{Drilling Information}

Well number 959 was drilled by Geotek Engineering Company. An Ingersoll Rand T-4 rig was used to drill this boring for monitor well installation under the operation of Larry Ledbetter with the assistance of Fred Dixon, Tom Doonan and Tracy Mitchel1: Drilling commenced on $3 / 28 / 90$ and was finished on 4/3/90. Paragraph 2.4.1 includes a detailed discussion of the well installation and a well schematic is included on the well installation/completion form. A synopsis of the drilling activity follows. This 
information was typed directly from field notes and was edited only when necessary for clarification.

3/28/90: The location was determined to be Class III. The rig was moved to location and set up on two sheets of plastic sheeting. Split spoon samples were taken from surface to refusal at 10.8 feet. The boring was deepened with 6-inch augers to refusal at 13.0 feet. The location was downgraded to class II at this time (the highest RAD reading was $<0.2 \mathrm{MR} / \mathrm{hr}$ ). A 22 -inch auger was used from surface to 10.0 feet (RAD = 1 $\mathrm{MR} / \mathrm{hr}$ in some roots at 5.0 feet). A 10.0 feet string of 16-inch decontaminated steel diverter casing was set and grouted to surface with 8.0 sacks cement.

3/29/90: Drill from 10.0 feet to 35.0 feet using a 14.0 inch air rotary tricone bit into a containment box $($ RAD $=0 \mathrm{MR} / \mathrm{hr}$, OVA $=<.05 \mathrm{ppm})$.

3/30/90: Set 35.0 feet decontaminated 10.0 inch steel surface casing with 50.0 lbs bentonite pellets. Grouted surface casing with 11.0 sacks cement.

4/2/90: Drill from 35.0 feet to 72.5 feet using an 8.0 inch air rotary tricone bit using a containment box $(R A D=<0.1 \mathrm{MR} / \mathrm{hr}$, OVA $=<.05 \mathrm{ppm})$.

4/3/90: Set 4 inch stainless steel screen and casing with sandpack and bentonite seal. Grout annulus with 12.0 sack cement.

This well was logged by ERC Environmental and Energy Services Co. (ERC) hydrogeologist Timothy A. Lee. All well construction materials and supplies were from Martin Marietta Energy Systems approved batches. The batch origin 
ERC / EDGE

Environmental

and Eneres

Services Co.
MONTOANG MEL PROCRAW

MIL DATA NGPRATIE

zL $\mathrm{Na} 959$

of individual items is shown on the included Monitoring Well Materials Certification form.

\subsection{Technical Information}

\subsection{Decontamination Procedures}

The drilling rig, down hole tools, surface casing, stainless steel screen, stainless steel casing, centralizers, and stainless steel silt trap underwent the cleaning decontamination procedures outlined in the drilling specifications (Release specific Technical Directions for Regulatory Compliance Monitoring Wells Phase 1, Oak Ridge National Laboratory, Oak Ridge, W.O. K-4147, April 1987, pgs. 2-4). A checklist of the cleaned materials is included with this data package.

\subsection{Geology}

WAG 4 is located in Melton Valley which is in the Valley and Ridge Physiographic Province of East Tennessee. WAG 4 is underlain by shale, siltstone, and limestone of the Middle to Upper Cambrian Conasauga Group. The Conasauga Group in the oak Ridge area consists of six formations. They are, in ascending order, the Pumpkin Valley Shale, Rutledge Limestone, Rogersville Shale, Maryville Iimestone, Nolichucky shale and the Maynardville Limestone. The Pumpkin Valley Shale and Rutledge Limestone underlie WAG 4. strike in and near WAG 4 ranges from $\mathrm{N} 85^{\circ} \mathrm{E}$ to $\mathrm{N} 15^{\circ} \mathrm{E}$ and dip varies from $27^{\circ}$ to vertical. These variations in strike and dip indicate that the conasauga has been deformed in the locale of WAG 4 . 


\section{3 sample collection}

A bulk density soil sample was collected from the split spoon sample interval from 6.0 to 6.3 feet. The sample was measured and weighed, and a bulk density of 2.24 grams $/ \mathrm{cm}^{3}$ was calculated. No samples were collected for chemical analysis.

\subsection{Installation and Development}

\subsubsection{Installation}

This was a Type B well. A 22.0-inch diameter boring was augered from ground surface to 10.0 feet. A 15 1/4-inch diverter casing was installed from surface to 10.0 feet below ground surface and grouted in place. The boring was then extended past the diverter casing depth with a 14.0inch air rotary tricone roller bit from 10.0 feet to 35.0 feet. A 10.0-inch diameter string of decontaminated steel surface casing was installed from 0.0 feet to 35.0 feet, sealed with a 2.0-foot bentonite pellet layer from 33.0 feet to 35.0 feet, and tremie-grouted in place. The surface casing minimizes potential cross contamination between the regolith and bedrock water bearing zones. After the surface casing was installed, the air rotary method was used to drill an 8-inch diameter boring to a total depth of 72.5 feet. A 4-inch diameter stainless steel screen with threaded bottom cap was installed from 51.9 feet to 72.1 feet. A 4-inch diameter stainless steel casing was installed from the top of the screen at 51.9 feet and extended 3.1 feet above ground surface. A sandpack was then tremied into the annular space from 72.1 feet up to 49.0 feet, with a 2.2 -foot bentonite pellet seal 
poured into the annular space above the sandpack from 46.8 to 49.0 feet. The annular space from the top of the bentonite seal to the surface was tremie grouted with a cement/bentonite slurry. A detailed schematic of the well is included on the well installation/completion form.

\section{4 .2 well Development}

Well number 959 was developed to remove drill cuttings, silt, and other fines. The monitoring well was developed using a Geoguard pump with an air compressor. All pumps were cleaned prior to use according to specified cleaning procedures (see Paragraph 2.1). The well was developed until a measured total of 556 gallons of water had been evacuated and the clarity of the discharge water was approved by the company representative. The final turbidity value measured at completion was 5.0 NTU's. A development form showing the exact method of development and other pertinent data is appended.

\subsubsection{Instaliation of Dedicated Monitoring well Pump}

After the well was developed, a Geoguard Model No. 5614 dedicated monitoring well pump was installed on 10/11/90 at a depth of 69.4 feet below ground surface. These pumps are decontaminated at American sigma and are sent prepackaged. A copy of the pump certification is kept on file at ORNL.

\subsection{Hydraulic Conductivity Testing}

Well number 959 was tested for the determination of hydraulic conductivity of the aquifer in the vicinity of the well screen. This was accomplished by instantaneously 
adding a known quantity of water to the monitoring well and measuring the recovery of the water level over time. The changing water levels were measured using a Druck 15 psi pressure transducer and an Omnidata Datapod II data recorder. The hydraulic conductivity value of $1.36 \times 10^{\circ 6}$ $\mathrm{cm} /$ second (shown as permeability on the hydraulic conductivity calculations printout attached) was calculated using the Bouwer and Rice method. A computer printout of the hydraulic conductivity calculations is included in this data package. 


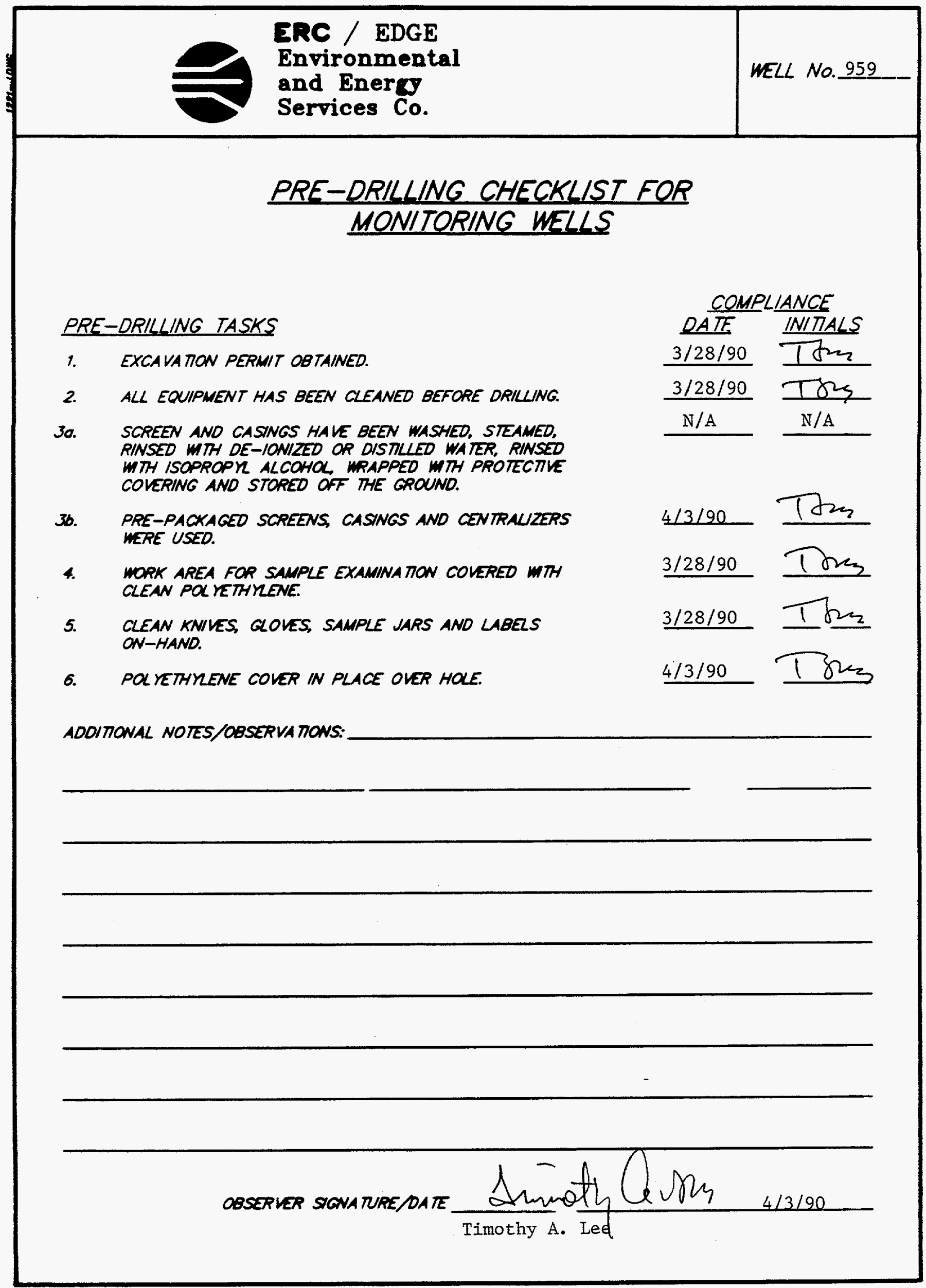

PAGE 7 of 21 . 
ERC / EDGE

Environmental

and Energy

WELL NO. 259

Services Co.

DECONTAMINATION CHECKLIST

DRILLING EQUIPMENT

\begin{tabular}{|c|c|c|c|c|c|}
\hline EQUIPMENT & SCRAPE & $\begin{array}{l}\text { STEAN } \\
\text { CLEAN }\end{array}$ & $\begin{array}{l}\text { STEAM } \\
\text { RINSE }\end{array}$ & $\begin{array}{c}\text { 1SOPROPY } \\
\text { ALCOHOL } \\
\text { RINSE }\end{array}$ & $\begin{array}{c}\text { DEIONIZEO } \\
\text { WATER } \\
\text { RINSE }\end{array}$ \\
\hline$R / G$ & $\mathrm{X}$ & $\mathrm{X}$ & $\mathrm{X}$ & $N / A$ & $N / A$ \\
\hline AUGERS & $\mathrm{x}$ & $\mathrm{X}$ & $\mathrm{x}$ & $\mathrm{x}$ & $\mathrm{X}$ \\
\hline BITS & $\mathrm{x}$ & $x$ & $\mathrm{x}$ & $\mathrm{X}$ & $\mathrm{x}$ \\
\hline ROOS & $\mathrm{X}$ & $\mathrm{X}$ & $\mathrm{x}$ & $\mathrm{X}$ & $\mathrm{X}$ \\
\hline SAMPLERS & $x$ & $x$ & $x$ & $x$ & $x$ \\
\hline PIPES & $\mathrm{x}$ & $\mathrm{X}$ & $\mathrm{x}$ & $\mathrm{x}$ & $\mathrm{X}$ \\
\hline WORK TOOLS & $\underline{x}$ & $x$ & $x$ & $\underline{x}$ & $\mathrm{x}$ \\
\hline AUGER PINS & $\mathrm{x}$ & $\mathrm{X}$ & $\mathrm{X}$ & $\mathrm{x}$ & $\mathrm{x}$ \\
\hline & & & & & \\
\hline & & & & & \\
\hline & & & & & \\
\hline
\end{tabular}

OBSERVER SIGNATURE/DATE $\frac{\text { Amoff }}{\text { Timothy A. Lee }}$ 


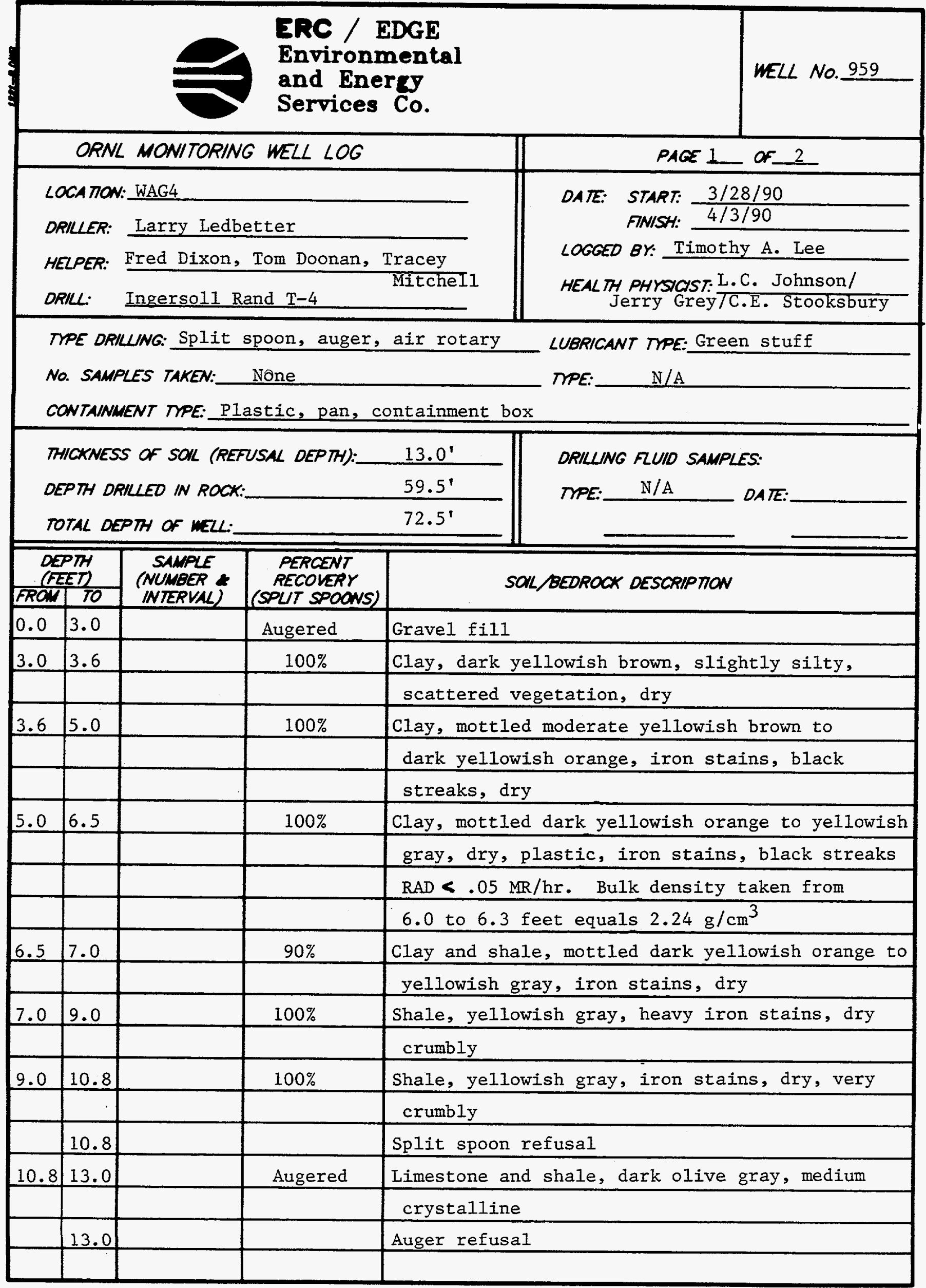




\begin{tabular}{|c|c|c|c|c|c|}
\hline & & $\mathbf{P}$ & $\begin{array}{l}\text { ERC / ED } \\
\text { Environm } \\
\text { and Ener } \\
\text { Services }\end{array}$ & $\begin{array}{l}\text { LDGE } \\
\text { nental } \\
\text { reg } \\
\text { Co. }\end{array}$ & WELL No._959 \\
\hline & ORNL & MONITORINC & WELL LOG & & or 2 \\
\hline $\begin{array}{l}\text { DEP } \\
\text { SFEE } \\
\text { FROWI }\end{array}$ & $\frac{P T 1}{10}$ & $\begin{array}{c}\text { SAMPLE } \\
\text { (NUNEER } \\
\text { INTERVAL) }\end{array}$ & $\begin{array}{c}\text { PERCENT } \\
\text { RECOVIERY } \\
\text { (SPUT SPOONS) }\end{array}$ & & \\
\hline 13.0 & 35.0 & & Air Rotary & $\star *$ Limes & \\
\hline 35.0 & 45.5 & & & Limest & \\
\hline 45.5 & 47.5 & & & Shale, & \\
\hline 47.5 & 67.0 & & & Limest & \\
\hline 67.0 & 69.5 & & & Shale, & \\
\hline 69.5 & 72.5 & & & Limest & \\
\hline & 72.5 & & & Total & \\
\hline & & & & & \\
\hline & & & & & \\
\hline & & & & ** No & iption available \\
\hline & & & & fro & o the use of a \\
\hline & & & & con & \\
\hline & & & & & \\
\hline & & & & & \\
\hline & & & & & \\
\hline & & & & & \\
\hline & & & & & \\
\hline & & & & & \\
\hline & & & & & \\
\hline & & & & & \\
\hline & & & & & \\
\hline & & & & & \\
\hline & & & & & \\
\hline & & & & & \\
\hline & & & & & \\
\hline & & & & & \\
\hline & & & & & \\
\hline & & & & & \\
\hline & & & & & \\
\hline & & & & & \\
\hline & & & & & \\
\hline & & & & & \\
\hline & & & & & \\
\hline
\end{tabular}




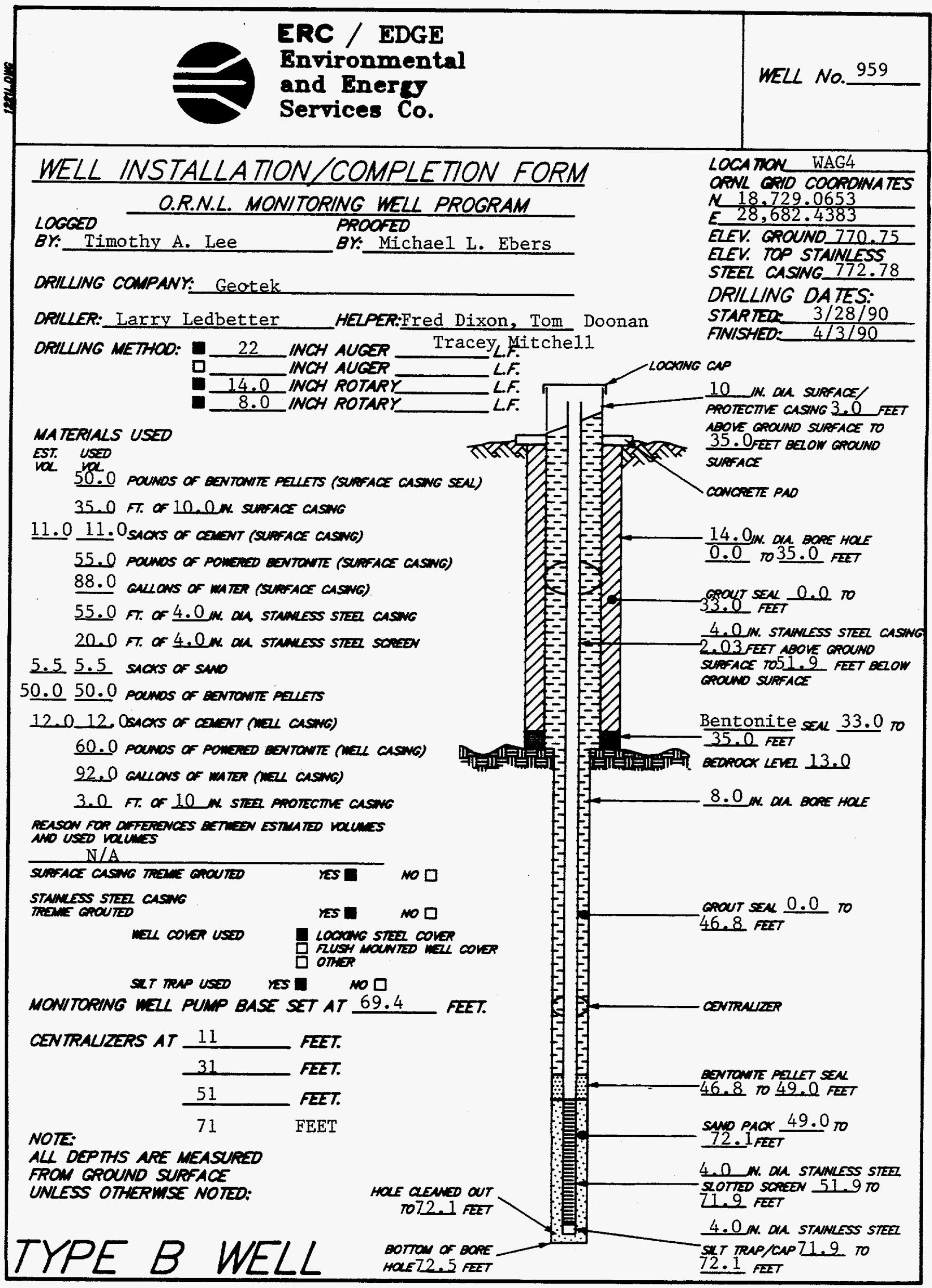

PACE 11 of 21 
ERC / EDGE

Environmental

WELL No.259

and Energy

Services Co.

DATE: $4 / 3 / 90$

\section{MONITORING WELL MATERIALS CERTIFICATION}

ITEM/MA TERIAL

SAND

BENTONITE

owder

Pellets

STAINLESS STEEL SCREEN

STAINLESS STEEL CASING

STAINLESS STEEL CENTRALIZERS

STAINLESS STEEL CAPS

MONITORING WELL PUMP

GROUT

urface casing

we11 casing

WELL COVERS

SURFACE CASING

(PREPACKAGED

(PREPACKAGED

(PREPACKAGED

(PREPACKAGED

(PREPACKAGED

DATE USED

BATCH NUMBER

\begin{tabular}{|l|l}
\hline & \\
\hline $4 / 3 / 90$ & 6 \\
\hline $4 / 3 / 90$ & 4 \\
\hline $4 / 3 / 90$ & 5 \\
\hline
\end{tabular}

\begin{tabular}{l|l|l} 
TES & $4 / 3 / 90$ & 3
\end{tabular}

YES

NO $4 / 3 / 90$

YES)

nO $4 / 3 / 90$

YES
NO

$4 / 3 / 90$

YES

\begin{tabular}{|l|l}
\hline $10 / 11 / 90$ & 8
\end{tabular}

$3 / 30 / 90$

7

\begin{tabular}{l|l}
\hline $4 / 3 / 90$ & 7
\end{tabular}

$3 / 30 / 90$

5

COMMENTS:

OBSERVER SIGNATURE DATE 


\section{POST-MELL COMPLETION CHECKLIST}

\section{POST-MELL COMPLETION TASKS}

1. WUO SCRAPED FROW AUGERS SMMPLERS ANO ALL

$4 / 3 / 90$ OTHER EQUIPWENT.

2. ALL WUD RRON RIG ANO EQUIPUENT SCRAPWOS ANO CUTINOS OSPOSEO OF IN ACCOROANCE WITH THE SPECAFCA IION PROWDED.

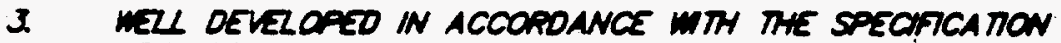
PROVOEO ANO OETAKS OF THE OEVZ OOMENT ACHUT RECOROSD.

4. DRULWG SITE PROPERLY CLEANED UP AFTER CONPLETION of nIU INSTALU ION.

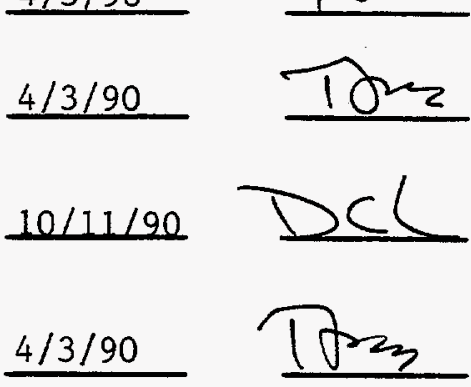

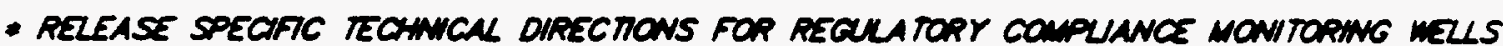
PHASE 1. OAK RIDGE NATONAL LABORATOPY, OAK RIDEE M. K-4147, APRK 1987.

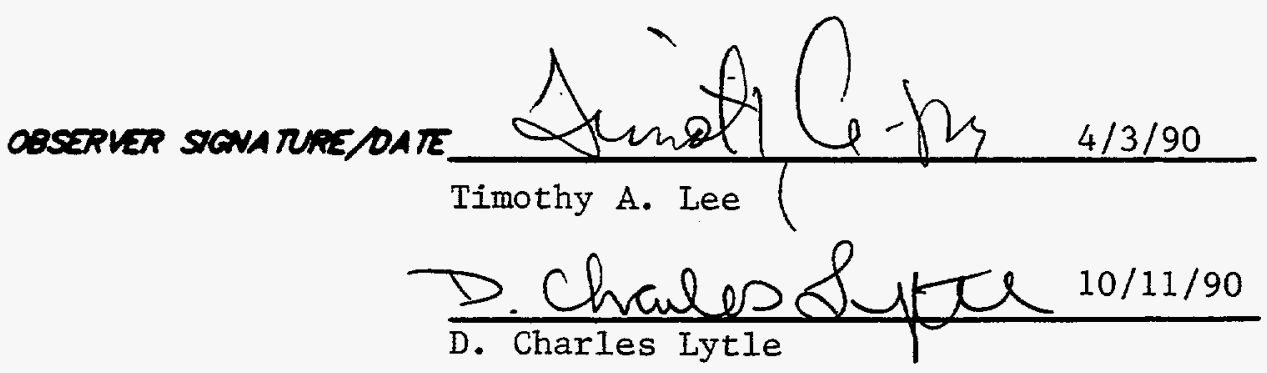




\section{MONITORING WELL \\ DEVELOPMENT FORM}

DEVELOPMENT DETAILS

METHOD OF

DEVELOPMENT: Pumping with Geoguard pump

DEVELOPMENT

BEGAN DATE:

$8 / 13 / 90$

TME:

DEVELOPMENT

ENDING DATE:

$10 / 11 / 90$

DEVELOPMENT

OBSERVED BY:

D. Charles Lytle

ONE WELL VOLUME: 60.2 GALLONS

TOTAL GALLONS PUMPED: 556 TOTAL WELL VOLUMES PUMPED: 9.2

INITAL PH: 9.9 FNAL PH: 10.4

INITAL CONDUCTUTY (KS/CO $): 814$

DESCRIPTION OF INITAL TURBIOITY: Cloudy

FNAL CONOUCTUTY ( $\mu \mathrm{S} / \mathrm{cm}): 741$

DESCRIPTION OF FNAL TURBIDITY:_Clear

FNAL MEASURED TURBIDITY: 5.0 NTU'S

WELL APPROVED BY: R.C. Williams MMES

ODOR

OF WAIER: None

WATER $\square$ GROUND SURFACE

DISCHARGED I STORM SEMERS

TO:

D ORUNS

TANK TRUCK

O STORAGE TANKS

口 OTHER

INITAL PRE-DEVELOPMENT

WATER DEP TH: $\quad 4.5$ feet from ground surface

\section{DEVELOPMENT OBSERVATONS}

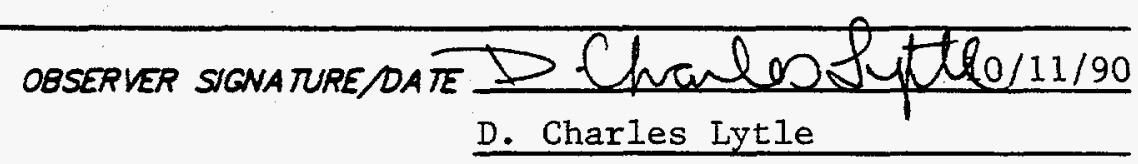




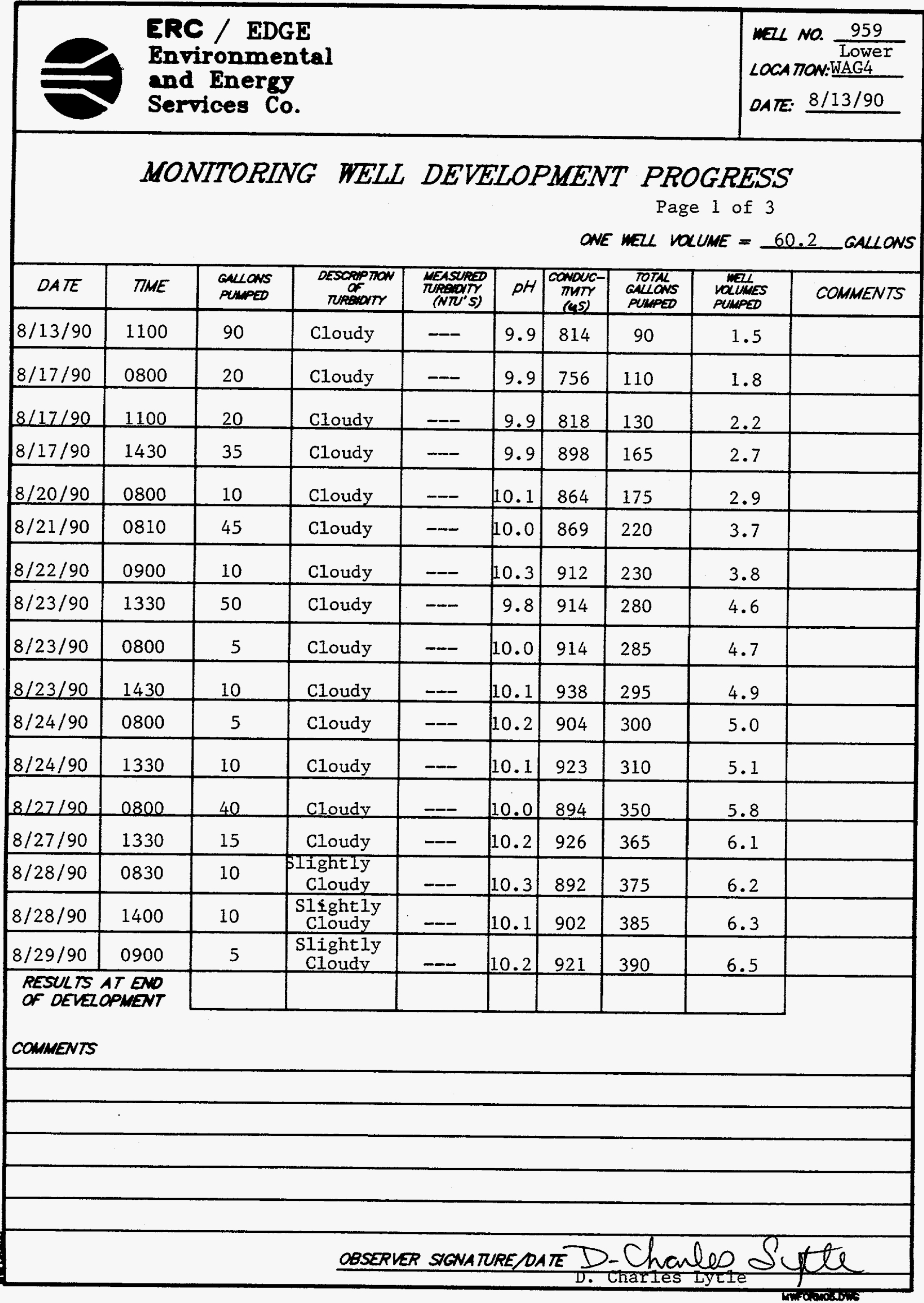




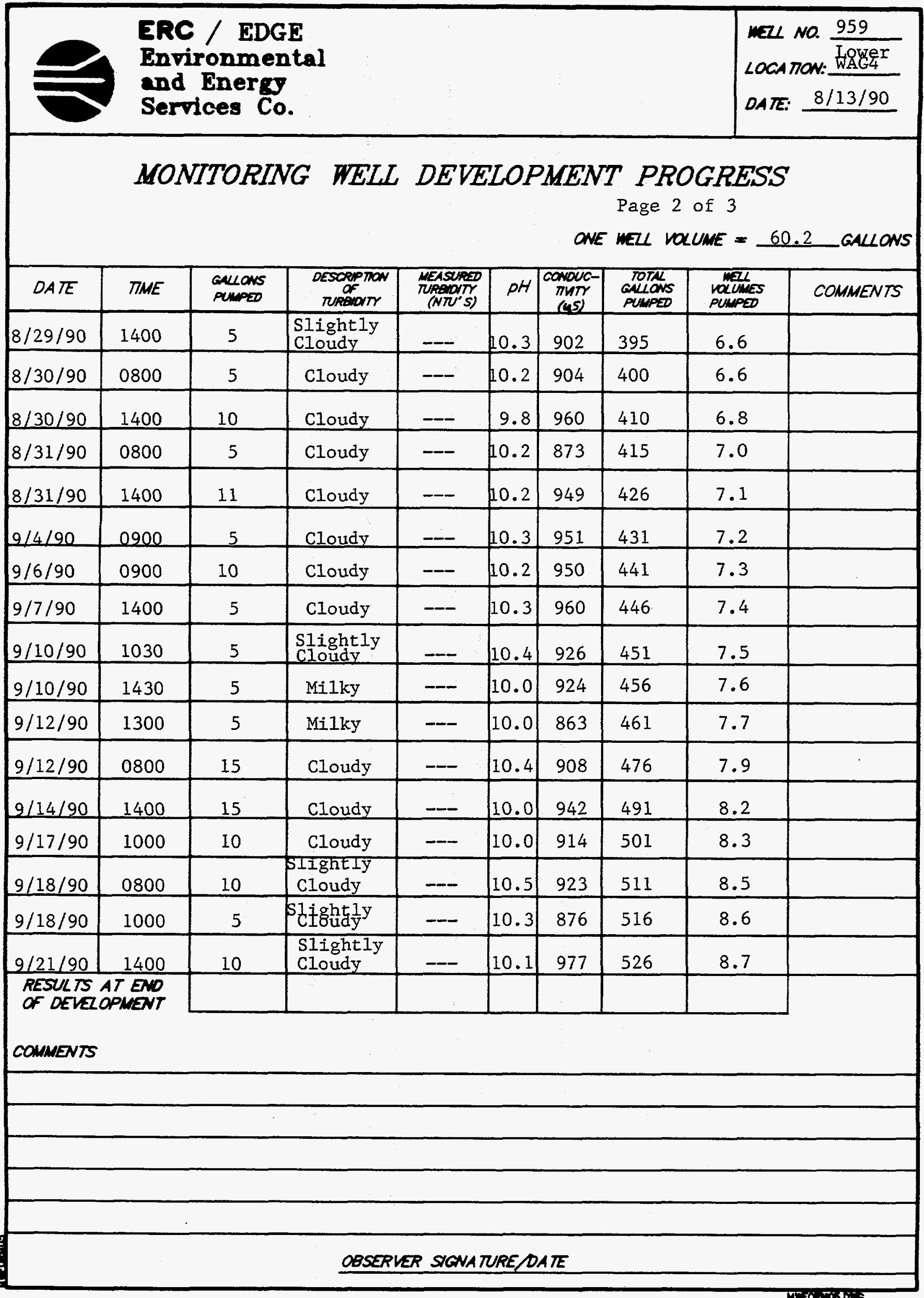




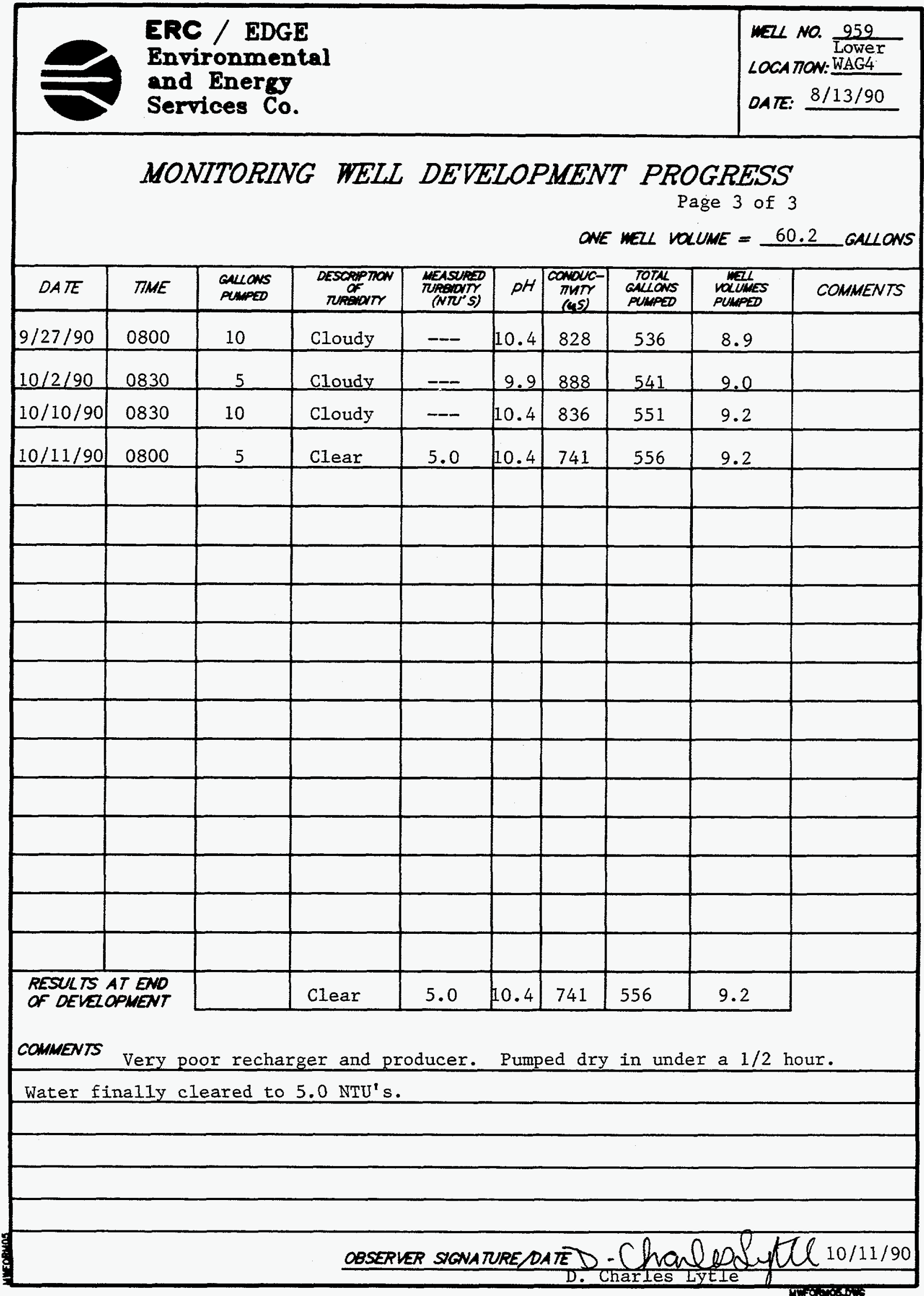




\title{
HYORAULIC CONDUCTIVTY CALCULATIONS
}

\author{
PROGRAM SLUGT, VERSION 4.1, NOV. 1986
}

THIS PROGRAM CALCULATES MEAN TRANSMISSIVITIES FROM SLUG-TEST DATA BASED ON TWO ANALYTICAL APPROACHES:

(1) METHOD OF COOPER, BREDEHOEFT AND PAPADOPULOS, 1967 (ARTICLE IN VOL.3, NO.I OF WRR ENTITLED

"RESPONSE OF A FINITE DIAMETER WELL TO AN INSTANTANEOUS CHARGE OF WATER")

(2) METHOD OF BOUWER AND RICE, 1976 (ARTICLE IN VOL. 12, NO.3 OF WRR ENTITLED

"A SLUG TEST FOR DETERMINING HYDRAULIC CONDUCTIVITY OF UNCONFINED AQUIFERS WITH COMPLETELY OR PARTIALLY PENETRATING WELIS")

WELL NO. : 959

DATE OF TEST: $10-30-90$

PROJECT NO.: E221-002

CLIENT: MMES

SITE LOCATION: WAG -4

EDGE, INC. FIELD INVESTIGATOR: JAMES W. CARUTHERS

INPUT DATA ARE:

INNER CASING DIAMETER $=4.00$ INCHES

INNER SCREEN OR OPEN-HOLE DIAMETER $=4.00$ INCHES

DIAMETER OF DRILLED HOLE $=8.00$ INCHES

LENGTH OF SCREEN OR INTAKE PORTION $=20.00$ FEET

DEPTH FROM STATIC LEVEL TO BOTTOM OF SCREEN $=51.25$ FEET

THICKNESS OF SATURATED AQUIFER ZONE $=20.00$ FEET

DEPTH TO STATIC WATER LEVEL BELOW REF. POINT $=1.00$ FEET ESTIMATED POROSITY OF GRAVEL PACK $=.20$

FALLING-HEAD INDEX $=1$ ("I" IF FALLING, "0" IF RISING)

NUMBER OF DEPTH-TIME DATA POINTS = 32

HO WAS COMPUTED FROM INTERCEPT OF PLOT OF LOG(H) VS. TIME

\author{
SUCCESSIVE COMPUTED \\ VALUES FOR HO \\ (FEET)
}

2.5847

2.5854 


\section{HYDRAULIC CONDUCTIVTY CALCULATIONS}

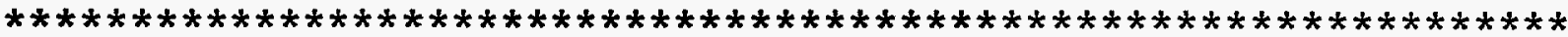

METHOD OF BOUWER AND RICE

COMPUTED RESULTS USING DIAMETER OF DRILIED HOLE:

PERMEABILITY $=4.45 \mathrm{E}-08 \mathrm{FT} / \mathrm{SEC}=1.36 \mathrm{E}-06 \mathrm{CM} / \mathrm{SEC}$

TRANSMISSIVITY $=8.89 \mathrm{E}-07 \mathrm{FT} * 2 / \mathrm{SEC}$

COMPUTED RESULTS USING DIAMETER OF CASING AND SCREEN:

PERMEABILITY $=5.15 \mathrm{E}-08 \mathrm{FT} / \mathrm{SEC}=1.57 \mathrm{E}-06 \mathrm{CM} / \mathrm{SEC}$

TRANSMISSIVITY $=1.03 \mathrm{E}-06 \mathrm{FT} * 2 / \mathrm{SEC}$ 


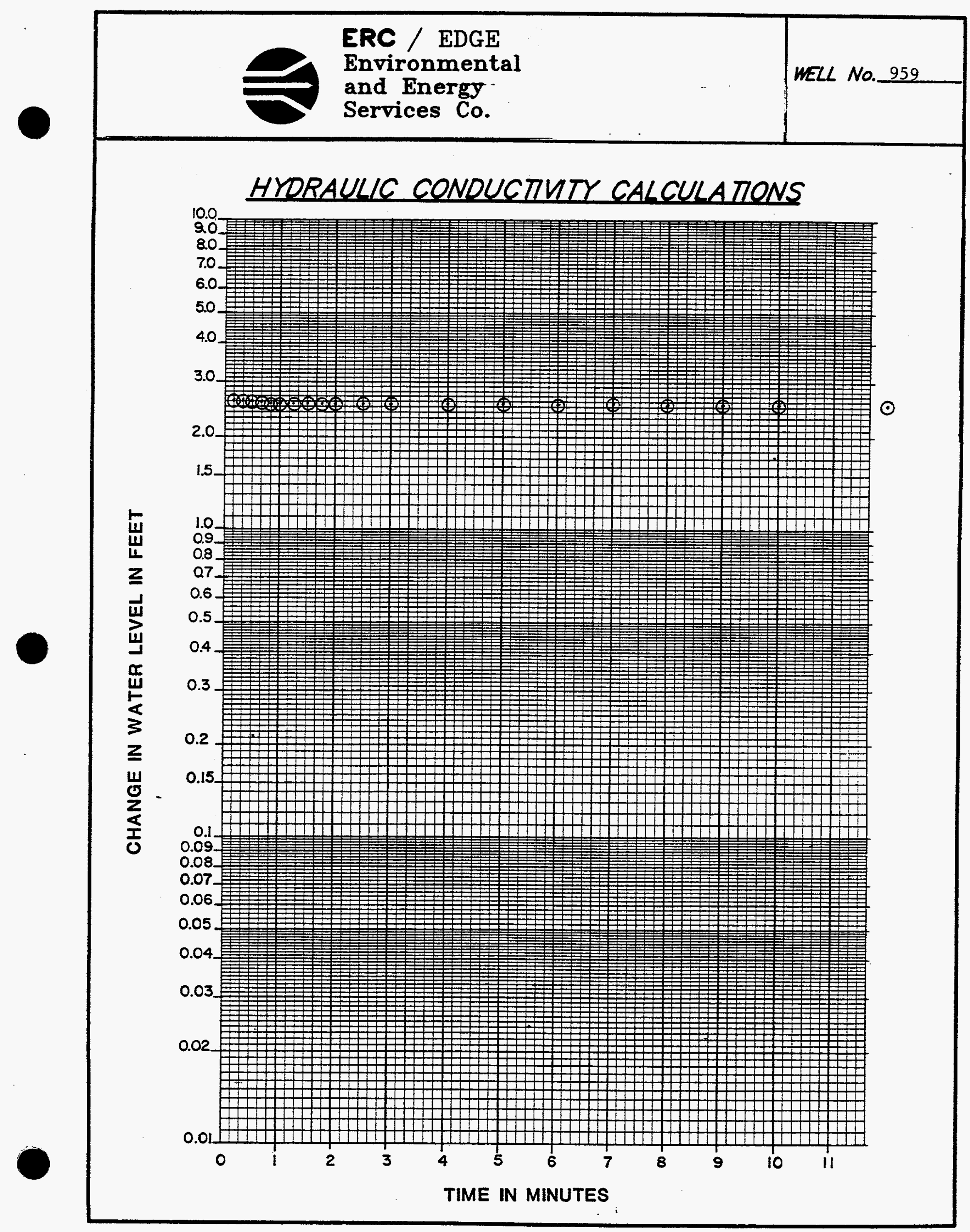

PACE 21 of 21 
1.0 General Information

\subsection{We11 Location}

Monitoring well number 960 is located in WAG 4. It is located approximately 1500 feet southwest from the intersection of Melton Valley Drive and Lagoon Road. The location is shown on ORNL drawing number C3E20004A075. Survey coordinates for this well are $N 18,742.0354$, E $28,674.3737\left(X-10\right.$ grid) or latitude $35^{\circ}-54^{\prime}-55.81^{\prime \prime}$ and longitude $84^{\circ}-19^{\prime}-02.55^{\prime}$. Coordinate data were provided by Martin Marietta Energy systems. The method used for conversion from $\mathrm{X}-10$ grid to Tennessee-Lambert state Plane Coordinates came from the publication "Tennessee Valley Authority Data Services Branch and Mapping Services Branch, Oak Ridge, Tennessee, DOE Plant Control, November 6, 1985, Field Book: Ess-3115, pp. 1-20." The latitude and longitude were calculated by Adams craft Herz Walker Engineering, Inc., using methods from the U.S. Coast and Geodetic Survey Publication 62-4, "State Plane coordinates by Automatic Data Processing.".

\subsection{Drilling Information}

Well number 960 was drilled by Geotek Engineering Company. An Ingersoll Rand T-4 rig was used to drill this boring for monitor well installation under the operation of Larry Ledbetter with the assistance of Fred Dixon, Tom Doonan and Tracy Mitchell. Drilling commenced on $3 / 30 / 90$ and was finished on 4/4/90. Paragraph 2.4.1 includes a detailed discussion of the well installation and a well schematic is included on the well installation/completion form. A synopsis of the drilling activity follows. This 
information was typed directly from field notes and was edited only when necessary for clarification.

3/30/90: This location was determined to be a class III. Moved rig to location and set up a two layers of plastic sheeting. Augered from surface to 10.0 feet using a 14.0 inch auger $(R A D=<0.1 \mathrm{MR} / \mathrm{hr}$, OVA $=<.05 \mathrm{ppm})$. The location was downgraded to Class II. Set 10.0 feet of decontaminated 10.0 inch steel diverter casing. Grouted annulus with 5.0 sacks cement.

4/3/90: Drill from 10.0 to 32.5 feet using an 8.0 inch air rotary tricone bit into containment box (RAD $=<0.1 \mathrm{MR} / \mathrm{hr}$, OVA $=<.05 \mathrm{ppm})$.

4/4/90: Set 2.0 inch stainless steel screen and casing with sandpack and bentonite seal. Grouted annulus with 4.5 sacks cement.

This well was logged by ERC Environmental and Energy Services Co. (ERC) hydrogeologist Timothy A. Lee. All well construction materials and supplies were from Martin Marietta Energy Systems approved batches. The batch origin of individual items is shown on the included Monitoring Well Materials Certification form.

2.0 Technical Information

\subsection{Decontamination Procedures}

The drilling rig, down hole tools, surface casing, stainless steel screen, stainless steel casing, centralizers, and stainless steel silt trap underwent the cleaning decontamination procedures outlined in the 
drilling specifications (Release Specific Technical Directions for Regulatory Compliance Monitoring Wells Phase 1, Oak Ridge National Laboratory, Oak Ridge, W.0. K-4147, April 1987, pgs. 2-4). A checklist of the cleaned materials is included with this data package.

\subsection{Geology}

WAG 4 is located in Melton Valley which is in the Valley and Ridge Physiographic Province of East Tennessee. WAG 4 is underlain by limestone, siltstone and limestone of the Middle to Upper Cambrian Conasauga Group. The Conasauga Group in the oak Ridge area consists of six formations. They are, in ascending order, the Pumpkin Valley Shale, Rutledge Limestone, Rogersville Shale, Maryville Iimestone, Nolichucky Shale and the Maynardville Limestone. The pumpkin Valley Shale and Rutledge Limestone underlie WAG 4. strike in and near WAG 4 ranges from $N 85^{\circ} \mathrm{E}$ to $\mathrm{N} 15^{\circ} \mathrm{E}$ and dip varies from $27^{\circ}$ to vertical. These variations in strike and dip indicate that the conasauga has been deformed in the locale of WAG 4.

\section{3 sample collection}

No samples were collected.

\subsection{Installation and Development}

\subsubsection{Installation}

This was a Type D we11. A 14.0-inch diameter boring was augered from ground surface to 10.0 feet. The air rotary method was required to complete the boring to the specified 
ERC / EDGE

Environmental

and Energy

Services Co.
MONTORWE WZL PROCPAN

UZL DATA NARRATVE

wre $\mathrm{Na} 960$

total well depth. Therefore, a 10.0-inch diverter casing was installed and grouted. An 8-inch diameter boring was then drilled with an air rotary tricone roller bit from 10.0 to 32.5 feet. A 2-inch diameter stainless steel screen with threaded bottom cap was installed from 17.2 to 32.5 feet. A 2-inch diameter stainless steel casing was installed above the screen at 17.2 feet and extended 2.08 feet above ground surface. A sandpack was then tremied into the annular space from 32.5 feet up to 14.5 feet, with a 3.3-foot bentonite pellet seal poured into the annular space above the sandpack form 11.2 to 14.5 feet. The annular space from the top of the bentonite seal to the surface was tremie-grouted with a cement/bentonite slurry. A detail of the well is included on the well installation/completion form.

\subsubsection{Well Development}

Well number 960 was developed to remove drill cuttings, silt, and other fines. The monitoring well was developed using a Geoguard pump with an air compressor. All pumps were cleaned prior to use according to specified cleaning procedures (see Paragraph 2.1). The well was developed until a measured total of 165 gallons of water had been evacuated and the clarity of the discharge water was approved by the company representative. The final turbidity value measured at completion was 5.0 NTU's. A development form showing the exact method of development and other pertinent data is appended. 


\subsubsection{Installation of Dedicated Konitoring well Pump}

After the well was developed, a Geoguard Model No. 5614 dedicated monitoring well pump was installed on 8/17/90 at a depth of 32.2 feet below ground surface. These pumps are decontaminated at American sigma and are sent prepackaged. A copy of the pump certification is kept on file at ORNL.

\subsection{Hydraulic Conductivity Testing}

Well number 960 was tested-for the determination of hydraulic conductivity of the aquifer in the vicinity of the well screen. This was accomplished by instantaneously adding a known quantity of water to the monitoring well and measuring the recovery of the water level over time. The changing water levels were measured using a Druck 15 psi pressure transducer and an omnidata Datapod II data recorder. The hydraulic conductivity value of $2.46 \times 10^{-5}$ $\mathrm{cm} / \mathrm{second}$ (shown as permeability on the hydraulic conductivity calculations printout attached) was calculated using the Bouwer-and Rice method. A computer printout of the hydraulic conductivity calculations is included in this data package. 
ERC / EDGE

Environmental

and Eneres

WELL NO. 960

Services Co.

\section{PRE-DRILLING CHECKLIST FOR MONITORING WELLS}

PRE-DRILLING TASKS

1. EXCAVATION PERMIT OBTAINED.

2. ALL EQUIPMENT HAS BEEN CLEANED BEFORE DRILUNG.

3a. SCREEN AND CASINGS HAVE BEEN WASHED, STEAMED, RINSED WITH DE-IONIZED OR OISTLLED WATER, RINSED WTH ISOPROPY ALCOHOL MRAPPED WTH PROTECTVE COVERING AND STORED OFF THE GROUND.

36. PRE-PACKAGED SCREENS, CASINGS AND CENTRALILERS WERE USED.

4. WORK AREA FOR SAMPLE EXAMINATION COVERED MTH CLEAN POC YETHRENE.

5. CLEAN KNIVES, QLOVES, SAMPLE JARS AND LABELS ON-HAND.

6. POL YETHRENE COVER IN PLACE OVER HOLE.

COMPLIANCE

DATE INITALS

$3 / 30 / 90$ The

3/30/90 T/2m3

$\mathrm{N} / \mathrm{A} \quad \mathrm{N} / \mathrm{A}$

$4 / 4 / 90 T / 2$

4/4/90 Tors

3/30/90 Tons

4/4/90 1723

AOOIMONAL NOTES/OBSERVATONS:

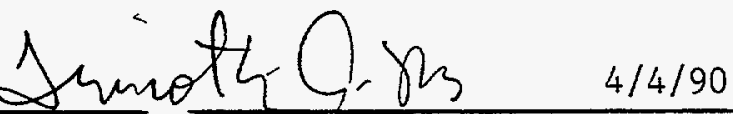

Timothy A. Lee 


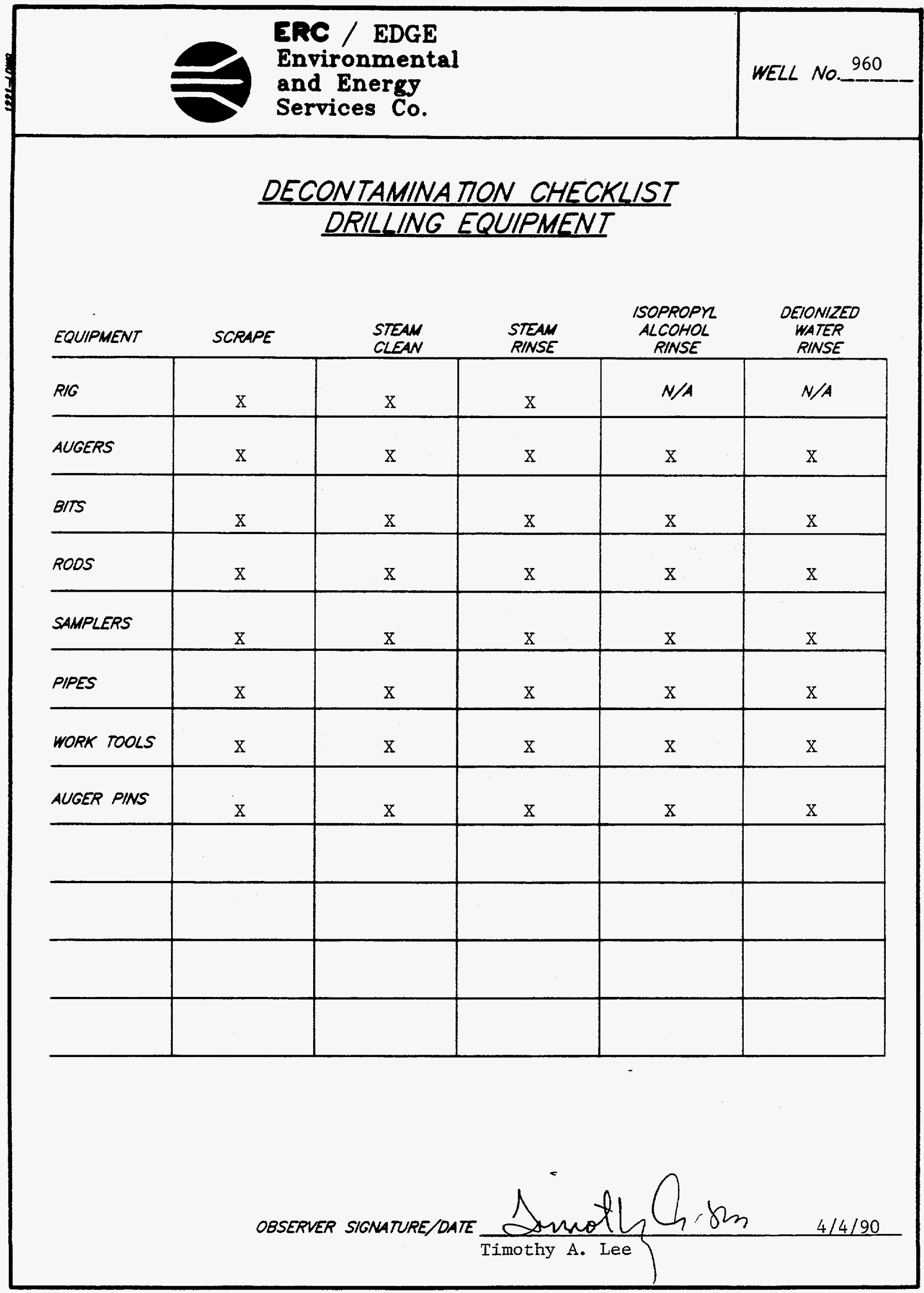




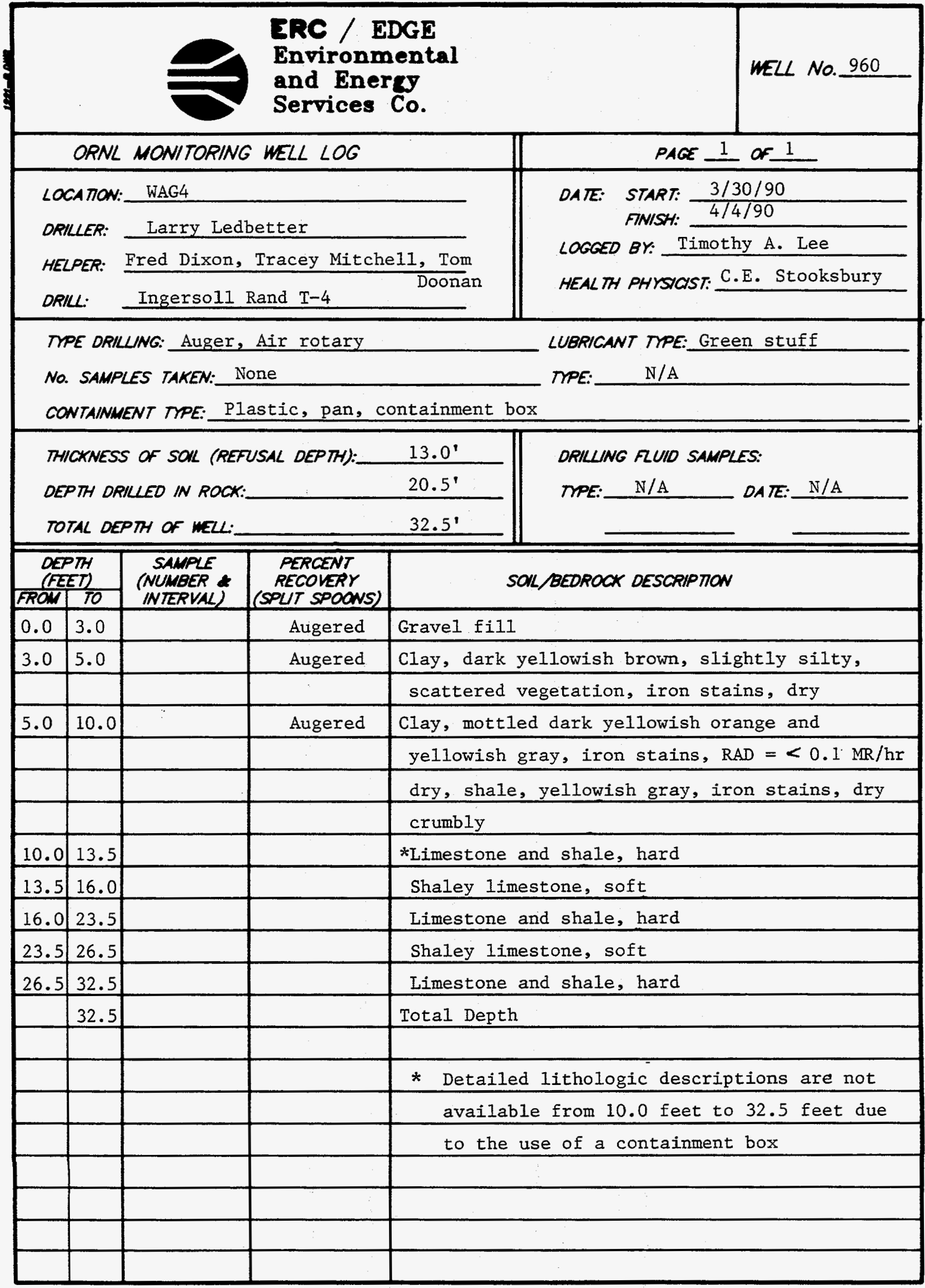


ERC / EDGE

Environmental

and Energy

WELL No. 260

Services Co.

WELL INSTALLATION/COMPLETION FORM

$\angle O G G E D$

O.R.N.L. MONITORING WELL PROGRAM

$B Y$ : Timothy Lee, Bruce

PROOFED

$B Y_{\text {: Michael L. Ebers }}$

ORILLNG COMPANY: Geotek

McMaster

LOCA TON WAG4

ORN GRID COORDINATES

$N 18,742.0354$

E $28,674.3737$

ELEV. GROUND 770.94

ELEV. TOP STAINLESS

STEEL CASING 773.02

DRILLING DATES:

ORIUER: Larry Ledbetter

HELPER:Fred Dixon, Tracey Mitchell

STARTED: $3 / 30 / 90$

FNISHED: $4 / 4 / 90$

EQUIPMENT a 14 INCH AUGER 10 L.F. Tom Doonan

LOOXING STEE COVER

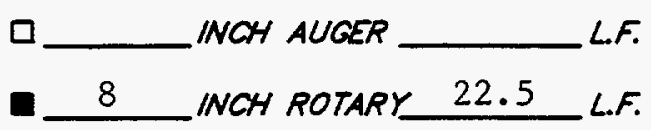

MATERIALS USED

EST. USED

VOL. VOL.

15.0 FEET OF 2 IN. S.S. SCREEN

20.0 FEET OF 2 IN. S.S. CASING

4.04 .5 SACKS OF SAND

50 50 POUNOS OF BENTONITE PELLETS

3.54 .5 SACKS OF CEMENT

17.5 POUNDS OF POWOERED BENTONITE

28.0 GALLONS OF WATER (CEMENTING)

REASON FOR DIFFERENCES BETWEEN ESTMATIED

VOLUMES AND USED VOLUMES

Fractures and spillage

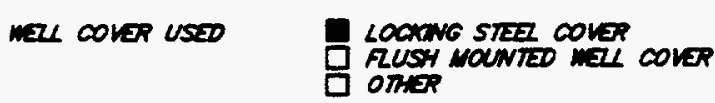

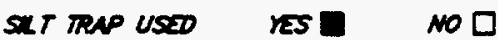

MONITORING WELL PUMP BASE SET AT 32.2 FEET.

$$
\begin{array}{r}
\text { CENTRALIZERS AT } \frac{19.5}{31.0} \text { FEET. } \\
\text { FEET. } \\
\text { FEET. }
\end{array}
$$

NOTE:

ALL DEPTHS ARE MEASURED

FROM GROUND SURFACE

UNLESS OTHERMSE NOTED:

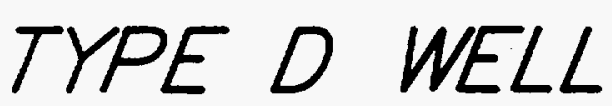

HOLE AENED OUT

To 32.5 FET

Botrow of Barerace

32.5 RET
8 NOH OMMETER STEEZ PROTECTVE CASING 3.04 fT. ABOVE GROUNO TO 2.0 FT. BELOW CROWNO SURFACE

CONCRETE PAD

10 NOH OUERTER CASING 0.0 FT. ABOVE CROUNO SURFACE TO

10.0 FT. BEOW GROUND SURFACE

14 NOH BORETOE $0 \quad \pi 10$ Fख्या

EROUT SEN 0.0 To 11.2 FEET

\section{NOH DIAMETER} BOREHOLE

2 NCH OMWETER STANLESS STER CASNG 2.08 RT. MBOVE GRONO SUPFACE TO 17.2 fT. BZZOW GROND SUAFACE

CONTRALIR (TPP.)

ESNTONTE PEIET SEN 11.2 ro 14.5 faE

SWO PACX

14.5 ro 32.5 FEI

2 NOH OHMETER staneess stzz 0.010

17.2 20 T2 32.2 FET

2 NOH OMANETER STANLESS STER SRT TRAP/CAP

32.2 ro 32.5 FET

NOT TO SCALE 


\section{ERC / EDGE}

Environmental

WELL NO. 960

and Energy

Services Co.

OATE: $4 / 4 / 90$

\section{MONITORING WELL MATERIALS \\ CERTIFICATION}

ITEM/MATERIAL

\begin{tabular}{|c|c|c|}
\hline & DATE USED & BATCH NUMBEP \\
\hline & $4 / 4 / 90$ & 6 \\
\hline & $4 / 4 / 90$ & 4 \\
\hline & $4 / 4 / 90$ & 5 \\
\hline $\begin{array}{cc} \\
0 & \text { VES } \\
\end{array}$ & $4 / 4 / 90$ & 3 \\
\hline $\begin{array}{c}\text { reS } \\
\square \text { NO } \\
\end{array}$ & $4 / 4 / 90$ & 3 \\
\hline $\begin{array}{l}\text { VES } \\
\text { NO }\end{array}$ & $4 / 4 / 90$ & 2 \\
\hline $\begin{array}{cc} \\
0 \\
\text { NOS }\end{array}$ & $4 / 4 / 90$ & 2 \\
\hline $\begin{array}{c}\text { YES } \\
\square \text { NO }\end{array}$ & $8 / 17 / 90$ & 8 \\
\hline ing & $4 / 4 / 90$ & 7 \\
\hline
\end{tabular}

WELL COVERS

well casing

(PREPACKAGED

(PREPACKAGED

(PREPACKAQED

(PREPACKAGED

(PREPACKAGED

MONITORING WELL PUMP

GROUT

SURFACE CASING

COMMENTS:

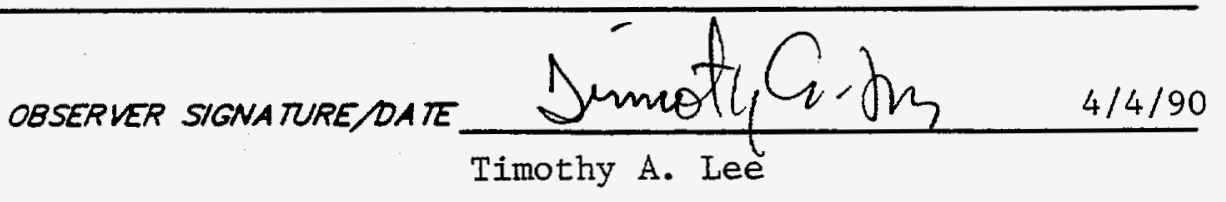


ERC / EDGE

Environmental

and Enerey

WELL NO. 960

\section{POST-MELL COMPLETION CHECKLIST}

\section{POST-WELL COMPLEMON TASKS}

COMPLIANCE

\section{DATE INITALS}

1. WUD SCRAPED FROW AUGERS SAMPLERS ANO ALL

$4 / 4 / 90$

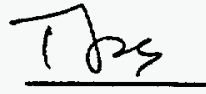
OTHER EOUIPWENT.

$4 / 4 / 90$

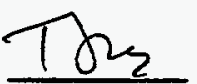

2. ALL WUD FRON RIG ANO EQUNPUENT SCRAPINGS ANO CUTTINGS DISPOSED OF IN ACCOROANCE WITH THE SPEOATCA IION PROMOED.

3 WEL DEVEZOPEO IN ACCOPOANCE WTH THE SPECHCA TON PROYOED ANO OETAKS OF THE DEVEZOPWENT ACTUTH RECOROED.

4. DRULNG STE PROPERLY CLEANED UP AFTER

$4 / 4 / 90$

$8 / 17 / 90$

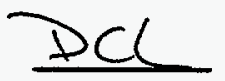
COMPLETON OF MEL INSTALLATION.

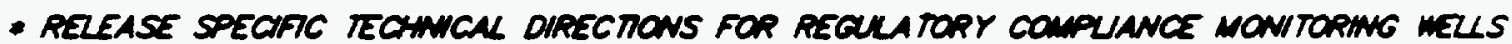
PHASE I. OAK RHDEE NA IIONAL LABORATOPY, OAK RMDEE M.O. K-4147, APAK 1987.

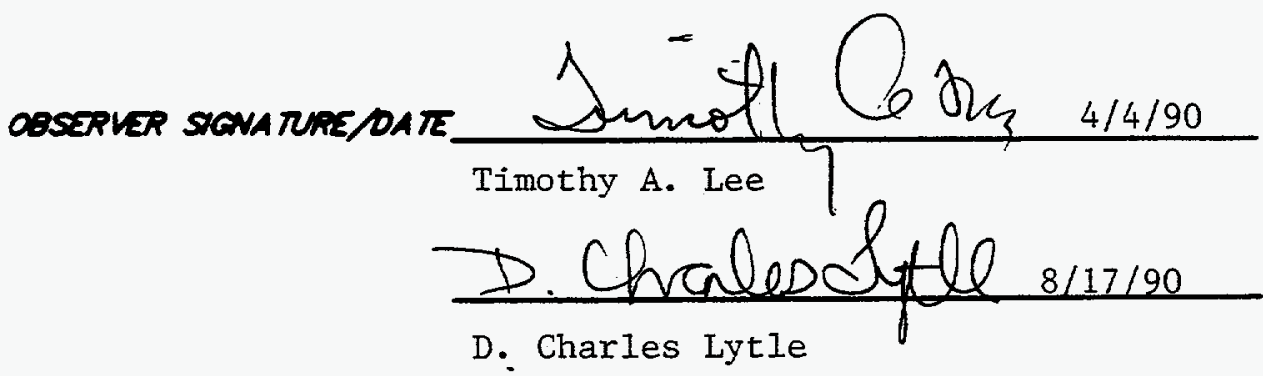




\section{MONITORING WELL \\ DEVELOPMENT FORM}

DEVELOPMENT DETAILS

METHOO OF

DEVELRMENT: Pumping with Geoguard pump

DEVELOPMENT

BEGAN DATE:

$8 / 13 / 90$

TME:

OEVELOPMENT

ENDING DATE:

$8 / 17 / 90$

DEVELOPMENT

OBSERVED BY:

D. Charles Lytle

ONE WELL VOLUNE: 11.1

GALLONS

TOTAL GALLONS PUMPED: 165 TOTAL WELL VOLUMES PUMPED: 14.8

INITAL PH: 8.9 FNAL PH: 8.5

INITAL CONOUCTVTY (KS/Cm): 567 FNAL CONOUCHUTY ( $\mathrm{HS} / \mathrm{cm}): 508$

OESCRIPTION OF INITAL TURBIOITY. Slight IY Cloudy

DESCRIPTION OF FNAL TURBIDITY Clear

FNAL MEASURED TURBIDITY:

$5.0 \mathrm{NTU}^{\prime} \mathrm{s}$

WELL APPROVED BY: R.C. Williams MMES

\begin{tabular}{|c|c|c|}
\hline $\begin{array}{l}O D O R \\
\text { OF MAIER. }\end{array}$ & None & \\
\hline $\begin{array}{l}\text { WATER } \\
\text { OISCHARGED } \\
\text { TO: }\end{array}$ & $\begin{array}{l}\text { 口 GROUND SURFACE } \\
\text { STORM SEMERS } \\
\text { DRUMS }\end{array}$ & $\begin{array}{l}\text { 口 TANK TRUCK } \\
\text { STORAGE TANKS } \\
\text { O OTHER }\end{array}$ \\
\hline
\end{tabular}

INITAL PRE-DEVELOPMENT

WATER DEPTH: 8.1 feet from ground surface

\section{DEVELOPMENT OBSERVATIONS}

observer sIGNATURE DATE D. Cha led ofte 8/17/90 


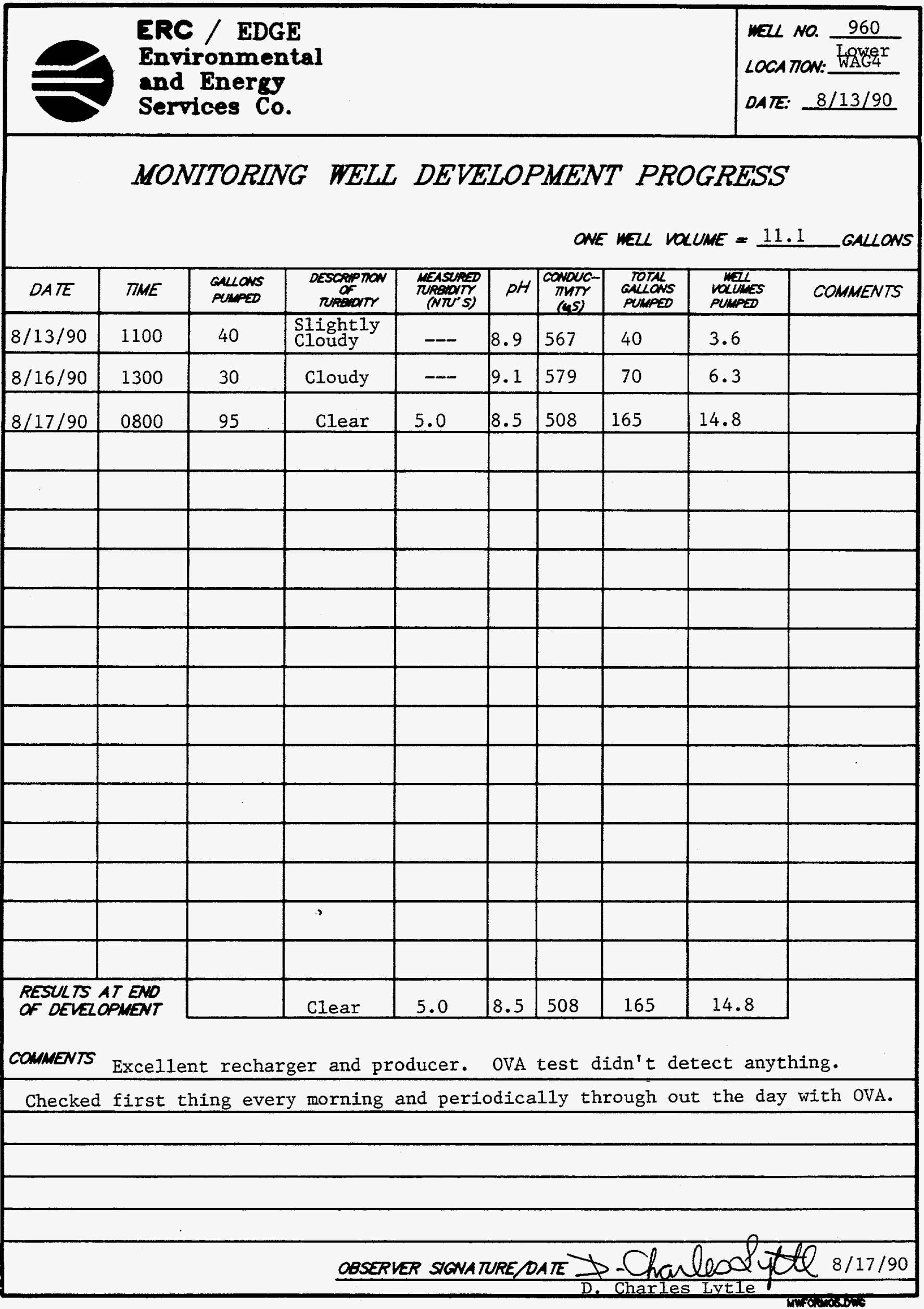




\section{HYDRAULIC CONDUCTIVTY CALCULATIONS}

PROGRAM SLUGT, VERSION 4.1, NOV. 1986

THIS PROGRAM CALCULATES MEAN TRANSMISSIVITIES FROM SLUG-TEST DATA BASED ON TWO ANALYTICAL APPROACHES :

(1) METHOD OF COOPER, BREDEHOEFT AND PAPADOPULOS, 1967 (ARTICLE IN VOI.3, NO.1 OF WRR ENTITLED

"RESPONSE OF A FINITE DIAMETER WELL TO AN INSTANTANEOUS CHARGE OF WATER")

(2) METHOD OF BOUWER AND RICE, 1976 (ARTICLE IN VOL. 12 , NO.3 OF WRR ENTITLED

"A SLUG TEST FOR DETERMINING HYDRAULIC CONDUCTIVITY OF UNCONFINED AQUIFERS WITH COMPLETELY OR PARTIALLY PENETRATING WELLS")

WELL NO.: 960

DATE OF TEST: $10-10-90$

PROJECT NO.: E221-002

CLIENT: MMES

SITE LOCATION : WAG-4

EDGE, INC. FIELD INVESTIGATOR: JAMES W. CARUTHERS

\section{INPUT DATA ARE:}

INNER CASING DIAMETER $=2.00$ INCHES

INNER SCREEN OR OPEN-HOLE DIAMETER $=2.00$ INCHES

DIAMETER OF DRILLED HOLE $=8.00$ INCHES

LENGTH OF SCREEN OR INTAKE PORTION $=15.00$ FEET

DEPTH FROM STATIC IEVEL TO BOTTOM OF SCREEN $=25.30$ FEET

THICKNESS OF SATURATED AQUIFER ZONE $=15.00 \mathrm{FEET}$

DEPTH TO STATIC WATER LEVEL BELOW REF. POINT $=1.00$ FEET

ESTIMATED POROSITY OF GRAVEL PACK $=.20$

FALLING-HEAD INDEX $=1$ ("I" IF FALLING, "O" IF RISING)

NUMBER OF DEPTH-TIME DATA POINTS = 32

HO WAS COMPUTED FROM INTERCEPT OF PLOT OF LOG(H) VS. TIME

SUCCESSIVE COMPUTED

VALUES FOR HO

(FEET)

3.0774

3.1179

PAGE 14 OF 17. 
ERC / EDGE

Environmental

and Energy

WELL NO.

960

\section{HYDRAULIC CONDUCTIVTY CALCULATIONS}

\begin{tabular}{|c|c|c|}
\hline$\left(\operatorname{SEC}^{\text {TIME }}\right)$ & $\begin{array}{l}\text { DEPTH TO WATER } \\
\text { (FEET) }\end{array}$ & $\begin{array}{l}\text { HEAD } \\
\text { (FEET) }\end{array}$ \\
\hline $\begin{array}{r}10.00 \\
20.00 \\
30.00 \\
40.00 \\
50.00 \\
60.00 \\
75.00 \\
90.00 \\
105.00 \\
120.00 \\
150.00 \\
180.00 \\
240.00 \\
300.00 \\
360.00 \\
420.00 \\
480.00\end{array}$ & $\begin{array}{l}4.820 \\
4.700 \\
4.600 \\
4.480 \\
4.390 \\
4.300 \\
4.190 \\
4.080 \\
3.970 \\
3.890 \\
3.690 \\
3.550 \\
3.270 \\
3.020 \\
2.850 \\
2.680 \\
2.560\end{array}$ & $\begin{array}{l}3.820 \\
3.700 \\
3.600 \\
3.480 \\
3.390 \\
3.300 \\
3.190 \\
3.080 \\
2.970 \\
2.890 \\
2.690 \\
2.550 \\
2.270 \\
2.020 \\
1.850 \\
1.680 \\
1.560\end{array}$ \\
\hline $\begin{array}{r}540.00 \\
600.00 \\
720.00 \\
840.00 \\
960.00 \\
1080.00 \\
1200.00 \\
1320.00 \\
1440.00 \\
1560.00 \\
1680.00 \\
1800.00 \\
1920.00 \\
2040.00 \\
2160.00\end{array}$ & $\begin{array}{l}2.440 \\
2.330 \\
2.150 \\
2.010 \\
1.890 \\
1.840 \\
1.740 \\
1.730 \\
1.630 \\
1.590 \\
1.550 \\
1.510 \\
1.470 \\
1.460 \\
1.430\end{array}$ & $\begin{array}{r}1.440 \\
1.330 \\
1.150 \\
1.010 \\
.890 \\
.840 \\
.740 \\
.730 \\
.630 \\
.590 \\
.550 \\
.510 \\
.470 \\
.460 \\
.430\end{array}$ \\
\hline
\end{tabular}


ERC / EDGE

Environmental

and Energy

Services Co.

\section{HYDRAULIC CONDUCTIVTY CALCULATIONS}

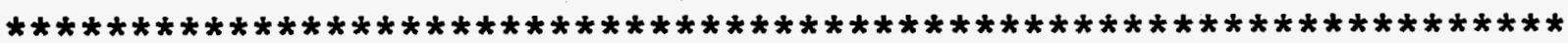
METHOD OF BOUWER AND RICE

COMPUTED RESULTS USING DIAMETER OF DRILLED HOLE:

$$
\text { PERMEABILITY }=8.06 \mathrm{E}-07 \mathrm{FT} / \mathrm{SEC}=2.46 \mathrm{E}-05 \mathrm{CM} / \mathrm{SEC}
$$

TRANSMISSIVITY $=1.21 \mathrm{E}-05 \mathrm{FT} * 2 / \mathrm{SEC}$

COMPUTED RESULTS USING DIAMETER OF CASING AND SCREEN:

$$
\text { PERMEABILITY }=1.10 \mathrm{E}-06 \mathrm{FT} / \mathrm{SEC}=3.35 \mathrm{E}-05 \mathrm{CM} / \mathrm{SEC}
$$

TRANSMISSIVITY $=1.65 \mathrm{E}-05 \mathrm{FT} * 2 / \mathrm{SEC}$ 


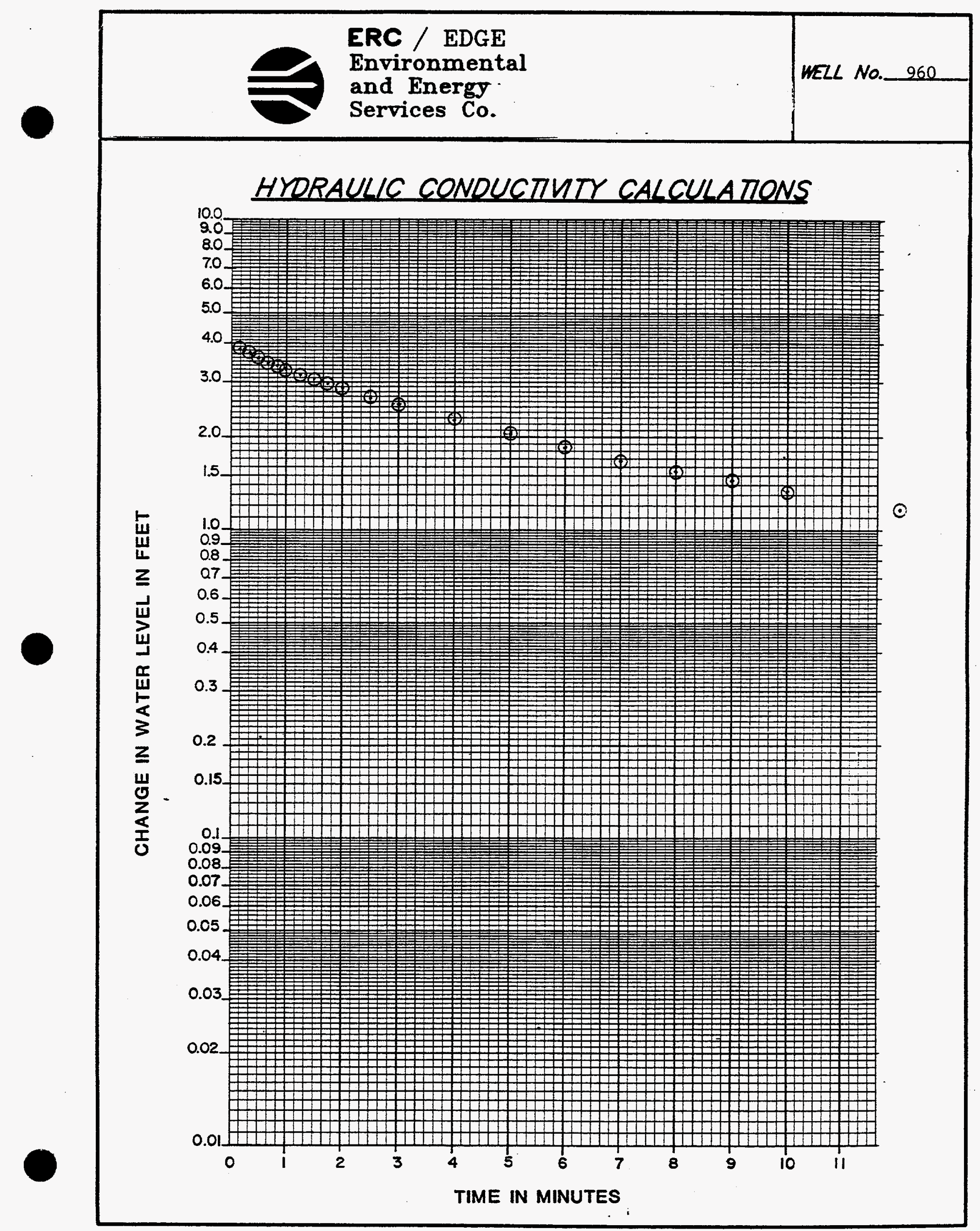




\subsection{General Information}

\subsection{Well Location}

Monitoring well number 961 is located in WAG 4. It is located along the southwest perimeter of WAG 4 approximately 500 feet west of Chemical waste Pit Number 6 . The location is shown on ORNL drawing number C3E20004A075. Survey coordinates for this well are $N$ 18,799.1817, $\mathrm{E}$ $27,371.3767(\mathrm{X}-10 \mathrm{grid})$ or latitude $35^{\circ}-54^{\prime}-49.11^{\prime \prime}$ and longitude $84^{\circ}-19^{\prime}-16.10^{\prime \prime}$. Coordinate data were provided by Martin Marietta Energy systems. The method used for conversion from $\mathrm{x}-10$ grid to Tennessee-Lambert state Plane Coordinates came from the publication "Tennessee Valley Authority Data Services Branch and Mapping Services Branch, Oak Ridge, Tennessee, DOE Plant Control, November 6, 1985, Field Book: Ess-3115, pp. 1-20." The latitude and longitude were calculated by Adams Craft Herz Walker Engineering, Inc., using methods from the U.S. Coast and Geodetic Survey Publication 62-4, "State Plane coordinates by Automatic Data Processing."

\subsection{Drilling Information}

Well number 961 was drilled by Geotek Engineering Company. $A$ Mobile B-50 and Ingersoll Rand T-4 rig were used to drill this boring for monitor well installation under the operation of Rick Herron and Larry Ledbetter with the assistance of James shelton and Fred Dixon. Drilling commenced on $9 / 26 / 89$ and was finished on 10/16/89. Paragraph 2.4.1 includes a detailed discussion of the well installation and a well schematic is included on the well installation/completion form. A synopsis of the drilling 
activity follows. This information was typed directly from field notes and was edited only when necessary for clarification.

9/26/89: The Mobile B-50 rig and tools were steam cleaned and mobilized to the staked location. The boring was split spooned and drilled with $\mathbf{8}^{\prime \prime}$ hollow stem augers from 0.0 to 15.17 feet and augered to 28.0 feet. No radiation was detected, so Carl stooksbury temporarily deregulated the boring to a class $I$. The boring was reamed with 22 -inch augers from 0.0 to 6.5 feet. Decontaminated and installed a 7.0 feet joint of 15 1/4-inch diverter casing.

10/3/89: The Ingersoll Rand $T-4$ and tools were steam cleaned and mobilized to the site.

10/4/89: The boring was drilled from 6.5 to 10.0 feet with 14-inch tricone and containment, changed to 14-inch augers and augered from 10.0 to 28.0 feet. Deepened boring from 28.0 to 33.0 feet with 14-inch tricone air rotary. Decontaminated 32.5 feet of 10 3/4-inch surface casing and ran in hole. Pulled rig off hole.

10/5/89: Grouting annulus of surface casing.

10/9/89: steam cleaned Ingersoll Rand $T-4$ and tools and mobilized to location. Deepened boring from 33.0 to 80.3 feet with 8 -inch tricone air rotary. Checked for water at 60 and 80 feet. Had 2 feet of water in 10 minutes at 60 and 4.5 feet of water in 10 feet at 80 feet.

10/10/89: Had 48 feet of water overnight. Blew boring clean and ran in 4-inch stainless steel casing and screen. Tremied in sandpack and installed 
ERC / EDGE

Environmental

and Enercy

Services Co.

MONTOAING MIL PROCRAN

IIIL OATA NAPRATVE

MIL Na. 961

bentonite seal above sandpack. Grouted annulus through 1-inch tremie pipe.

10/16/89: Well tested with "Go-No Go Gauge" and passed.

This well was logged by ERC Environmental and Energy Services Co. (ERC) hydrogeologists C. Allison Hodges and Michael $L$. Ebers. All well construction materials and supplies were from Martin Marietta Energy Systems approved batches. The batch origin of individual items is shown on the included Monitoring Well Materials Certification form.

2.0 Technical Information

\subsection{Decontamination Procedures}

The drilling rig, down hole tools, surface casing, stainless steel screen, stainless steel casing, centralizers, and stainless steel silt trap underwent the cleaning decontamination procedures outlined in the drilling specifications (Release specific Technical Directions for Regulatory Compliance Monitoring Wells Phase 1, Oak Ridge National Laboratory, Oak Ridge, W.O. K-4147, April 1987, pgs. 2-4). A checklist of the cleaned materials is included with this data package.

\subsection{8}

WAG 4 is located in Melton Valley which is in the valley and Ridge Physiographic Province of East Tennessee. WAG 4 is underlain by shale, siltstone, and limestone of the Middle to Upper Cambrian Conasauga Group. The Conasauga Group in the Oak Ridge area consists of six formations. They are, in ascending order, the Pumpkin Valley shale, 
Rutledge Limestone, Rogersville Shale, Maryville Limestone, Nolichucky Shale and the Maynardville Limestone. The Pumpkin Valley Shale and Rutledge Limestone underlie WAG 4. strike in and near WAG 4 ranges from N $85^{\circ} \mathrm{E}$ to $\mathrm{N} 15^{\circ} \mathrm{E}$ and dip varies from $27^{\circ}$ to vertical. These variations in strike and dip indicate that the conasauga has been deformed in the locale of WAG 4.

\section{3 sample Collection}

One soil/rock sample was collected during drilling, placed in an I-CHEM specialty cleaned glass container, sealed and submitted to Sample Receiving, Analytical Chemistry Division, Bldg. 4500s, ORNL. A chain of custody form for this sample is included with this data package. Soil sample 961501 was collected in the augered interval from 23.0 to 28.0 feet on $9 / 26 / 89$. A drill water sample was collected from the water pump on the drill rig on 10/9/89. Analytical results for the samples described above can be obtained from the Remedial Action Program data base at ORNL.

A bulk density soil sample was collected from the split spoon sample interval from 4.6 to 5.0 feet. The sample was measured and weighed, and a bulk density of $2.06 \mathrm{grams} / \mathrm{cm}^{3}$ was calculated.

The Ingersoll Rand $T-4$ compressed air was sampled with a cloth filter inserted between drill rods on 10/9/89. The sample was examined with an ultraviolet light for the pressure of hydrocarbons. The filter did not fluoresce. 


\subsection{Installation and Development}

\subsubsection{Installation}

This was a Type B well. A 22.0-inch diameter boring was augered from ground surface to 4.0 feet. A 15 1/4-inch diverter casing was installed from surface to 6.5 feet below ground surface and grouted in place. A 14-inch diameter boring was augered from 6.5 feet to 28.0 feet (auger refusal). The boring was then extended past the refusal depth with a 14-inch air rotary tricone roller bit from 28.0 feet to 33.0 feet. A 10 3/4-inch diameter string of decontaminated steel surface casing was installed from 0.0 feet to 32.5 feet, sealed with a 3.2 foot bentonite pellet layer from 53.3 feet to 56.5 feet, and tremie grouted in place. The surface casing minimizes potential cross contamination between the regolith and bedrock water bearing zones. After the surface casing was installed, the air rotary method was used to drill an 8-inch diameter boring to a total depth of 80.3 feet. A 4-inch diameter stainless steel screen with a silt trap/cap was installed from 60.0 feet to 80.3 feet. A 4-inch diameter stainless steel casing was installed from the top of the screen at 60.0 feet and extended 2.3 feet above ground surface. A sandpack was then tremied into the annular space from 80.3 feet up to 56.5 feet, with a 3.2-foot bentonite pellet seal poured into the annular space above the sandpack from 53.3 to 56.5 feet. The annular space from the top of the bentonite seal to the surface was tremie grouted with a cement/bentonite slurry. A detailed schematic of the well is included on the well installation/completion form. 


\section{4 .2 We11 Development}

Well number 961 was developed to remove drill cuttings, silt, and other fines. The monitoring well was developed using a Geoguard pump with an air compressor. All pumps were cleaned prior to use according to specified cleaning procedures (see Paragraph 2.1). The well was developed until a measured total of 490 gallons of water had been evacuated and the clarity of the discharge water was approved by the company representative. The final turbidity value measured at completion was 5.0 NTU's. A development form showing the exact method of development and other pertinent data is appended.

2.4.3 Installation of Dedicated Monitoring well Pump

After the well was developed, -a Geoguard Model No. 5614 dedicated monitoring well pump was installed on 8/17/90 at a depth of 78.8 feet below ground surface. These pumps are decontaminated at American Sigma and are sent prepackaged. A copy of the pump certification is kept on file at ORNL.

\subsection{Hydraulic Conductivity Testing}

Well number 961 was tested for the determination of hydraulic conductivity of the aquifer in the vicinity of the well screen. This was accomplished by instantaneously adding a known quantity of water to the monitoring well and measuring the recovery of the water level over time. The changing water levels were measured using a Druck 15 psi pressure transducer and an Omnidata Datapod II data recorder. The hydraulic conductivity value of $4.60 \times 10^{-6}$ $\mathrm{cm} / \mathrm{second}$ (shown as permeability on the hydraulic 


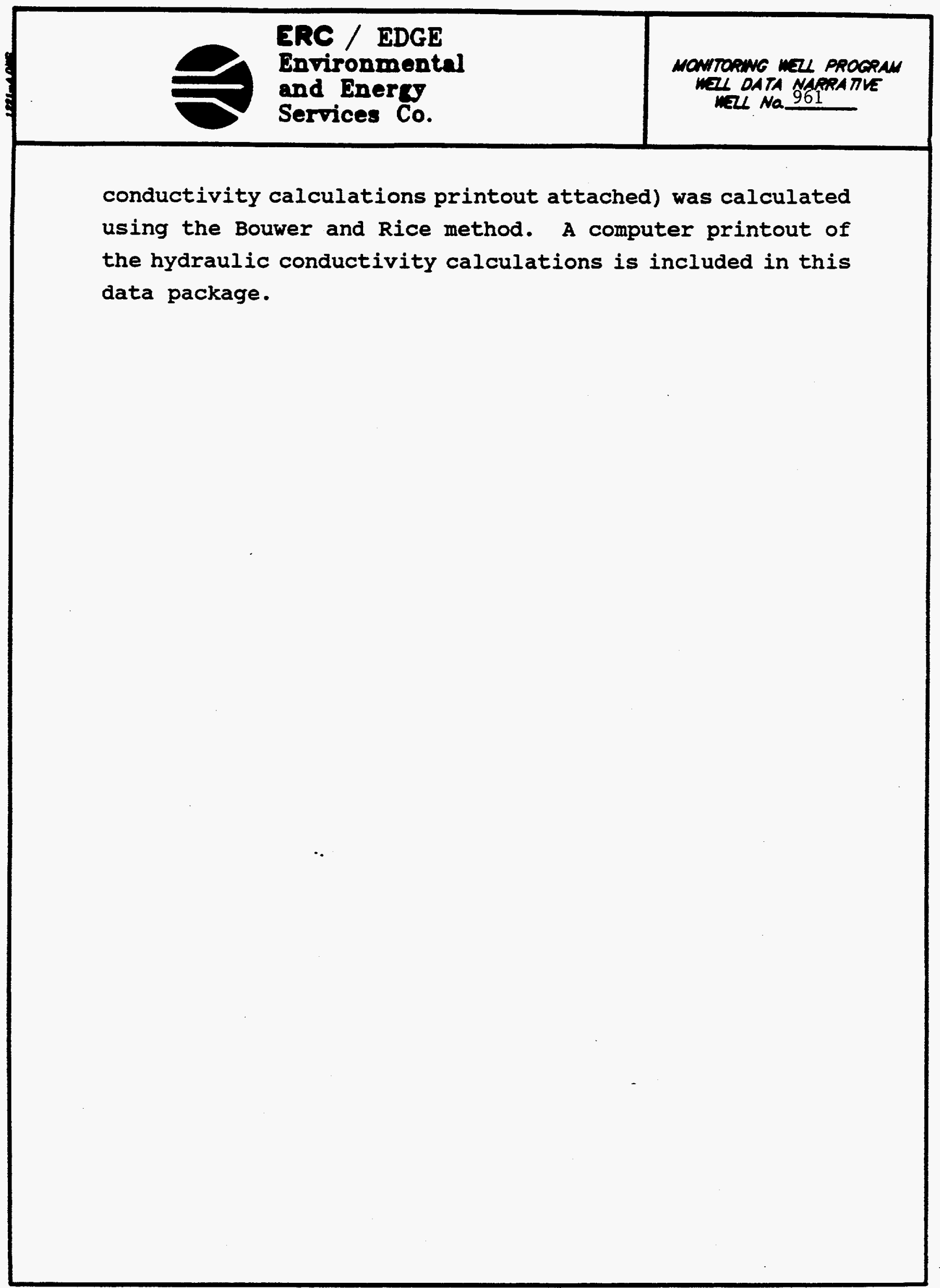

PACE 7 of 22 
ERC / EDGE

Environmental

and Enerey

WELL No. 961 Services Co.

\section{PRE-DRILLING CHECKLIST FOR MONITORING WELLS}

PRE-DRILLING TASKS

7. EXCAVATION PERMIT OBTAINED.

2. ALL EQUIPMENT HAS BEEN CLEANED BEFORE ORILLING.

30. SCREEN AND CASINGS HAVE BEEN WASHED, STEAMED, RINSED WIH DE-IONIZED OR OISTLLED WATER, RINSED WTH ISOPROPY ALCOHOL WRAPPED WTH PROTECTIE COVERING AND STORED OFF THE GROUND.

36. PRE-PACKAGED SCREENS, CASINGS AND CENTRALIZERS WERE USED.

4. WORK AREA FOR SAMPLE EXAMINA IION COVERED WTH CLEAN POL VETHRENE.

5. CLEAN KNIVES, QLOVES, SAMPLE JARS AND LABELS ON-HAND.

6. POL YETHIENE COVER IN PLACE OVER HOLE.
COMPLIANCE

DATE INITALS

9/26/89 CAH

9/26/89 CAH

$\mathrm{N} / \mathrm{A} \quad \mathrm{N} / \mathrm{A}$

10/10/89 MLE

9/26/89 $\mathrm{CAH}$

9/26/89 CAH

9/26/89 CAH

AOOITONAL NOTES/OBSERVATONS: 


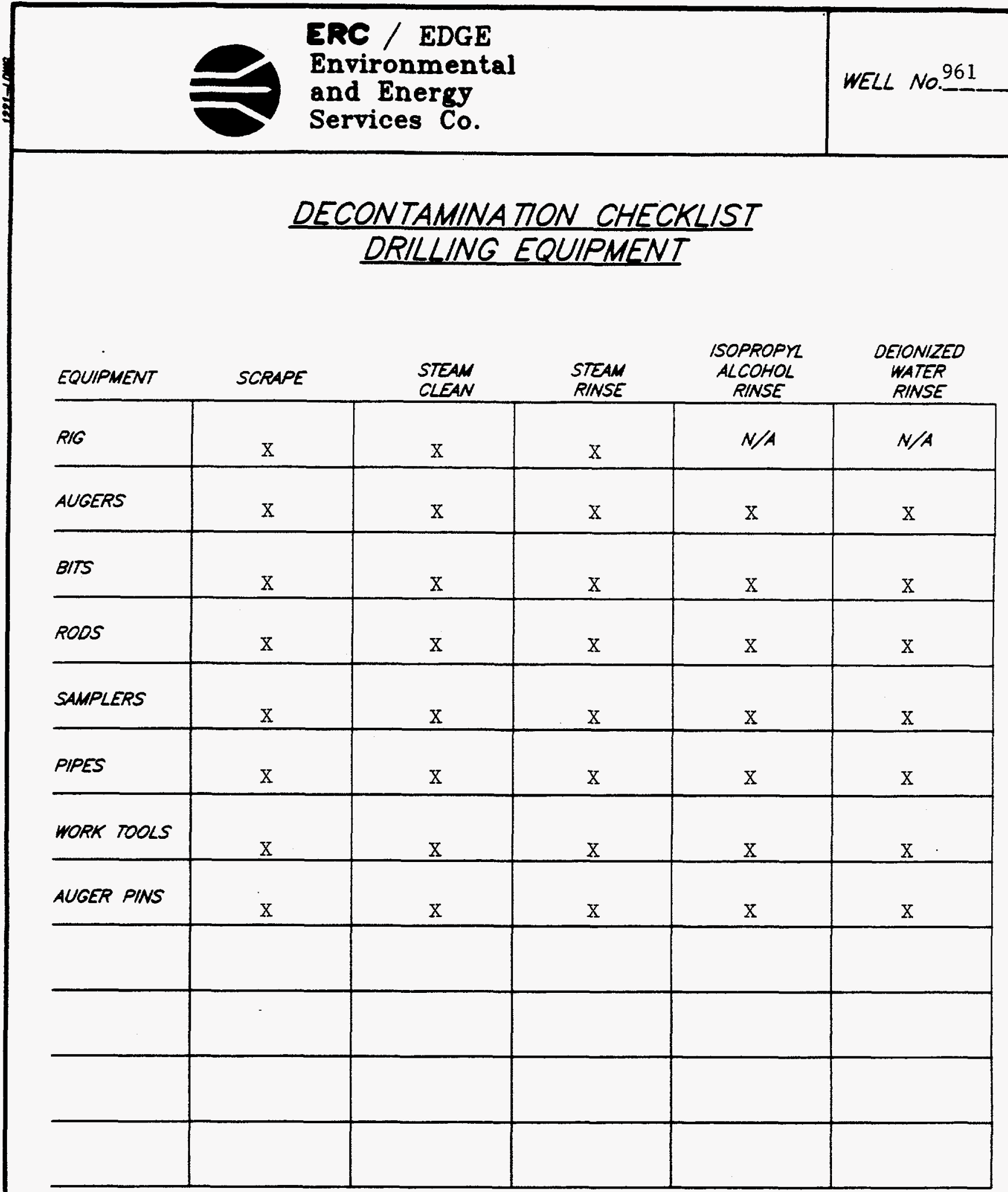

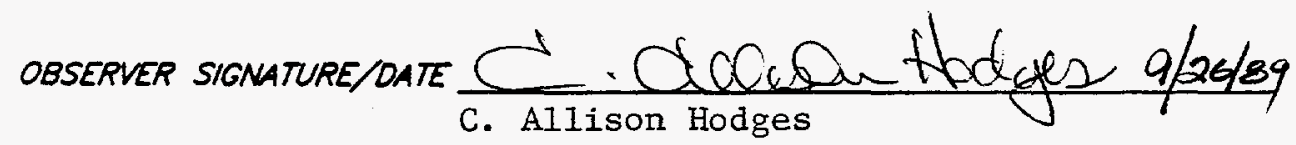




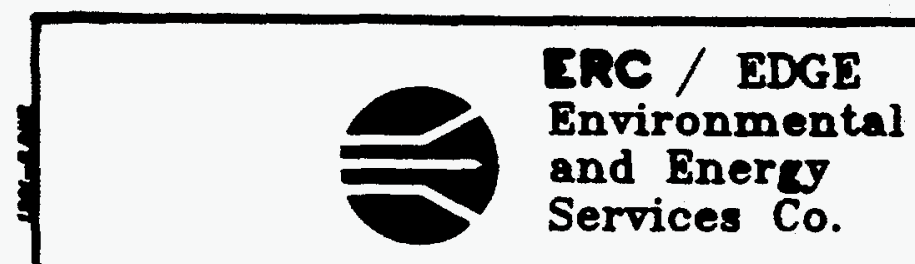

\section{ORNL MONITORING WELL LOG}

LOCA ION: WAG4

ORILLER: Rick Herron/Larry Ledbetter

HELPER: James Shelton/Fred Dixon

ORHL: Mobile B-50/Ingerso11 Rand $\mathrm{T}-4$

TPE ORILUNG: Split spoon, auger, Air rotary

No. SAMPLES TAKEN:_ One

CONTANMENT MPE: Plastic, auger pan, containment box

\begin{tabular}{|c|c|c|c|c|}
\hline \multirow{2}{*}{\multicolumn{4}{|c|}{$\begin{array}{l}\text { THIOXNESS OF SOLL (REFUSAL DEPTH): } \\
\text { DEPTH DRILLEO IN ROCK: } \\
\text { TOTAL OEPTH OF WELL. }\end{array}$}} & \multirow{2}{*}{$\begin{array}{l}\text { DRILUNG FLUID SAMPLES: } \\
\text { TPPE: Dri11 Water DATE: } 10 / 9 / 89 \\
\text { (961W01) }\end{array}$} \\
\hline & & & & \\
\hline \multicolumn{2}{|c|}{$\begin{array}{l}\text { OEPTH } \\
\text { (FEET) }\end{array}$} & $\begin{array}{l}\text { SAMPLE } \\
\text { INUMBER }\end{array}$ & $\begin{array}{l}\text { PERCENT } \\
\text { RECOVER Y }\end{array}$ & \multirow[t]{2}{*}{ SOL/BEDROCK DESCRIPTION } \\
\hline FRON & & & (SPUT SPOONS) & \\
\hline 0.0 & 2.0 & & & Gravel and clay \\
\hline \multirow[t]{4}{*}{2.0} & 3.7 & & $100 \%$ & Shale, light brown, moderate brown and pale \\
\hline & & & & olive, claylike, moist, highly weathered, \\
\hline & & 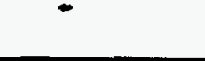 & & thinly laminated bedding, breaks at $45^{\circ}$ angle, \\
\hline & & & & silty, crumbly, dry \\
\hline 3.7 & 4.0 & & $100 \%$ & Shale, pale olive, sandy, micaceous \\
\hline \multirow[t]{2}{*}{4.0} & 4.4 & & $75 \%$ & Shale, very sandy, crumbly, dark yellowish \\
\hline & & & & orange, pale olive, micaceous \\
\hline \multirow[t]{5}{*}{4.4} & 5.0 & & & Shale, light brown, hard, layered, brittle, \\
\hline & & & & with pale olive and dusky yellow clay lenses, \\
\hline & & & & iron stained, with dark yellowish green and \\
\hline & & & & bright green silty to sandy, micaceous lenses \\
\hline & & & & Bulk density @ 4.6 to 5.0 feet $=2.06 \mathrm{~g} / \mathrm{cm}^{3}$ \\
\hline \multirow[t]{2}{*}{5.0} & 6.0 & & $100 \%$ & Shale, thinly laminated, grayish orange and \\
\hline & & & & dusky yellow, micaceous, dry \\
\hline \multirow[t]{4}{*}{6.0} & 8.5 & & $100 \%$ & Shale, mottled, dark yellowish orange, light \\
\hline & & & & brown with greenish gray to light gray lenses, \\
\hline & & & & bedded, crumbly, iron stained; silty, sandy \\
\hline & & & & micaceous, dry, grayish black lenses \\
\hline 8.5 & 9.8 & & $30 \%$ & Shale, mottled, dark yellowish orange and light \\
\hline
\end{tabular}

DATE: START: $9 / 26 / 89$

ANISH: $\frac{9 / 26 / 89}{10 / 10 / 89}$

LOGGE Br: Cichaelson Hodges

HEAL TH PHYSICST: Car1 Stooksbury
LUBRICANT TYPE: Green stuff

IPPE: Soil/rock

PAGE 1 of 2

inen stuff 


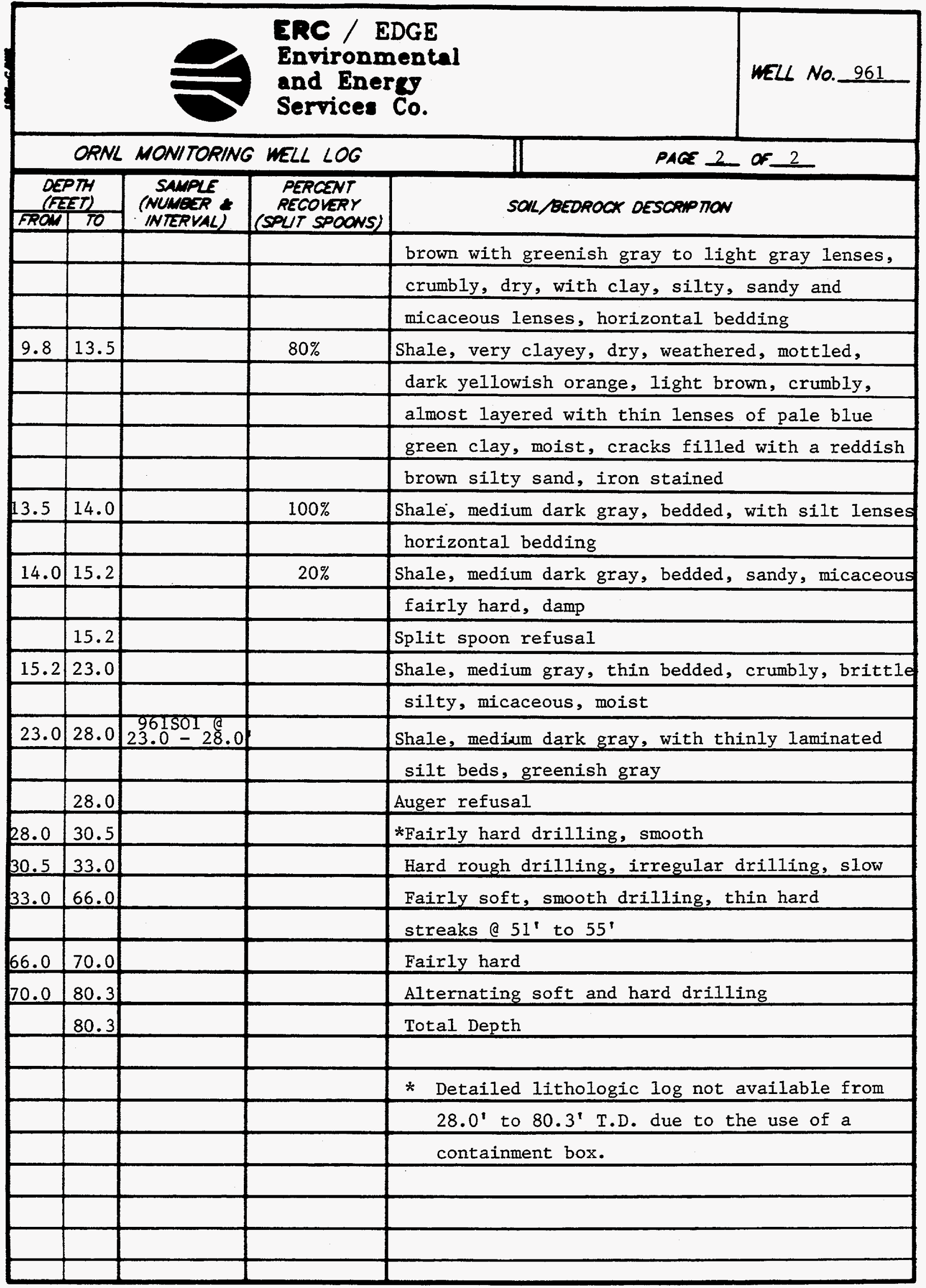




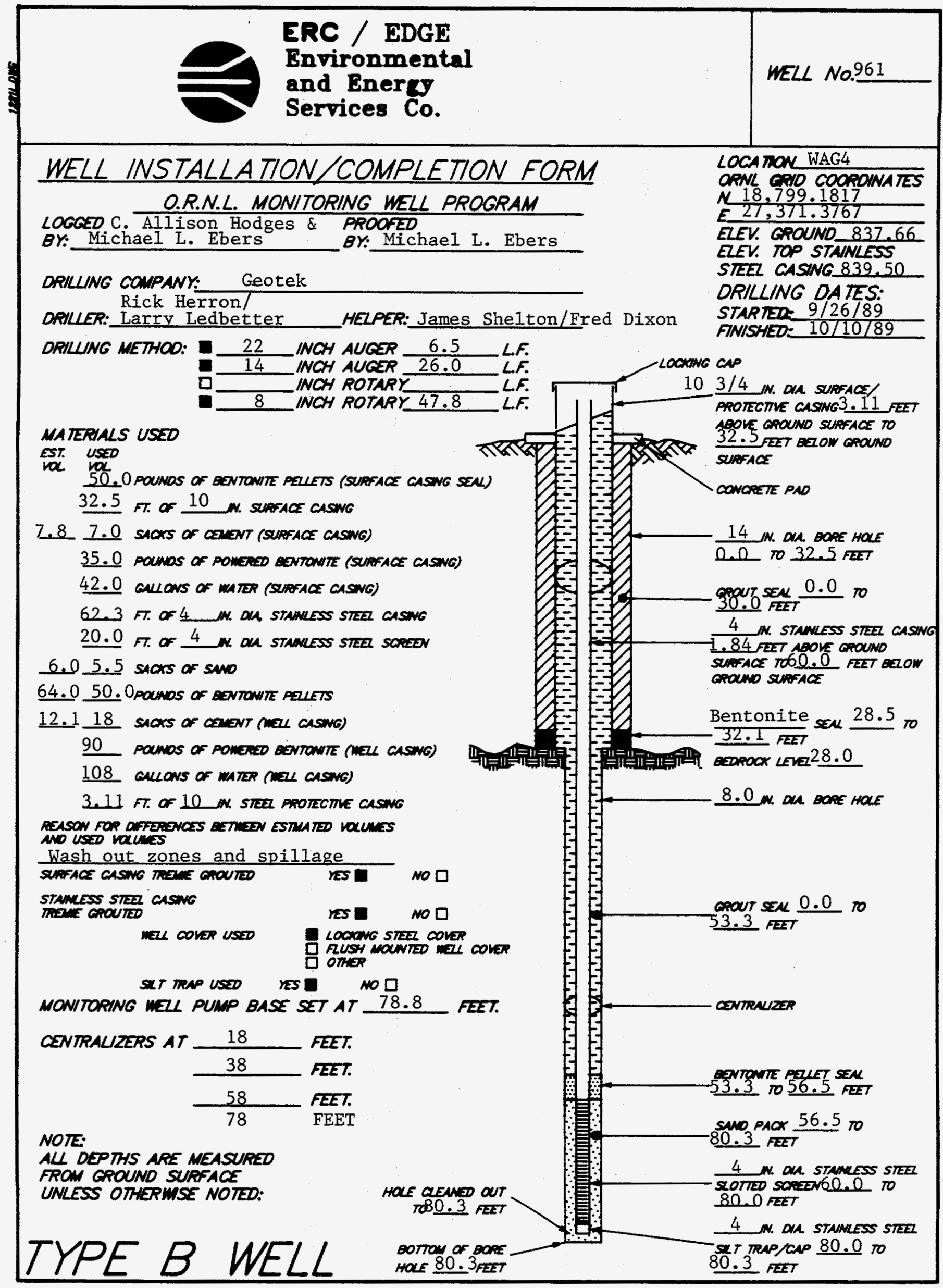

PACE 12 or 22 
ERC / EDGE

Environmental

WELL No. 961

and Energy

Services Co.

DATE: $10 / 10 / 89$

\section{MONITORING WELL MATERIALS CERTIFICATION}

\begin{tabular}{|c|c|c|}
\hline ITEM/MATERIAL & DATE USED & BATCH NUMBER \\
\hline SAND & $10 / 10 / 89$ & 1 \\
\hline BENTONITE & $10 / 10 / 89$ & MMES Stores \\
\hline (PREPACKAGED 口 $\left.\begin{array}{cc}\text { YES } \\
\text { NO }\end{array}\right)$ & $10 / 10 / 89$ & MMES Stores \\
\hline (PREPACKAGED 0 NOS & $10 / 10 / 89$ & MMES Stores \\
\hline STAINLESS STEEL CENTRALIZERS (PREPACKAGED 1 NES) & $10 / 10 / 89$ & MMES Stores \\
\hline (PREPACKAGED $\left.\begin{array}{c}\text { VES } \\
\text { NO }\end{array}\right)$ & $10 / 10 / 89$ & MMES Stores \\
\hline (PREPACKAGED 口 $\left.\begin{array}{c}\text { YES } \\
\text { NO }\end{array}\right)$ & $6 / 7 / 90$ & 8 \\
\hline \multirow{2}{*}{ GROUT } & $10 / 5 / 89$ & 1 \\
\hline & $10 / 10 / 89$ & 2 \\
\hline \multicolumn{3}{|l|}{ WELL COVERS } \\
\hline SURFACE CASING & $10 / 4 / 89$ & 1 \\
\hline
\end{tabular}

COMMENTS:

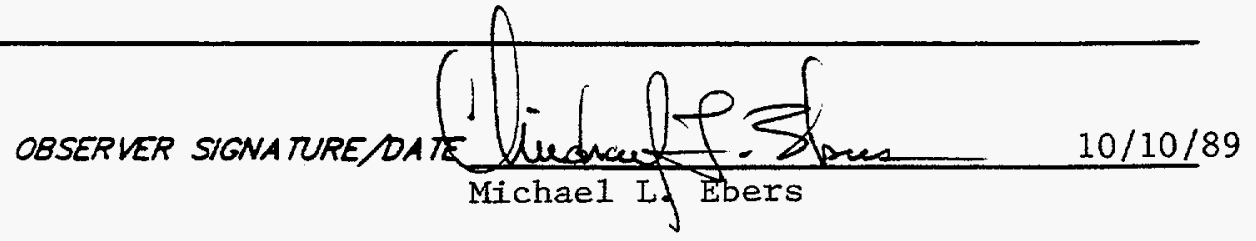

PAGE 13 OF 22. 


\begin{tabular}{|c|c|}
\hline $\begin{array}{l}\text { ERC / EDGE } \\
\text { Environmental } \\
\text { and EnergJ } \\
\text { Services Co. }\end{array}$ & wELL No. 961 \\
\hline$\frac{\text { POST-WELL COMPLEMON }}{\text { CHECKLIST }}$
\end{tabular}

\section{POST-WELL COMPLETION TASKS}

1. WO SCRAPEO FROM AUGERS SAMPLERS ANO ALL OTHER EOUIPWENT.

2. ALL WUD FRON RG ANO EQUIPUENT SORAPWOS WN CUTINES OISPOSED OF IN ACCORDANCE WTH THE SPECATCA ION PROWDED.

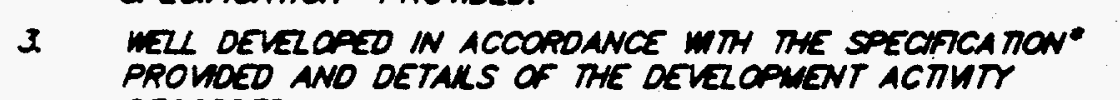
RECORDED.

4. DRULNG STE PROPERLY CLEANDD UP AFTER cOMPLETION of MZL INSTALUTION.

$$
\begin{aligned}
& \text { COMPLIANCE } \\
& \text { DA.E INITALS }
\end{aligned}
$$$$
\text { 10/10/89 NAE }
$$$$
\text { 10/10/89 MUE }
$$$$
6 / 7 / 90
$$

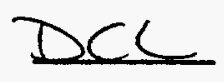

$10 / 11 / 89$

NLE

commemon ar mazl mstalliman.

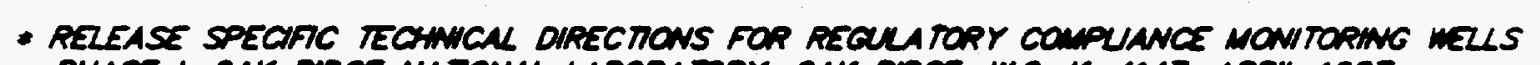

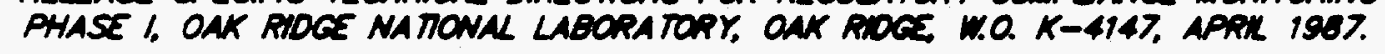

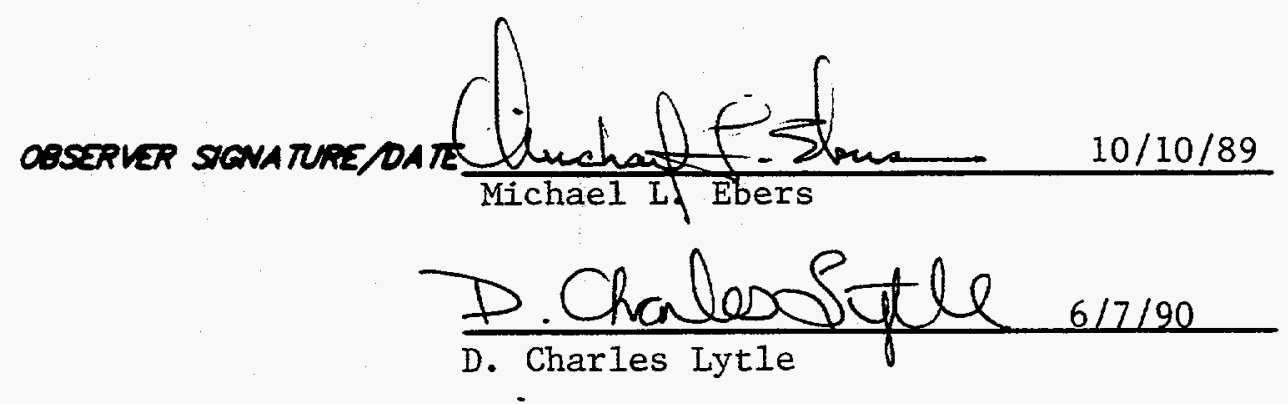


ERCE

Environmental

and Energy

WELL No. 961

Services Co.

\section{MONITORING WELL \\ DEVELOPMENT FORM}

DEVELOPMENT DETAILS

METHOO OF

QEVELOPMENT: Surging and pumping

DEVELOPMENT

BEGAN DATE:

$5 / 25 / 90$

TME:

OEVELOPMENT

ENDING DATE:

$6 / 7 / 90$

DEVELOPMENT

OBSERVED BY:

D. Charles Lytle

ONE WELL VOLUME: 57.0 GALLONS

TOTAL GALLONS PUMPED: 490

TOTAL WEL VOLUMES PUMPED: 8.6

INITAL $\rho H:$ : 7.9

FNNAL PH: 8.4

INITAL CONDUCTUTY ( $\mathrm{KS} / \mathrm{cm}): 500$

FINAL CONOUCTUTH $(\mathrm{\mu s} / \mathrm{cm}): 510$

DESCRIPTION OF INITAL RURBIDITY:_Cloudy

OESCRIPTION OF FINAL TURBIDITY:___ Clear

FNAL MEASURED TURBIDITY:

$5.0 \mathrm{NTU}^{\prime} \mathrm{s}$

WEL APPROVED BY: R.C. Williams MMES

OOOR

OE MATER:

WATER

OISCHARGEO None

TO:

GROUNO SURFACE
DTORM SEWERS
D ORUNS

TANK RRUCK

口 STORAGE TANKS

D OTHER

\section{INITAL PRE-DEVELOPNENT}

WATER DEPTH: $\quad 17.8$ feet from ground surface

\section{DEVELOPMENT OBSERVATONS}




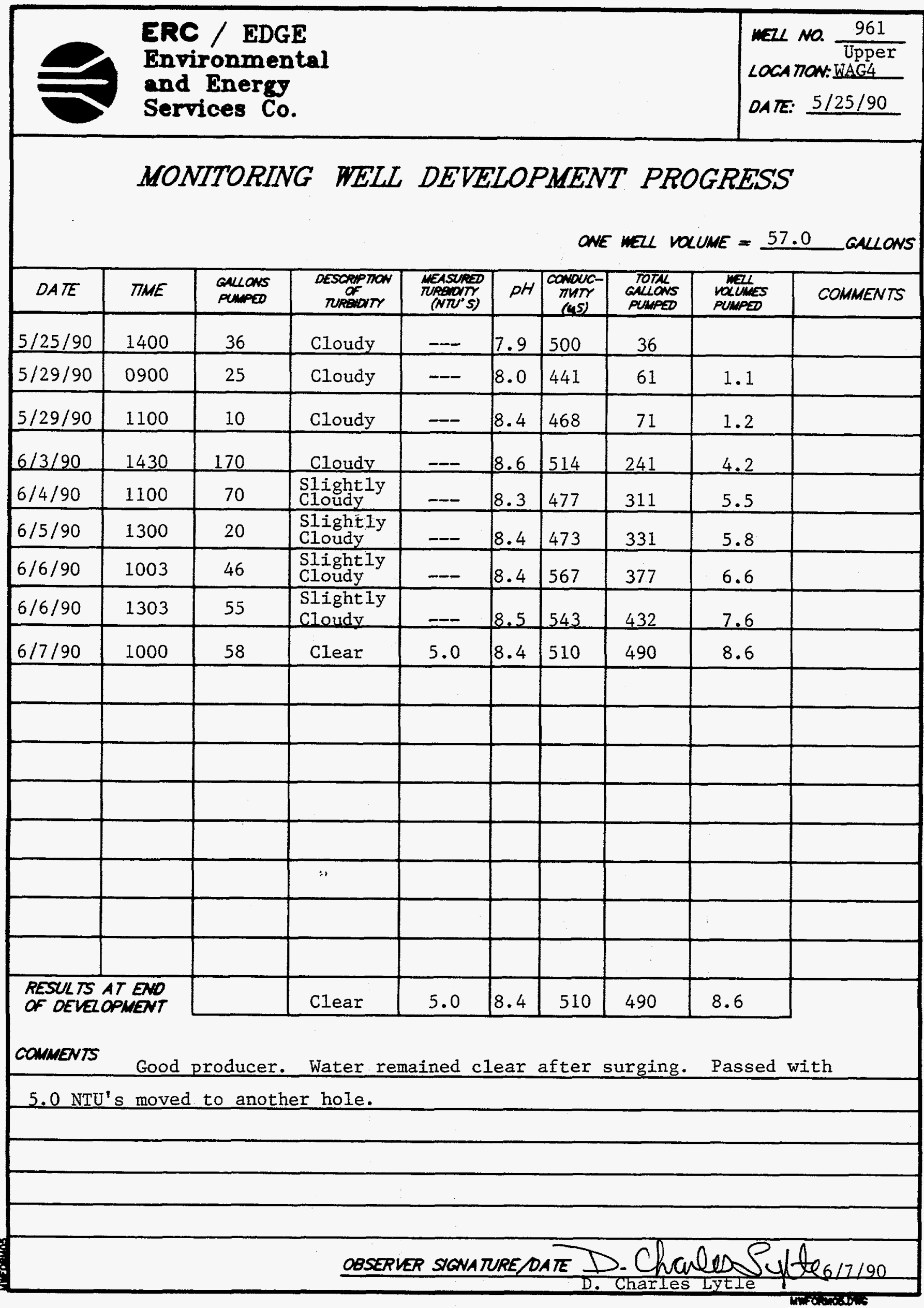

PACE 16 of 22 . 


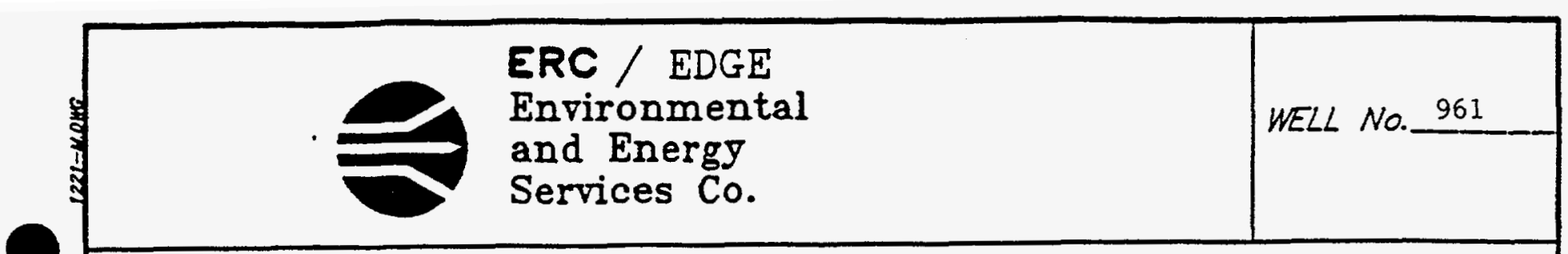

HYDRAULIC CONDUCTIVTY CALCULATIONS

PROGRAM SLUGT, VERSION 4.1, NOV. 1986

THIS PROGRAM CALCULATES MEAN TRANSMISSIVITIES FROM SLUG-TEST DATA BASED ON TWO ANALYTICAL APPROACHES:

(I) METHOD OF COOPER, BREDEHOEFT AND PAPADOPULOS, 1967 (ARTICLE IN VOL.3, NO.I OF WRR ENTITLED "RESPONSE OF A FINITE DIAMETER WELL TO AN INSTANTANEOUS CHARGE OF WATER")

(2) METHOD OF BOUWER AND RICE, 1976 (ARTICLE IN VOL. 12, NO.3 OF WRR ENTITLED

"A SLUG TEST FOR DETERMINING HYDRAULIC CONDUCTIVITY OF UNCONFINED AQUIFERS WITH COMPLETELY OR PARTIALLY PENETRATING WELIS")

WELI NO.: 961

PROJECT NO.: E221-002
DATE OF TEST: $10-30-90$

CLIENT: MMES

SITE LOCATION: WAG-4

EDGE, INC. FIELD INVESTIGATOR: JAMES W. CARUTHERS

INPUT DATA ARE:

INNER CASING DIAMETER $=4.00$ INCHES

INNER SCREEN OR OPEN-HOLE DIAMETER $=4.00$ INCHES

DIAMETER OF DRILLED HOLE $=8.00$ INCHES

IENGTH OF SCREEN OR INTAKE PORTION $=20.00$ FEET

DEPTH FROM STATIC LEVEL TO BOTTOM OF SCREEN $=60.00$ FEET

THICKNESS OF SATURATED AQUIFER ZONE $=20.00$ FEET

DEPTH TO STATIC WATER LEVEL BELOW REF. POINT $=1.00$ FEET

ESTIMATED POROSITY OF GRAVEL PACK $=.20$

FALLING-HEAD INDEX = 1 ("I" IF FALLING,"O" IF RISING)

NUMBER OF DEPTH-TIME DATA POINTS $=32$

HO WAS COMPUTED FROM INTERCEPT OF PLOT OF LOG(H) VS. TIME

\section{SUCCESSIVE COMPUTED \\ VALUES FOR HO}

(FEET)

2.7082

2.7092 


\begin{tabular}{|c|c|c|}
\hline$\left(\mathrm{SEC}^{\text {TIME }}\right)$ & $\begin{array}{l}\text { DEPTH TO WATER } \\
\text { (FEET) }\end{array}$ & $\begin{array}{l}\text { HEAD } \\
\text { (FEET) }\end{array}$ \\
\hline $\begin{array}{r}10.00 \\
20.00 \\
30.00 \\
40.00 \\
50.00 \\
60.00 \\
75.00 \\
90.00 \\
105.00 \\
120.00 \\
150.00 \\
180.00 \\
240.00 \\
300.00 \\
360.00 \\
420.00 \\
480.00\end{array}$ & $\begin{array}{l}3.750 \\
3.750 \\
3.750 \\
3.710 \\
3.710 \\
3.700 \\
3.700 \\
3.700 \\
3.680 \\
3.680 \\
3.680 \\
3.670 \\
3.650 \\
3.650 \\
3.650 \\
3.630 \\
3.630\end{array}$ & $\begin{array}{l}2.750 \\
2.750 \\
2.750 \\
2.710 \\
2.710 \\
2.700 \\
2.700 \\
2.700 \\
2.680 \\
2.680 \\
2.680 \\
2.670 \\
2.650 \\
2.650 \\
2.650 \\
2.630 \\
2.630\end{array}$ \\
\hline $\begin{array}{r}540.00 \\
600.00 \\
720.00 \\
840.00 \\
960.00 \\
1080.00 \\
1200.00 \\
1320.00 \\
1440.00 \\
1560.00 \\
1680.00 \\
1800.00 \\
1920.00 \\
2040.00 \\
2160.00\end{array}$ & $\begin{array}{l}3.630 \\
3.590 \\
3.570 \\
3.560 \\
3.530 \\
3.530 \\
3.530 \\
3.530 \\
3.510 \\
3.510 \\
3.480 \\
3.450 \\
3.420 \\
3.420 \\
3.420\end{array}$ & $\begin{array}{l}2.630 \\
2.590 \\
2.570 \\
2.560 \\
2.530 \\
2.530 \\
2.530 \\
2.530 \\
2.510 \\
2.510 \\
2.480 \\
2.450 \\
2.420 \\
2.420 \\
2.420\end{array}$ \\
\hline
\end{tabular}




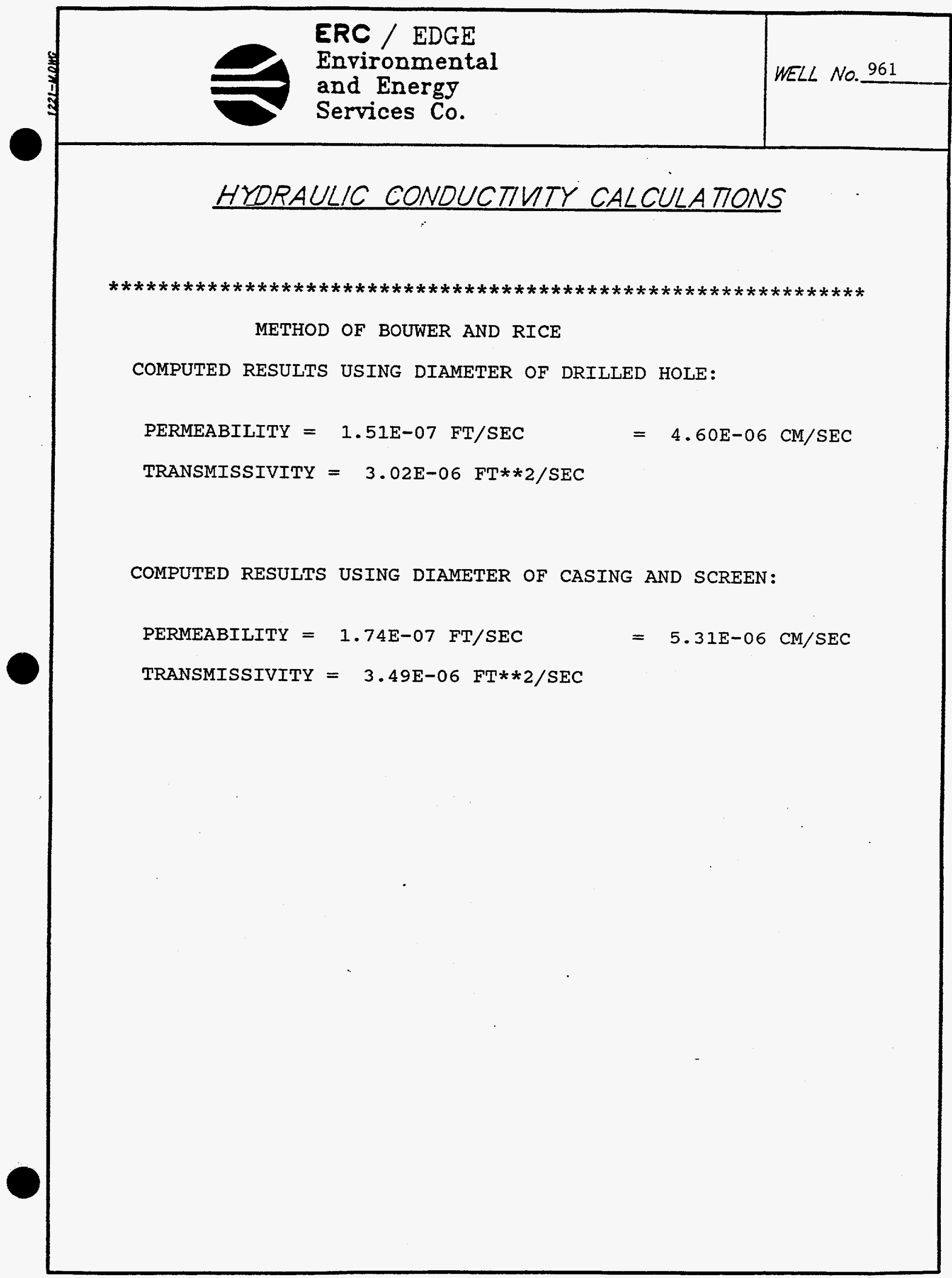


ERC / EDGE

Environmental

and Energy

WELL No. 961

Services Co.

\section{HYORAULIC CONDUCTIUTY CALCULATIONS}

10.0

9.0

8.0

6.0

5.0

4.0

3.

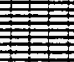

1

11
111

1

1

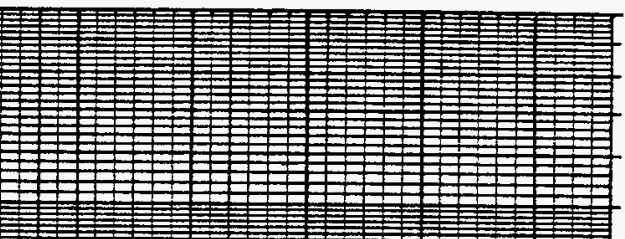

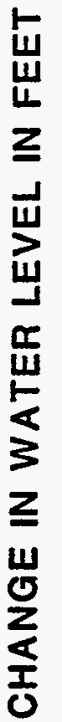

1.5

-

1

W

(1)

-

0.9

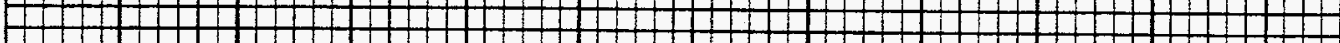

0.9

$\geq \quad 07$

$\quad 0.5$

0.4

0.3

0.2

0.15

-

O.

0.09

0.08

0.07

0.06 1.05
Y

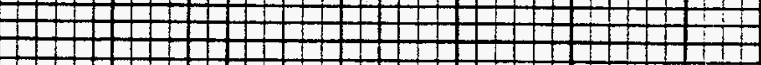

I

\begin{tabular}{l} 
O.04 \\
Y. \\
\hline
\end{tabular}

0.02

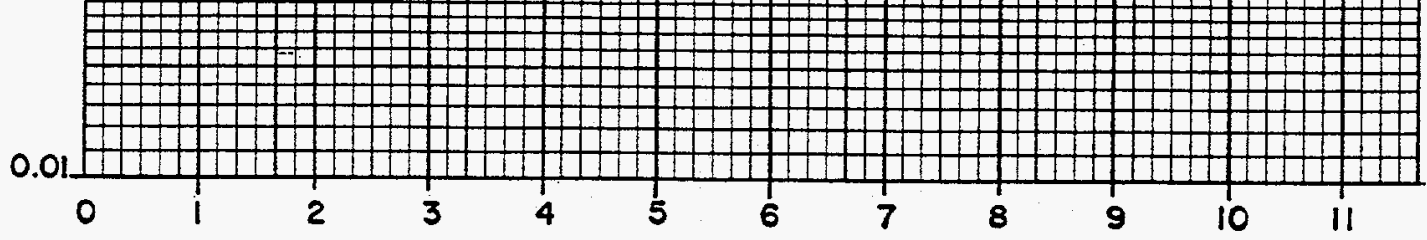

TIME IN MINUTES 


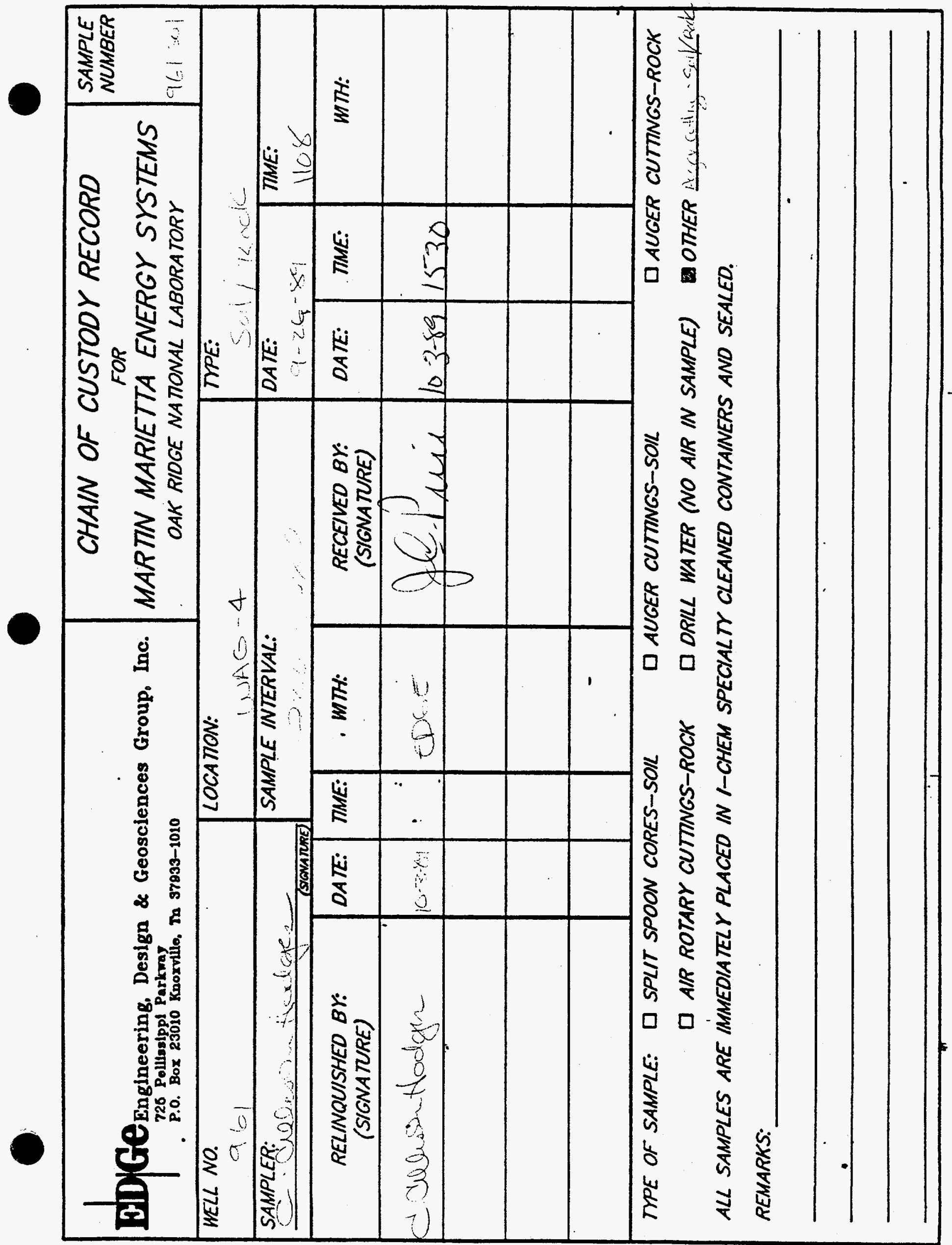




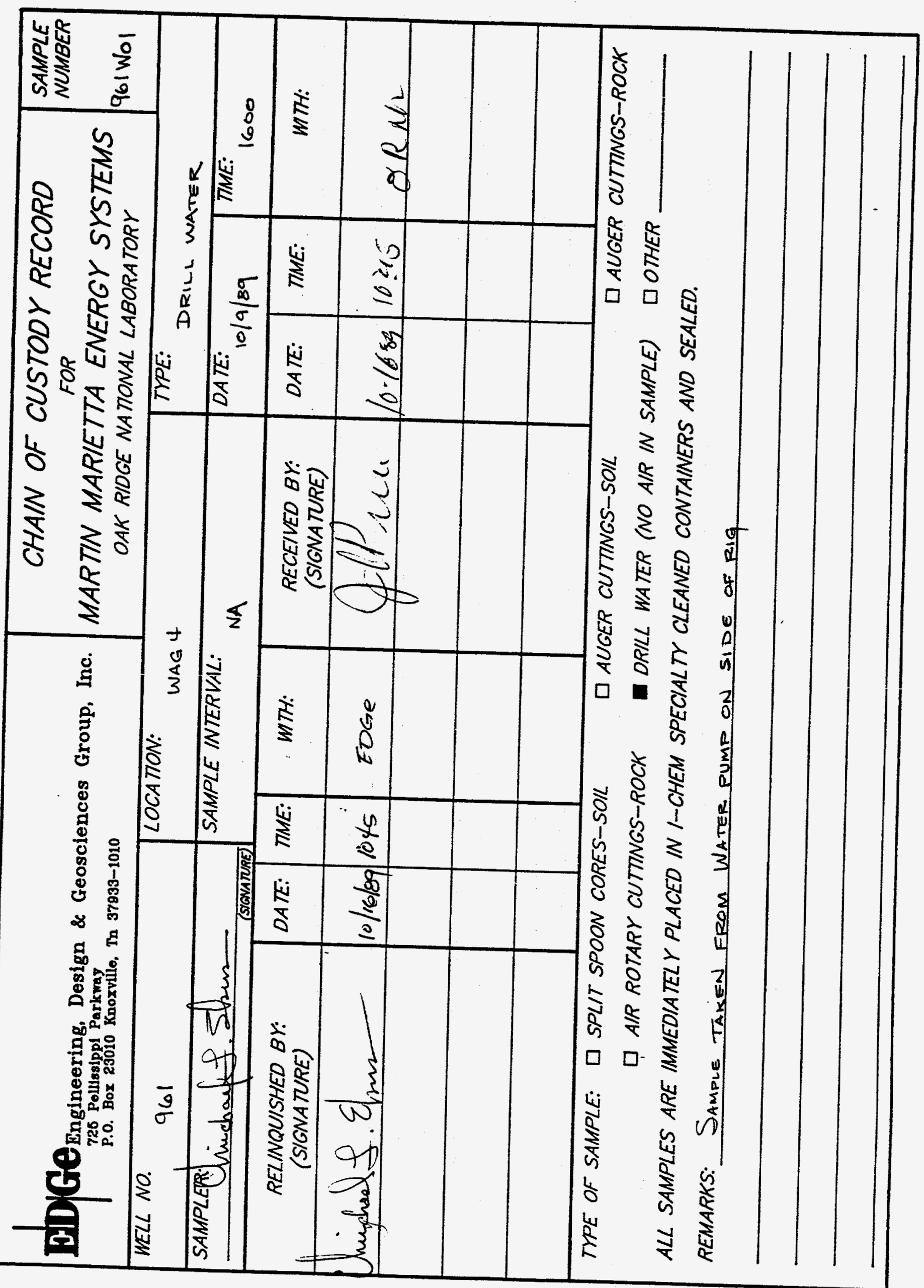




\subsection{General Information}

\subsection{Well Location}

Monitoring well number 962 is located in WAG 4. It is located along the southwest perimeter of WAG 4 approximately 500 feet west of chemical Waste Pit Number 6 . The location is shown on ORNL drawing number C3E20004A075 Survey coordinates for this well are $N 18,809.0525, E$ $27,387.5223$ (X-10 grid) or latitude $35^{\circ}-54^{\prime}-49.28^{\prime \prime}$ and longitude $84^{\circ}-19^{\prime}-16.00^{\prime \prime}$. Coordinate data were provided by Martin Marietta Energy systems. The method used for conversion from X-10 grid to Tennessee-Lambert State Plane Coordinates came from the publication "Tennessee Valley Authority Data Services Branch and Mapping Services Branch, Oak Ridge, Tennessee, DOE Plant Control, November 6, 1985, Field Book: ESS-3115, pp. 1-20." The latitude and longitude were calculated by Adams Craft Herz Walker Engineering, Inc., using methods from the U.S. Coast and Geodetic Survey Publication 62-4, "State Plane Coordinates by Automatic Data Processing."

\subsection{Drilling Information}

Well number 962 was drilled by Geotek Engineering Company. A Mobile B-50 rig was used to drill this boring for monitor well installation under the operation of Rick Herron with the assistance of Fred Dixon. Drilling commenced on $10 / 11 / 89$ and was finished on 10/11/89. Paragraph 2.4.1 includes a detailed discussion of the well installation and 
a well schematic is included on the well installation/ completion form. A synopsis of the drilling activity follows. This information was typed directly from field notes and was edited only when necessary for clarification.

10/11/89: The Mobile B-50 auger rig and tools were steam cleaned and mobilized to the staked location. The boring was augered from 0.0 to 37.7 feet with 8-inch hollow stem augers. Water was encountered at 30 feet. The boring was bailed dry to remove the cuttings and mud. Two inch stainless steel screen and casing were installed. The sandpack was tremied in place and a bentonite seal was placed above the sand. The annulus was grouted to the surface.

This well was logged by ERC Environmental and Energy Services Co. (ERC) hydrogeologist Michael L. Ebers. All well construction materials and supplies were from Martin Marietta Energy Systems approved batches. The batch origin of individual items is shown on the included Monitoring Well Materials Certification form.

\subsection{Technical Information}

\subsection{Decontamination Procedures}

The drilling rig, down hole tools, surface casing, stainless steel screen, stainless steel casing, centralizers, and stainless steel silt trap underwent the cleaning decontamination procedures outlined in the drilling specifications (Release specific Technical Directions for Regulatory Compliance Monitoring Wells 
Phase 1, Oak Ridge National Laboratory, Oak Ridge, W.0. K-4147, April 1987, pgs. 2-4). A checklist of the cleaned materials is included with this data package.

\subsection{Geology}

WAG 4 is located in Melton Valley which is in the Valley and Ridge Physiographic Province of East Tennessee. WAG 4 is underlain by shale, siltstone, and limestone of the Middle to Upper Cambrian Conasauga Group. The Conasauga Group in the Oak Ridge area consists of six formations. They are, in ascending order, the Pumpkin Valley Shale, Rutledge Iimestone, Rogersville Shale, Maryville Limestone, Nolichucky Shale and the Maynardville Limestone. The Pumpkin Valley Shale and Rutledge Limestone underlie WAG 4. strike in and near WAG 4 ranges from $N 85^{\circ} \mathrm{E}$ to $\mathrm{N} 15^{\circ} \mathrm{E}$ and dip varies from $27^{\circ}$ to vertical. These variations in strike and dip indicate that the conasauga has been deformed in the locale of WAG 4.

\section{3 sample collection}

No samples were collected during drilling.

\subsection{Installation and Development}

\subsubsection{Installation}

This was a Type A well. A 2-inch diameter stainless steel silt trap was installed from 36.94 to 37.18 feet. Above the silt trap a 2-inch diameter stainless steel screen was installed from 26.6 to 36.94 feet. A 2-inch diameter stainless steel casing was installed above the screen from 
26.6 feet to 2.3 feet above ground surface. A sandpack was then poured into the annular space from 37.18 feet up to 25.2 feet, with a 2.5-foot bentonite pellet seal poured into the annular space above the sandpack from 22.7 to 25.2 feet. The annular space from the top of the bentonite seal to the surface was tremie-grouted with a cement/bentonite slurry. A detailed schematic of the well is included on the well installation/completion form.

\section{4 .2 Well Development}

Well number 962 was developed to remove drill cuttings, silt, and other fines. The monitoring well was developed using a Geoguard pump with an air compressor. All pumps were cleaned prior to use according to specified cleaning procedures (see Paragraph 2.1). The well was developed until a measured total of 790 gallons of water had been evacuated and the clarity of the discharge water was approved by the company representative. The final turbidity value measured at completion was 2.0 NTU's. A development form showing the exact method of development and other pertinent data is appended.

\subsubsection{Installation of Dedicated Monitoring We11 Pump}

After the well was developed, a Geoguard Model No. 5614 dedicated monitoring well pump was installed on 6/14/90 at a depth of 34.5 feet below ground surface- These pumps are decontaminated at American Sigma and are sent prepackaged. A copy of the pump certification is kept on file at ORNL. 
ERC / EDGE

Environmental

and Eneres

Services Co.
MONITORWG MZL PROCRAM

WII DATA NAGRATVE

जI $\mathrm{Na} 962$

\subsection{Hydraulic Conductivity Testing}

Well number 962 was tested for the determination of hydraulic conductivity of the aquifer in the vicinity of the well screen. This was accomplished by instantaneously adding a known quantity of water to the monitoring well and measuring the recovery of the water level over time. The changing water levels were measured using a Druck 15 psi pressure transducer and an Omnidata Datapod II data recorder. The hydraulic conductivity value of $4.74 \times 10^{-5}$ $\mathrm{cm} / \mathrm{second}$ (shown as permeability on the hydraulic conductivity calculations printout attached) was calculated using the Bouwer and Rice method. A computer printout of the hydraulic conductivity calculations is included in this data package. 
ERC / EDGE

Environmental

and Energy

WELL NO

Services Co.

\section{PRE-DRILLING CHECKLIST FOR MONITORING WELLS}

\section{PRE-DRILLING TASKS}

1. EXCAVATION PERMIT OBTAINED.

2. ALL EQUIPMENT HAS BEEN CLEANED BEFORE DRILLNG.

30. SCREEN AND CASNGS HAVE BEEN WASHED, STEAMED, RINSED WTH DE-IONIZED OR DISTLLED WATER. RINSED WIH ISOPROPH ALCOHOL MRAPPED WTH PROTECTIE COVERING AND STORED OFF THE GROUND.

36. PRE-PACKAGED SCREENS, CASINGS AND CENTRALIZERS WERE USEO.

4. WORK AREA FOR SAMPLE EXAMINATION COVERED WTH CLEAN POC TETHRENE.

5. CLEAN KNIVES, GOVES, SAMPLE JARS AND LABEZS ON-HAND.

6. POL YETHRENE COVER IN PLACE OVER HOLE.

ADOIMONAL NOTES/OBSERVA MONS:
COMPLIANCE

DATE INITALS

10/11/89 MUE

10/11/89 MLE

N/A

$\mathrm{N} / \mathrm{A}$

10/11/89 N NE

$10 / 11 / 89$ ME

$10 / 11 / 89$ HLE

$10 / 11 / 89$ NLE

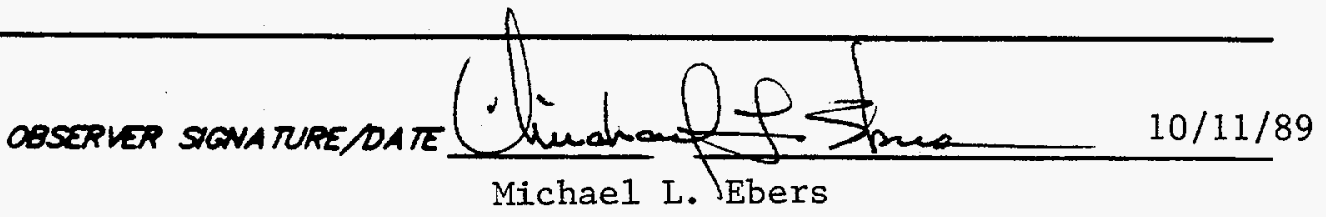




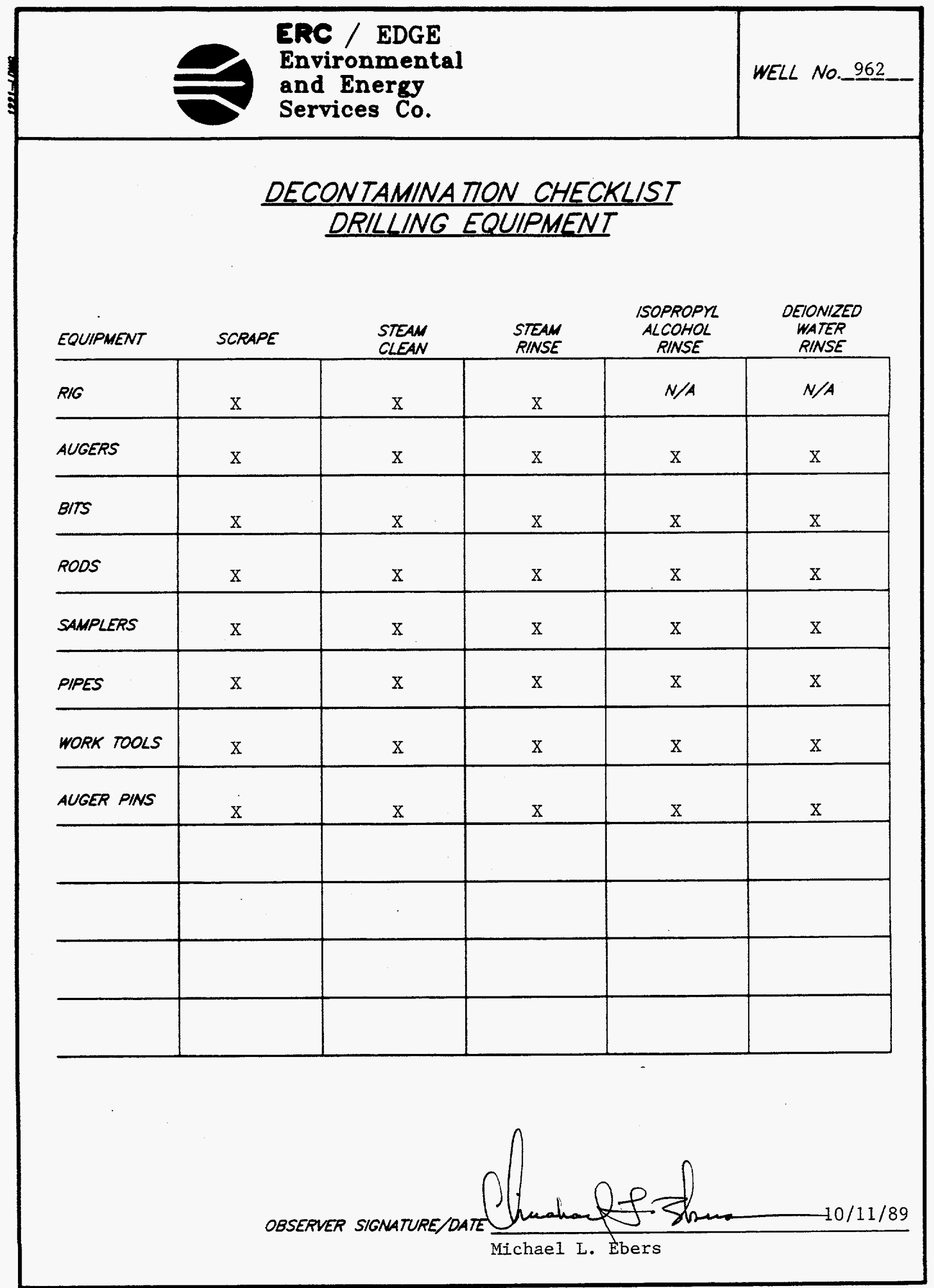




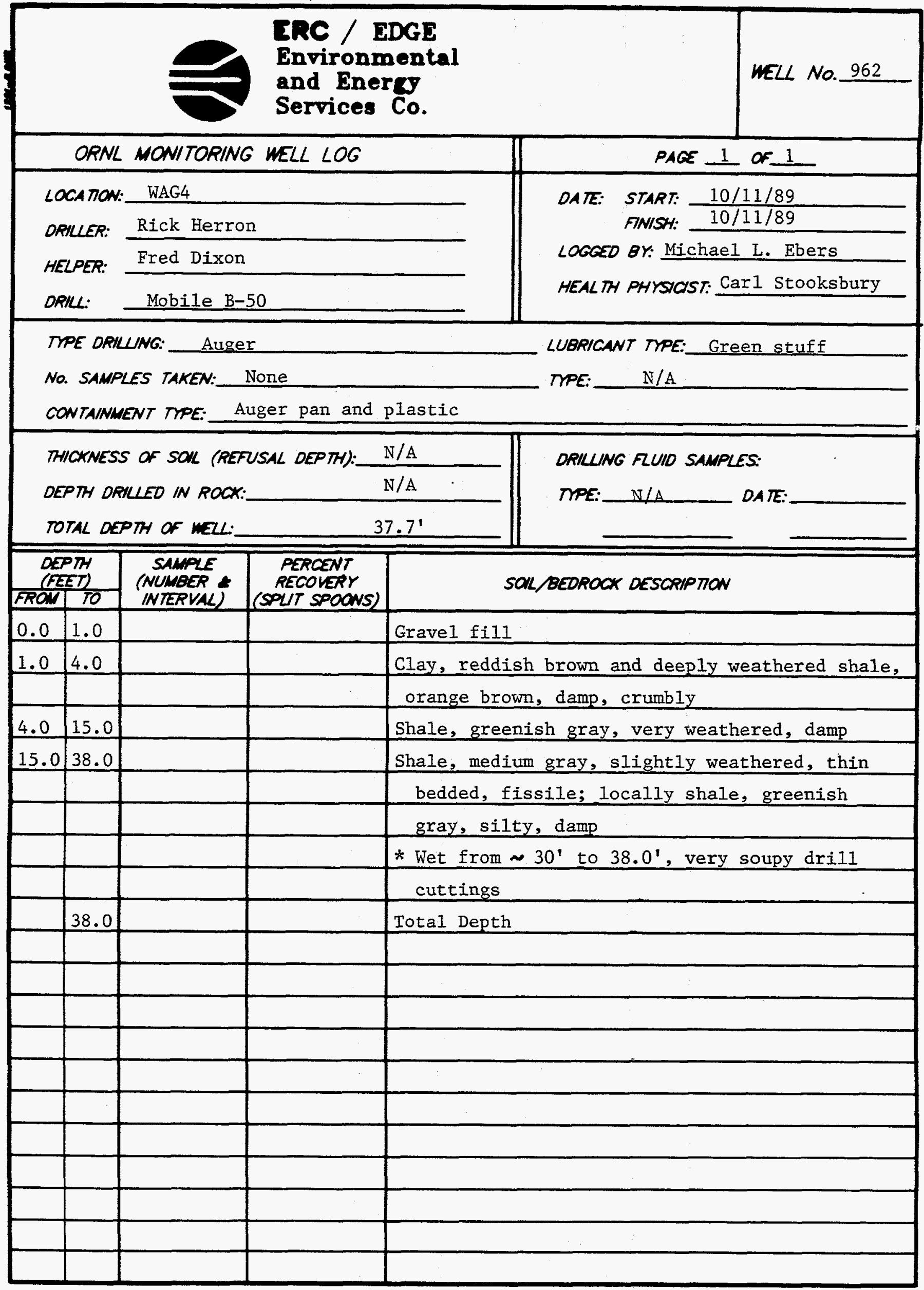




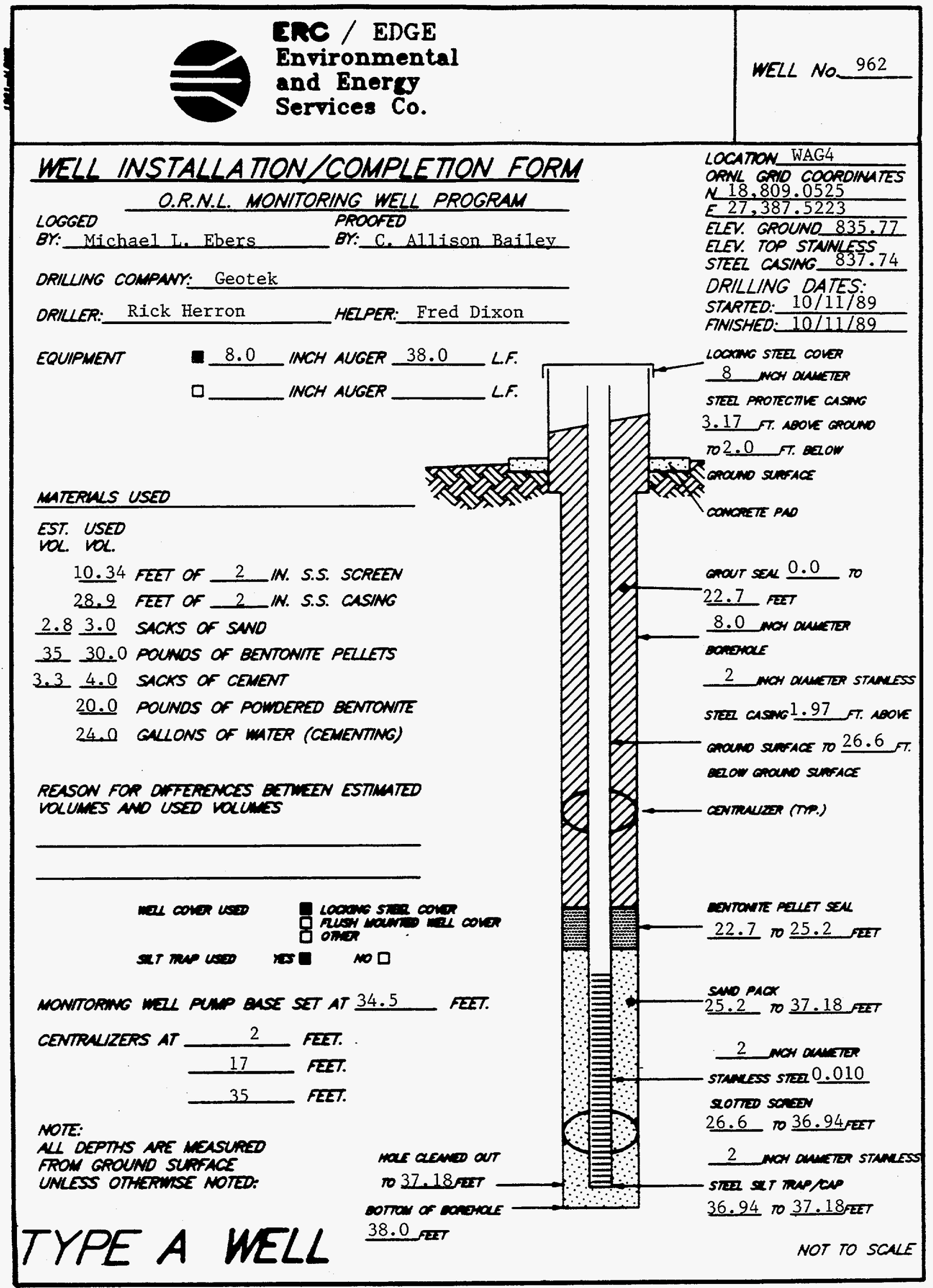


ERC / EDGE

Environmental

WELL NO. 962

and Energy

Services Co.

\section{MONITORING WELL MATERIALS \\ CERTIFICATION}

\begin{tabular}{|c|c|c|}
\hline ITEM/MA TERIAL & DAIE USED & BATCH NUMBER \\
\hline SANO & $10 / 11 / 89$ & 1 \\
\hline BENTONITE & $10 / 11 / 89$ & MMES Stores \\
\hline $\begin{array}{lll}\text { STAINLESS STEEL SCREEN } & \text { (PREPACKAGED } & \text { YES } \\
\end{array}$ & $10 / 11 / 89$ & MMES Stores \\
\hline $\begin{array}{lll}\text { STAINLESS STEEL CASING } & \text { (PREPACKAGED } & \text { YES } \\
\text { NO }\end{array}$ & $10 / 11 / 89$ & MMES Stores \\
\hline STAINLESS STEEL CENTRALIZERS (PREPACKAGED 1 YES $)$ & $10 / 11 / 89$ & MMES Stores \\
\hline $\begin{array}{ll}\text { STAINLESS STEEL CAPS } & \text { (PREPACKAGED } \\
\end{array}$ & $10 / 11 / 89$ & MMES Stores \\
\hline (PREPACKAGED $\quad$ DO & $6 / 14 / 90$ & 8 \\
\hline GROUT & $10 / 11 / 89$ & 2 \\
\hline WELL COVERS & & \\
\hline SURFACE CASING & $10 / 89$ & 1 \\
\hline
\end{tabular}

COMMENTS:

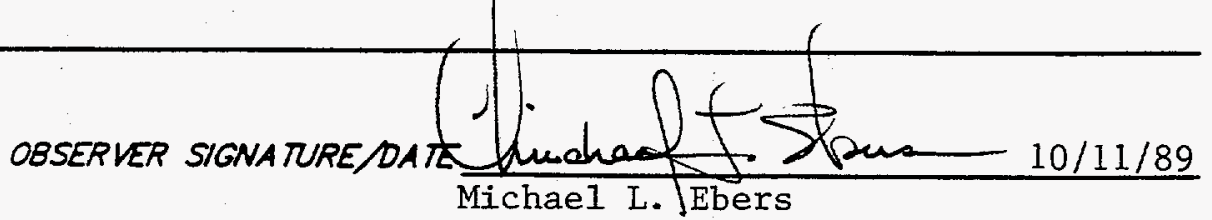




\section{POST-MELL COMPLETION CHECKLIST}

\section{POST-MELL COMPLETION TASKS}

COMPLIANCE DATE INITIALS

1. WU SCRAPED FROW AUGERS SMWPLERS ANO ALL OTHER EOUIPWENT.

2. ALL NUD FRON RIG ANO EQUIPWENT SCRAPINGS ANO CUTINUS OISPOSED OF IN ACCORDANCE IITH THE SPECIFCA ITON PROWOED.

3. WEZ DEVELOED IN ACCOPOANCE WTH THE SPECAFCA TON PROMOED AND DETAKS OF THE OEVELOPWENT ACTUTH RECOROED.

4. OAKLNG STE PROPERLY QLEANED UP AFTER COMPLEMON OF MEL INSTALLATON.

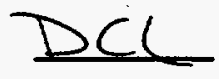

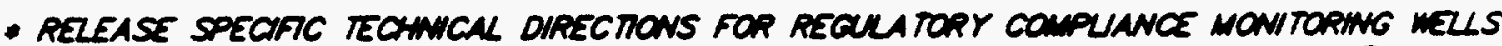
PHASE I. OAK RIDCE NAMONAL LABORATORY, OAK RMDEE M.0. K-4147, APRK 1987.

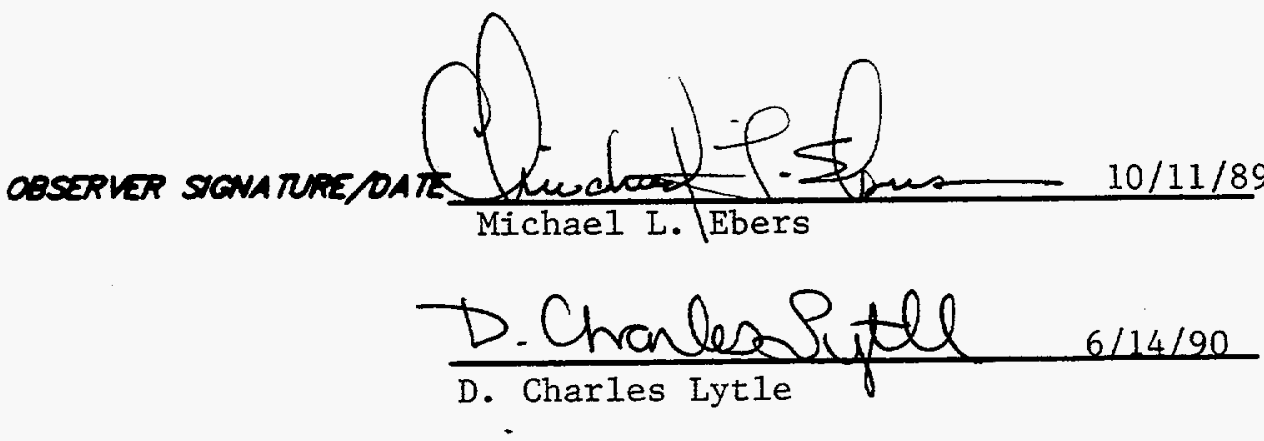




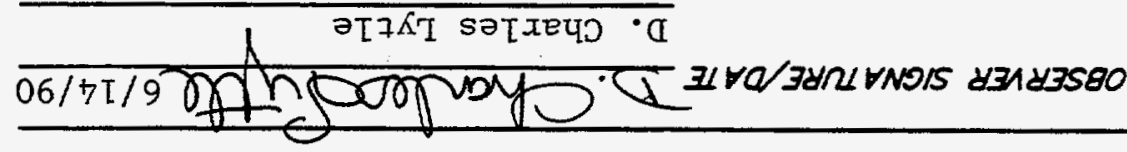

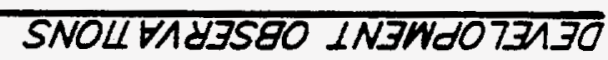

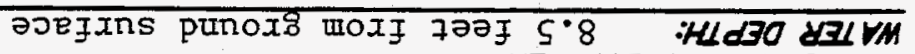
INBWDOZZ130-38d $7 \% U / N$

\begin{tabular}{|c|c|c|}
\hline 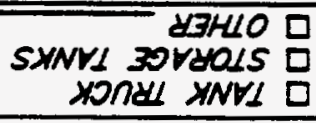 & 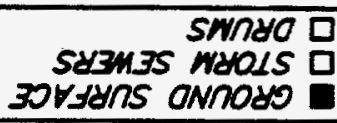 & $\begin{array}{r}.01 \\
\text { O3OUYHOSIO } \\
\text { XII VM }\end{array}$ \\
\hline & & 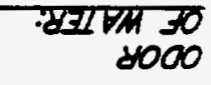 \\
\hline
\end{tabular}

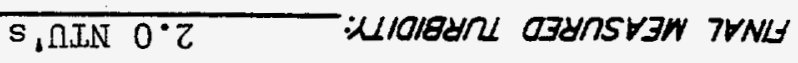

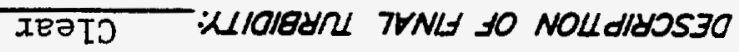

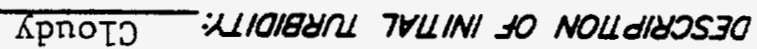

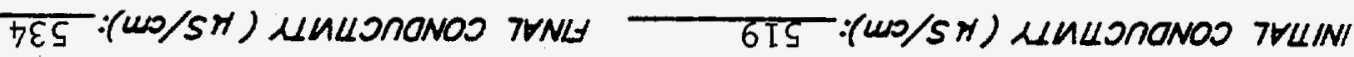
Z.8 :Hd 7VNL

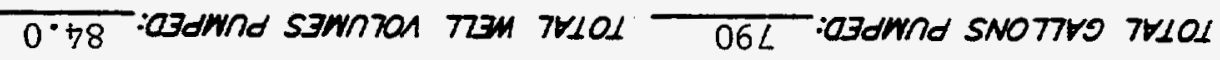
SNO7769

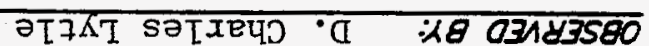
INBWDO 73130

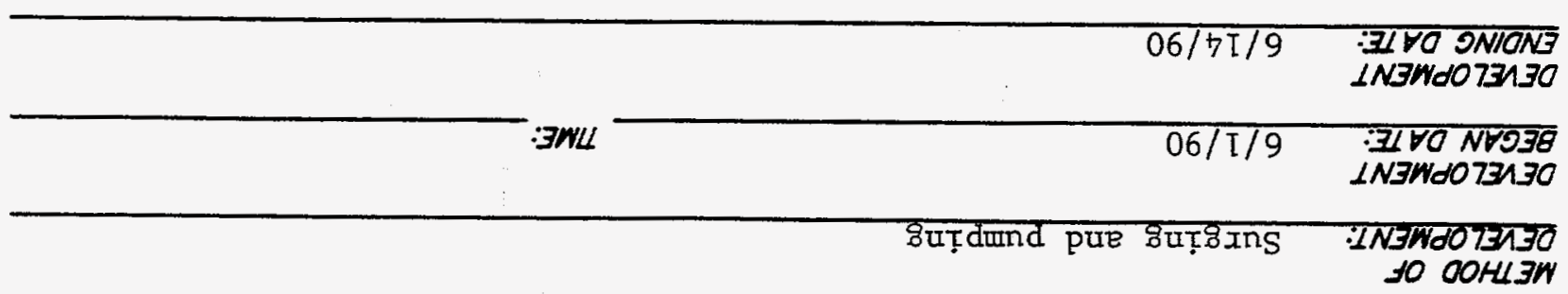
TTZM DNIYOLINON

TDFM $:$ NOU $\forall 007$ xadd $\square$

296 ON 773 M op saotaras c8soug pus [equamuoxtaug 
ERC / EDGE

Environmental

and Energy

Services Co.

MEI NO. 962

Upper

DATE: $6 / 1 / 90$

\section{MONITORING WELL DEVELOPMENT PROGRESS}

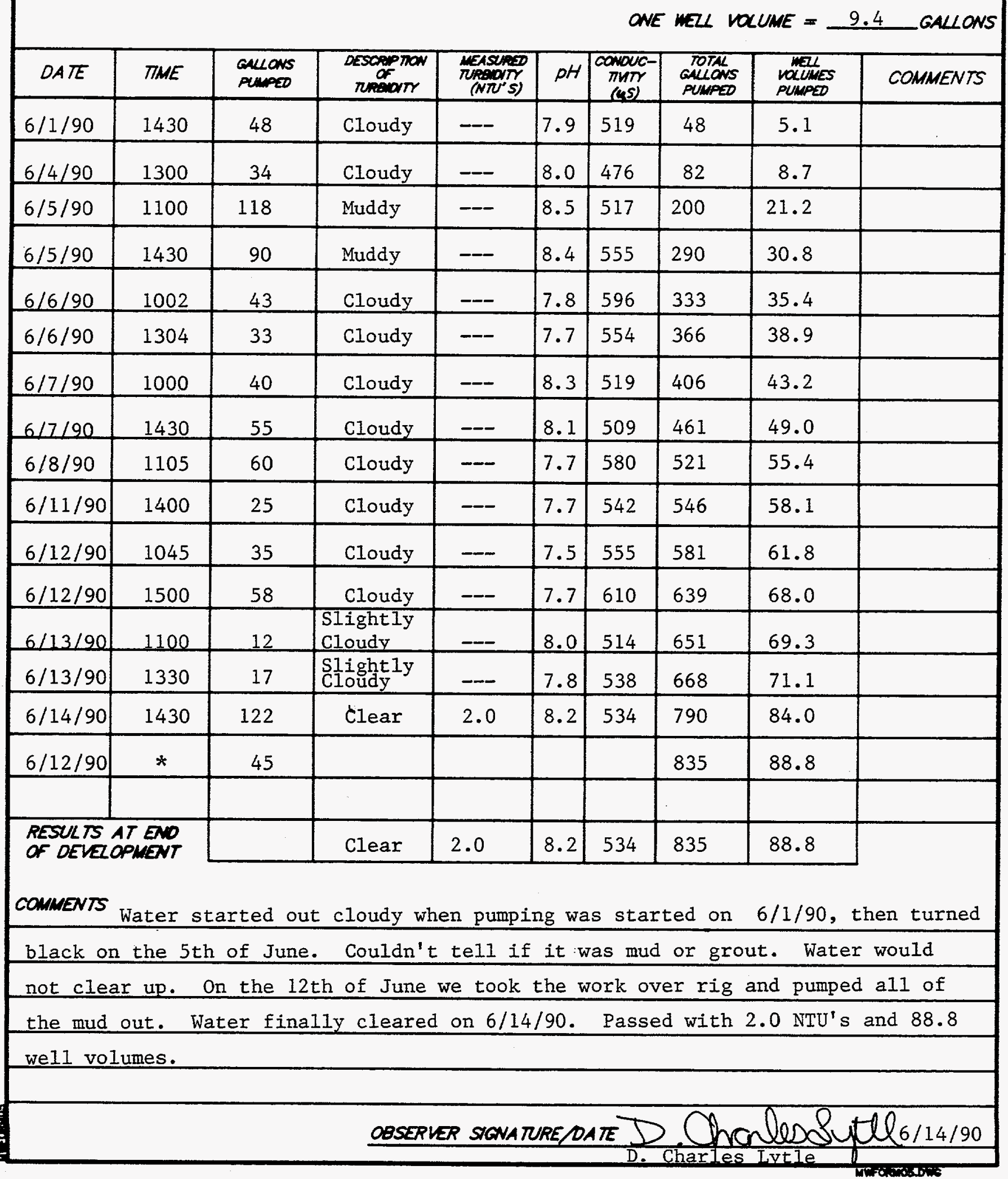

PAGE 13 of 17. 
ERC / EDGE

Environmental

WELL NO. 962

\section{HYDRAULIC CONDUCTIVTY CALCULATIONS}

PROGRAM SLUGT, VERSION 4.1, NOV. 1986

\section{THIS PROGRAM CALCULATES MEAN TRANSMISSIVITIES FROM}

SLUG-TEST DATA BASED ON TWO ANALYTICAL APPROACHES:

(1) METHOD OF COOPER, BREDEHOEFT AND PAPADOPULOS, 1967

(ARTICLE IN VOI.3, NO.I OF WRR ENTITLED

"RESPONSE OF A FINITE DIAMETER WELL TO AN INSTANTANEOUS CHARGE OF WATER")

(2) METHOD OF BOUWER AND RICE, 1976 (ARTICLE IN

VOL. 12, NO.3 OF WRR ENTITLED

"A SLUG TEST FOR DETERMINING HYDRAULIC CONDUCTIVITY OF UNCONFINED AQUIFERS WITH COMPLETELY OR PARTIALLY PENETRATING WELLS")

WEIL NO.: 962

DATE OF TEST: $10-30-90$

PROJECT NO.: E221-002

CLIENT: MMES

SITE LOCATION: WAG-4

EDGE, INC. FIELD INVESTIGATOR: JAMES W. CARUTHERS

INPUT DATA ARE:

INNER CASING DIAMETER $=2.00$ INCHES

INNER SCREEN OR OPEN-HOLE DIAMETER $=2.00$ INCHES

DIAMETER OF DRILLED HOIE $=8.00$ INCHES

LENGTH OF SCREEN OR INTAKE PORTION $=10.34$ FEET

DEPTH FROM STATIC LEVEL TO BOTTOM OF SCREEN $=26.60$ FEET

THICKNESS OF SATURATED AQUIFER ZONE $=10.34$ FEET

DEPTH TO STATIC WATER LEVEL BELOW REF. POINT $=1.00$ FEET

ESTIMATED POROSITY OF GRAVEL PACK $=.20$

FALLING-HEAD INDEX $=1$ ("I" IF FALLING, "O" IF RISING)

NUMBER OF DEPTH-TIME DATA POINTS = 32

HO WAS COMPUTED FROM INTERCEPT OF PLOT OF IOG(H) VS. TIME SUCCESSIVE COMPUTED

VALUES FOR HO

(FEET)

3.3657

3.3962 


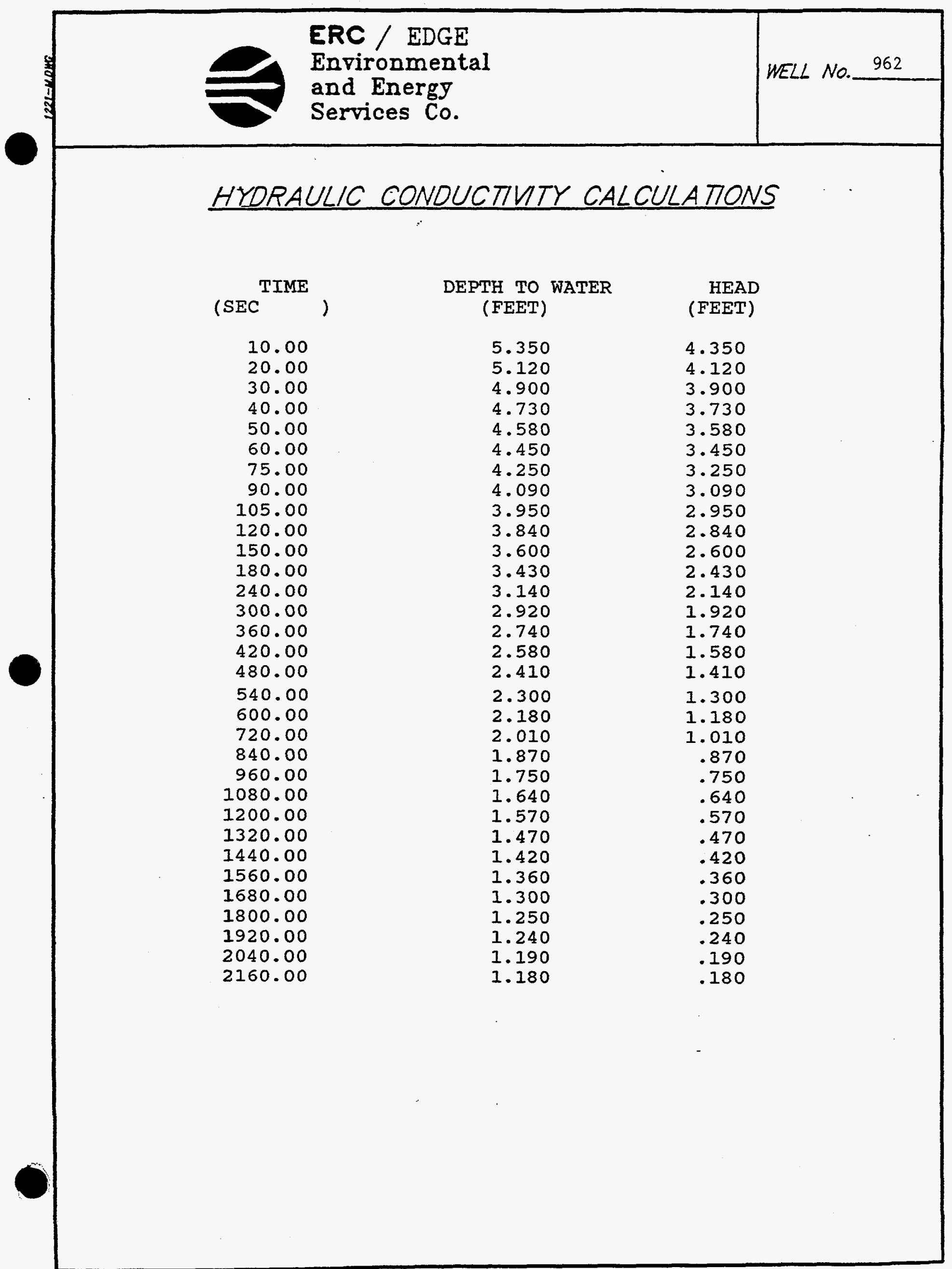




\section{HYDRAULIC CONDUCTIVTY CALCULATIONS}

$* * * * * * * * * * * * * * * * * * * * * * * * * * * * * * * * * * * * * * * * * * * * * * * * * * * * * * * * * * * * * *$ METHOD OF BOUWER AND RICE

COMPUTED RESULTS USING DIAMETER OF DRILLED HOLE:

$$
\begin{aligned}
& \text { PERMEABIIITY }=1.56 \mathrm{E}-06 \mathrm{FT} / \mathrm{SEC}=4.74 \mathrm{E}-05 \mathrm{CM} / \mathrm{SEC} \\
& \text { TRANSMISSIVITY }=1.61 \mathrm{E}-05 \mathrm{FT} * 2 / \mathrm{SEC}
\end{aligned}
$$

COMPUTED RESULTS USING DIAMETER OF CASING AND SCREEN:

$$
\begin{aligned}
& \text { PERMEABILITY }=2.15 \mathrm{E}-06 \mathrm{FT} / \mathrm{SEC}=6.55 \mathrm{E}-05 \mathrm{cM} / \mathrm{SEC} \\
& \text { TRANSMISSIVITY }=2.22 \mathrm{E}-05 \mathrm{FT} * 2 / \mathrm{SEC}
\end{aligned}
$$




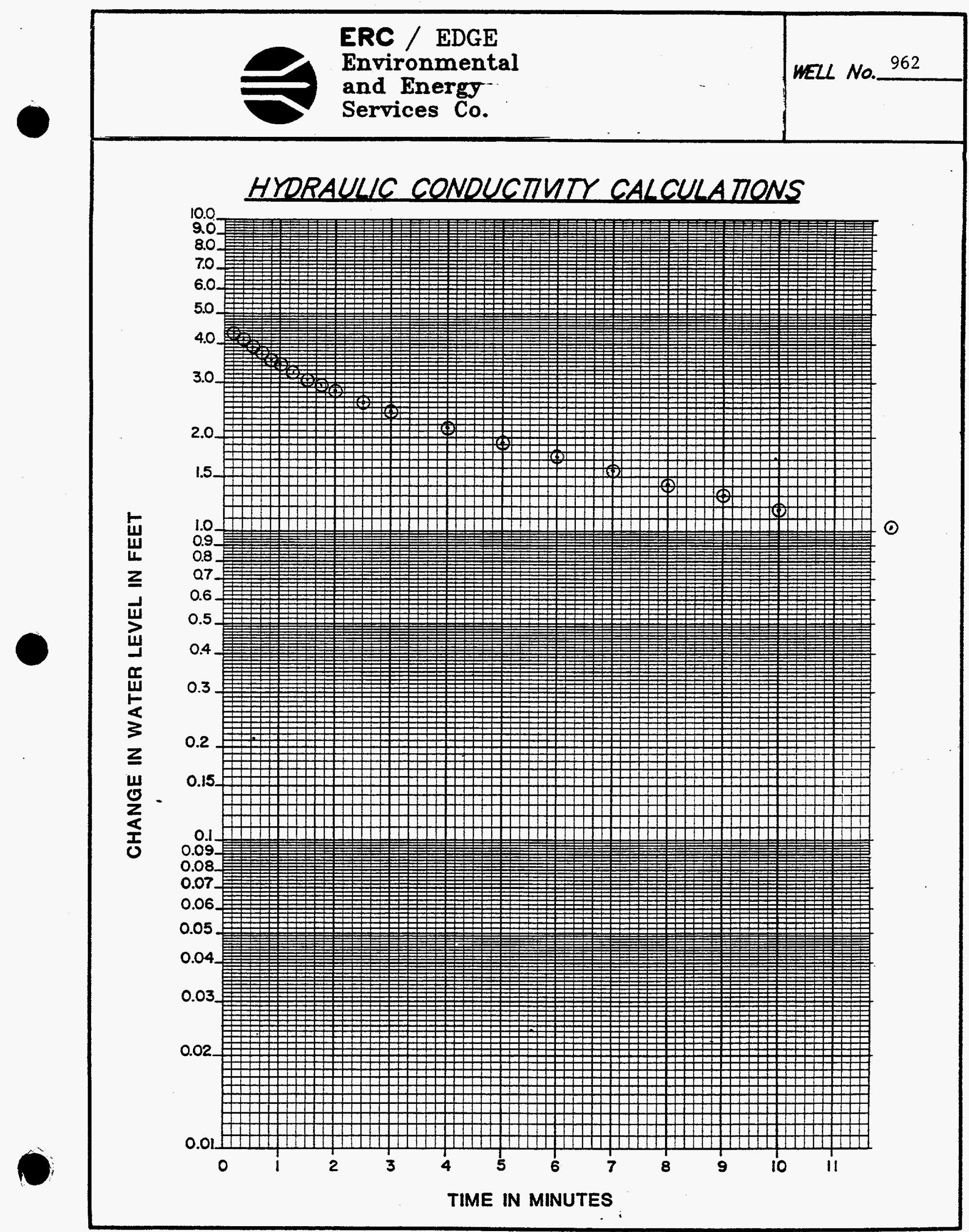




\section{Appendix B}

Operating Instructions for Handling Water and Cuttings from Well Drilling and Development of Groundwater Quality Monitoring Wells 
OPERATING INSTROCTIONS FOR HANDLING CUTTINGS AND WATER FROM FROY WELL DRILLING AND DEVELOPLENT OF THE

GROUNDWATER QUALITY MONITORING WELIS

Prepared by

J. A. Greene 


\section{PROCEDURE REVIEW AND APPROVAL Form}

Environmental and Health Protection Division

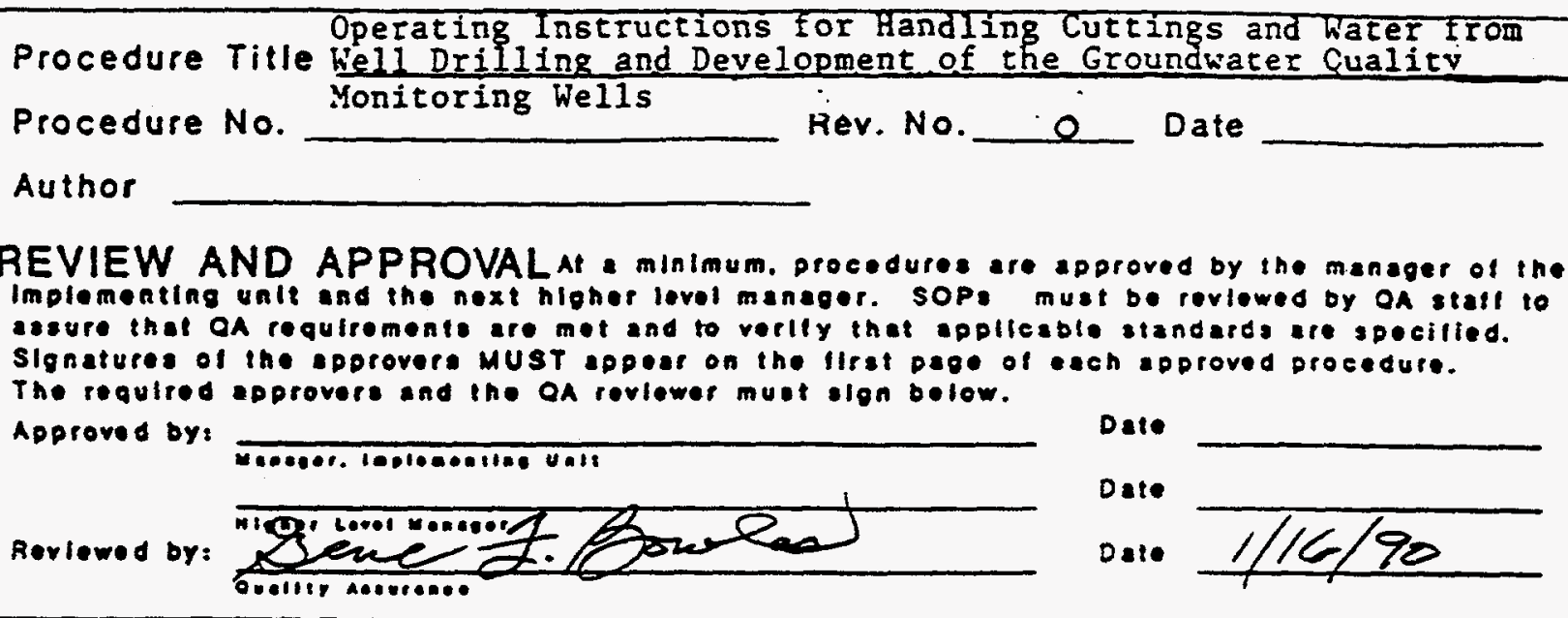

In the spaces betow Indleste addilonst reviews (R) or approvals (A). All reviewers and uppevere must ien and date this form betore the procedure can be linally approved. It more then one proesudre ls betho reviewed. attech llat.

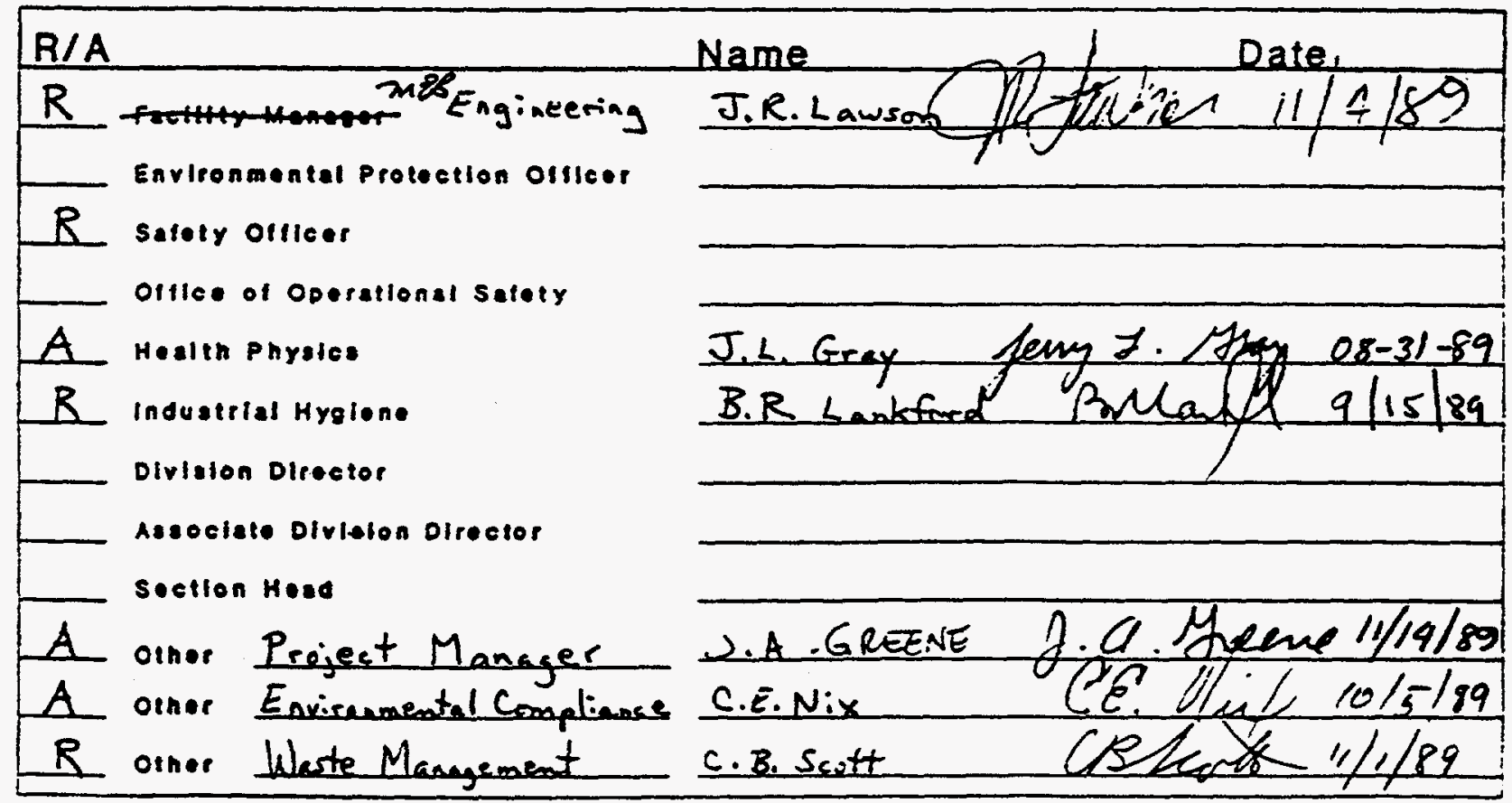

1. revision of the saRiosa requirear - Yes X NO

sionature

Next review detes: 2ures

Forward completed copy of this form to the division od office. 4500N. MS-6i66. 


\section{OPERATING INSTRUCTIONS FOR HANDLING CUTTINGS AND WATER FROM FROM WELL DRILLING AND DEVELOPMENT OF THE GROUNDWATER QUALITY MONITORING WELLS}

\subsection{PURPOSE}

The purpose of this document is to cite the steps that are followed to handle water and soil produced during the installation and development of wells.

2.0 SCOPE

This document applies to well drilling and development associated with the Groundwater Quality Monitoring Wells Installation Program at Oak Ridge National Laboratory.

\subsection{REFERENCE}

Health, Safety, and Environmental Protection Procedures for Excavating Operations, ORNL/M-116/R1, Oak Ridge National Laboratory, March 3, 1988.

\subsection{DEFINITIONS}

Well Ratings. Ratings assigned during the excavation permit cycle by Radiation Protection (RP) and Industrial Hygiene (IH) to indicate the probability of encountering radioactive and chemical contamination, respectively. These ratings are based on historical information or from previous drilling or excavation activity. The ratings are marked on the excavation permits. (RP ratings on permits may sometimes be called "HP" for "Health Physics." The two designations are interchangeable.) Protective measures required for the three categories are stated in Table 1, 'Excavation-classification categories," in ORNL/M-116/RI. The categories for soil handling are stated in Appendix $B$, 'Radiological Soil Handling Criteria,' in ORNL/M-116/RI.

RP Category 1. A rating assigned by RP which indicates that the probability of encountering radioactive contamination is low and that intermittent monitoring is required by $R P$.

II Category 1. A rating assigned by IH which indicates that the probability of encountering chemical contamination (i.e., organics) is low and that monitoring is not required by IH. An IH and/or Environmental Monitoring and Compliance (EMEC) representative will be called in any time chemical or hazardous contamination is suspected.

$R P$ Category 2. A rating assigned by $R P$ which indicates that the probability of encountering radioactive contamination is moderate and that continuous monitoring is required. The RP representative will determine the necessary level of protective clothing to be worn.

IH Category 2. A rating assigned by IH which indicates that the probability of encountering chemical contamination is moderate and that respirators must be on-site and ready for use by the workers when 
indicated by the IH or RP representative on-site. Location will be checked periodically with an IH field instrument, such as a Photovac or Organic Vapor Organizer (OVA).

RP Category 3. A rating assigned by $R P$ which indicates that there is a high probability of encountering radioactive contamination. Therefore, continuous monitoring by an RP representative is required, and protective clothing must be worn. In addition to the training listed above, workers must have successfully completed the Caregory 3 Driller Training course that is administered by Environmental and Health Protection Division (E\&HP) personnel.

IH Category 3. A rating assigned by IH which requires the workers to wear respirators as a minimum. Additional protection deemed appropriate by IH will be designated for each location. Continuous monitoring by IH personnel is required.

Trainfing Requirements. Training requirements for workers include the Basic Radiation Training administered by E\&HP personnel and the $40 \mathrm{~h}$ of training required by the Superfund Amendment Reauthorization Act (SARA) through a company-approved course. There is an additional training course required for Category 3 drilling.

Alx rotary containment box. A box specially designed to contain the cuttings and water that are blown from the borehole during air rotary drilling. The box is equipped with a high-efficiency particulate air (HEPA) filter to prevent particles that possibly contain contaminants from being dispersed into the air. Air rotary drilling is generally used only for drilling into bedrock.

Auger pan. A metal catch pan with a hole cut in the middle. The pan surrounds the borehole and contains soil cuttings as they are augered up.

Proper On-Site Disposal. Disposal of noncontaminated soil and water produced from work on a well at a location near the well that is not openly visible to the public and has no risk of causing erosion or direct discharge into a stream. The construction engineer (CE) will indicate to the drillers which areas are acceptable for on-site disposal. The pH will have been checked and adjusted to the 5-to-9 range before releasing. This precise definition is intended wherever this term is used in this procedure.

Proper Contaminated Waste Disposal. Generally, radioactively contaminated soil will be packaged in drums and tagged by the RP representative for disposal by ORNL Waste Operations. However, Category-2-level soil may be used on site as backfill in remote areas when covered by $1 \mathrm{ft}$ of noncontaminated soil as stipulated in ORNL/M. $116 / R I$. The $C E$ will specify to the drillers when a well location has been approved by EM\&C for on-site disposal of contaminated soll. This definition is intended wherever this term is used in this procedure. 
Temporary Drflling Equipment Cleaning Facility. An outdoor area located in Melton valley for steam cleaning of drill rigs and associated equipment, referred to as the steam cleaning area.

Containment Box Holding Pit. A lined pit at the Temporary Drilling Equipment Cleaning Facility. The contents of the pit will be sampled and tested for gross alpha, gross beta, pH, and tritium*, before being released through a silt fence. Contents that have a potential for containing hazardous materials (i.e., IH Category 2 and 3 locations) will have been checked with an IH field instrument before being released into the pit.)

Steam Cleaning Pits. Two lined pits at the Temporary Drilling Equipment Cleaning Facility that collect runoff from the steam cleaning operations. The contents of the pits will be sampled and tested for gross alpha, gross beta, $\mathrm{pH}$, and tritium*, before being released through a silt fence. Contents that have a potential for containing hazardous materials (i.e., IH Category 2 and 3 locations) will have been checked with an IH field instrument before being released into the pit.)

\subsection{RESPONSIBILITIES}

5.1 Radiation Protection Personnel monitor and determine the presence of detectable radioactive contamination in drill cuttings during well-drilling activities. They provide guidance to ensure that exposures to the workers, public, and environment are kept as low as reasonably achievable. They also provide radiation monitoring during the precursory cleaning by the drillers.

5.2 Well-Drilling Personnel perform well drilling and completion activities. They package soil and water in appropriate containers and transport it, if necessary; perform precursory cleaning of low-level contaminated equipment; and perform cleaning of equipment between the drilling of each well.

5.3 EDGe Hydrogeologists observe all crucial well installation activities and record data for all boreholes drilled. They do a visual inspection of the cuttings produced during augering and note any unusual occurrences and obvious deleterious material encountered during the drilling process. They check the cuttings and water with a Photovac or OVA or similar instrument and check $\mathrm{pH}$ of water when necessary.

5.4 Construction Engineer serves as the field contact and provides guidance to the drillers during field activities.

\subsection{PROCEDURE}

\subsection{EXPLANATION OF THE WELL RATING SYSTEM}

Each well is assigned a rating by $R P$ and $I H$ before drilling begins. Because additional information is gained during drilling, 
well ratings may be changed by $R P$ and $I H$ as the work progresses. A lower RP Category rating will be changed to a Category 3 rating upon encountering radioactive contamination within the Category 3 range defined in ORNL/M-116/R1. Likewise, an IH Category 3 may result if chemical contamination is detected in a well with a lower rating. The RP and/or IH representative on site will notify the on-site personnel when conditions warrant a rating change. Any additional actions or modifications in protective clothing required by the rating change will be executed at that time. The change will be documented immediately by the on-site hydrogeologist in the well data package and as soon as possible by the RP and/or IH representative by a signed written statement stating the well number, the old and new ratings, and the rationale supporting the change. The statement will be sent by the RP and/or IH representative to the Construction Engineer (CE) for filing with the original excavation permit. A copy will be sent to the RAP Well Installation Manager by the CE.

A well category also may be changed from a higher rating to a lower rating. For example, if no contamination is encountered while drilling a Category 2 or 3 well, it may be changed to a lower rating after drilling to a certain depth or for development purposes, depending on the history of the area. The documentation procedure stated above for an increase in rating must also be followed for a decrease in rating.

\subsection{CATEGORY 1 WELIS (RP OR IH)}

\subsubsection{Category 1 Drilling}

\subsubsection{Category 1 Auger Cuttings}

a. Auger cuttings will be collected in a catch pan.

b. An RP representative will scan the cuttings intermittently to check for radioactive contamination. Cuttings will be inspected for any unusual discoloration or odor by the hydrogeologist.

c. If there is no contamination detected, proper on-site disposal or disposal at the steam cleaning area will be done.

\subsubsection{Category 1 Air Rotary Drilling}

a. Cuttings will be collected in a containment box.

b. When the containment box is full, one of the following will be done to empty cuttings and/or decant water from the containment box:

(1) proper on-site disposal. 
(2) disposal at the containment box holding pit.

6.2.2 Category 1 Well Development

6.2.2.1 Water removed from the well will be contained in drums.

6.2.2.2 The pH of the water will be measured and will be adjusted to be between 5 and 9 by the $C E$ if it is above or below that range.

6.2.2.3 Drums of water will be discarded by proper on-site disposal or disposal at the steam cleaning area will be done.

\subsection{CATEGORY 2 WELLS (RP AND IH)}

\subsubsection{Category 2 Drilling}

\subsubsection{Category 2 Auger Cuttings}

a. Auger cuttings will be collected in a catch pan.

b. An RP representative will scan the cuttings continuously to check for radioactive contamination. Cuttings will be inspected for any unusual discoloration or odor and tested with a Photovac or OVA by the hydrogeologist for presence of RCRA materials.

c. If there is no contamination detected, proper on-site disposal or disposal at the steam cleaning area will be done.

d. Cuttings will be contained in drums if contamination is detected. Proper disposal will be arranged by Martin Marietta Energy Systems through Waste Operations.

\subsubsection{Category 2 Air Rotary Drilling}

a. Rock cuttings and drill water will be collected in a containment box.

b. When the containment box becomes full, the RP representative will perform a wet towel smear to detect the presence of radioactive contamination. An inspection for unusual discoloration or odor and tests with an OVA will be conducted for the presence of RCRA materials by the heologist. 
c. If no contamination is detected, one of the following will be done to empty cuttings and/or decant water from the containment box:

(1) proper on-site disposal.

(2) disposal at the containment box holding pit.

d. If contamination is detected by the tests, arrangements will be made by Martin Marietta Energy Systems through Waste Operations to properly dispose of the water. Further laboratory testing of the box contents may be done.

\subsubsection{Category 2 Development}

6.3.2.1 Water removed from the well will be contained in drums.

6.3.2.2 When the drums are ready to be emptied, the RP representative will perform a wet towel smear to detect the presence of radioactive contamination. An inspection for unusual discoloration or odor and tests with an OVA will be conducted for presence of RCRA materials by the hydrogeologist. The pH will be adjusted if necessary.

6.3.2.3 If no contamination is detected, the water will be discarded by proper on-site disposal or disposal at the steam cleaning area will be done.

6.3.2.4 If contamination is detected by the tests, arrangements will be made by Martin Marietta Energy Systems to properly dispose of the water. Further laboratory testing may be done.

\subsection{CATEGORY 3 WELIS (RP AND IH)}

\subsubsection{Category 3 Drilling}

\subsubsection{Category 3 Augering}

a. When a well is classified as an RP Category 3 or an IH Category 3 , continuous monitoring will be required by RP and IH. Wearing of respirators will be required. Cuttings will be inspected for any unusual discoloration or odor. Tests for chemical contanination (i.e., organics) will be performed with IH field instruments by an IH representative for IH Category 3 wells. Tpecially trained personnel will be required to do the drilling. 
b. If no contamination is detected by $R P$ or IH while augering through soil to bedrock, a rating may be changed by RP or IH to a Category 2 depending on the depth, the type of contamination expected, and the history of the area.

c. If contamination is detected during augering, cuttings will be drummed. Proper disposal of all cuttings and water will be arranged by Martin Marietta Energy Systems.

\subsubsection{Category 3 Air Rotary Drilling}

a. Rock cuttings and drill water will be collected in a containment box.

b. When the containment box becomes filled with water and/or cuttings, a sample will be collected by EM\&C and will be tested by the Analytical Chemistry Division for gross alpha, gross beta, tritium*, for an RP Category 3. If it is an IH Category 3, the IH representative on-site will determine which (if any) laboratory testing is necessary for chemical contaminants.

c. Proper disposition of the containment box contents will be decided by consensus of E\&HP, the IH or RP representative, EM\&C, and the CE, based on the results from Analytical Chemistry Division of the above tests.

\subsubsection{Category 3 Development}

6.4.2.1 Water pumped from Category 3 wells will be contained in drums. Samples will be collected by EM\&C and will be tested by Analytical Chemistry Division for gross alpha, gross beta, tritium*, and pH. It will be tested with IH field instruments by IH representatives for the presence of RCRA materials.
6.4 .2 .2
A decision based on the test results will be made between E\&HP and Engineering whether to continue development.

\subsection{BOREHOLE CLEANING}

When sludge and water have accumulated in the bottoms of boreholes drilled in soil, the boreholes must be cleaned out prior to setting casings. A decision based on the location of the borehole and its rating will be made between the RP and/or IH representatives whether the sludge and water from the borehole must be contained in a drum. Water and sludge from a Category 2 well will be drummed, and a wet towel smear will be done by RP to 
determine proper disposal of the drum contents. Laboratory testing of the drum contents for gross alpha, gross beta, tritium*, and pH will be cone if recommended by the RP or IH representative. Water and sludge removed from an RP Category 3 well will be drumed, and laboratory testing will be done for gross alpha, gross beta, tritium*, and pH. EM\&C will be consulted to determine proper disposal based on the test results. Further laboratory testing to determine actual contaminants will be done if recommended by EM\&C.

"Testing for tritiun will be done for wells located in areas where tritium contamination is suspected. This decision will be made between RP and Exte. 
8

D

C

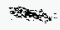


6

5

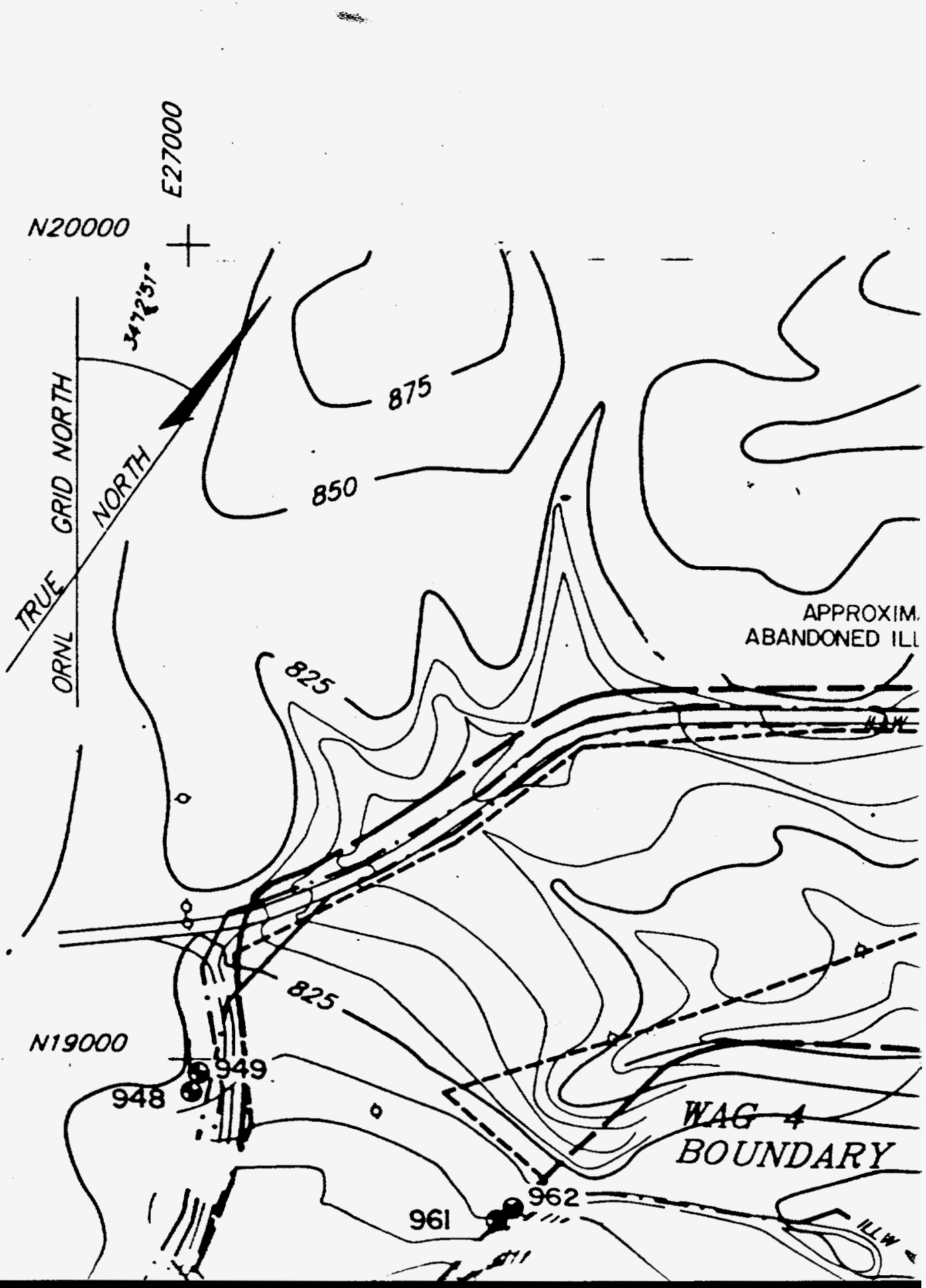


0
8
4

8

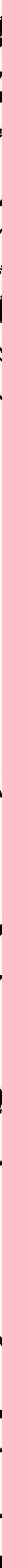




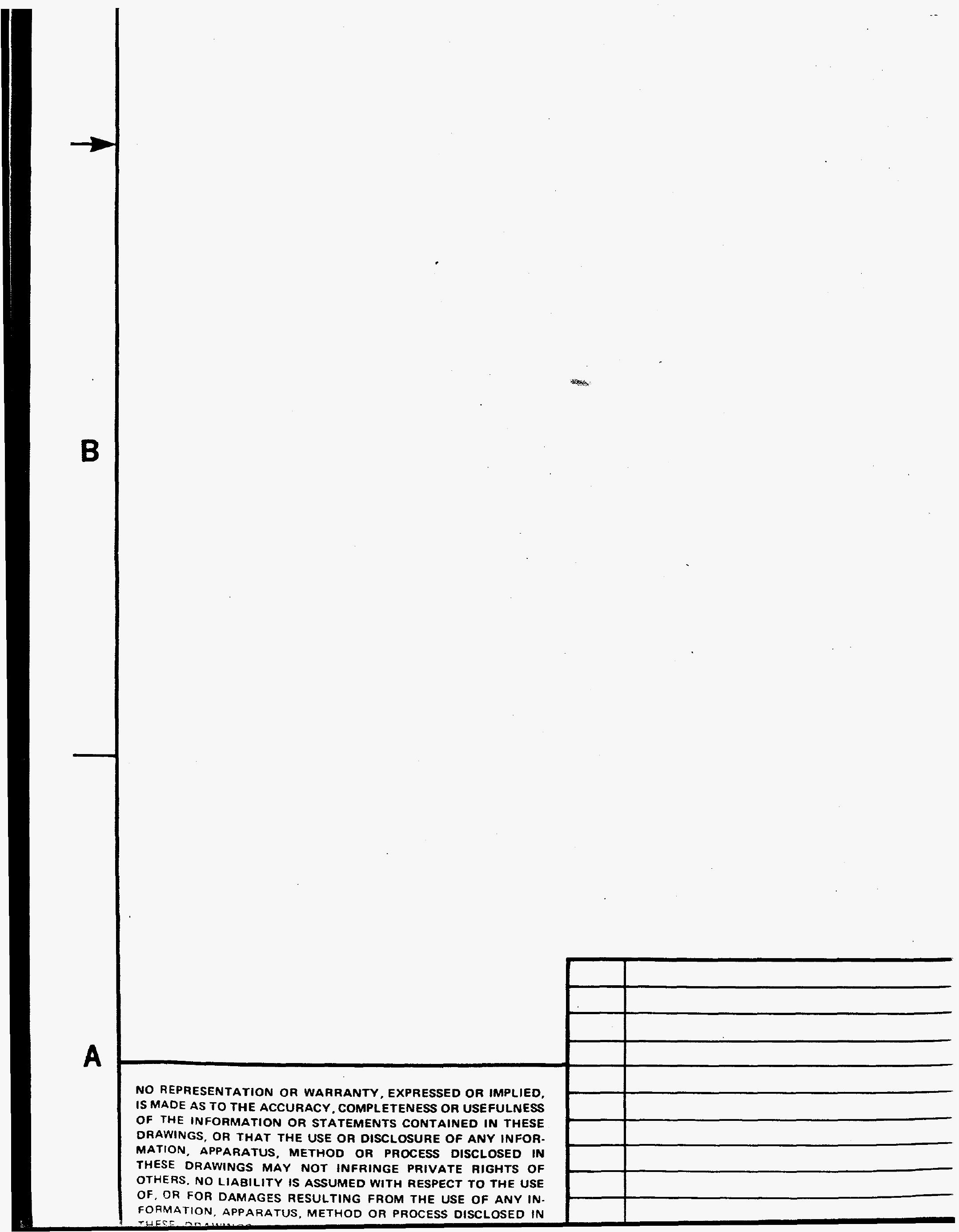




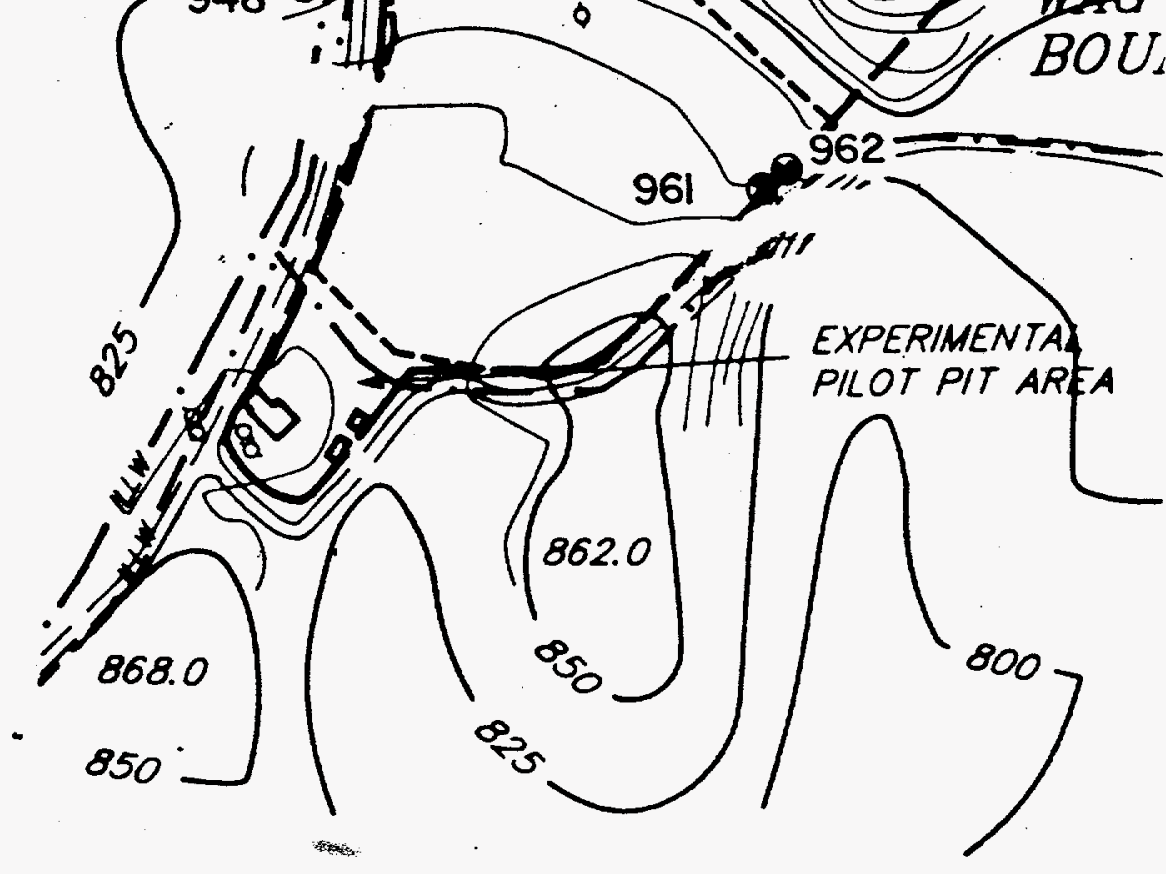
$\frac{\text { WAG } 4 \text { GROUND }}{\text { WELLS AS }}$

WELL \#

951

952

953

954

955

956

957

958

959

960

961

962

\begin{tabular}{|l|l|l|l|l|l|l|l|l|l|l|l|l|}
\hline & & & & & & & & & \\
\hline & & & & & & & & & \\
\hline & & & & & & & & & & \\
\hline
\end{tabular}




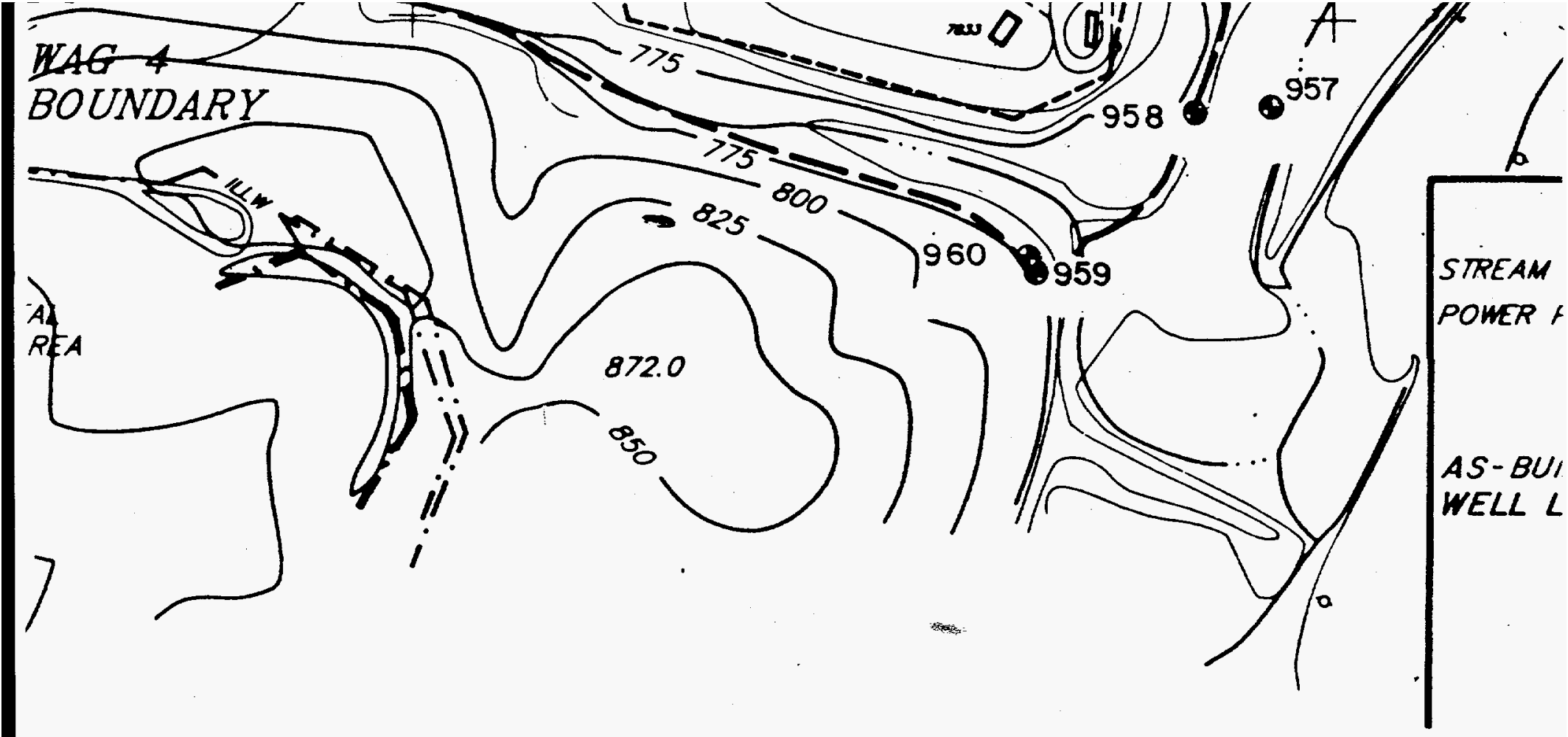

BOUNDWATER QUALITY MONITORING

ELLS AS-BUILT COORDINATES

\begin{tabular}{ll} 
NORTHING & EASTING \\
\hline $18,959.25$ & $27,001.43$ \\
$18,977.16$ & $27,004.24$ \\
$19,594.61$ & $28,013.51$ \\
$19,594.29$ & $28,028.70$ \\
$19,597.79$ & $28,670.76$ \\
$19,594.13$ & $28,686.09$ \\
$19,252.06$ & $29,252.93$ \\
$19,243.54$ & $29,239.15$ \\
$19,123.72$ & $28,935.51$ \\
$18,908.93$ & $28,861.00$ \\
$18,900.37$ & $28,857.05$ \\
$18,729.07$ & $28,682.44$ \\
$18,742.04$ & $28,674.37$ \\
$18,799.18$ & $27,371.38$ \\
$18,809.05$ & $27,387.52$
\end{tabular}

\begin{tabular}{|l|l|l|l|l|l|l|l|l|l|l|}
\hline & & & & & & & & & & UNL \\
\hline & & & & & & & & & & \\
\hline & & & & & & & & \\
\hline \\
\hline
\end{tabular}




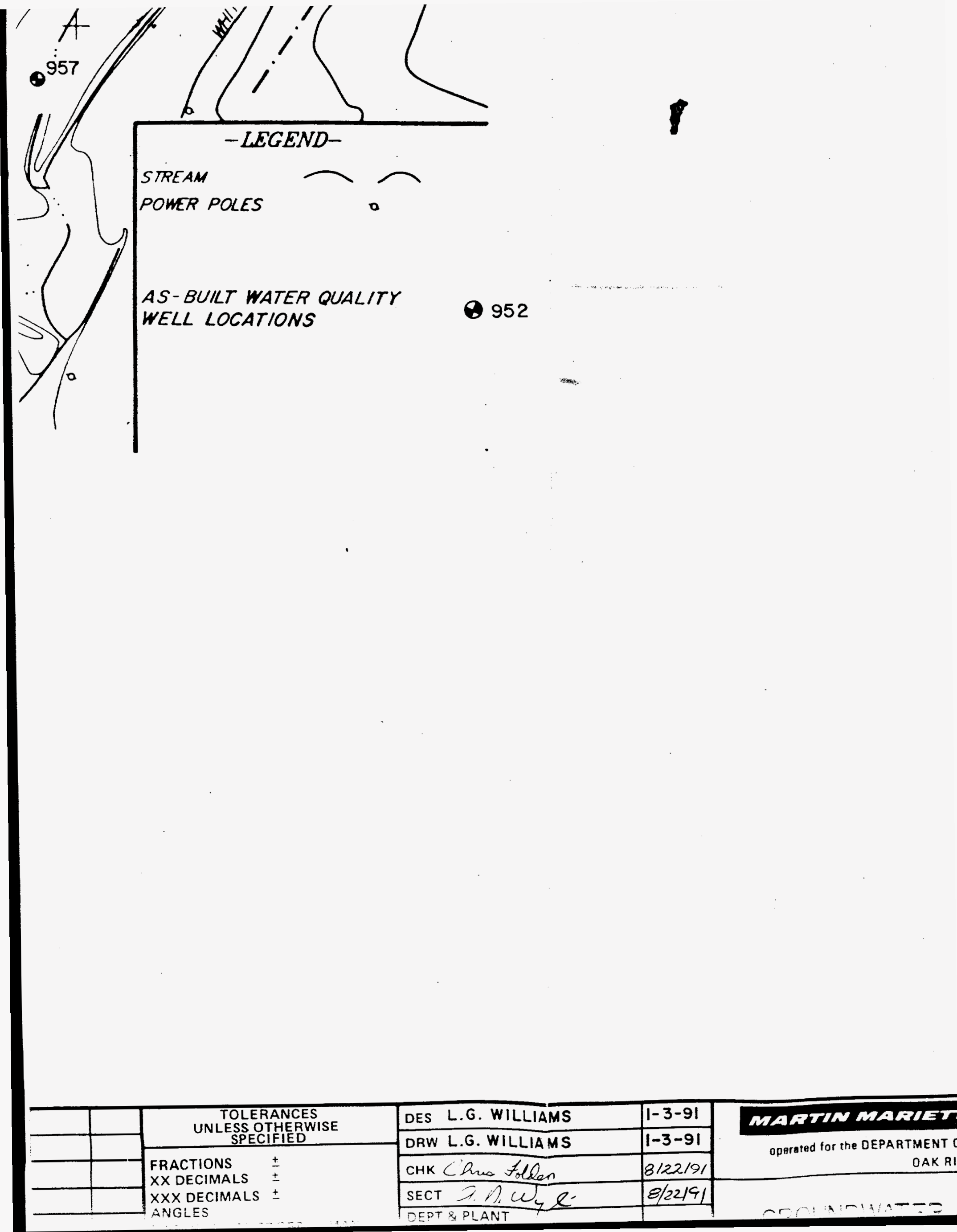


NO REPRESENTATION OR WARRANTY, EXPRESSED OR IMPLIED, IS MADE AS TO THE ACCURACY, COMPLETENESS OR USEFULNESS OF THE INFORMATION OR STATEMENTS CONTAINED IN THESE DRAWINGS, OR THAT THE USE OR DISCLOSURE OF ANY INFORMATION, APPARATUS, METHOD OR PROCESS DISCLOSED IN THESE DRAWINGS MAY NOT INFRINGE PRIVATE RIGHTS OF OTHERS. NO LIABILITY IS ASSUMED WITH RESPECT TO THE USE OF, OR FOR DAMAGES RESULTING FROM THE USE OF ANY IN. FORMATION, APPARATUS, METHOD OR PROCESS DISCLOSED IN THESE DRAWINGS. DRAWINGS MADE AVAILABLE FOR INFOR. MATION TO BIDDER ARE NOT TO BE USED FOR OTHER PURPOSES. AND ARE TO BE RETURNED UPON REQUEST OF THE FORWARDING CONTRACTOR.

\begin{tabular}{|c|c|}
\hline & \\
\hline & \\
\hline & \\
\hline & \\
\hline & \\
\hline & \\
\hline & \\
\hline & \\
\hline & \\
\hline & \\
\hline 0 & ISSUED APPROVED \\
\hline REV & \\
\hline & \\
\hline & 7
\end{tabular}


WAG 4 GROUNE

WELLSA

WELL \#

948

949

950

951

952

953

954

955

956

957

958

959

960

961

962

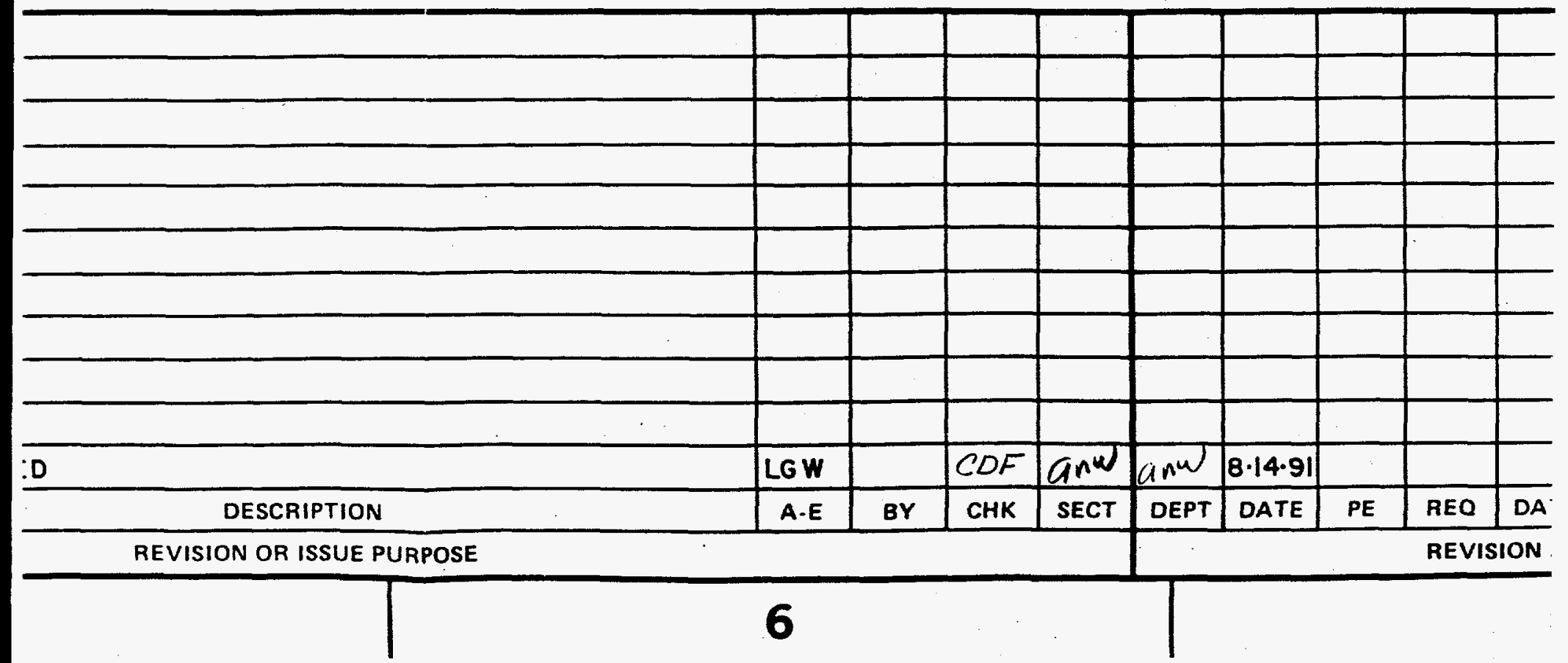



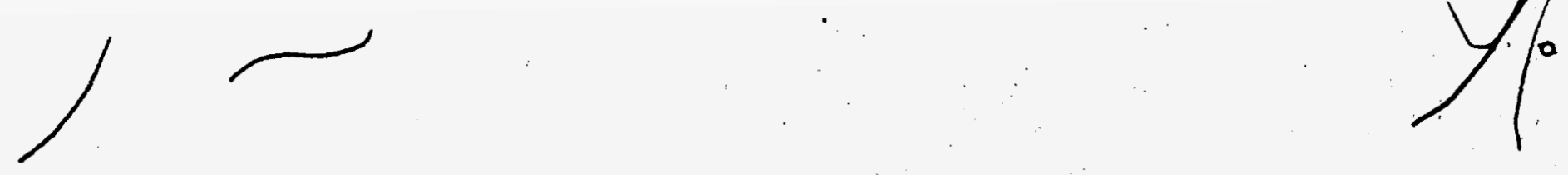

WAQ 4 GROUNDWATER QUALITY MONITORING WELLS AS-BUILT COORDINATES

\begin{tabular}{lll} 
IELL \# & NORTHING & EASTING \\
\hline 48 & $18,959.25$ & $27,001.43$ \\
49 & $18,977.16$ & $27,004.24$ \\
30 & $19,594.61$ & $28,013.51$ \\
$j 1$ & $19,594.29$ & $28,028.70$ \\
$j 2$ & $19,597.79$ & $28,670.76$ \\
$i 3$ & $19,594.13$ & $28,686.09$ \\
$j 4$ & $19,252.06$ & $29,252.93$ \\
$j 5$ & $19,243.54$ & $29,239.15$ \\
$j 6$ & $19,123.72$ & $28,935.51$ \\
$j 7$ & $18,908.93$ & $28,861.00$ \\
$j 8$ & $18,900.37$ & $28,857.05$ \\
9 & $18,729.07$ & $28,682.44$ \\
0 & $18,742.04$ & $28,674.37$ \\
1 & $18,799.18$ & $27,371.38$ \\
2 & $18,809.05$ & $27,387.52$
\end{tabular}

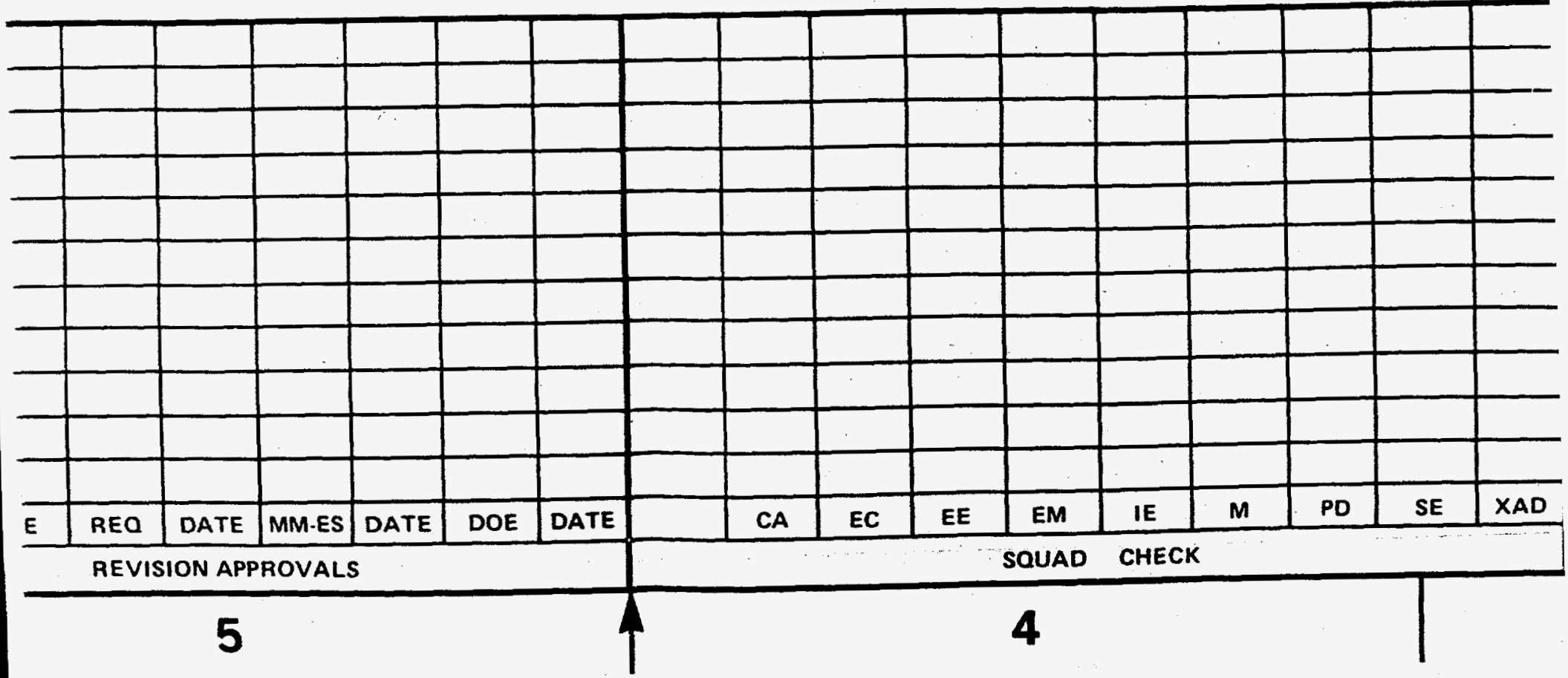




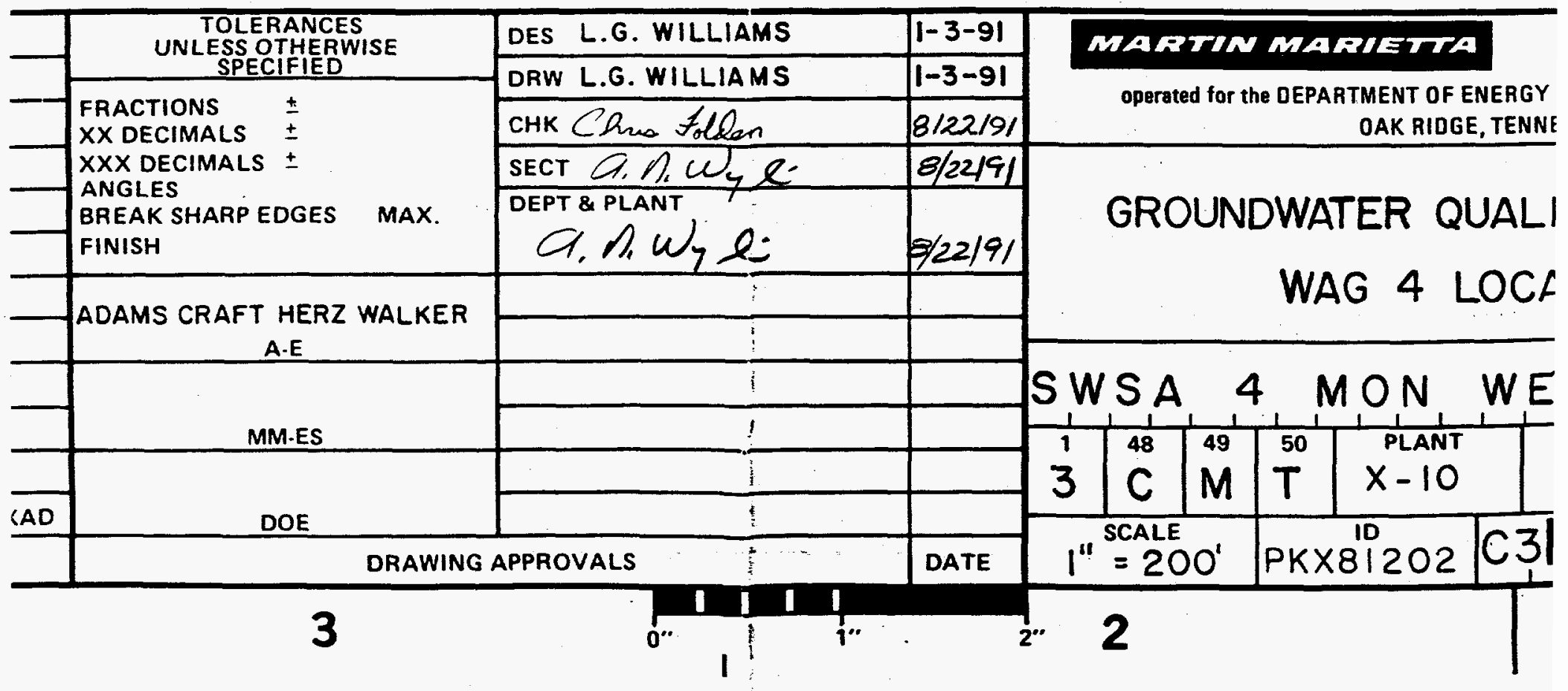




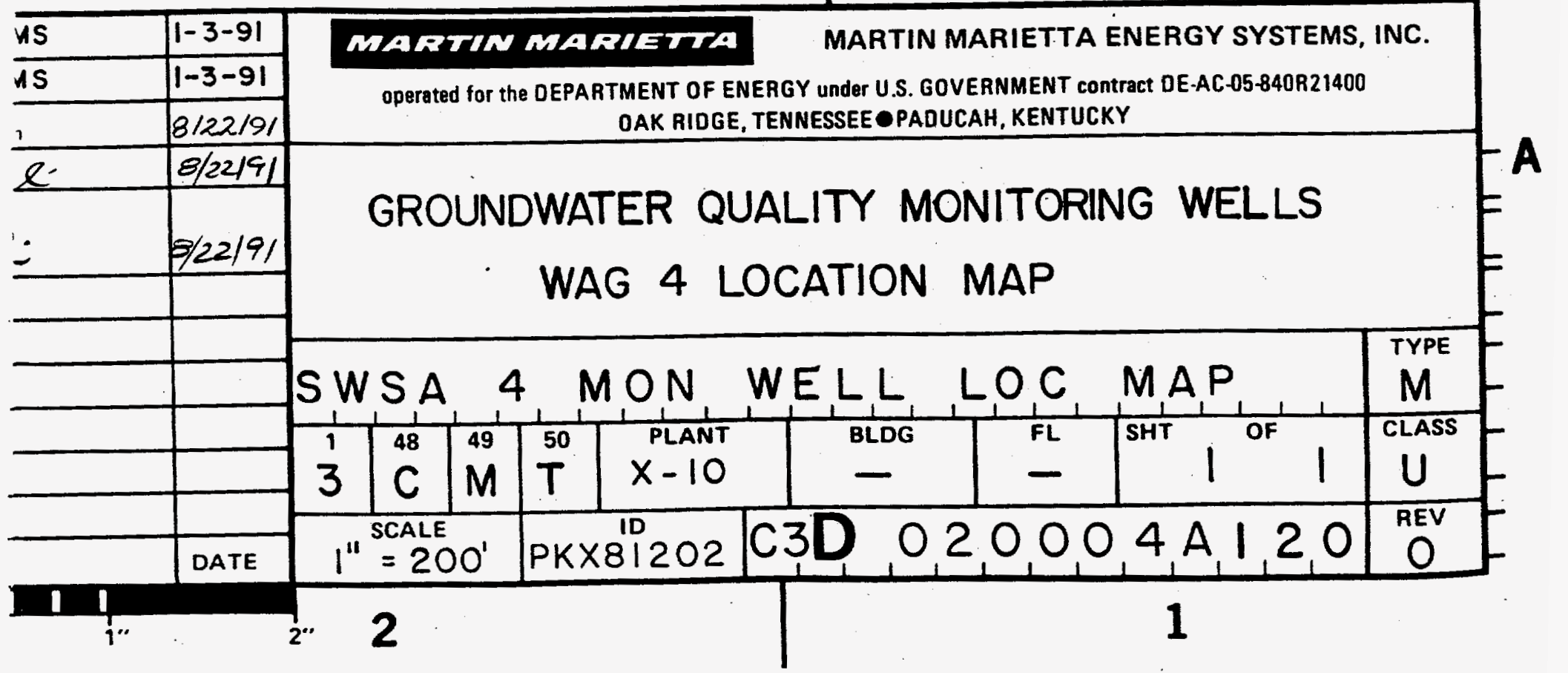




\section{DISTRIBUTION}

1. F. P. Baxter

2. C. A. Bednarz

3. H. L. Boston

4. T. A. Early

5. M. L. Ebers

6. R. H. Ketelle

7-9. D. M. Matteo

10. J. A. Mortimore

11-12. P. T. Owen

13. P. A. Schrandt

14. M. M. Stevens

15. P. S. Wood

16-18. ORNL ER Document Management Center

19. ORNL Patent Section

20-22. Central ER Document Management Center

23. Laboratory Records Department

24. Central Research Library

25. Office of Assistant Manager for Energy Research and Development, DOE Oak Ridge Operations Office, P.O. Box 2001, Oak Ridge, TN 37831-8600

26-27. Office of Scientific and Technical Information, P.O. Box 62, Oak Ridge, TN 37831 